\title{
A STUDY OF HIGHWAY TRANSPORTATION IN INDIANA
}

JAN. 1958

No. 3

Jomclanghbi

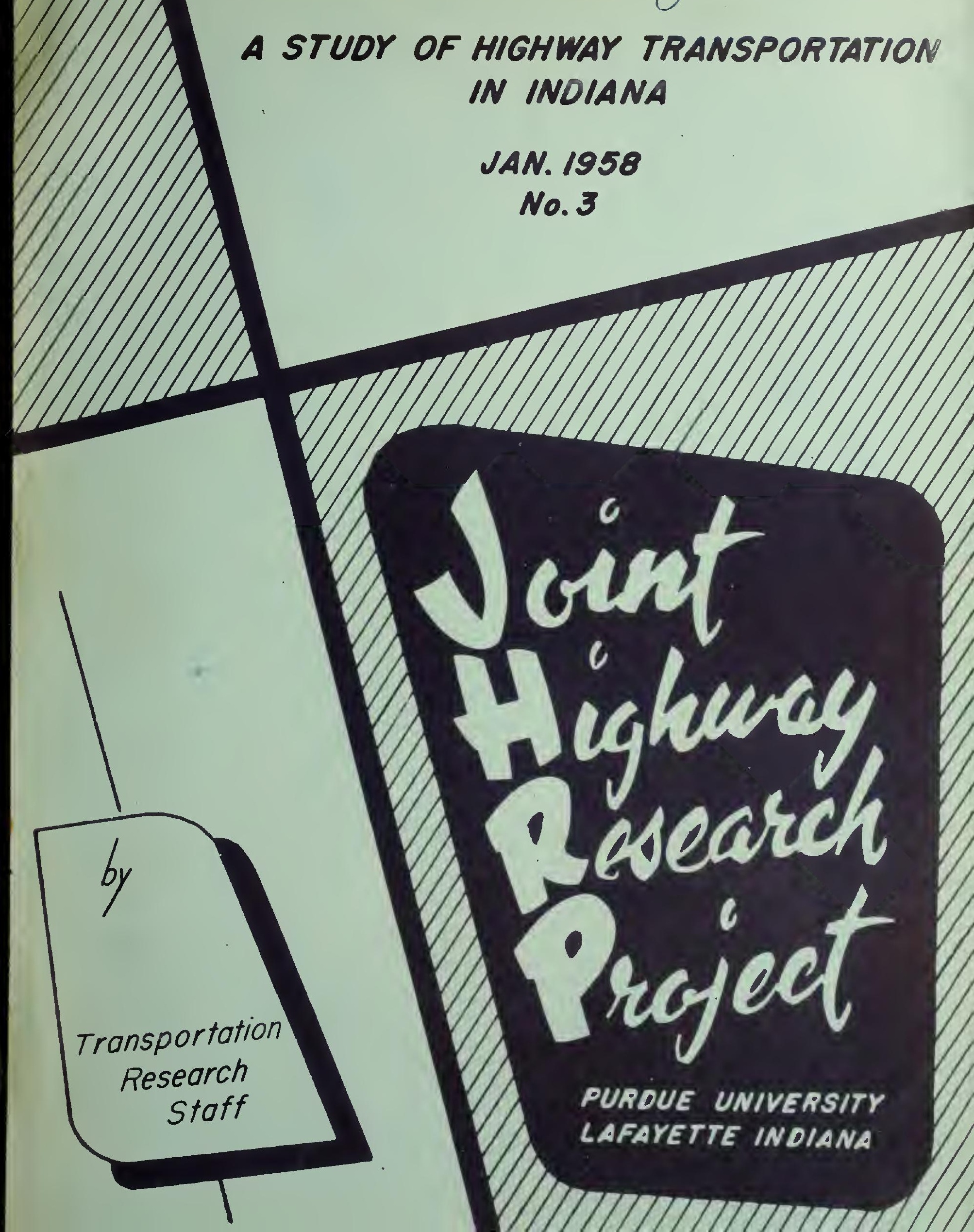




\section{A STUDY OF HIGHAY IRANSPORTATION}

IN INDIANA

$$
\text { by }
$$

Traneportation Recearch Staff Join' Higlwas Rocearch Project

Harolo I. Michael, Assistant Director Artinur K. Branhan, Research Associato Donsild O. Covanlt, Research Enginoer john E. Basmald, Rasearch Englnes: Paul D. Cribbins, Rosecreh Assistant

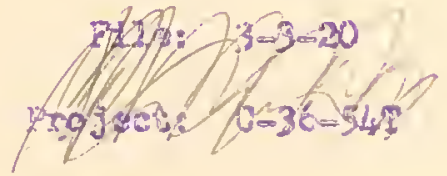


MAELE DF COATHERTS

Folit

SUMARX AID FLNDINGS

EECORHERDITEONS

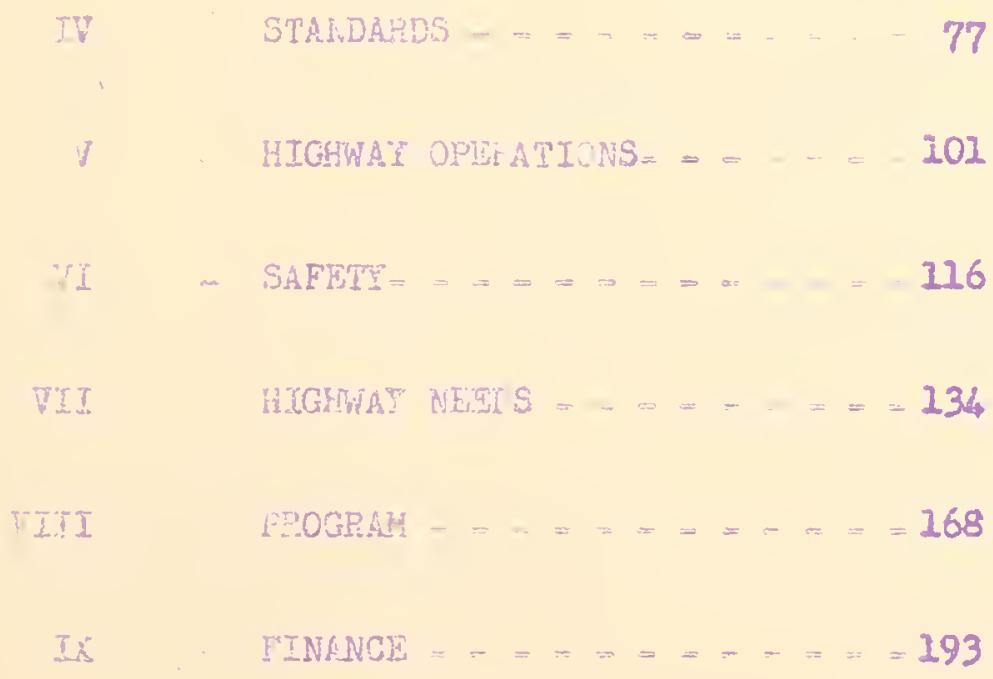

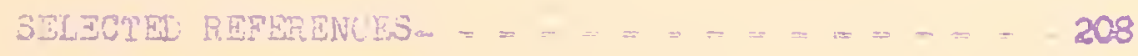


1 Indjana ${ }^{9}:$ Highway troblem

2 Exdsting and Proposed 4-Lane Divdosd Hzghaye 9

3 Indiana limploynent Yercentagee by vccuvation

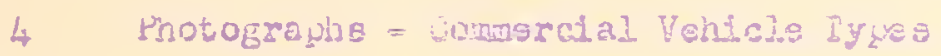

5 Location of loading rroduct a ano findustriag da Indianc

6 Photographs $=$ Tracring of Connoddtiek

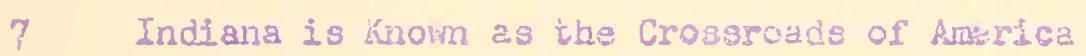

8 Photographg = Hoavy Trucks Haul ilany Tcneilj.13s

9 Livestock Shappod to darket By Trucl Ln 1.955

10 Photogregha o Fecreational and Lidugational \$ravel

11 Photographs = Uae of Highwaye by tarergency Venicles

I2 Thotographs o lige of Highrajs by Sanitition Yehicles

13 Photograghe = Uso of Houge trallerz

14. Photographs o Drive-In Facilitios ano thouping Centers

15 Photograpis = Use of Highway by Industrial Employsee

Ló How Pazsenger Cars are Ueed

27 Seasonal Variation in Traftic Flo:

18 Daily Vamations in Mrafie Flow

19 Photograph = Feak-Hour Congeation

20 Howrly Variations in Traffic Flow

21 Flow of Traffe on Siate Higrwsy Systam

23 Growth of Factors Affecting Travel on Indiana'g Highteys 


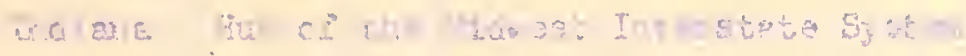

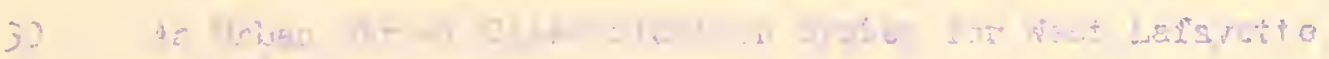
andicon 72

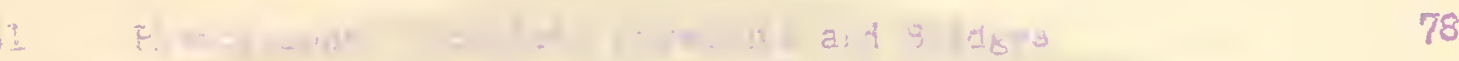

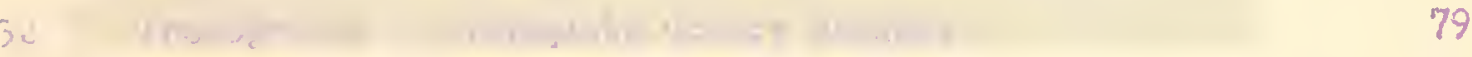

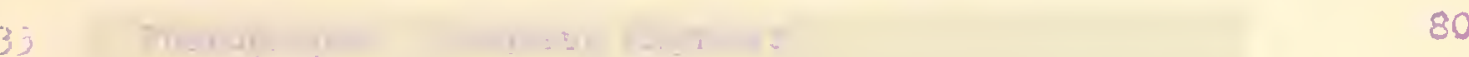

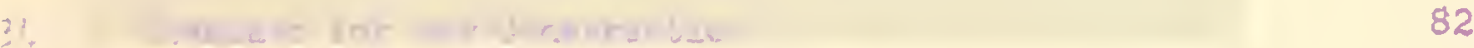

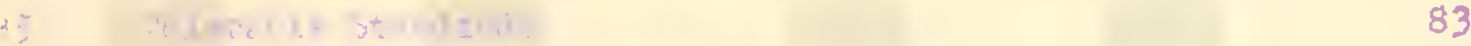

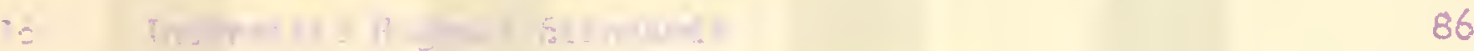

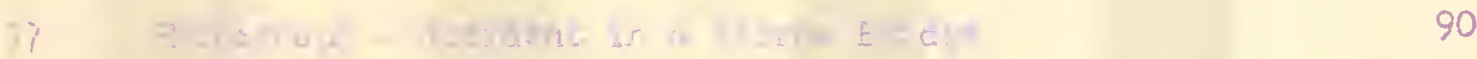

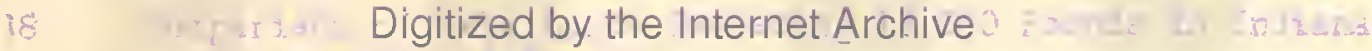
t. the - in 2011 with funding from

LYRASIS members and Sloan Foundation; Indiana Department of Transportationxc
40
Chot xt: : . .

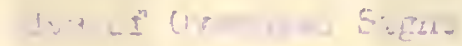
42
Fnstogmenth

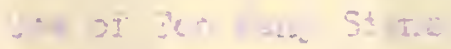
t?
43
Apol16ation:

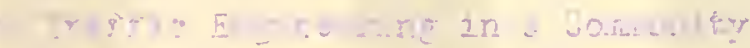
Fis t-wgraph
$M+x+x^{2}$

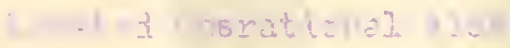
$4+$

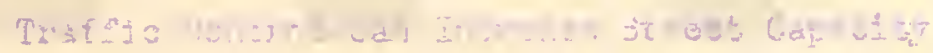
45

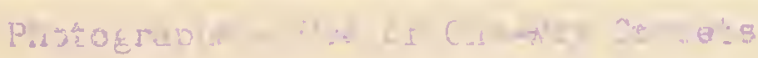

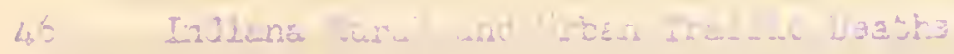

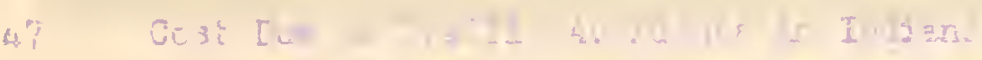

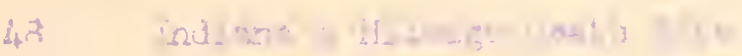

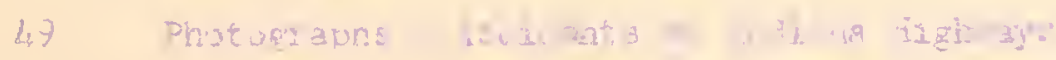

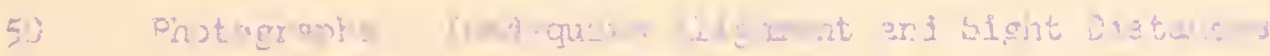

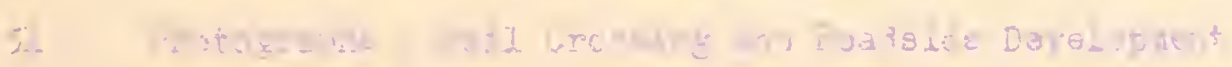

102

204

110

$21]$

112

273

117 
52 Photograph $=$ Driver Training Ln High Schools

53 Photograph o Nagd for Treffic Enforamant

54 Photographs $=$ Accidents

55 A complete M1leoby-Mi1e Inventory of State Highsay Needs

56 Existing and Propogal Interitato HIghwayo

57 Irmediate Needs on the Prirasry and Seconcary State System

58 bane Divldod Highwaya Neadod Now for Pringry and Secondary Syst wn

59 Future Naeds on the Indiand State Syet, ex

60 Photograph - Cloverleai Interchange

61 Photograph - Renowal of Pavemant Markings

62 Annug], Average Coat for 15 maer Program

63 Photograph - Highway Eottlenock

64 Photograph - Adequate Off-Streat Parking Factifites

65 Revenues From Major Highway User Taxea

66 Major Sources of Highay Revenue

67 Construetion and Maintenence Expendituras for Indiana Highwesy

68 Purchesing Power of the HIghway Construction Doller 204

69 Fatimated Rsvenuss and Needs 
Tablo No.

I Classified Hileage on State, County, and City Systems

2 Typical Construction Standards for Rural Intergtate Highways

3 Typical Construction Standards for Rural Primary Highways

4 Typleal Construction Standards for County Highrays

5 Tolerable Standards for County Highways

6 Size and Weight Limitationg of Hotor Vehicles

7 Interstato System lifleages and Costs

8 Prosent Deficlencies and Costs of Improvemants on Rural State Highnas

9 Types of Present Deficiencles on Rurel State Hightrys

10 Typos of Present Construction Needed on Rural State Highweys

11 Future Deficiencies on Rural State Highways for a 15-1ear Program

12 Types of Future Construction Needed and Costs on Hural State Highwys for a 15-lear Program

13 Present Deficiencies and Costs of Improvernents on Urban State Highrage

14. Types of Present Deficiencies on Urban State Highnays

15 Types of Present Construction Needed and Costs on Urban State Highnorys

16 Future Deficiencies and Costs on Urban State Highrays for a 15-Year Program

Types of Future Construction Heeded and Costs on Urban Stato Highways for a 15-Year Program

19 Types of Present Deficiencies on Arterial Streets

20 Types of Present Construction Needed and Costs on Arterial Stroets

21 Types of Future Deficiencies and Costs on Arterlal Streets 
22 Typo at Futur Construction Hecied on Artorial Strots

23 Proseat and Futuro Improvenonts and Costs an Rsingdontiel Stresto

24. Promat and Futurs Inproveruents and Costs on County Prifasy and Serondary Systoms

25 Presset and Future Improvenente and Costs on County Locai Sarvico System

26. Stophchp and Roplacemsnt Costs por Steto Highmay Syztenam 15-1025 Prograin

17

27 Estrated Anousi Costs Por ing for Adequate state HLghway Haintenance

28 Estlmatod Annual Costa Per MLle for fóoquate County HL gomeg LaLnteancs

29 Eselnated Anmel Costs Far MIIe for Ádequato Cif.y Styeret dointenance

30 Cost of a 15-Yeas Pxogram on tho State HLghray siremsat

31 Coet of a 15-Iear Progkan on the County IHghryg Syatents

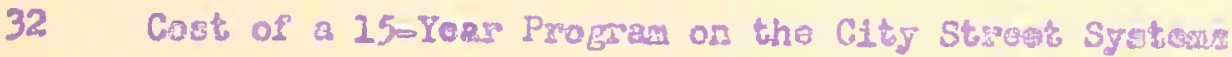
181

33 Present and Future Status of the Istoretste Syacen

34 Prosent and Future Stacts of the Sizto Rusal Primary and Socondary sygtons 


\section{ACKNOWLEDGMENSS}

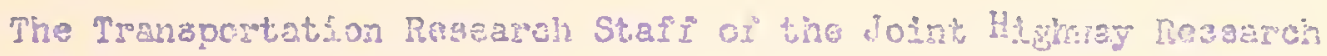

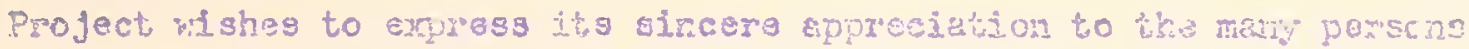

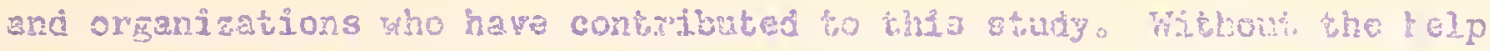

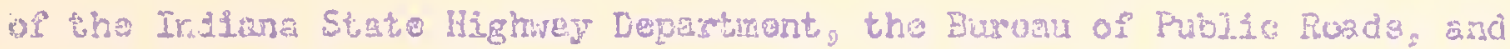

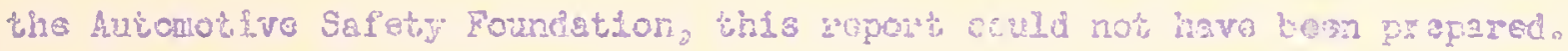

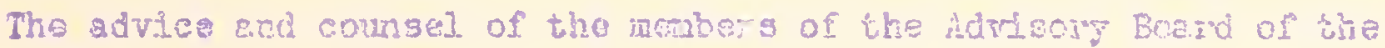

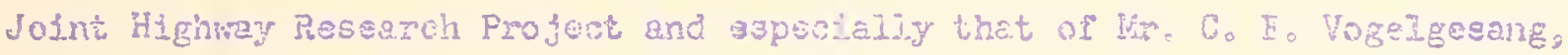

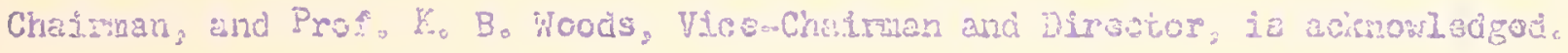

Payricuser thaks are dus the 8 ix Diatriet orfices of the lighway

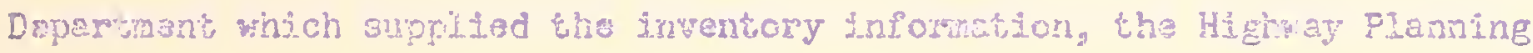

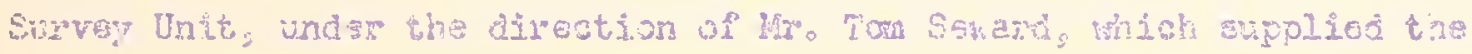

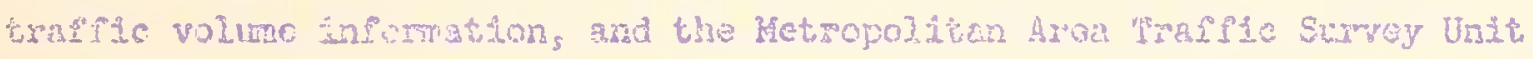
disected by Mir. R. "i. Brokn, rindeh providal juformation on tho Intoratata

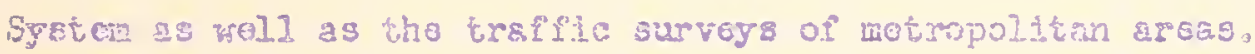

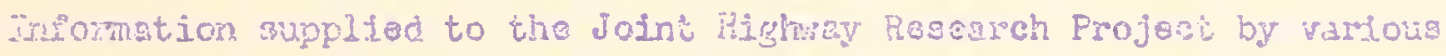

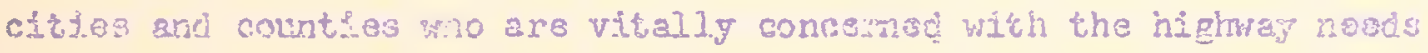

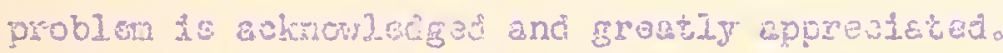

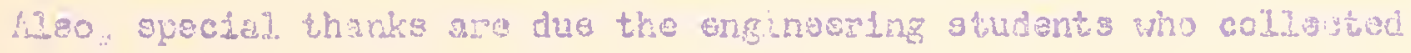

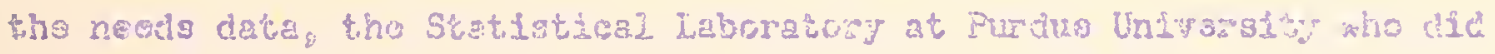
the cemputational kori, and tha tcany part-tino workers who halpoi analyzo trs dist and excute tho graphical prosentation. The following staf fuen

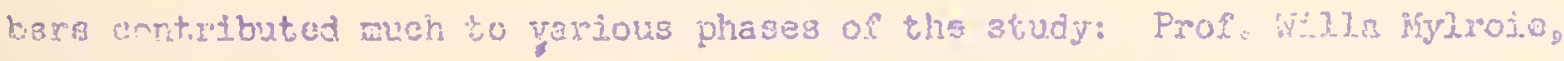

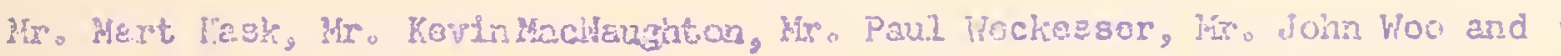

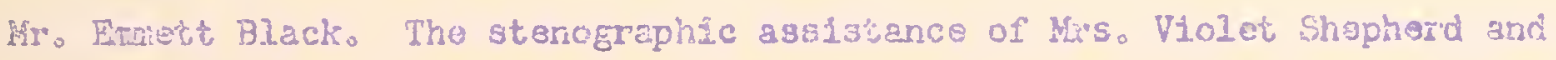


$-v 1 \pm 1-$

tho coding assistance of Mro. Betty Pinkar were Indigponsable. The assistance of other staff menters, many pert tine student workers, end secretaries is also acknowledged. 


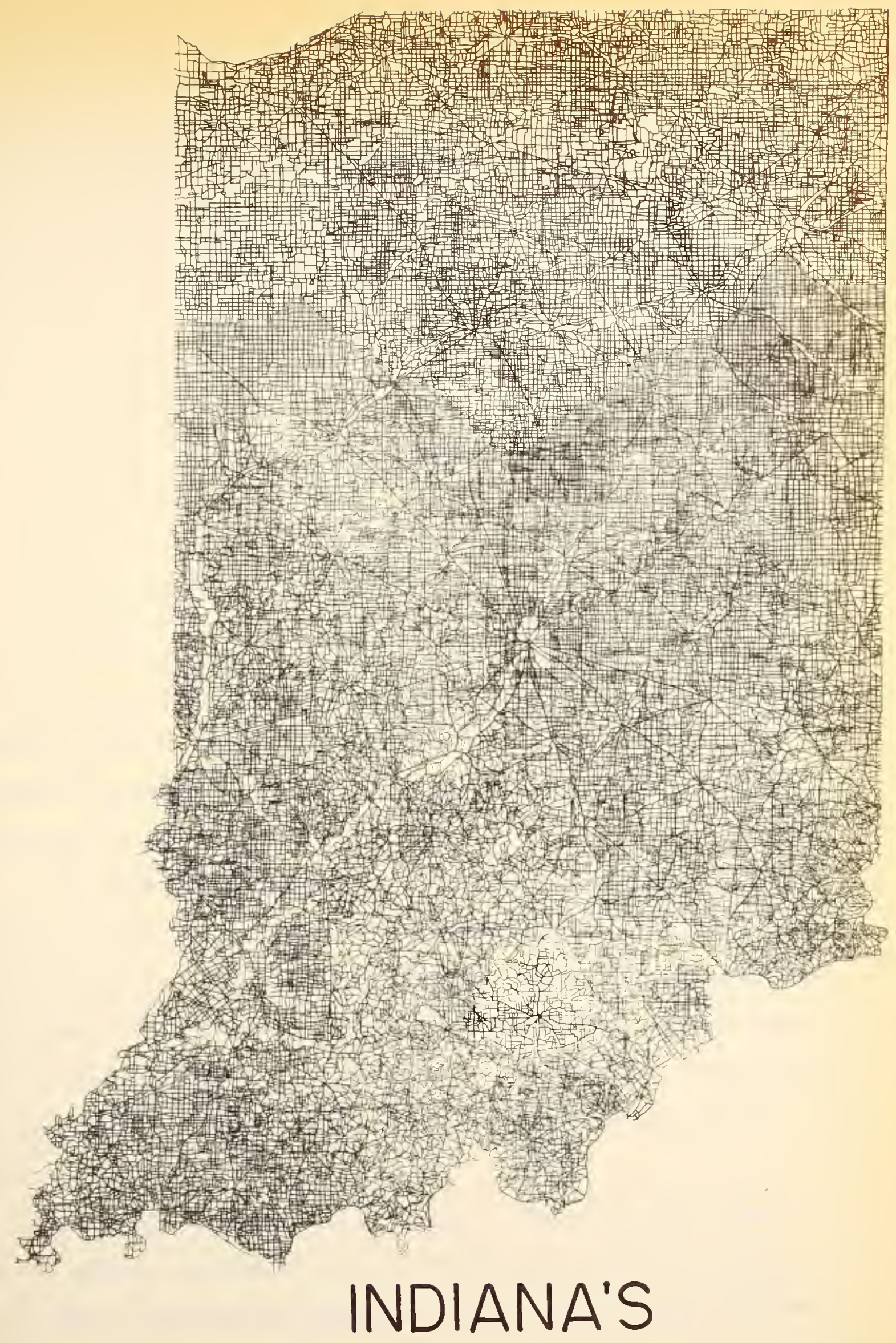

\section{HIGHWAY}

PROBLEM

FIGURE । 
A STUDY OF HICUWAY TRINSPORT $\Lambda$ TON IN IMDINNA

\section{SUDAMRY AHD FINDIMGS}

\section{Tetrodist on}

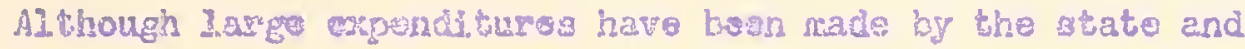
10al govornmeric of Incilana to lmproro highways ior motor vehicle travel, hlginway innoovensat has failed to ksop paco with trafile dwands.

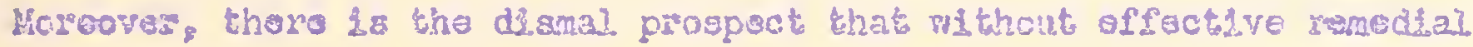

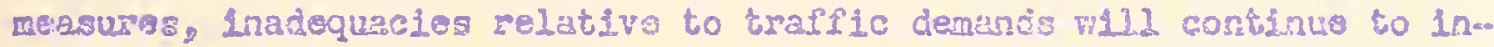
creaso whilo highway travol doubles by 1975.

Th18 ongineering study revoals the cxient and difflculty of tho highuag problems of Indiana. Hore than one-fourth of the road and street mileage is deficient and now requires resurfecing, seconstruction,

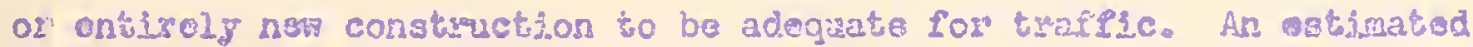
exponditure of $\$ 5.2$ bj11jon 13 necososry to corscet prosent (1957) and futura dofickancles and to provido for malntenanco and adninistration durlag a 15-year pargxan。

Devalopnent or lmprovemsnt of adequats roac and strost systons, horeve:" cannot by achleved by rule of thuxh of by piacemeal legtalation. Thsy are ongingering procesmes and thelr accompliahnont roquires 


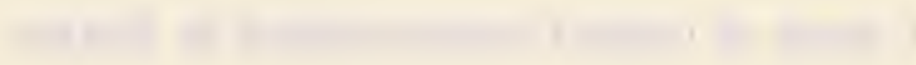

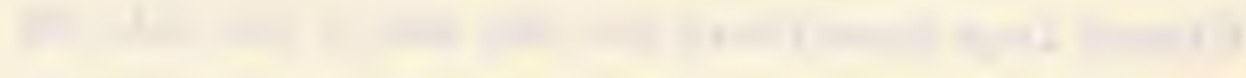

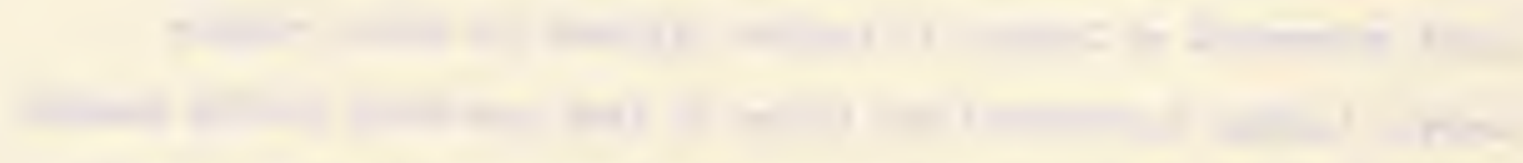

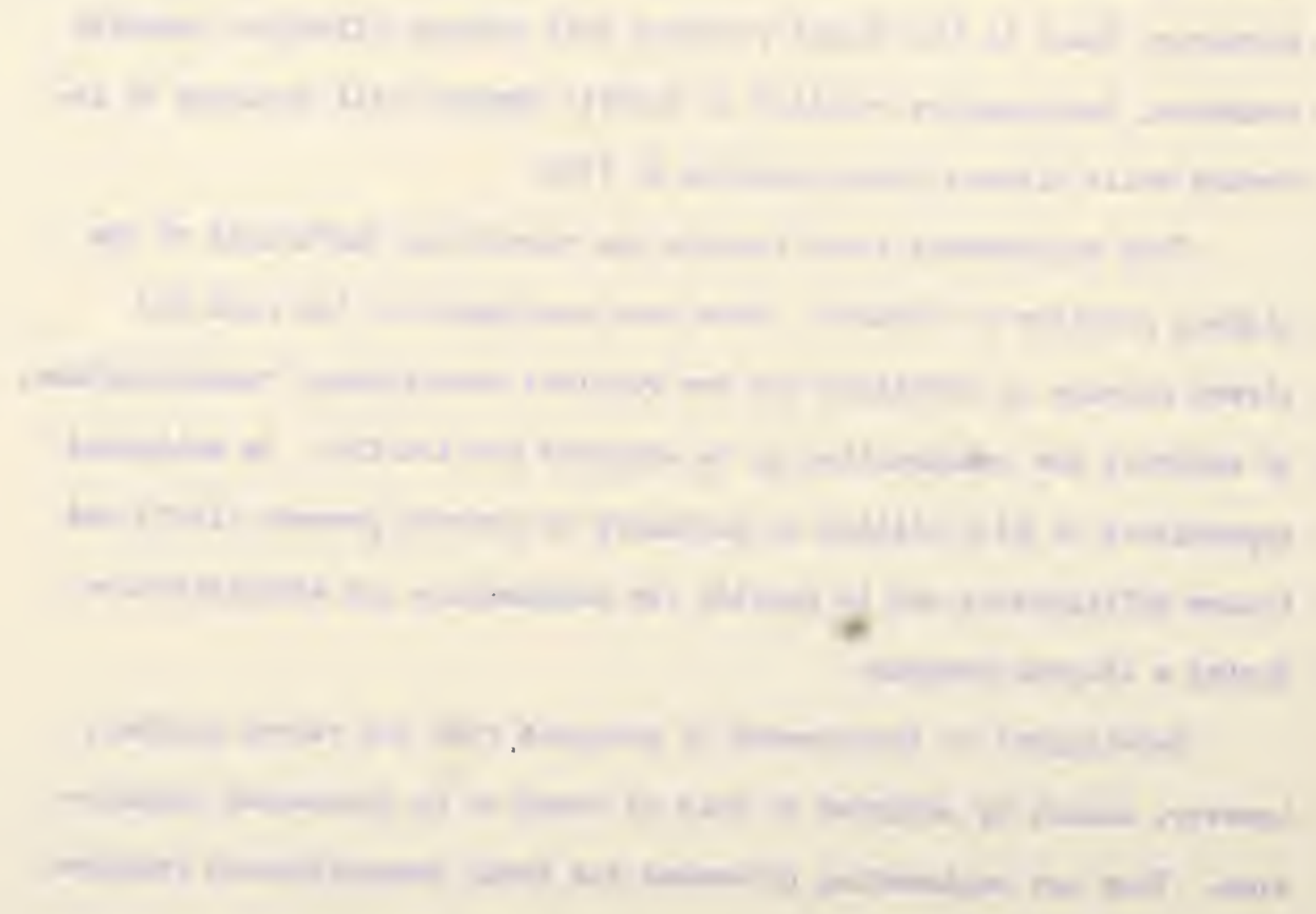


offective and continuous long-range planinge Such planning and operation must bo based on Plm, consistent discigions of coneern to trangrore tation policy, acolntatration, ongineering, and financo.

\section{Econoreic Sezricss}

The growth of the highiag 3ysten has beon intuatoly relat, od to tha social anci econorate prograss of the state. Transportation is recognizat as \& major econouic force and Indiana progress can bo moasurod in teme of the development of mathods used to carty gcods and people from placo to place. In the pas ther has bean a noed for the extensive growth of

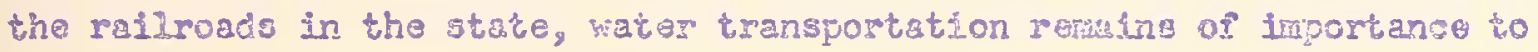
certain gsogrephical areas, and the use of air and pipeline transportation is increasing rapidy. Eut highways, in addition to being esgantial to motor transport in their own right, porform the esgential service of Iinko Ing all other meens of transportation together.

It 19 difficult to measure the influence of highwy trangortation upon state and nstional econony, but great beneift, accrus to agricuiturs,

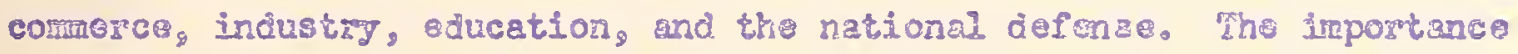
of highweys to Indians is reprsented by the msig vehicle reglatrations, 1.5 million passergor cars and over 300,000 trucis in Indians in 1955 Exeluding farm truokine, about 325,000 persons wero anployed in hightey

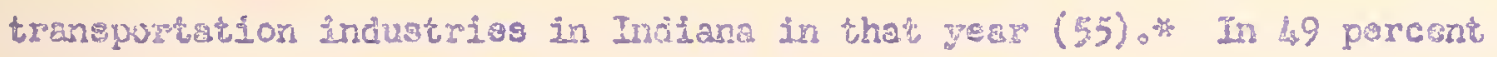
of the state'3 towns and villagea, highrsys are reported to provide the only availabla fraight transportation (55). It was also found by one investigator that every one of the 899 post of fices in the state use soms highway trensportation and 550 depend upon highwey traneportation for sorvice (55)。

Number in parenthesis refer to blbliography. 


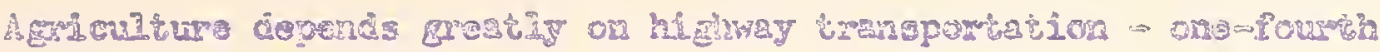

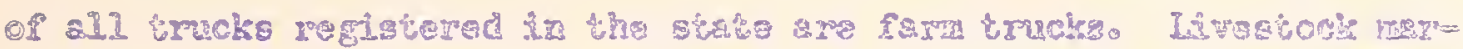

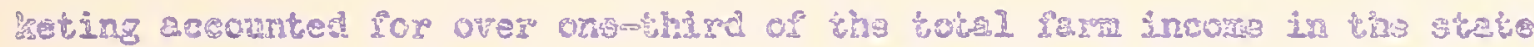

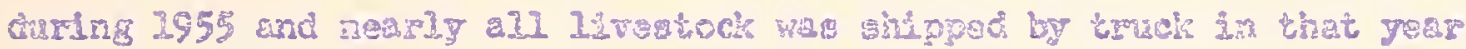

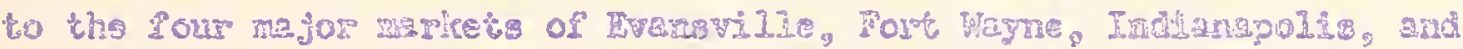

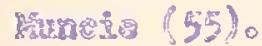

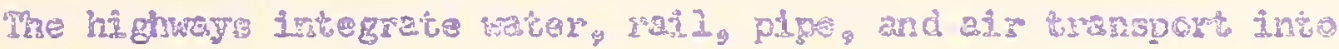

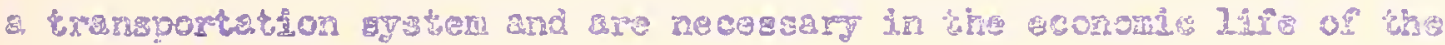

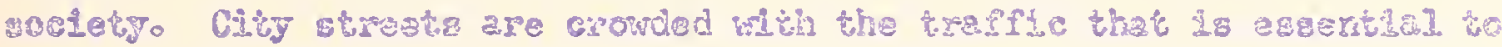

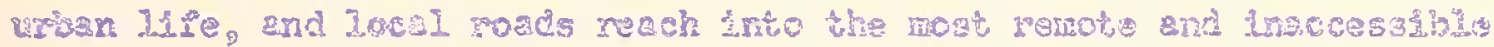

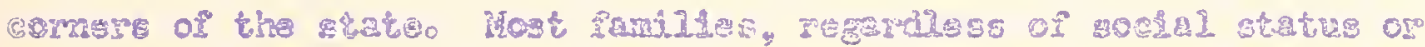

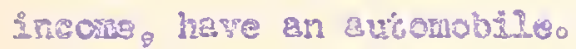

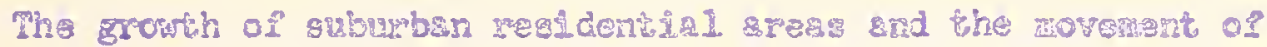

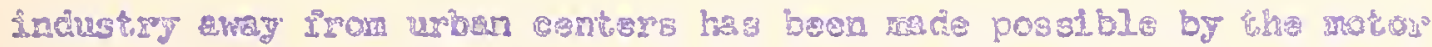

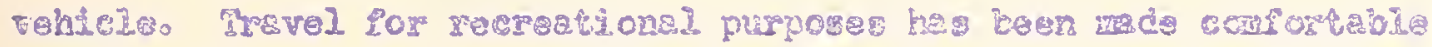

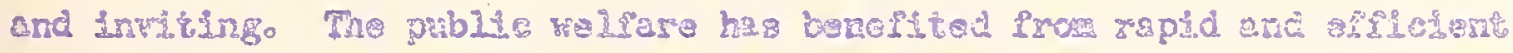

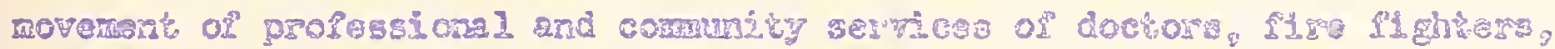

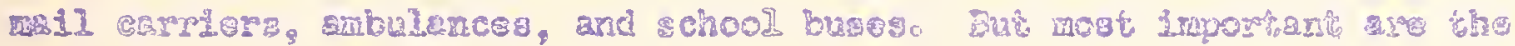

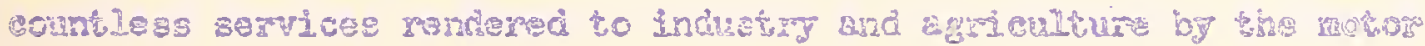

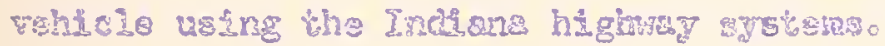

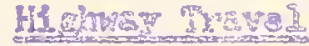

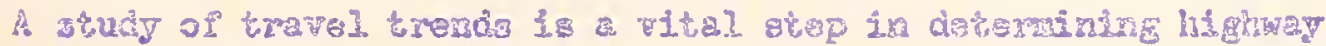

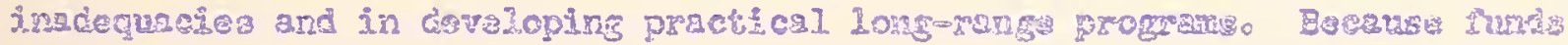

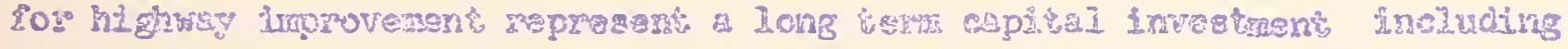

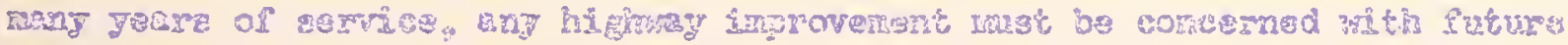
domancis: 


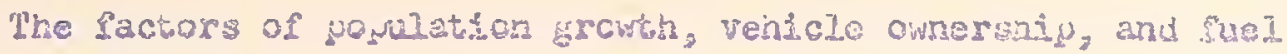

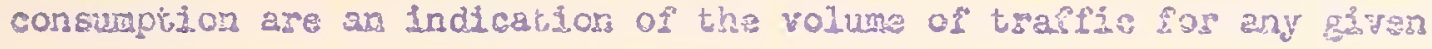
geriods By wudying these pariables, it is possible to nabe a reasonably acourato projection of treflie rolure Such pajectionz or estimateg, 21 coundy made, show now wuch traffic mey be gxpocted in

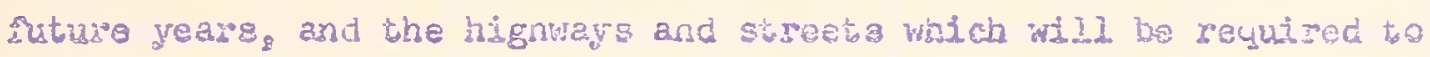
serve and accomodate the trefizon

The 1950 consus reported nearif four million persons in this stato, and it is eatimated that wne pupulation will apprach siz nfilion in 1975. Although notor vahicle segistrations Ln Indians docreased chring the deprossion and horId War If they ircreased from 875,000 in 1930 to neariy $\mathrm{J}_{8} 800,000$ in 1955. The per capita otrorship of the rotor rehichs changed fron 3.7 pereans par vehiche In 1935 to 2.25 pergons per vericle in 1955 and to is exoctod to spproad 1.35 perscns per vehicle by 2975. Listlutes baged on analyo sis of motor vehicle use and fuel data indicats that ting aysage

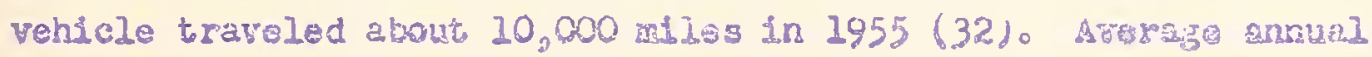
traval appears to be levaling off st about thie milatge fonserveliw projoctione of these baste factori of trafile teneration indicats that in 1975 highway traffic in sndiana wil1 be epjyoximistaly double that of 1955 .

\section{Highray Ciassification}

The purpose of long-range hi ghway planning is to develop roede and gtioets which supply the anourt and type of semilce denindied from

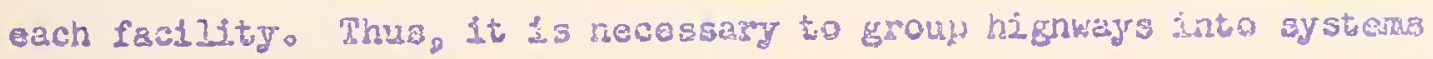
with all highways in a syst,om performing ofmilar gerices, to ageign 
lasponsibility for their imorovenent to the unit of governonts most concemed, and to derelop an overall. financing plan fitted to the requirements of each systom. when state, county, and city hijhway adninstratore are ragponsible for construction and malutenance of excessive mileages of highways inappropriatedy asughed to them, efficiency in management and fund expenditure is difficult to maintajn。 We of the most basic steja in the propar and efficient adninis= tration or the highway systens is adequate classification. In Indiaub, many of the county and city hichways require classification and the state hi ghway systems would benefit from a reclassification.

\section{Standurds}

In this study some sub-standard cunstruction was found on all road and street gystems. In some cases, deficiencies in strictural design contributed afgnificantly to the rapid deterioration or obsolegs cence of payements and bridges. In others the lack of control of accosa was of major importance. Highways cannot be changed us readily Es automobises by changing nodels. Phey must be constructed to siando ards which are adequate for the present and future denands of traffic。

\section{Highway Uparationg}

The efficisncy of operation of inany miles of hignway could be increased through effective use of trafic engineering yrocedures.

One-way operation and renoval of parking vild increase the cepacity of many city strets. Progressive timing of signais may permit free-flowing and unimpeded movewent of traffic. Furinerwore, the developinent of new nighways requires une coordination of planning and design with operational characteristics and reciuiramentso 


\section{Safety}

In 1955, highway traffic accidents in Indiana claimed the lives of 1,145 persons -258 in urban areas and 387 in mural areas (42). In addition, over 37,000 persons were injured (42). The total economic los3 for these accidents including the loss of wages, medical expenses. cost of insurance, and property demage exceeded il $_{4} 0$ milion $(42)$. The traffic fatality rate in Indjana was 6.0 deaths per 100 milion vehicle miles as compared to a national ifgure of 6.4 (42).

Elimination of the inadequate elements on the highwayz of Indians will reduce accidents. Some estimates indicate that 40 percent of aII accidents could be eliminated if the highway systens were inproved to modern design conceptso Control of access on the Interstate and Primary State Highways will account for most of this reduction, for Indiscriminate roadside development has caused many gectiong of higho way to develop high accident rates.

The highway safety problem is indeed difflcult. No one solution for it can be obtained, and man, with his human Iimitations, will always have accidents。 wach can be done, however, to prevent rany from occurring through adequate engineering, education, and snforce ment。

\section{Needed Highway Improvements}

\section{State System}

With the notable exception of the toll road, Indiana has very few miles on the $1,100-m$ mile Interstate System which meet modern minimum design standards. Nearly 936 miles of this system must be 
newly constructed of reconstincted. Many of the fourolane dirded highways on this system unst be relocated of rebuilt, promarily becruse of lack of conitrolled access. All two-line highwiss on this gyaton nust be rebalit and many of when relocated for econumic reasoriso The Injtial construction costs for the Intorstate Sygtem w11 require an expenditure of $\$ 783$ ratilion in rural areas and 274 widion in urban areas. The frevay sysich in Indianapolis alone vilid use arer onemalf of the total urban expendiures for the Intergtate syaten In Indians.

More than 2,800 miles of the rural yodnary and Secondary wystems

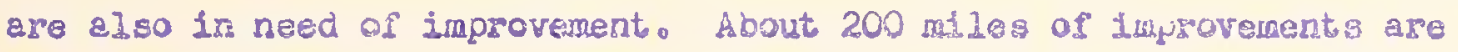
required because of inadequate capacity and an additionid 2,400 raidez bocause of structural deficlencies. Neasly 1,300 structurea should be replaced or widened. Over 450 atlos of now four=lane divided higho ways are now required on the Prinary syaten. The tolal esthuated cost to elininate present deficlencies is 72 willon. The cort of $x e-$ const zruction of highways and structuses 1 n neagly 85 percent at the total and the remining 3.5 percenc of the cost is for widening and resurfacingo The cost of now utructures is 28 percent of the total cost of eliminating all present inadequacies on ting rairang and Saccindary Syster.

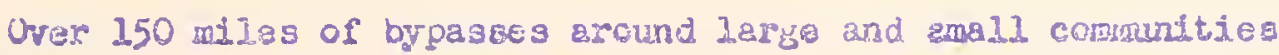

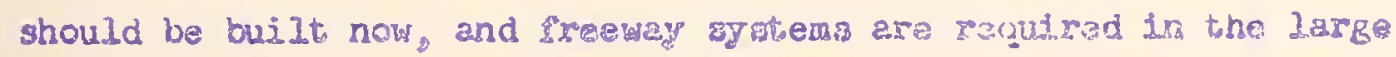
citieg of the state. The total cort of the limediately meeded infroves mants on the State Urban Sygtem is 202 milion. The cost of providing offostreet parking Iots and parking tarages hag not beer iucluded in this estinate. The parking problem, however, must bo considered with 
the highray problem if en adequate and lasting golution s. 3 to be ettained。

The Improvements required on the state gystans during the aext flfeen years will be of ceasiderable mignitude. wer 6, lub anles

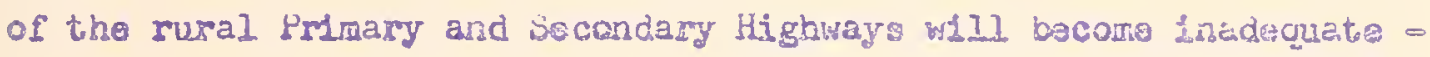
600 miles will be caused by lack of capacitys 5,000 allos by struchrad deficiencies, and 500 miles by a combination of capacity and struetural dericiencies. It will be necessary to rebuild over 1,000 bridieso Nearly I, 150 miles of four-lane divided highway are reculured and 1,400 miles of two=lane highway musc be rebuilt. Almost 3,600 mises of widaning and rosurfacing will bo needed. The total cost oì tinjo work including the raquired structures is fign mildion, of which 77 percents of the cost is for reconstruction and 23 parcent for resur fasing and widening.

On the Stato Urber Syatom mäng addithonal mi.les of by pesBse will be required in the next 15 years and nost of this juprovenent should be fouralane divided construction. However, the rost convlex. proilems will remain on the routes that pass directy throush the cities。 on a njleage basis at least 40 parcent of future urban oeflciencies will bo caused by inadequato capacity, and about 49 perco

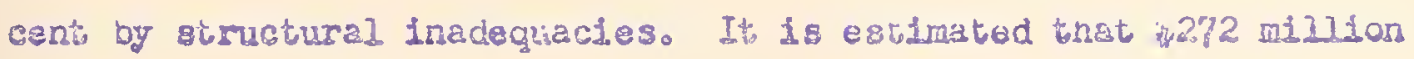
will be required to eliminate the urban deficleacies on state routos which will accrus in tne nest fifteen years.

In addition to the construction alroedy discussed, it will bo necessary to provide additional fundo to adequately mintain the eno toire Systom. Although the Syatem will be continually inproved, the 


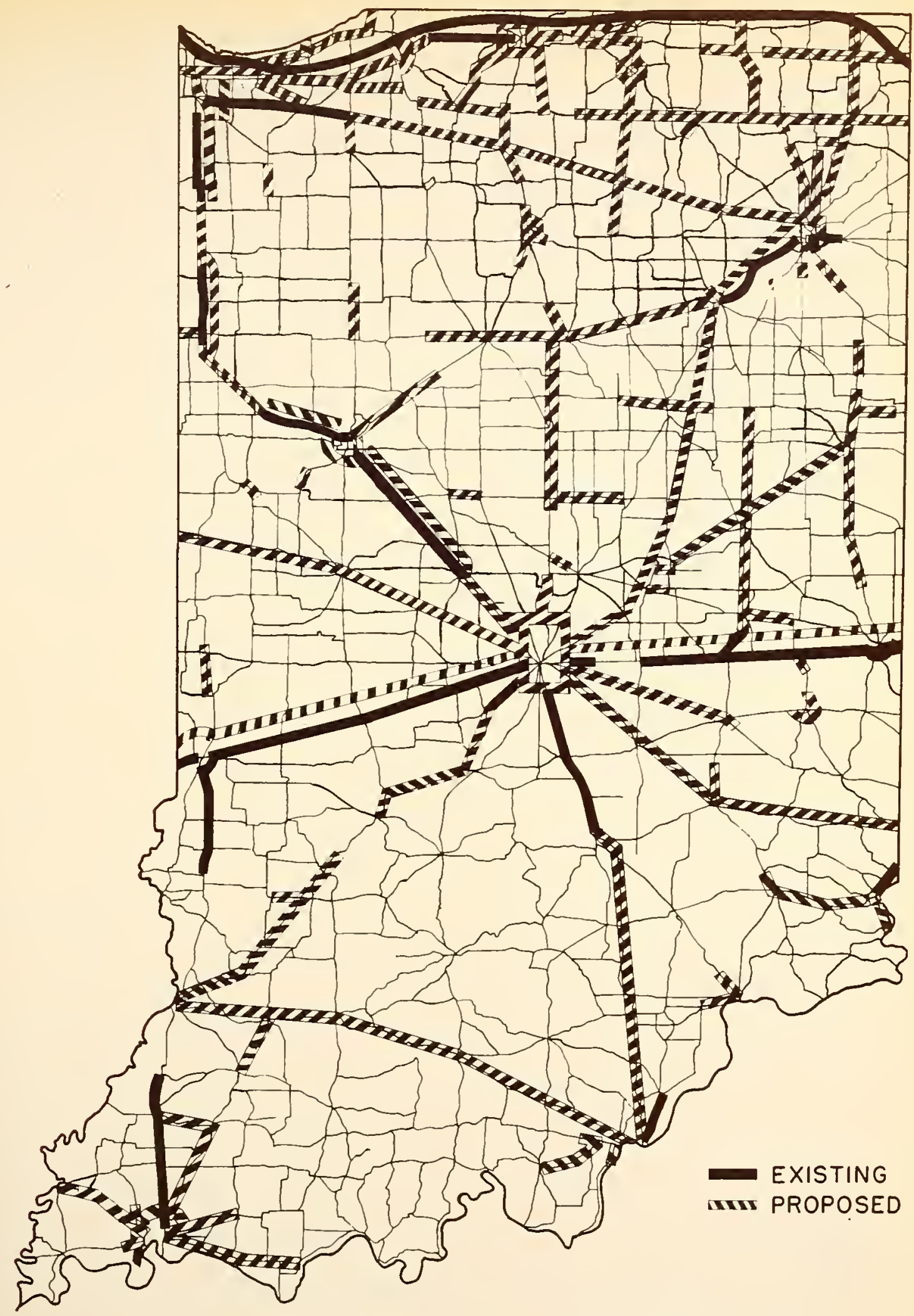

EXISTING \& PROPOSED

4 LANE DIVIDED HIGHWAYS 
maintenance costs will remain almost constant. Lmprovec hifbways havo lower maintonance costs for the oane traficic volume, but tris roduction 1.5 offeot by the higher total cost resulting iron s greater number of wilss of fourolane divided pavernont and lncreasec traffic. It 19 estimated that on the State Primary, Secondum, and Urbas Systems 354 milion should bo spent for maintenence, Including adninistration, in the next 15 yearso

\section{County Rosd Systom.}

The countiee graatest problems are on the Frinary and Secondary Systers. In this study, nearly 21,000 miles were estinated to bo in these Systome and the remaining 55,500 In the Local Service System。 In order to elinfnate the jresent deficiencies and these that wi11 accrue in the noxt 15 years, construction expraditureg of $\$ 372$ million on the Primary and Secondary Systems and fl61 miluition on the

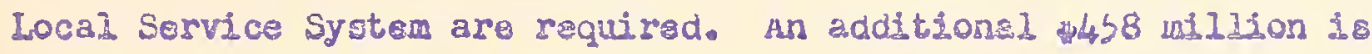
required for maintenance on all gystems.

\section{City Streets}

It was arcesagry to estimate tine milsoges of olreets in the various classifications in wang citios where deflued classified systems did not anst. A total of 2,600 miles were classified as city arterisls, and 8,600 miles \&s residential streets in this study。 During the next 15 yoars, nearly $1_{8}, 000$ iniles of tre arterial sygtem and over 5,100 miles of the residential atreet systam must be reconstructed or racurfaced. Ihis will cost nsardy 237 mill1un for con= gtruction on the arteriai street system and 207 million on the 


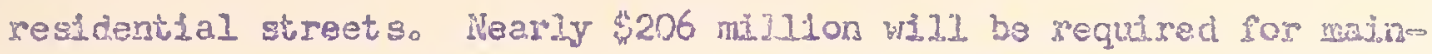
tenance of both systems.

\section{Program}

A pariod of 15 years wag solected for this study as the optinum time iequired to eliminate all highrey deficiencies in Indiana The annual average cost for a $15-y e a r$ program to bring ald of sho high= was and sireets of Indiana to adequacy is estimated to ks:

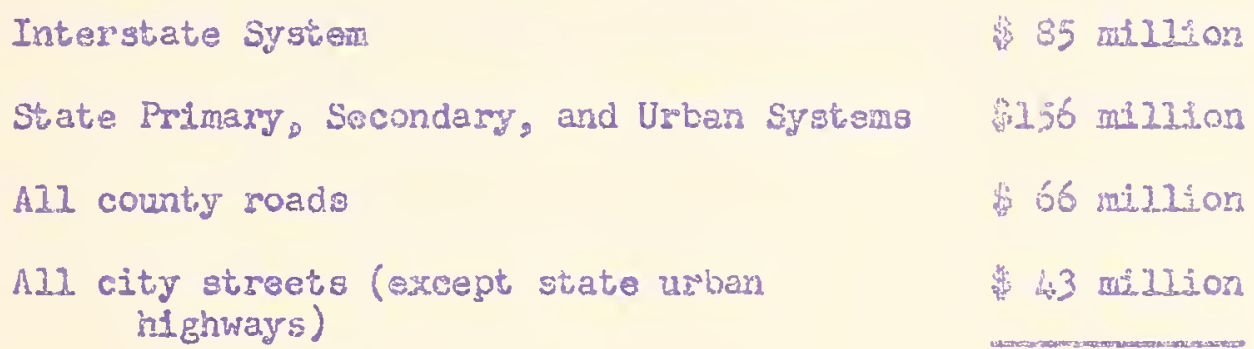

Total average annual cost for 15 jears

3350 mij]

\section{Finence}

The ebility of Indiana to bring jto highways to an adequato status $2 \mathrm{~s}$ depondent upon the money avalable. Funda are prailable from three sources - the Hotor Vehicle Highway Accourt, which derfwes its monies from motor fued taxes and licence and registrat,ion pees; local monies derived from proporiy taration: and Federal Atd (75)。

Highway funde are apent for three egsatial highray functionsconstruction, maintenence, and adrinistration. Frpenditures for the state oystem have bsen primarily for construction, and the expend itures for county roads and aty gtreots have been primarily for makntenance. 
Sirce 1939 costs of highway work have risgn because of econolic conditiong. fiscording to the hivhus construction cost indar de=

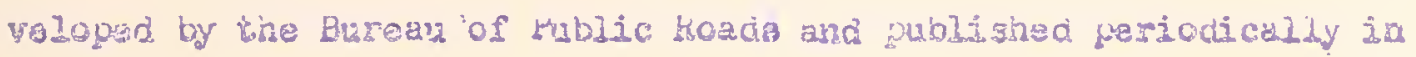
mumaroue technicai nagatneg the 1955 highway doldas puranased ondy 79 parcent as nuch as in 1946 and only about hasf as man as it did Ln 2932.

Other conditions of major importance affect the cost of higho Way construction. Standards of histusy construction have risen, grd It is probable that they will continue to rise. protection of the highway lavestmeat tnough adequate limtod acsess will have a parnownced influonce on preventing functional obsolescence and is econow Lcally sound but it will also increase tre dnithil costo

The general trend in highwy fanance is for the ufhiday user. through vahicie and motor fuel taxe $3_{y}$ to provide jucreasing amounts of zevenue for highway construction and majuemance. In 1955 and exciuding Federal Add, the highway uger provided rearly 85 parcont

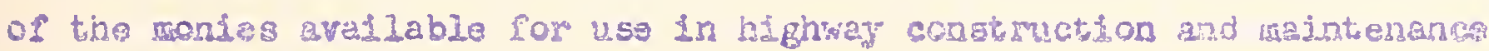
programs in Indians (64).

The pas3iso of the Fodered Ald Act of 1956 and the Lncrass

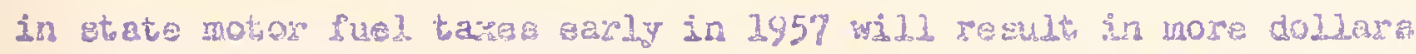

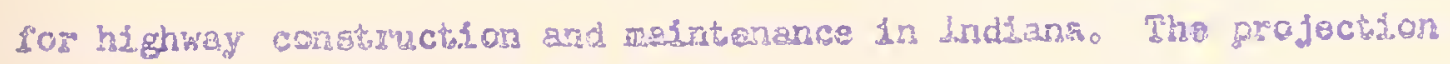
of all highway revenues, to bo oxpested from facel pollcies in effect 1Is 1957, howeterg, Ladicates thet gufficient funds wi.l工 not bo oraflable to eliminate all of the inadecuocies of the highray of Indiana within $15-y$ ara. 
AE a rosut of thia study of the highwys of Indianag the

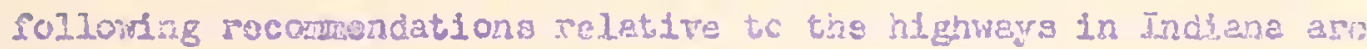
nacida:

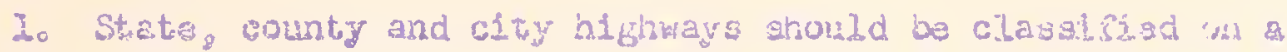

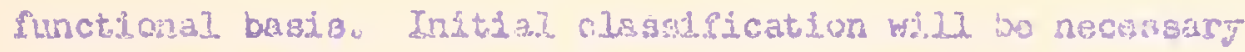
for most clty and county hirnways anamuch as mode of these juriedictions hare never complately frcupen thois hientays Lnto Byetomo In inost farkedictions whorg \& 11 hitghay have been classiffed, a Led. The ond result should be as intogreted netwers of stateg county, and city highway3. Desiobio mileage limitoticng should be egtablished for mejor classifications and auth= orfation to change the classiflcation of a road as costitions wariant should bo cased on establishec critexia.

2. Munimun design gtandards for nev laghkey fac anties should

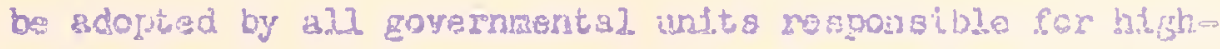
rey congtouction. Thay shoul.d be basad on tha bost aruznerw

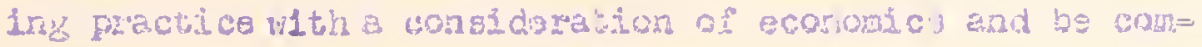

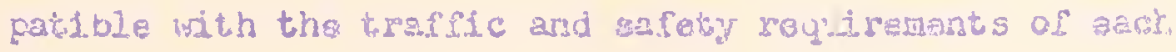
highway bysten.

3. The present Innted eccess lak should be appuied roboruis by where applicable to protert iajos state highwajs Irom wre

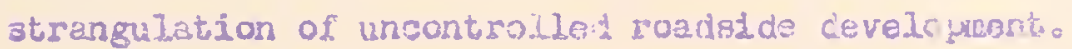


40 The highway planning and traffic engineering activitieg of the State Hifhway Departrent should be integrated ard Guxpanded.

5. A progran for developing effective city $=$ county $=$ state relations should bs enconraged to faclitito the plan ning, construction, and opsration of all hightors in Indiana.

6. Most of the chties of Iraliana should secura roltef from many of their traffic problems atromgh the appication of the poinciples of treffic onginesotng. Additional grali= fled peationns. and adequate bugdgets are required in this

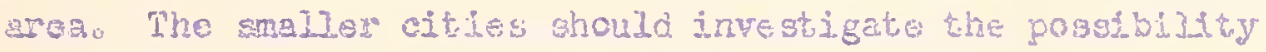
of securing the partutine services of an exprtinced trafic Brginger to assitst, them。

7. The services of englneering pergonned are badiy neadad in the countses to plan, construct, opsrate, and anathin tizesr highway syotans. Eapacially reeded fos county roads is

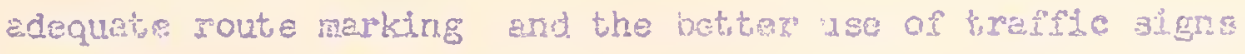
and rarkinga to limprove arrylce and safoty

8. The agaesstve highway saraty edueation progian in Indiars should be continued and expanded to snciude noro enphasis or the local lavelo Driser educston programs shoulo be Bxparded to include all htgh schoolso 
9. Hayg cithes chould study their traffe laws and bring ther into agreement whth the kodel Traffic oroirsnes and state regilabjonso

10. Fach county and city shculc tnitiato and majniain en arcident, record system accorting to hnîform procedures. These records should then te analyzed and used to dovelop a jocal accidert reduction prograin.

11. Eacin governmental unit in Indias should prepare 2 lomg-

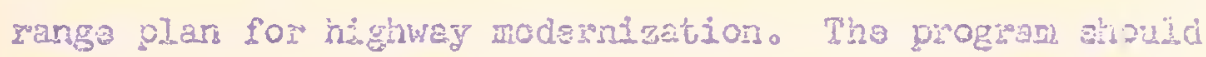
utiline s sound rethod for sabablishing priorities of construetiors.

12. A f1seal polfcy that kil provide adequate ince to suecessuly complote the authorisod longcyange plan should be studfed and egroed to by eech goverratental unito

13. An inverbory of highway conditions should be maintained Ln a current status by the State Highway Deperthant anc the counties and sitis of Indicne. 


\section{Background informant 0 m}

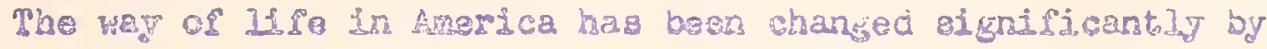
the developnent of the autanobile and by the daprovement of the rad and street syatems. The nation, os woll do every state, city, and

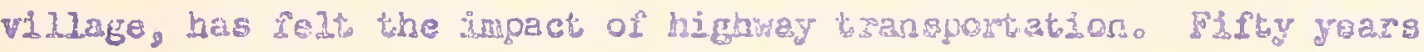

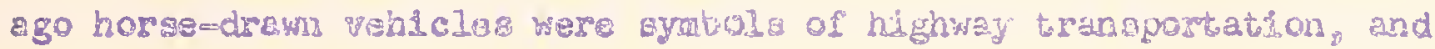
conmunty life was centered around the genorat gore, the church, and the lit.t. 5od school house kish compunty, an some, was Eoparats and isolated from its reighoor.

Fifty yearg gigo highwy motod Pehieles wero \& curlostty and a

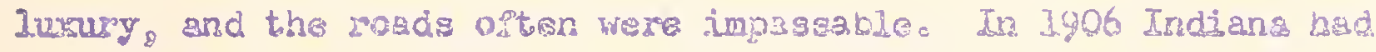

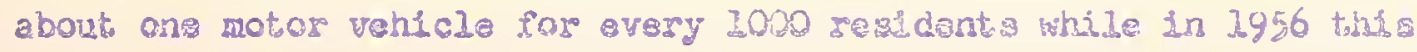

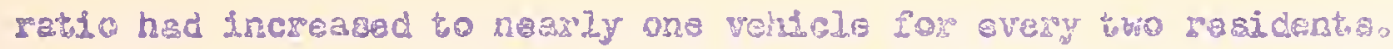

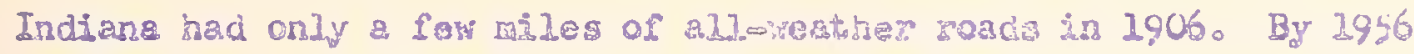
over 90 percent of the road milasge was in thin ciasaification, but a large percontagh of this mileage was juadequete for present and futare tระfาเc $(36)$ 。

The Lnedsquey of the Indsane dighway Sygtas today La tha Mosult of four bs

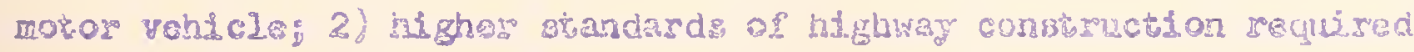
for she preacht motor vehicle; 3) fatlure to provide the necesiary funds for consiruction, recongtruction, and matntenance; and 4) the decroasd

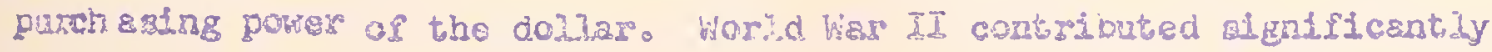

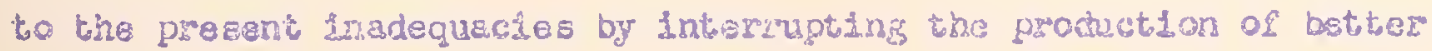
rords. Construetion and mastenance during the verot minimun neods 


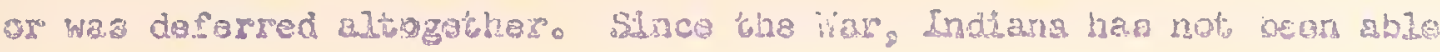

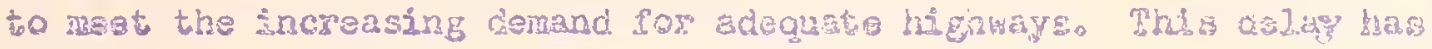

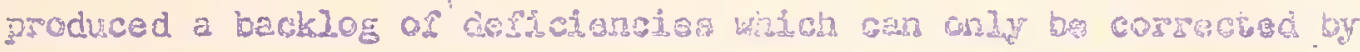

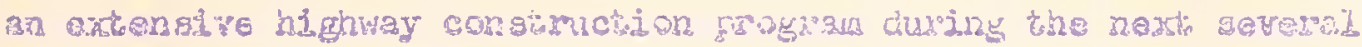
7oar:。

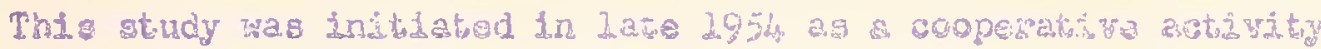

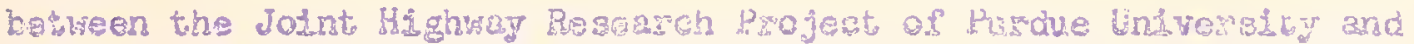

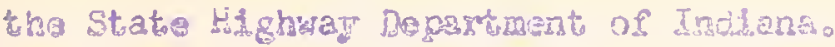

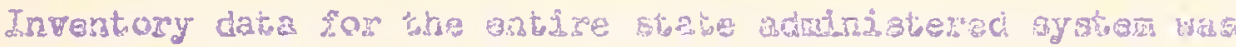

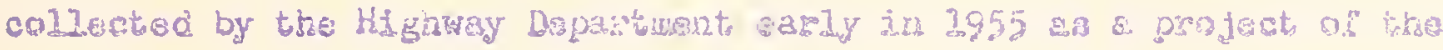

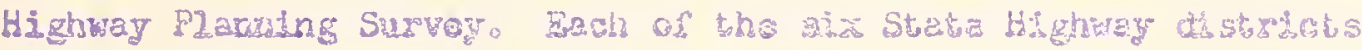

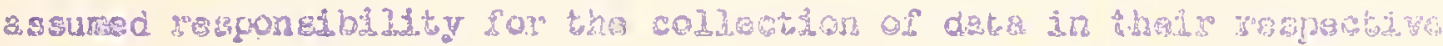
8xєaso

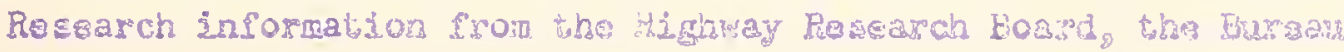

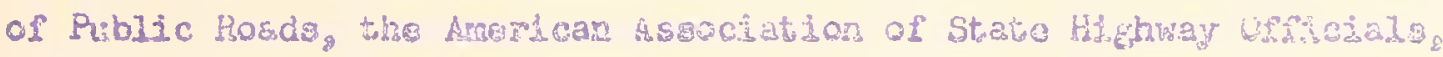
and the Autorative Safesp Foundation contributed to the studyo Tha

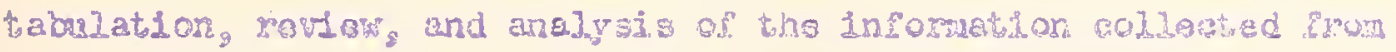
tho several goures, ar

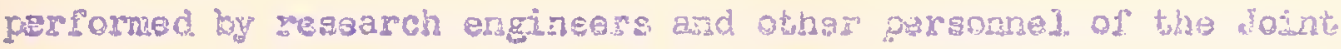

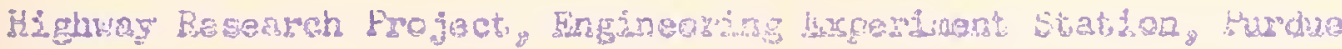

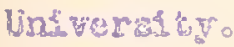

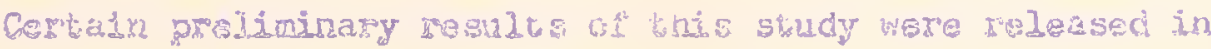

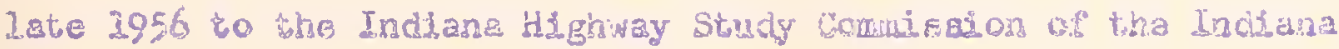

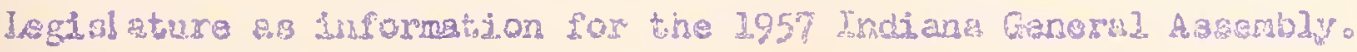




\section{Segpe af Sindy}

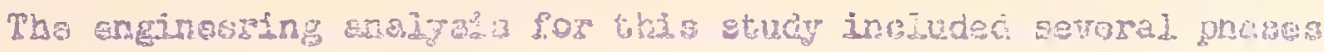

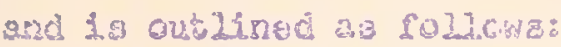

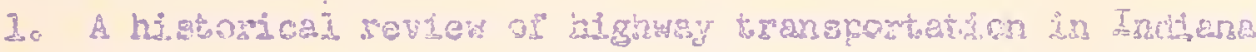

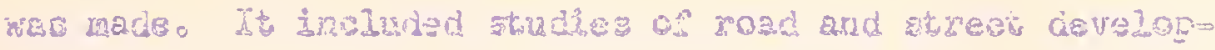

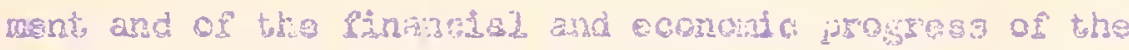
high:sy aystict:

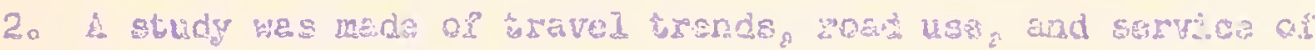

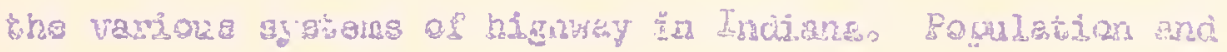

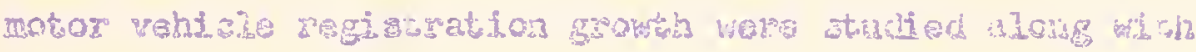

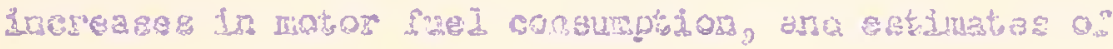

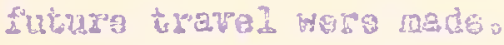

3o Tolerable and resign stondards yse ceveloned and used to me.

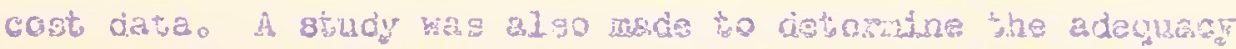
and cost of usintenence.

4. A खurvey of current thas

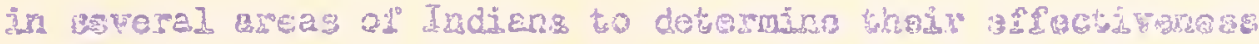

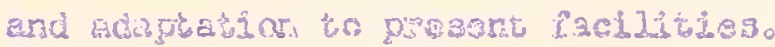

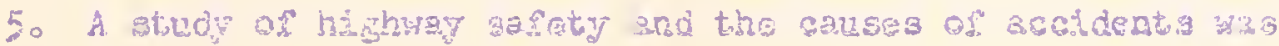

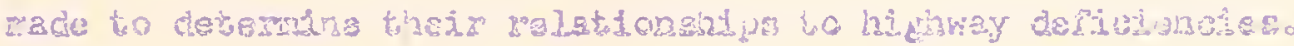

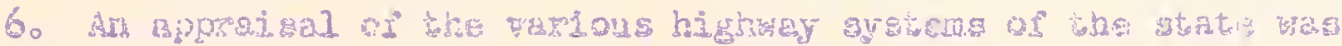

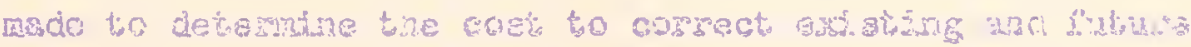

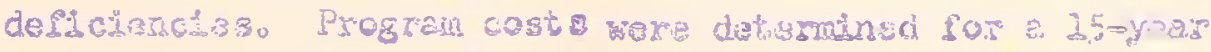

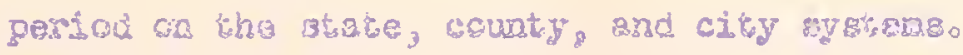




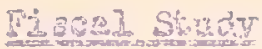

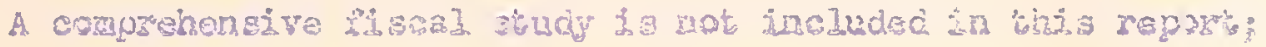

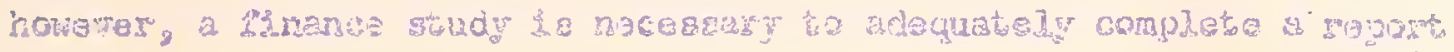

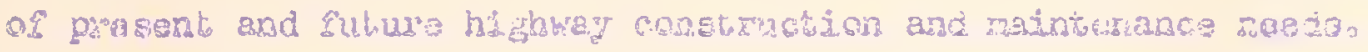

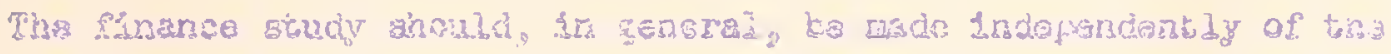

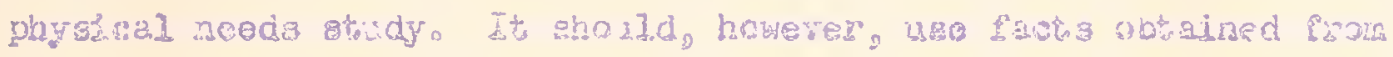

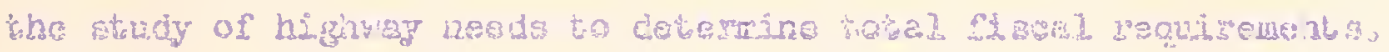




\section{Chepter I}

\section{ECONOHIC SFRUICES}

\section{Bosic Reasone for Hotor Vonlele Transporisilion}

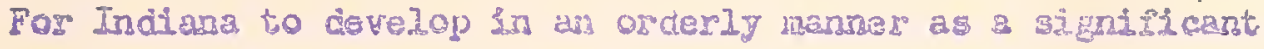

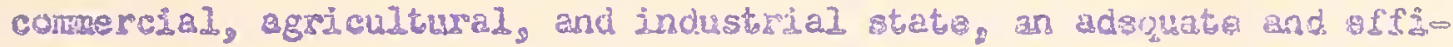

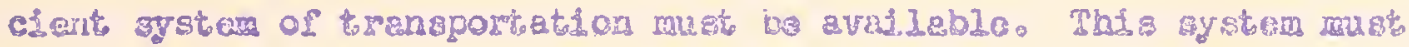

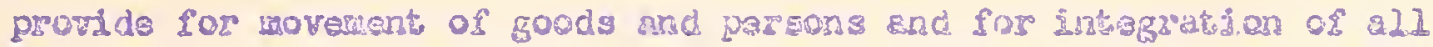
comanition with the oconowy. Tha role of transportaton has ban so

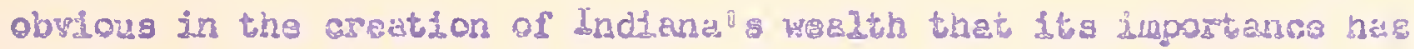
byen oferloolsed. For any communty to progress goyond a subsistance

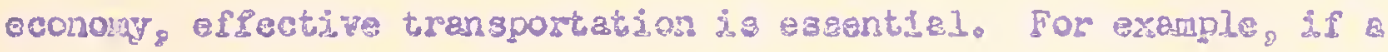

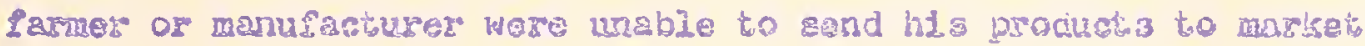
for congumption by others, there weuld be little raason for wroducing mors than could bo congured in the logal communtoyo dow-cest, Mass production technduges would not pe injortant if products and serraces

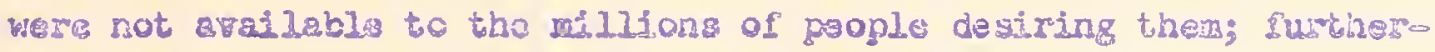

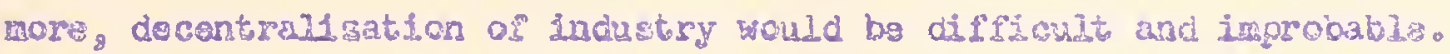
Trangportation makes poszible the Lntsrchenge of goodis and service opens markets to the Indtana producer $1 \mathrm{n}$ broad areas, makes products From distant locations evajiable to the Inciana censureag and has a significant oflect on erapleymast.

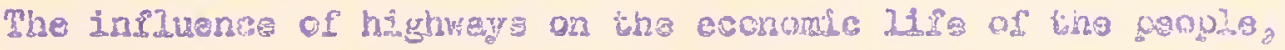
and the deponcence of fermes, businesmen, and Latorng in every cornet of the gtate upon the motor vehicle in their dojly activitis is certainly an ingortan iector. Furthermors, the econonte life of our netion is rapd.dy beconing degendent on tha motor ronirdeo

Indiana has always sequiged trangpotation for comerase, agriso culture, and industry and for the daily deaige of paple to carunicato. 

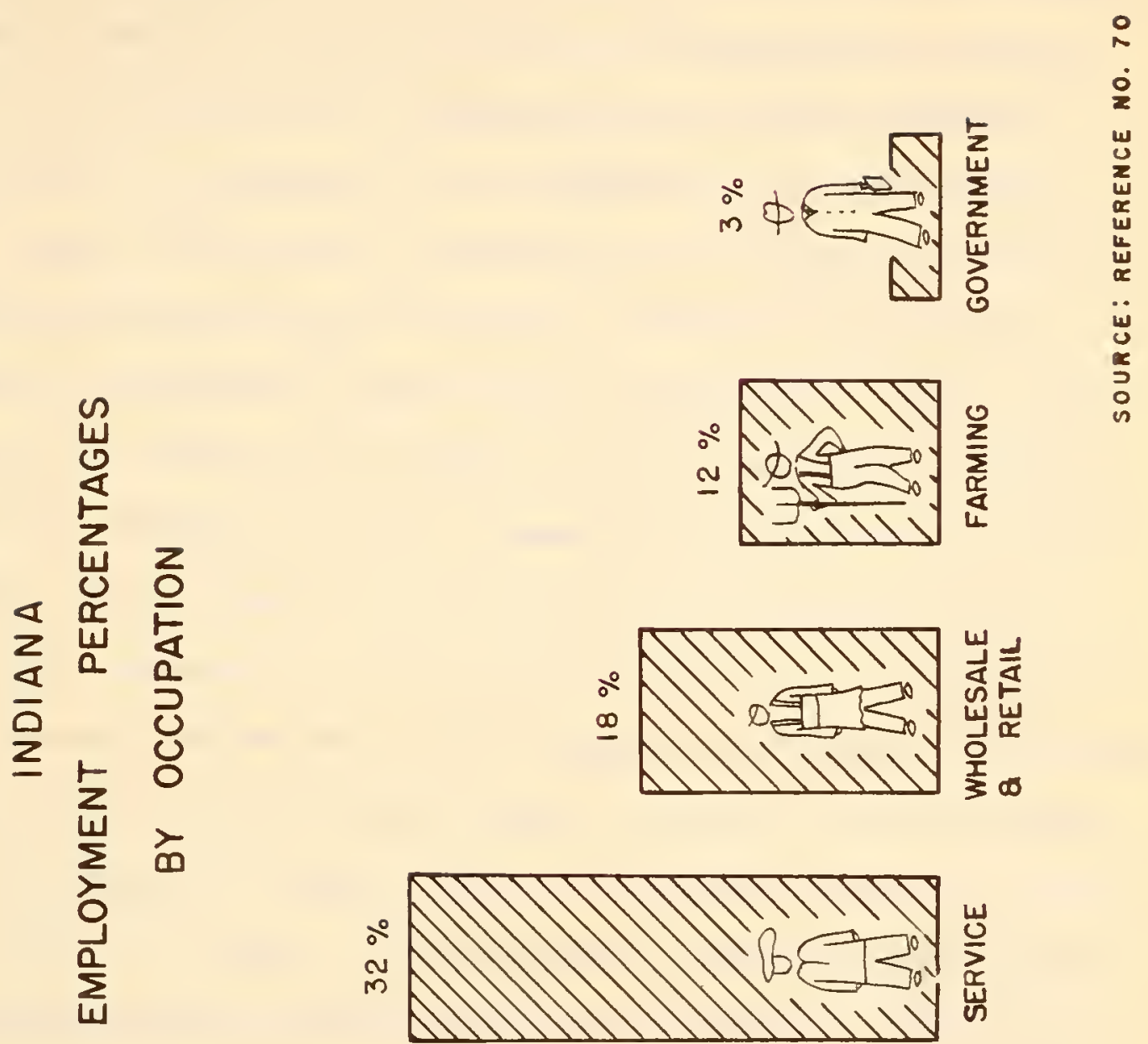

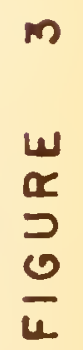
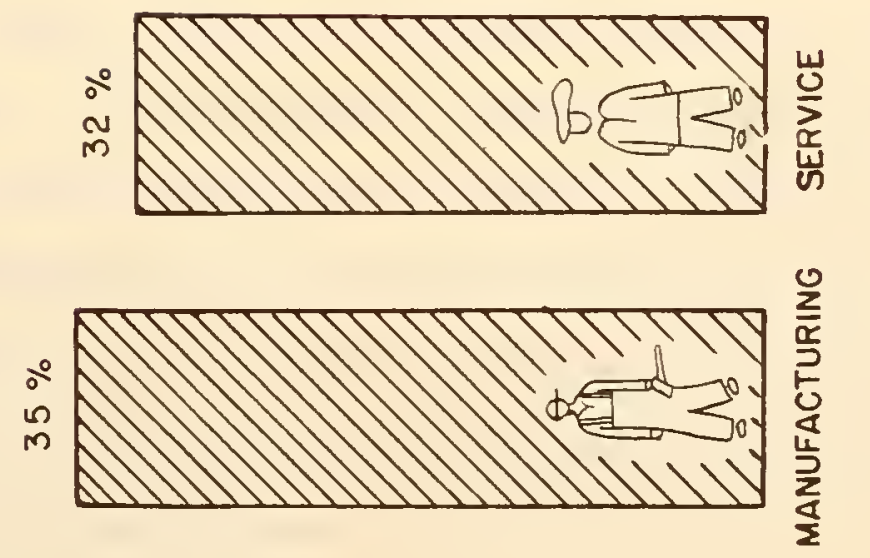
In the early years of the nation and Indiana, transportation was primarily over routes that were nothing more than Indisn trails. In the early $1800^{\circ}$ s the construction of the National Road (U. So 40 today) and canals across the atate edded to the transgortition system. Later the raflroad repleced the use of the roads and cancis except for local transportation. Highways were not of mojor inportance again unt1l the development of the autamobile in the early 1900 's。 Since 1900 the role of highways in our economy has grown con= sistently becauss the highly flexible, convoulent, and adsptable service wes furnished by motor vehicle transportation. Most of the early motor vohicles were pasanger cars which were soon to repliace the horso and buger in everyday commuication among people: As notor vehicles grew in mumber and importance, use broadened and special types wore devalopad to sezve specific purposes. New fields of service such as motor bus and motor truck transportation developed. Since 1920 the growth of the motor truck hes been very raptdo the early trucks wore of single-unit degign, usually on harderubber tires, and the payload carried was ama11. In recent years the number of heavy trailer combinations and the wolght per unit have lncreased at a rapid rate。 Furthermore, the tonswiles of cargo carried by them has increased. Today, highway transportation is a great industry carrying nearly one= Iifth of the ton-ailes of Intercity freight and about nine-tenthe of the intercity passenger transportation (5)

A rocent survay mado in Indianapolis indicated that approxinately 70 percent of the freight moved in and out of that city by highwey transportation (55)。 Furthermore, it io estimated that approximately 90 percent of 211 intercity passenger transportation to and fram

* Nubars in parentheeos rofer to biblography. 


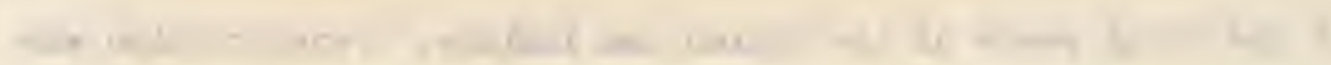

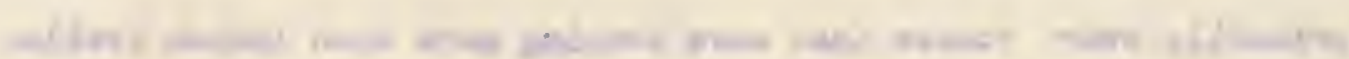

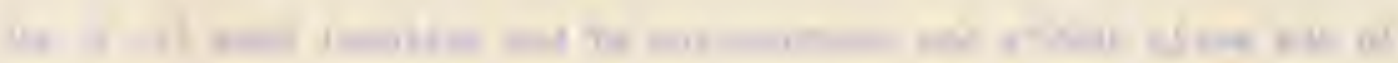

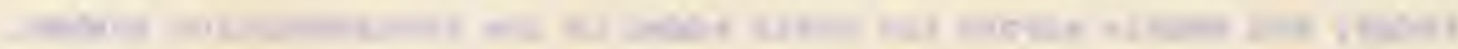

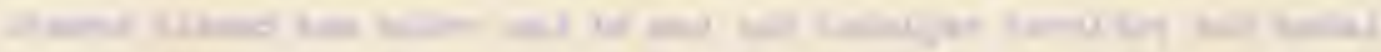

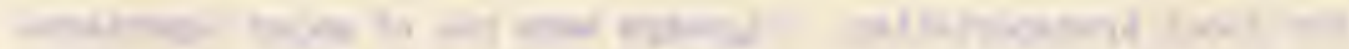

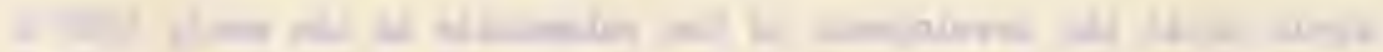
an

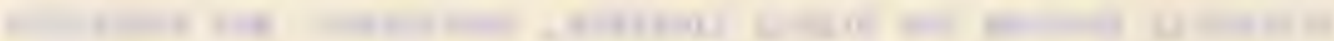

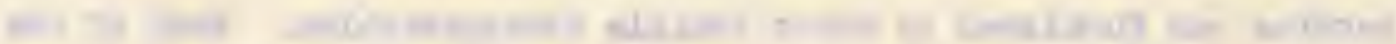

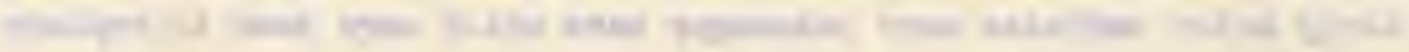

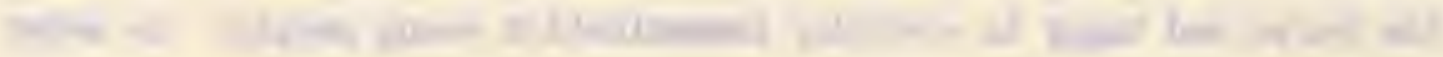

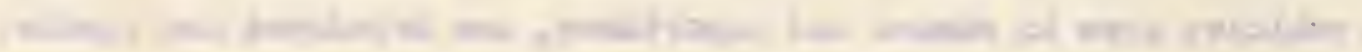

art

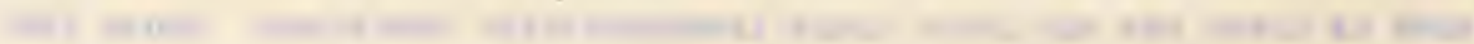

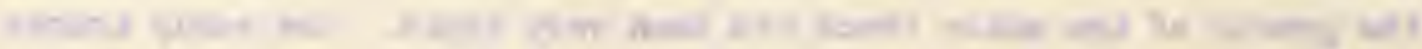

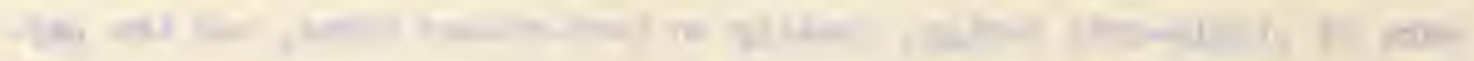

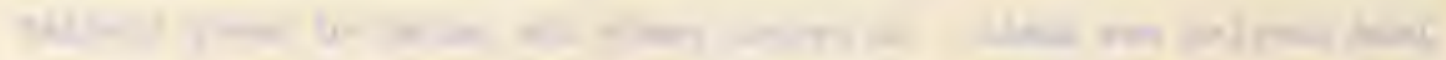

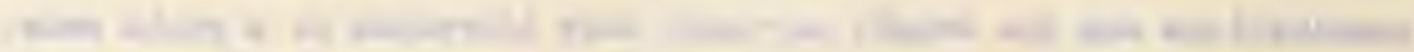

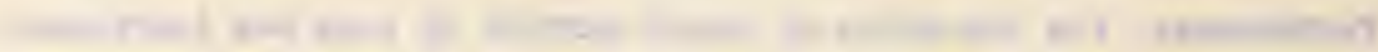

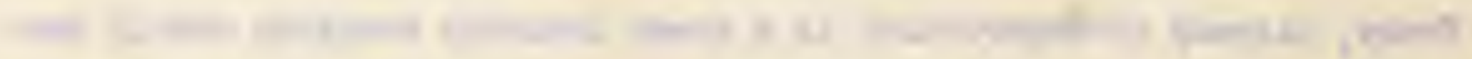

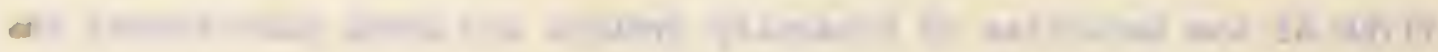

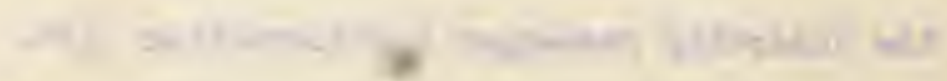

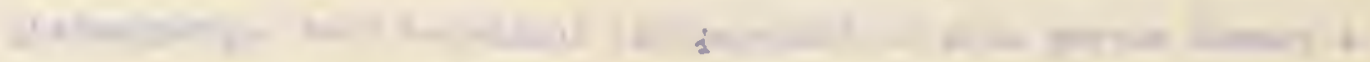

can-

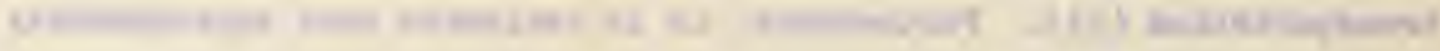

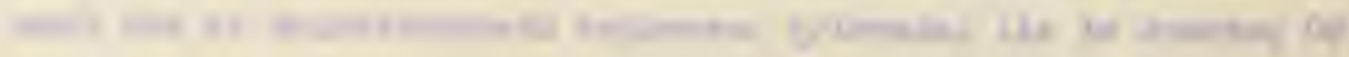

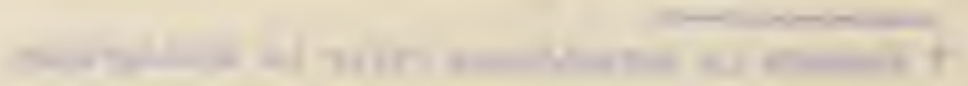



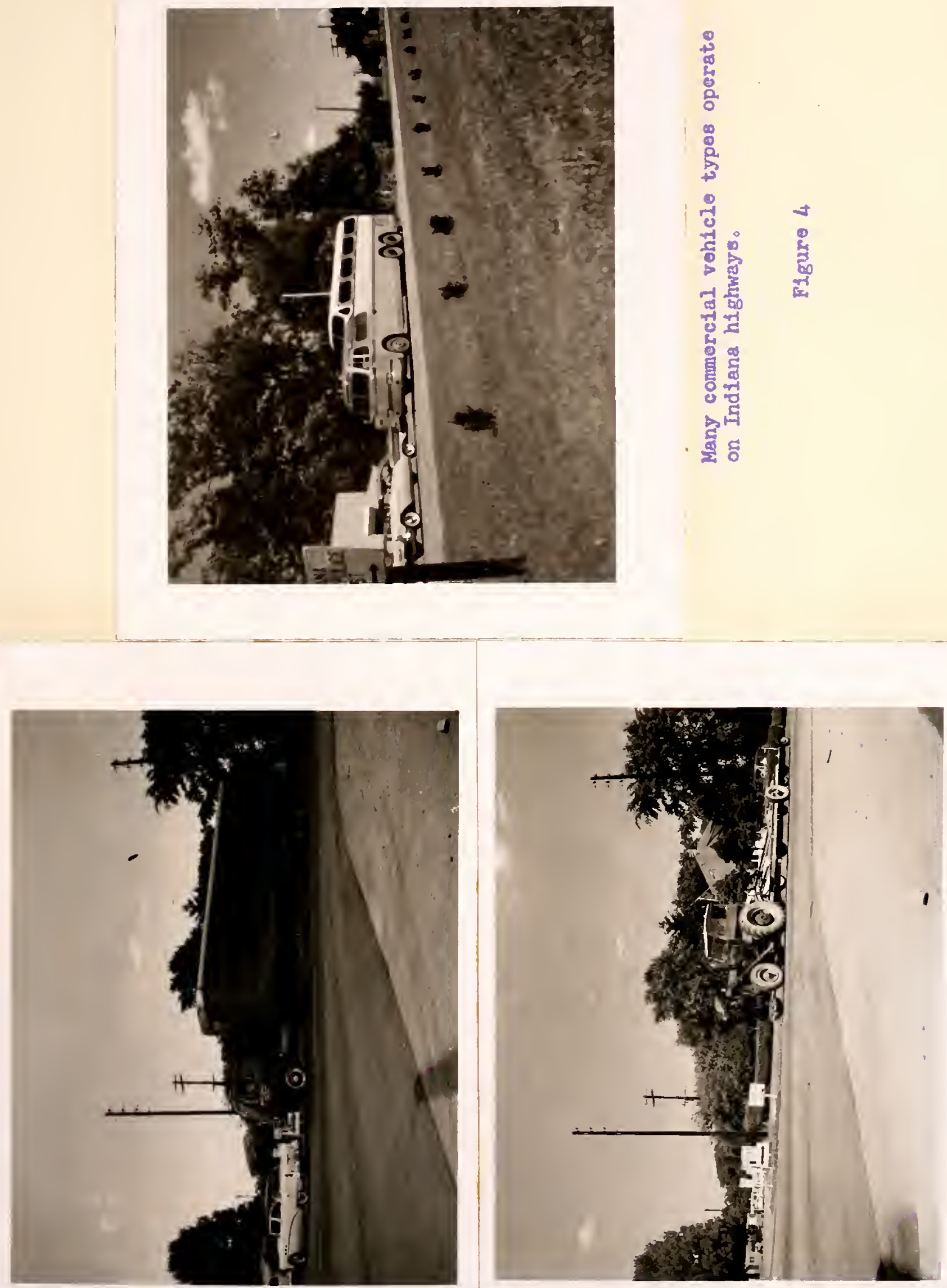
Indlanepolis was by private auto and bus, with 85 percent of the total by private auto.

\section{Econamic Impact of Hotor Vehicle Use}

Highways produce great benefits to agriculture, industry, education, and national defense. It is very difficult, however, to measure the exact Influence of highway trangportation on the state and national economy. Many observations show the striking changes which the transporting of persons and goods has produced on our everyo day IIving habits. The acconpanying map of Indians illustrates some of the products and comodities produced in different areas of the state. As can be readily noted, Indiana produces many varied and valuable products of agriculture and industry, and all are availablo to every citizen of the state because of effective highway transport-o ation。

Indiana is knowa 28 "The Crosarosds of Amertca," and the motto is very appropriate. The state's strategic lacation on natiunal north-south and eagtewest routes requires that its highways bo adequate for Indians 8 bonefit and for the benefit of the entire midewest and nation. The Great Lakes on the north, the mountainous regions on the south, the large centers of population on the east, and the vast agricultural areas of the west cause much of the cross-country craffic to be channeled through Indtana. During the summer of 1956 , a suryey Indicated that orer 40 percent of the passenger cars on the state's primary rural highways were non-Indiana vehicles (5I)。

Importance of highways to Hoogiers is also shown by the fact that in 1955 there were approxdmately 1.5 million passenger cars and 300,000 


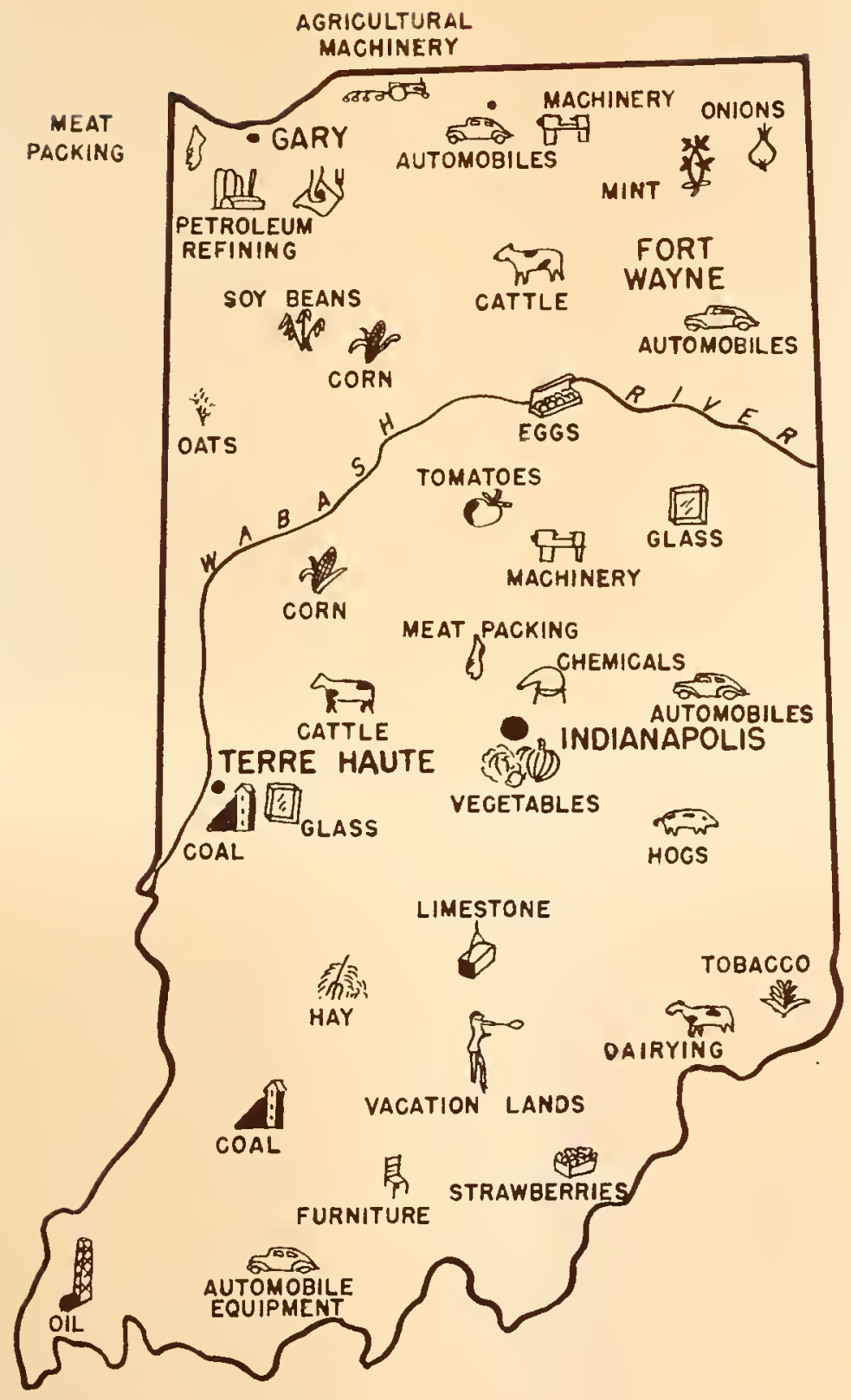

LOCATION OF LEADING PRODUCTS \& INDUSTRIES IN INDIANA

FIGURE 5 

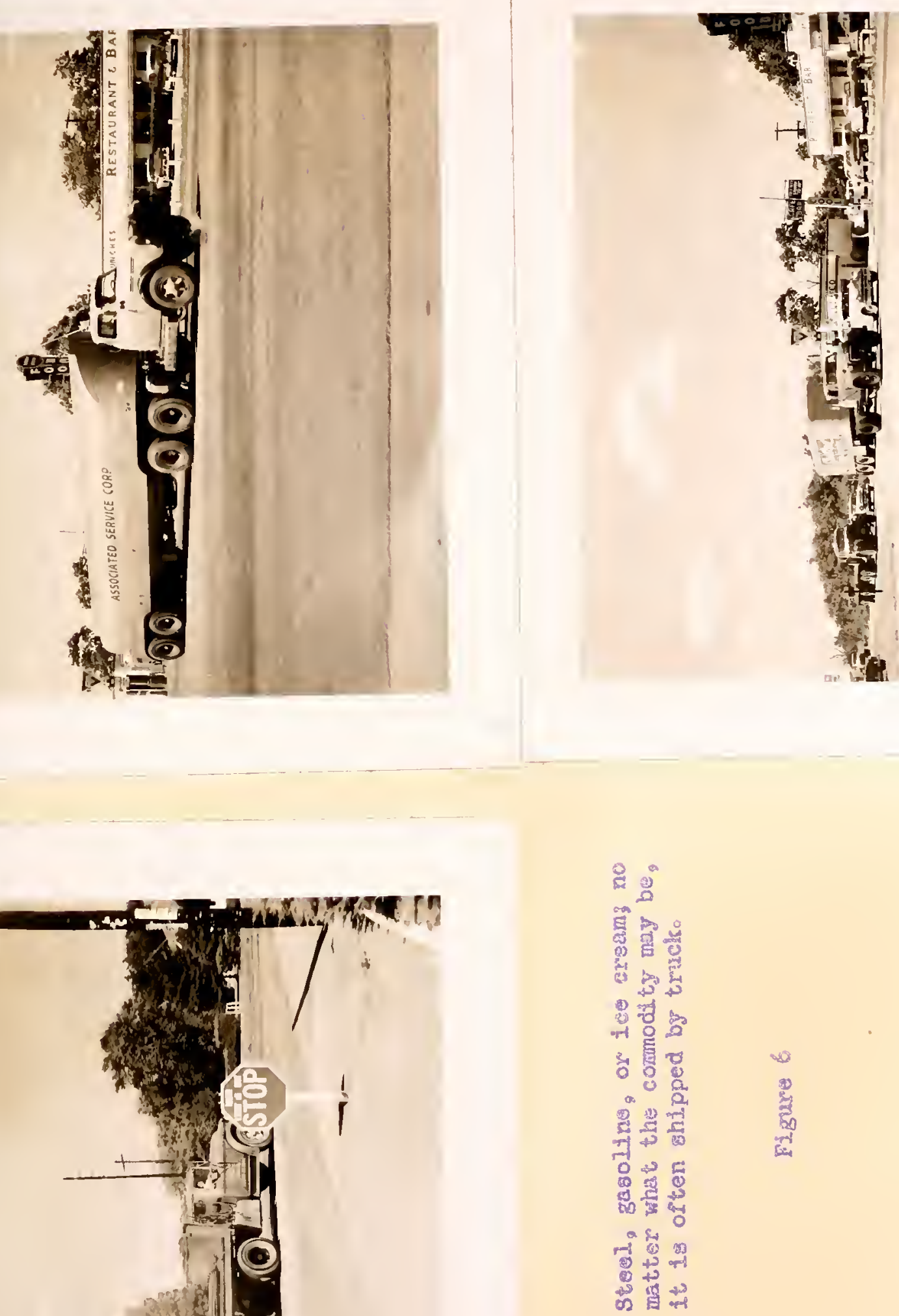


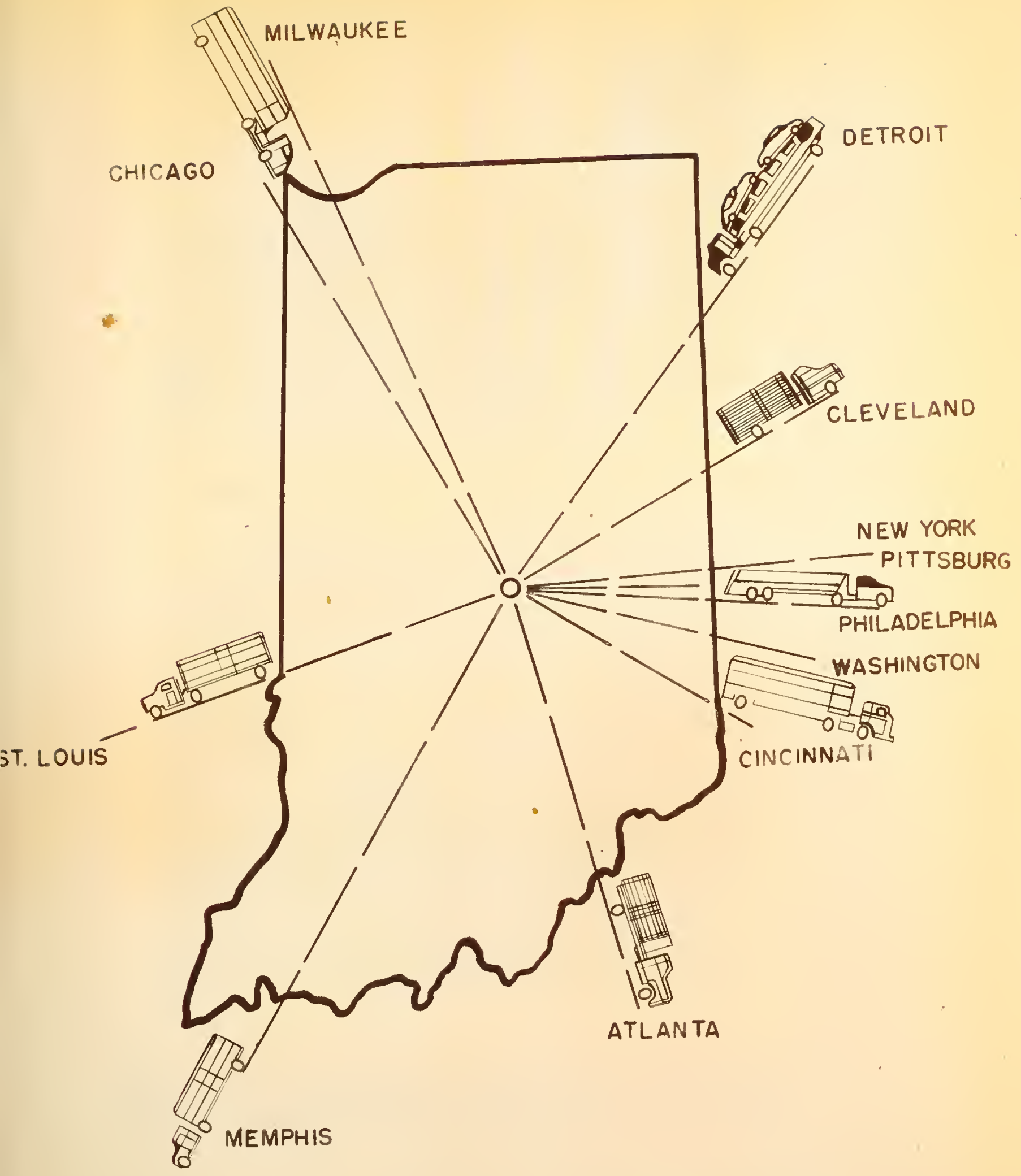

INDIANA IS KNOWN AS THE CROSSROADS OF A MERICA 

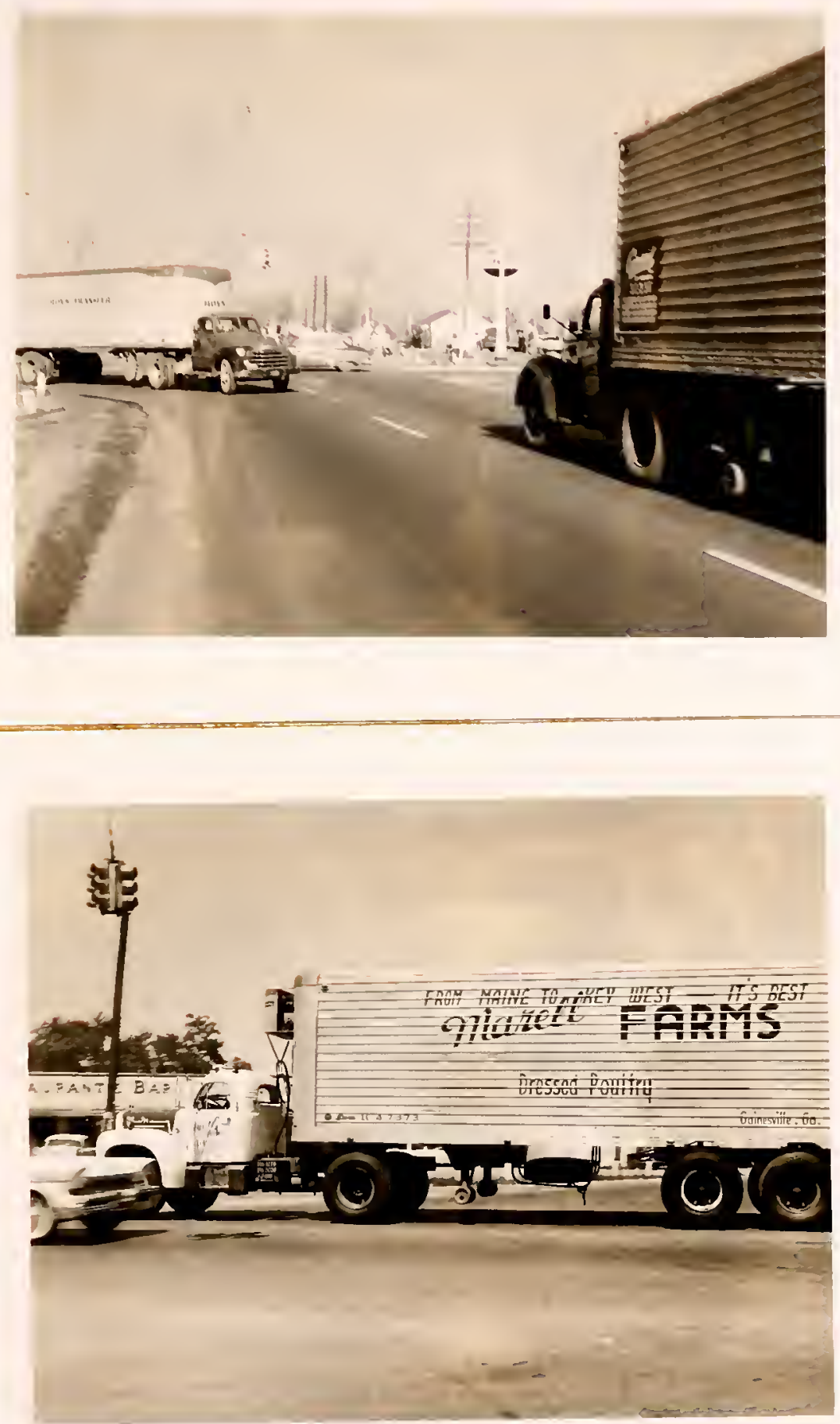

There ars mox than frice as many trucks in use In Indena tode. as there were in 1940 . Truck-todler cominations

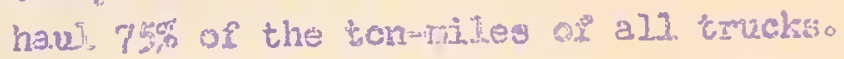


trucks registered in Indiana (70). Excluding drivers of farm trucks, ther were about 325,000 people omployed in highway trensportation Ladustrles (55). Furthermore, the trucking induetry was responsiblo for about one out of every gix paychocks. In about oneobalf of the gtate's towns and village日, highways provide tho only moans of frelght transportation used. It wes also found that all of the 899 postoffices In Indiana use highway transportation and over 500 or them are serviced only by highways $(55)$ 。

\section{Agriculture}

Indiana $1 \mathrm{~s}$ an important agricultural state. About 85 garcent of the land area jo used for farming and over 20 percent of the popruation of Indiana lives on farmo Since more than one-fourth of all tricks giotared in tho state are farm-trucks, it can be readily seen thet farmo ers rely heavi.ly upon highway transportation for the movement of supplies and products $\operatorname{lram} \operatorname{farm}$ to markot (2l).

Indlans is among the four leading corn producing states of the country, and has a yleld per acre about 40 percent higher than the national average, Although this crop grows all over the state, it growg beat In the central region. Whe日t is the sacond wost Important crop in terms of acreage with hay and oats ranking nexto rhese crops ne usert ma1nly fur feed and a laxge portion of them are ahlpjed over the highways to market in many of the larges cities of the state and the nationo

Frutts and regetables are also extenaj voly grom. About cnes tenth of the tomatoes grown in tne United States comes from the fields - of Indiana. Large crops of potatoss are grown in the drained lowiands 
of northern Indiana. The rich muct soil of that resion often ureduces

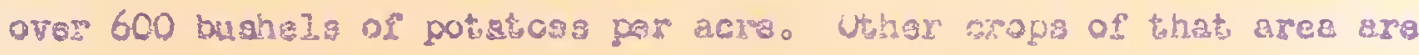
ontons, peas, cabbage, and colery, In 1955, trivks hawied about 94 percent of all fresh fruits and vegenables thst moved out of Ladiano 655 . Liveatock Darketine proquced woll over onzothird of the total fans income in the state during 1955 with hogs renking first la produce tion and cattie gecond. Every yar thousands of calres are saip pad from wostern and southern statos to ba fettened on Indiana farss a a difficult feat to accomplish without truck transportationo

In 1955 almost 100 percent of 311 1irestock shipped to the four major markete of Evansvile, Fort liayn, Indtanapolis, and Huncto was by truck (55). Thero 19 also an ever increasing domand for trucks to ship Ifvertock to warket outaide of Indzana and to ahip dassy products within and out of the state.

\section{Industry}

For more than 30 years manfacturing in the Undted States has baen decentrolizing。 Although each factory 18 normally not self eufficient, ths requirements of indiotry bew been accomplished by ners

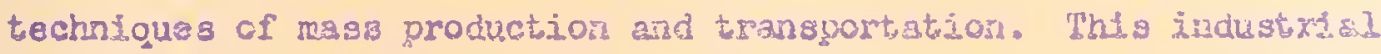
reliance upon many separate organzations for supply can ba reacily 11lustrated by the manufacturo of automobides. A gingle mutoliotive company ray depond upon many planto to appply st whth partes and atater. 1813. lo koep its supply lines sunning continuoubly with maxtaum ocon orny, highway transportation is an absolute necesaity。

Although Indiane fo prinarily know as an agriculturaz state 2 its Industries have astional prominames. Probsbly tho most impartant in tho atate today is the production of steal, in which Indians ranks fourth 
EVANSVILLE
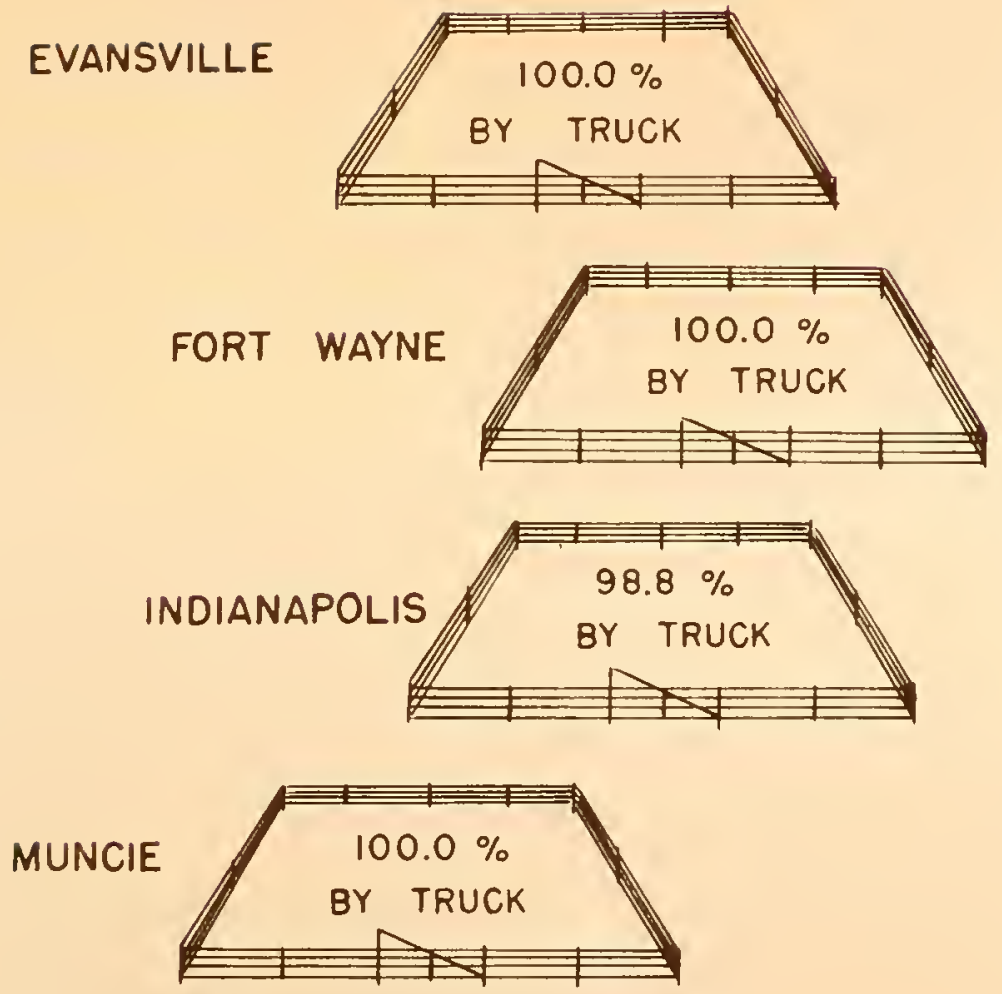

IN 1955 ALMOST 100 PERCENT OF ALL

LIVESTOCK SHIPPED TO INDIANA'S FOUR MAJOR LIVESTOCK MARKETS MOVED BY TRUCK

FIGURE 9 
If the nation. This Industry is centered in the Colurat region, with the world'b largest steal plant, in the Gary aree (21). In asaspy Whiting is located one of the world's largest ail refineries whore crude ojd is transforned into various refsrod petroloun products which are often shipped oy truck to yarious ereas of the raidswesti (21)。 Although not widely publicized, Indiene ranks gecond arang all states in automotive products manufacturing (21). Factorios in such cLties ae Indianzpolis, South Bend, Andorson, Murio, and Evangvile produce eutomotive parts and toole and ajxplane engines and partiso Surveys made at factories in each of those citios indicated that oraz 90 porcent of the goods ontoring and leaving were carriod by highway transportation (55). Nany of the state ${ }^{9}$ other industries auch 8 s the manufacture of machinery, furntture, pharmacoubicals, and pottery are also dependent upon hithway transportation for theis exigtence. Education Safety Dofense, and Recreation

The bangits derived from highway tiansportation are so vast and ramed that they ase beyond objective meaguro. In addition to the use made of the highway system in Indiane" induatial and agricult ral and agrecultural sconomy, g great smount of travol is for educst1on。

Because of the school bus, there se no longer a need for tho older Sasiloned, ono-5oom school house. Todsy, cany of there schoole of the

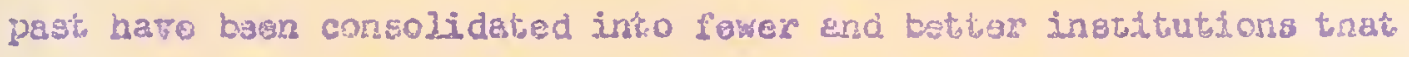
aro capable of Giving children tho proper aducation needed to prapare them for the warld of tomorrow. The extent of the Hoosler's rellance upon highway transportation for oducation 1 s illustrated by the fact that in 3953 there were 6,248 gchool buses regiatered in Inddane (38)。 


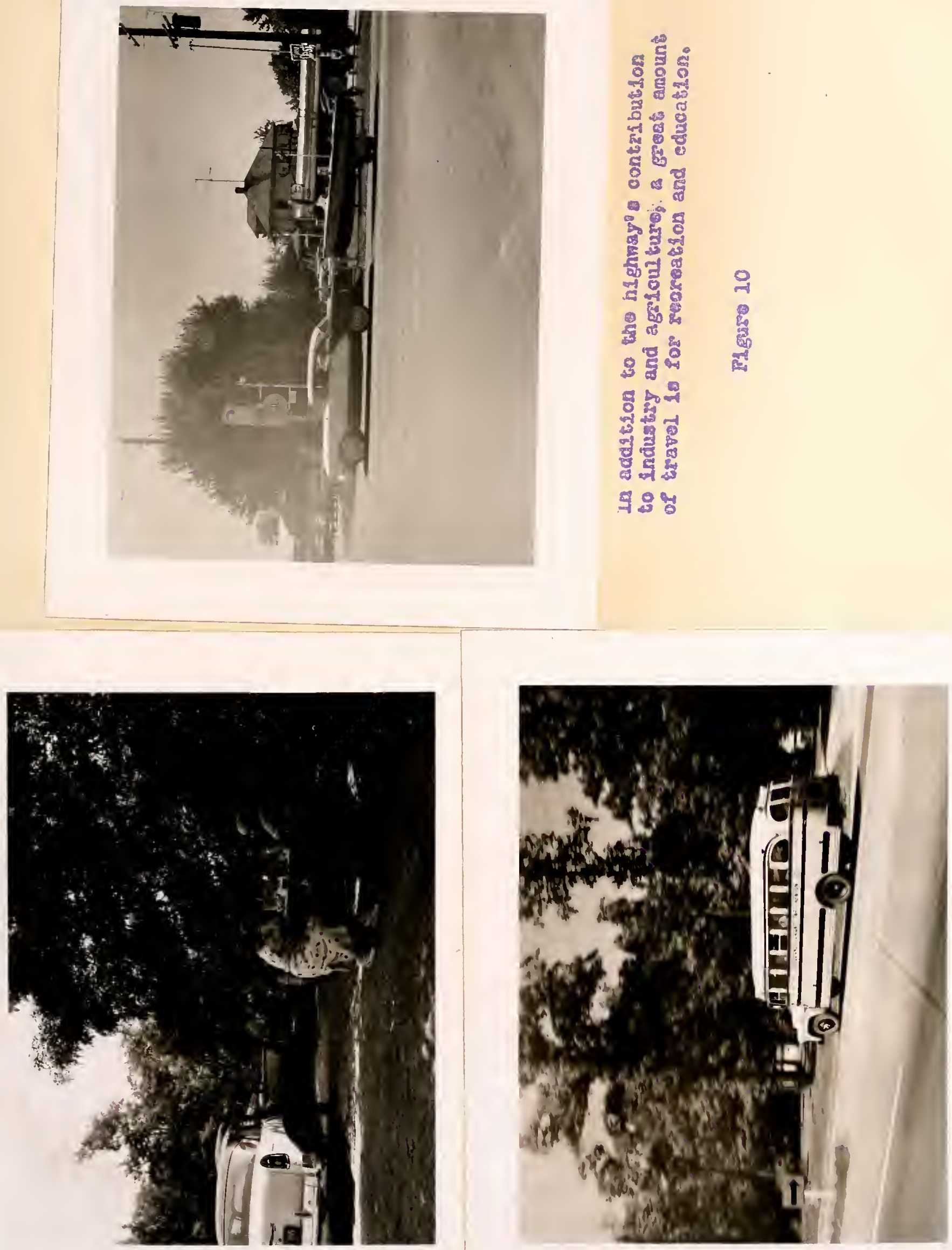

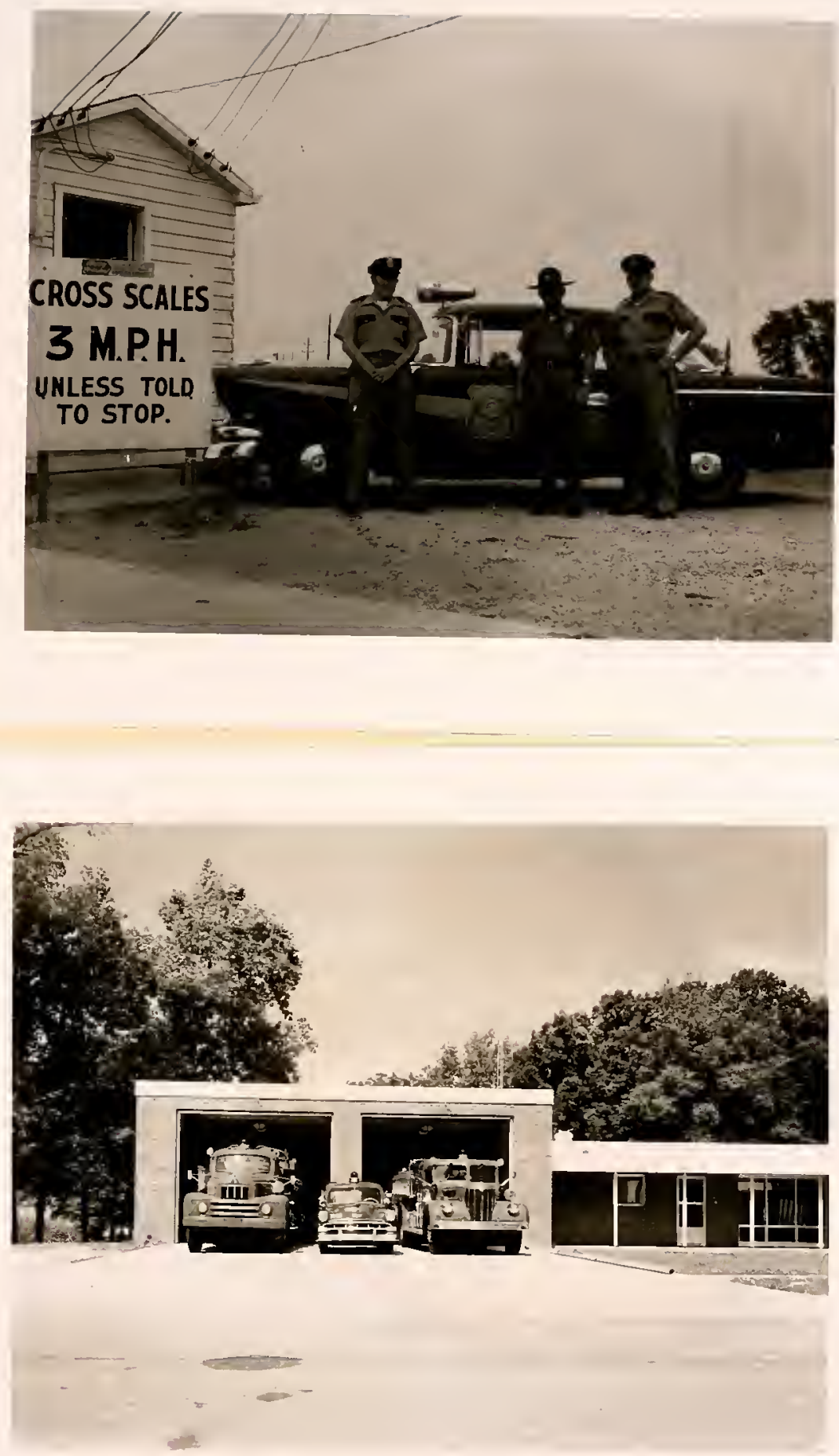

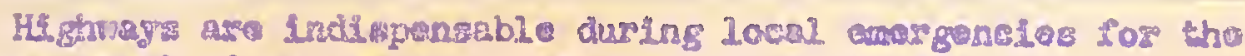

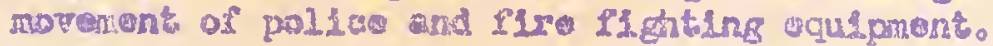



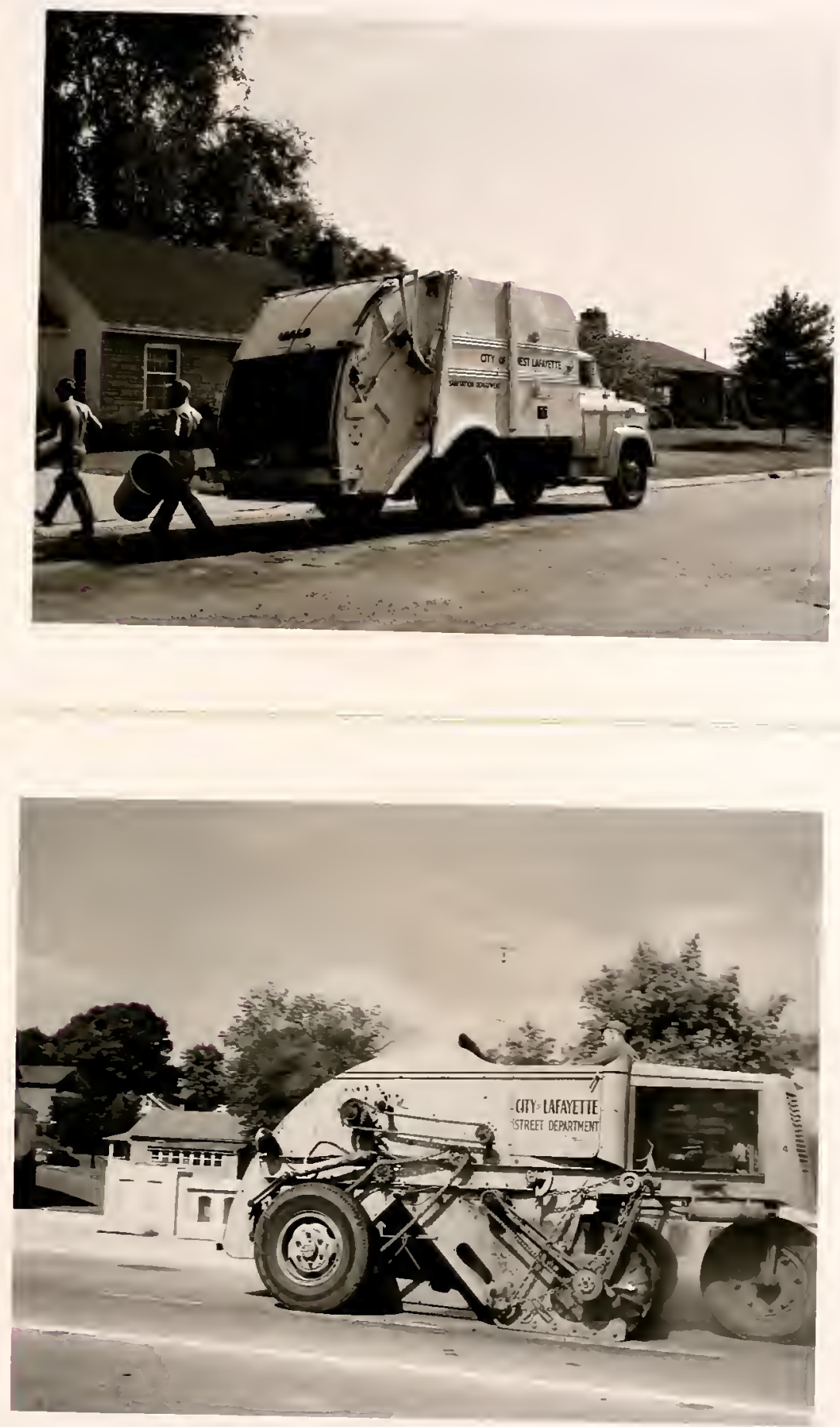

High standards of sanitation nould be almost impossible to maintain without streot and highmay networks。 
On a nationgl basis it bas been estinated that spprorluately 25 pero cent of the public school studento are carried by this fort of transportation $(3 \&)$.

During local emergoncies the highwaja are of paramount, importanco. Their function in oxpoditing the moveront of polise, fire-fighting equipo ment, and other communty servlces do invaluable. When apeating of onergencies, one must conkider then on a netional as we13. Es local lavel. National defenso cannot os maintalned without sdequkte highway facillties. The federal and stato govarnments have reulized this

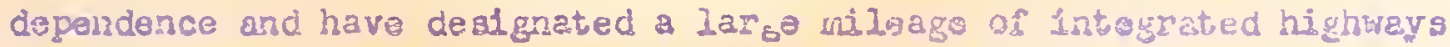
to be uged for defonso in case of areuny attacke

Tho carventence of highway trangportation for recreat,icnal gurposes cannot te sverlooked。 spproximately 70 percent of the tmigs excesding 100 miles in length mads in the United States in 1955 Ware by automotile (38). Hang of these vers for vacations and have cauesd our highweys to bs crowded with vacationing tourists, especieliy during the sumer mosthso in a nationwlde basis, it his toen found that neerly 85 parcent of ail sacetions by furiuss are by private car (38)。 Highay Prsmsportation ana Caties

Kany cities, towns, and villages in indiaza are completely dopendi. ont on busas and trucks for trensportation commucation with the rest of the State. within cities, particularly larger ones, deperdance on the motor vehicle for transportation is increastug。 Thls increase is drectly attributable to the advantases afforded by motor vehicles and the desire of poople to use then. It is no longer nocessary for people to live within welking distance of their jobs or the downtown shopung districts. Many do not live noar routes of mass transpurtation service. 
These conditions are responsible in turn for certain urban travel trends which have been evident for the past 20 years and which continue to gain momentum. Among these are the location of residential develop ments and industrial plants in the suburban areas, the establishment of shoppling centers in outlying locations, and the growing congestion of street trafic in the central buslness districts. Ihese trenas are makm ing it increasingly desirable to live in the suburbs where the environo ment is more conoucive to a healthful and relaxed way of 1 ife fooplo are no longer willing to sacrifice conforts and privacy for the convenience of being located near the congested business district or the place they work. The automobile and the modern highway make these destinations accessible from distant locationso

If Indiana"s econom is t keep pace with the desires and energies of Its progressive population, highwey transportation, properly integrated wth other modes of transportation, is necessary. Highway, however, can only provide adequate transportation when they are in adequate quantity and conditîn. 

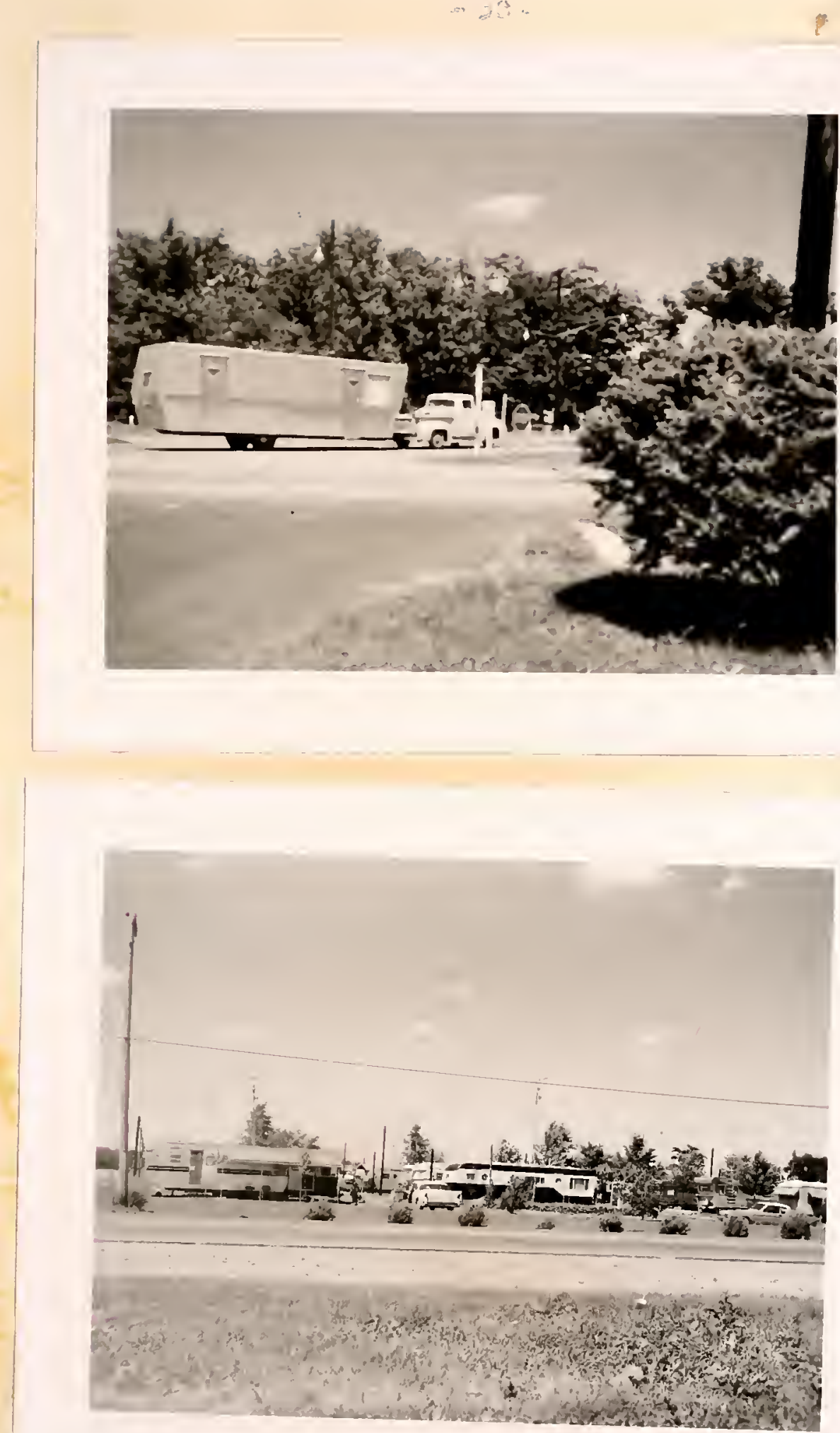

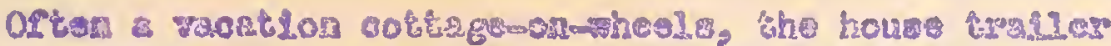

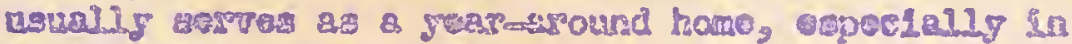
Postogroming oonerund tas. 

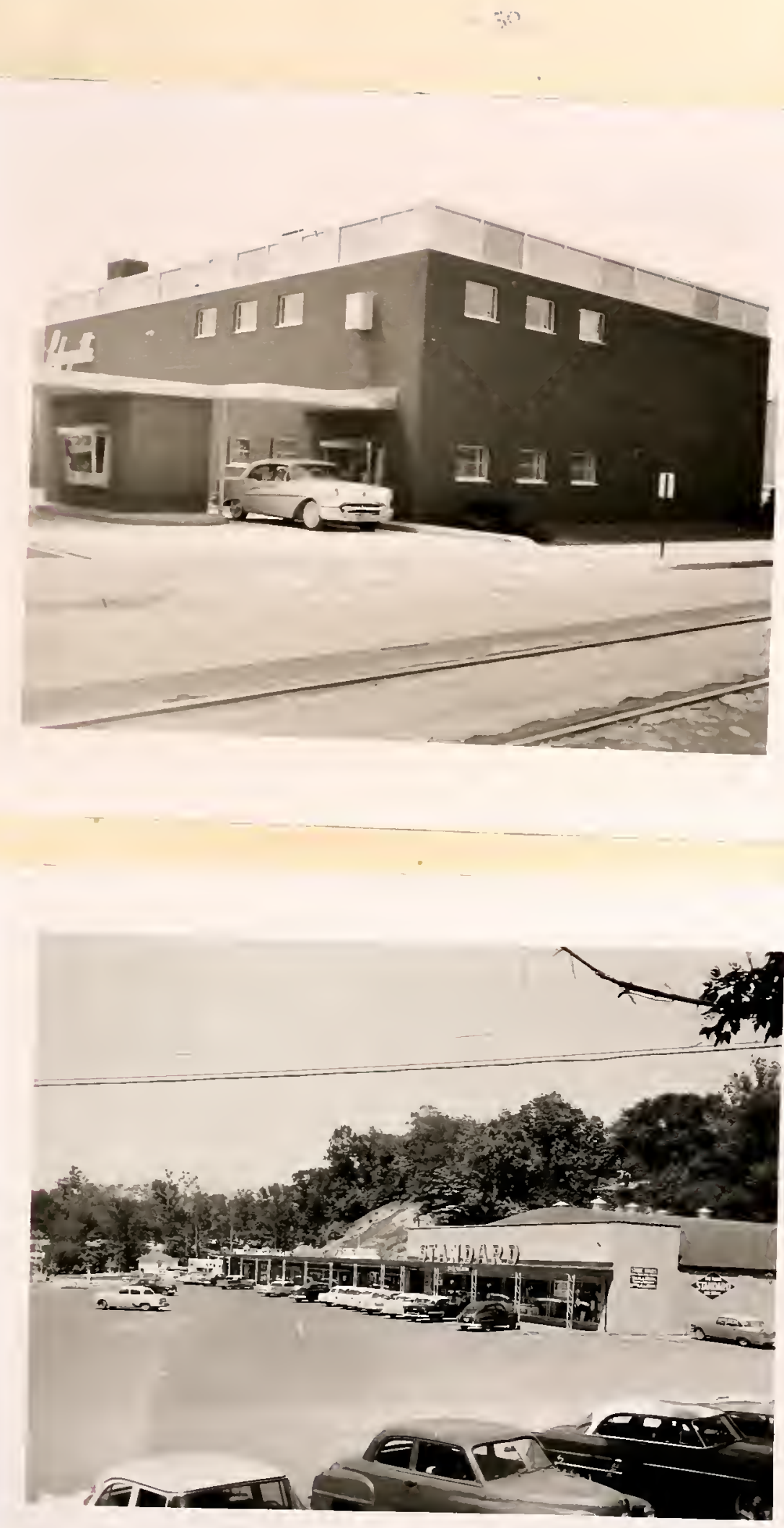

Dewntomn confagtion and lack of parking facllitios havo raio arivo-in artaropisos snd wuburban shopping cortors prezy dogirablo. 
.

- -
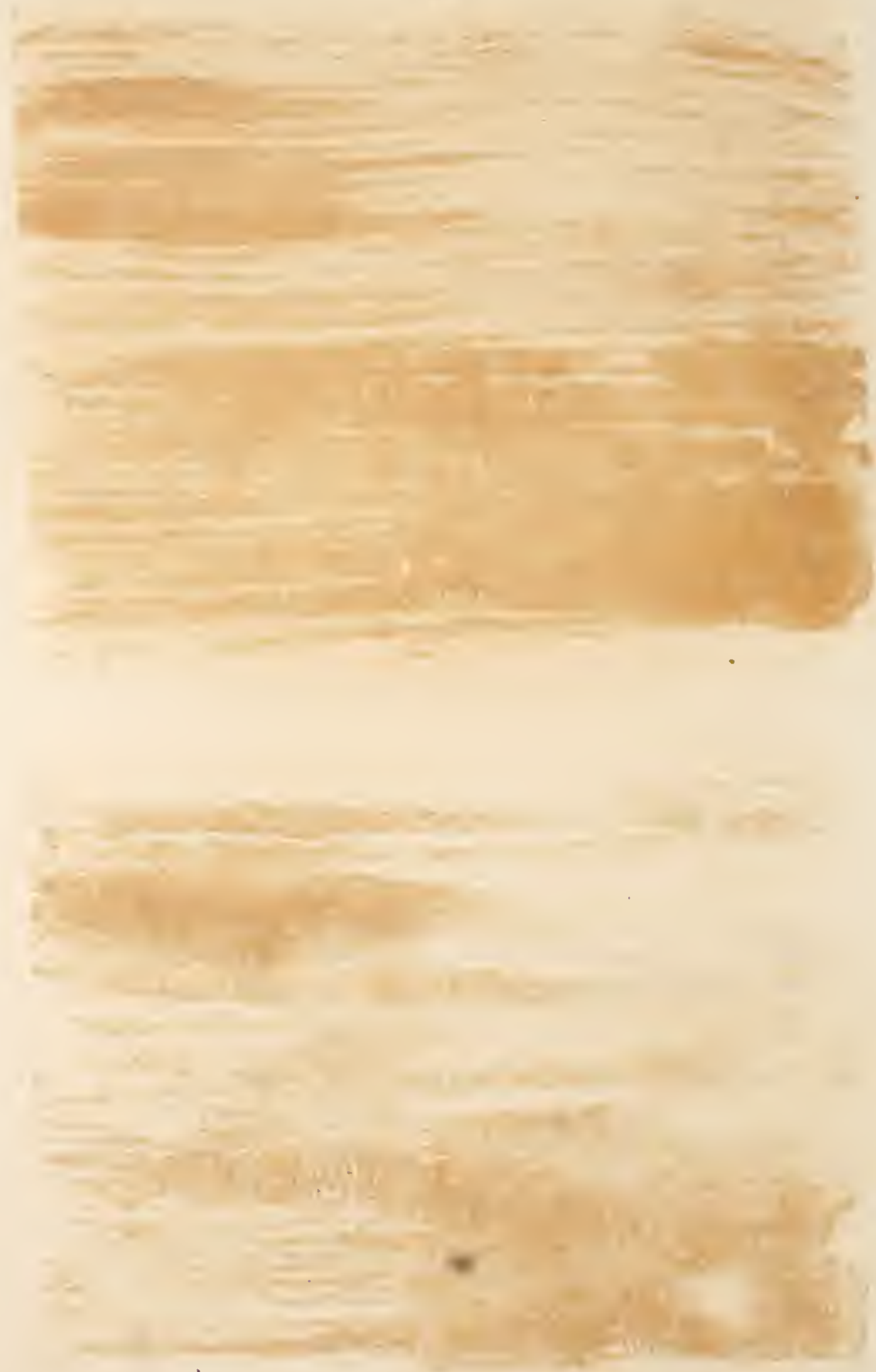

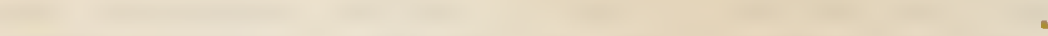




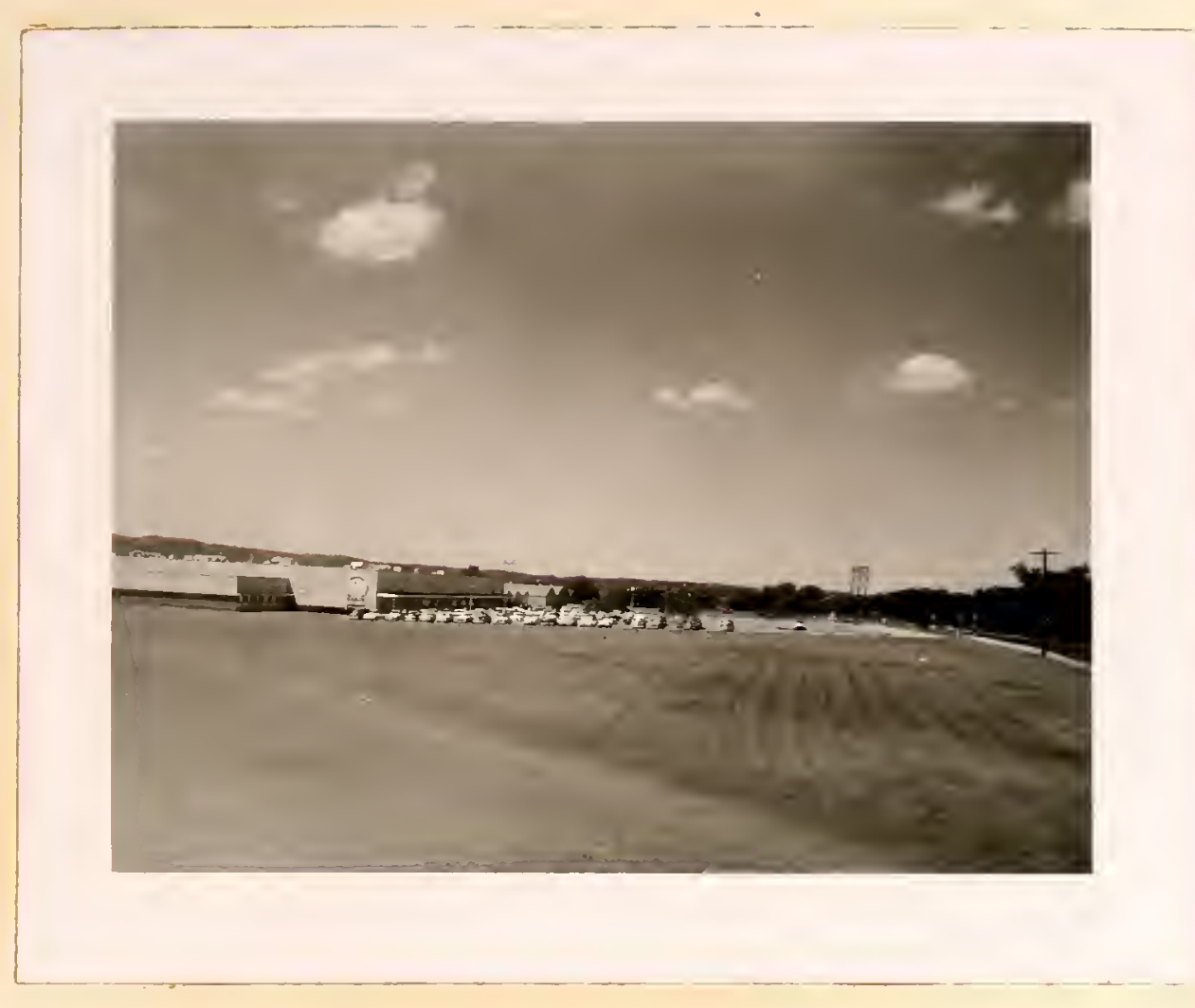

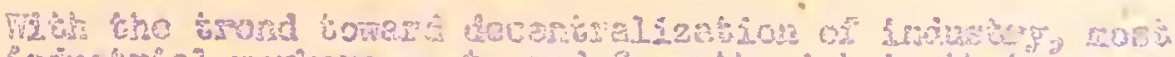

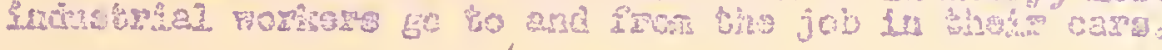

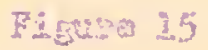


Chaptar II

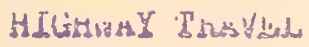

\section{History of Road Building}

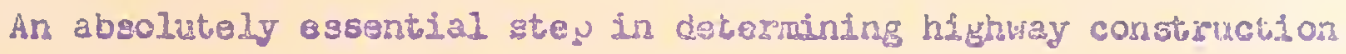
and maintenance needs and developing adequate long-range plans is the study and anzlysts of highray travel trends. present and last couditions mast be used, in nost casss, as a basis for tre prediction of future conditions. An analysis of the many factori whin affect the movernent of highway trafric was peroromed in this study such finctors as the development of the roed systam, cnaracteristicg of hignway travel, population growth, motor vehicle regititation, and motor vohicle fual consumpition, have a disect relationship to the complex higrswa groplem facing Indiana today:

Although roads wers developed slowly, they were recognd ued early

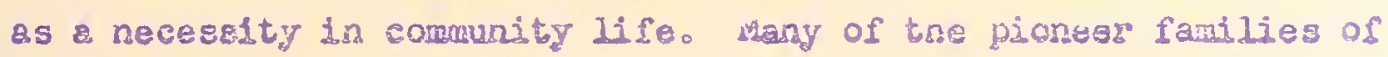
Indiana established horesteads in the triangular pocket of acuthitostag

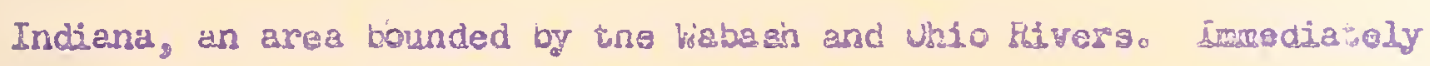
those ploneers began cutting crude roads from theis homesteads to tho river landings in order to move their on uplies to water tansportiotiono Flatboatg were walting to transport the sstiler ${ }^{\circ}$ produce on the whio and Missisalppi to ready marketg at Mew Urisans.

As eariy as 2805 Congress eracted legjalation suthordath the building of a hishway from Cumberland, idaryland, westuard to IIIinois (45). The route through Indzane was from Richnond via Indlanajols so therre Haute. Neanwhile Indiane was engaged in an alatibious program of "Internal Inprovements", estinated to cost, whei finlshed, more than ten milition dollarg (13)。 Conetruction was etirted on a state foed from Naisen to Indianapolis, and thance to Lake Hilichigan (13)。 
In addition to building rouds, the program of "Internal Improvements ${ }^{M}$ callec for the construction of a aysten of canals to provide chsap water traneportation for farm crops and for the products of mines and factorios of the stato. The Central Cansl, started in 1832, w8s Lntended to connect the Wabash-Exde Cens I with Indianspolis and Evanavillo. Feeder roads wero built to the barge landige along the canale, opening up tho farming regions and surthor increasing tho popalation and worlth of tho state. Loter when raliosda came, the slow moving canal boats could not compate favarably with this modo of overland trangcortations and most canals Here abandoned. Local roads becam more useful thar ever with the cautrg of the roilroadso Then, es now, a large part of 211 the freight carried by the railloads nad to be collected and distributed by vehicles using the highways. With the development of the automoble, good roads pecane rore Lnportant to tho transport-conscious pooule of Indiardo waothes and botter roado wore required than those that had bean adequate for borge drawn vehlcles. Township and county roads were graded and resurfaced wh th gravol or crushed store. Many nles of city atrots ware pavedo Motor traffic in Indians and the nation had reached such progartion by 1917 that the Inancial burden and responstbility of ballding and maintaining a cannected system of intercity unin highways was too much for locel townehipg and couniy governments to bear. It wes in 1916 that the Congress of the Unftsd Stateg, rocogniziug national respon sibility for roads, enacted the first Federal Ald Highway ict, which allocated funds to each gtate contingent on thoir admintstrution by a recognized stato H1 ghwsy Department (13)。 


\section{Developrent of Rosd Builds ne Gencios}

Indians quickiy responded to the deminas of the people for botter highways. Action by the General Assemolies of 1917 ad 1929 roaulted in the creation of a State Highwgy Comulasono The highyay Commisolon, In Its formulative period of 1919 and 1920, was gran the task, wits the conoperation of the Federal Governant, to provide in the shortest period of time a system of highways that would sonnect county geat a and othar cities of 5000 people or more (13) o Stats funds and foderal

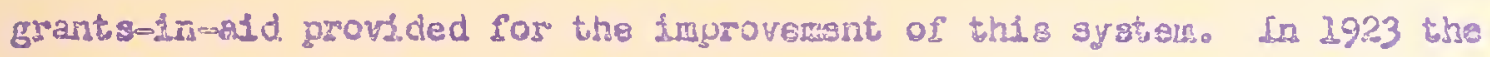
motor ruel tax was enacted o the Injtiation of the trend in Indiara that the highsays should bo suppostgd by the usars (23)。

Since its inception the Highwey Comnoghon hae bullt thousande of miles of roadways. The exdsting State Mural Sybtorn is conprised of 10,600 miles of bltuminous anc ports land cemont concrete prusmento and 65 widos of gravel or crushed stone surfacss.

There axe now epgroximately 76,000 miles of local rural roads which are the responstility of the counties $(52)$ o vrer 15,500 miles have dustless surfaces; 50,500 inles of this system have grarel or atono gurface; and 10,000 miles have unimgroved surfaces (52)。 dn 1955

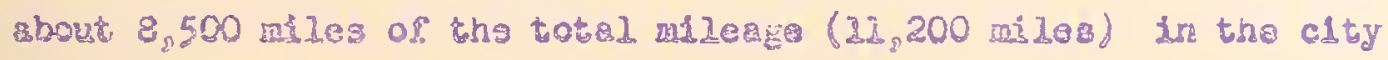

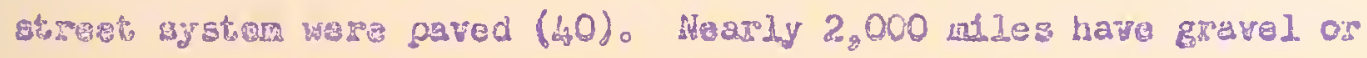

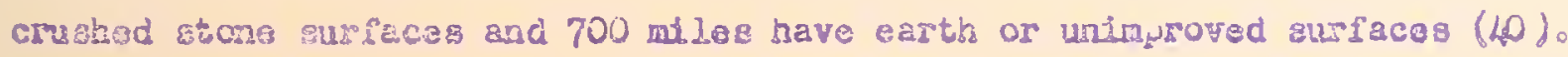

\section{Characterist103 of Highway Trave}

The trafPlc on Indiang'a rozdwgro includes meny tyuss of vohicles. At any given timo thoso sehicles aro making tripo to particular destina tions fron various origins for specific purposes. The routes of those 
trips often utilize roads of several different clasgfications and typeso The resulting distribution of travel produces traffic gtrears which vary in volume and conposition at different times and on different seco tions of highteys and sysiems of highways. All these characterlotics, together with the rato of traffic inzrease, are factors in deterrining present and future inadequacles.

The reasons why people make trips indicate why they own motor cars and what they expect of their highways. They are indices of the services which the highways should be designed to deliver. The results of studies by varjous highway agencles show that almost threos fourthar all automobile tripg are for essential purposes. About one-fourth of the total number of tivips are for sccial, recreational, and riscellaneous purposes (7I).

Motor vehicle trips are usually short. It has been determined by the U. S. Bureau of Public Roads that on a national basis, the average length of all vohicle trips is about sight niles. wole tian half the trips are under five miles and only about one percent are over 100 miles long (20). Timo is an important factor in determining people \& travel habits. Concertration of travel depends on the season, the Iionth, the day of the week, and the nour of the day.

Because of weather, vacations, and recreational activities, volume is highest in Indiana during the warmer months, April to October. Angust is the month of peak seasonal traffic volune while January is the low volume munth.

On the basis of days of the week, Saturday is the highest traffic day on all three types of highways considered - state roads, county roads, and city streets。 Travel cn Sunday is close behind on both stato and county roads but is far below the wsekday average on city strects 


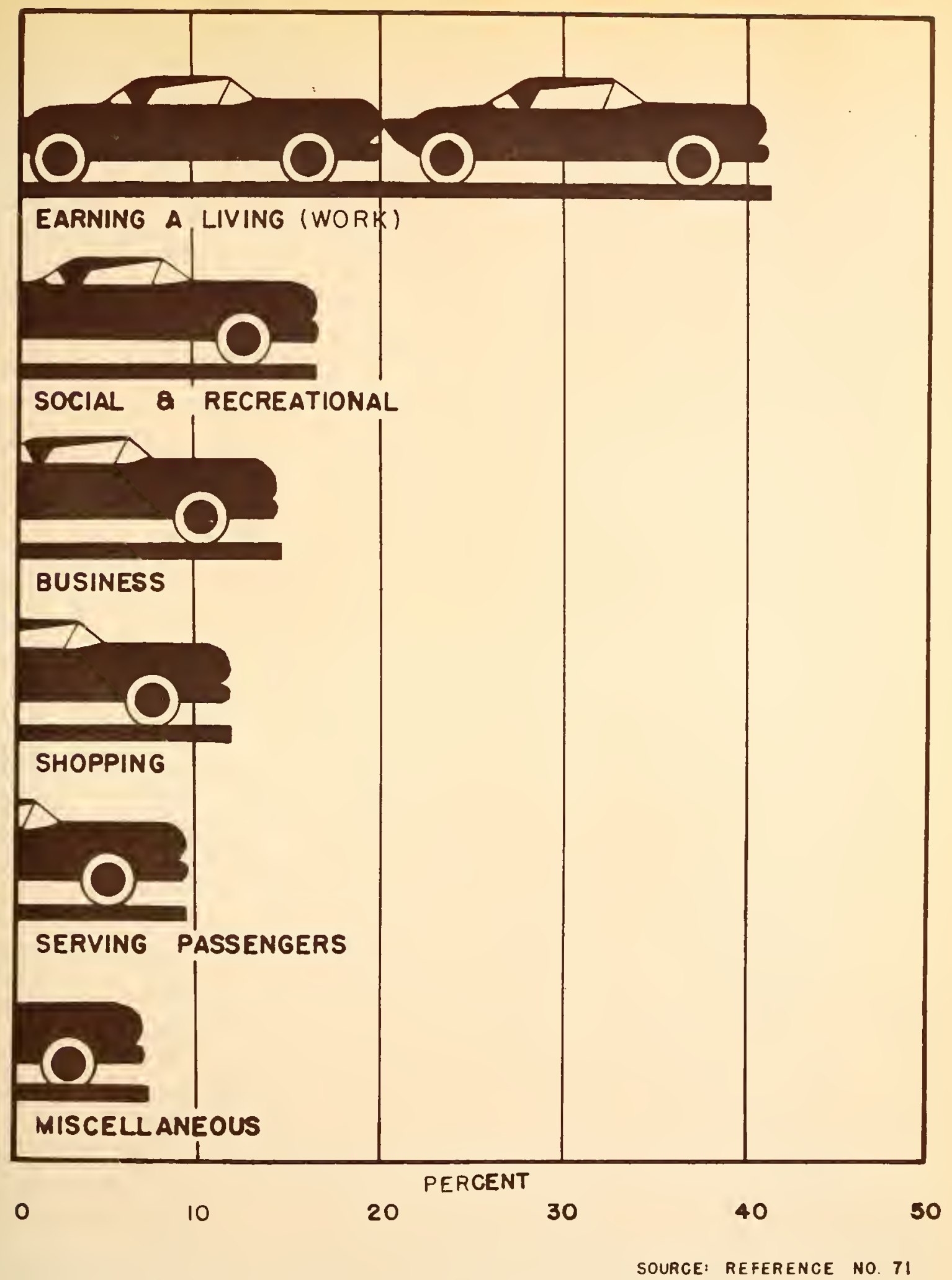

HOW PASSENGER CARS ARE USED

FIGURE 16 


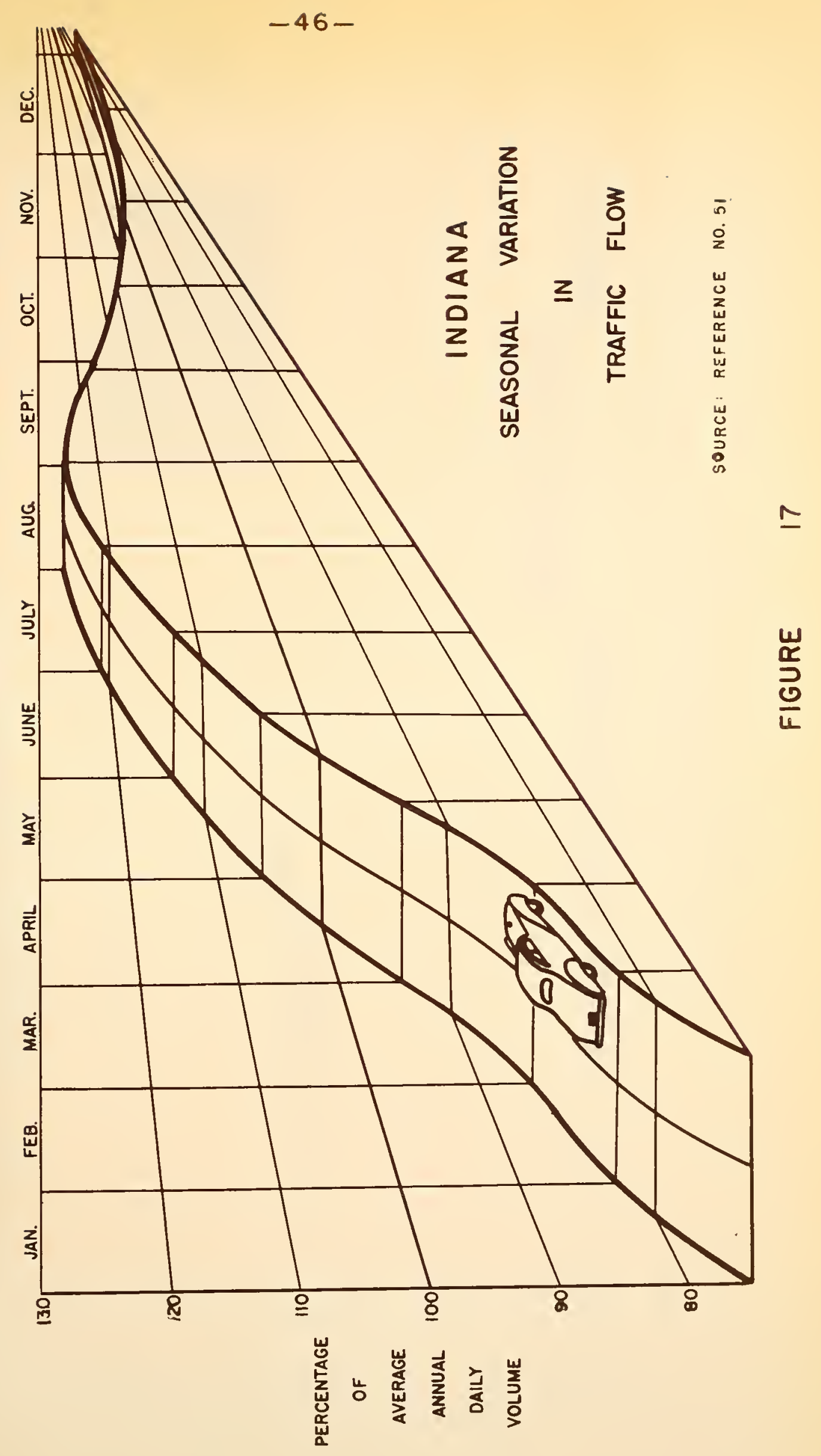




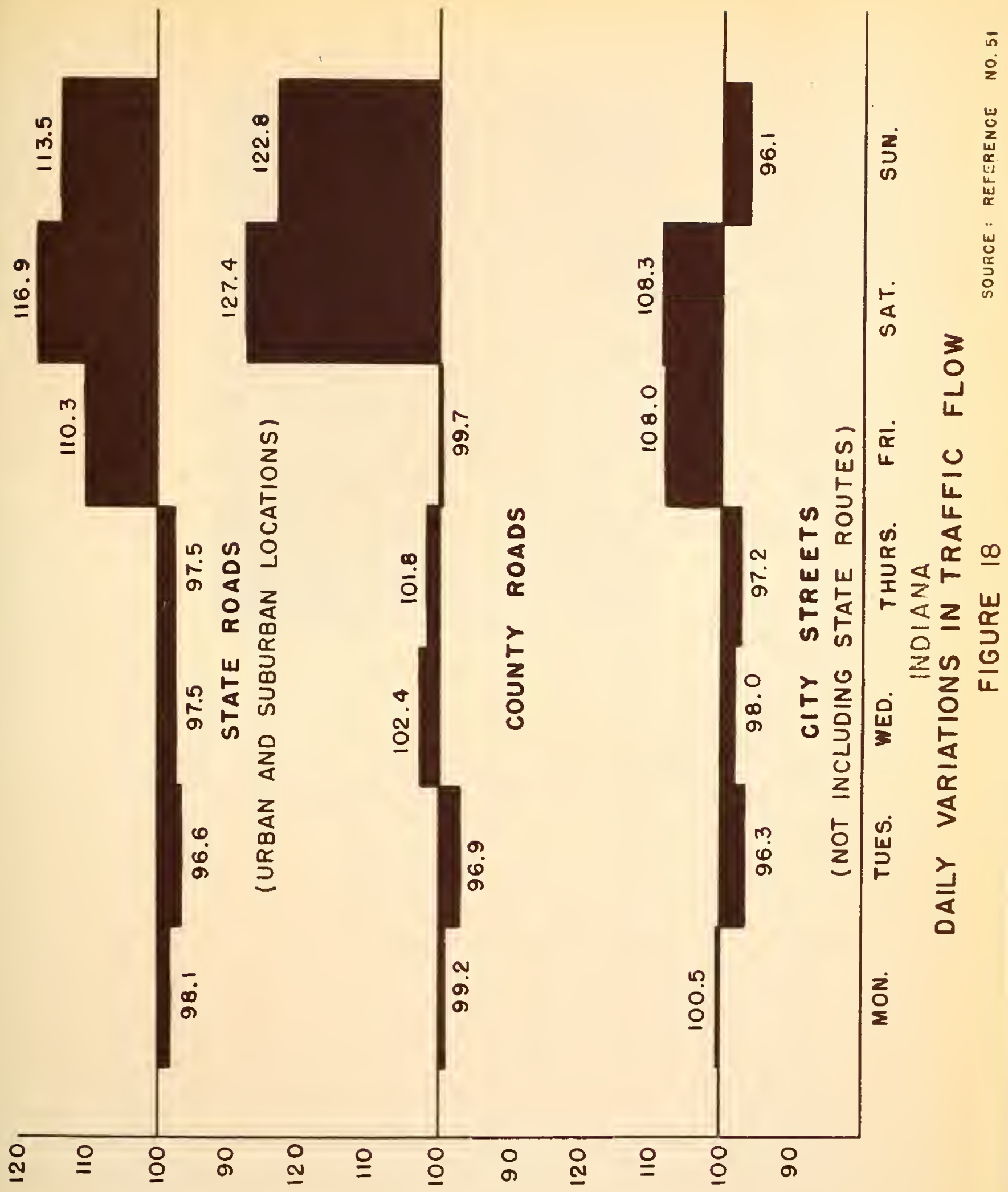

$\exists$ $コ \forall \exists \wedge \forall \quad \wedge \forall 0 \times \exists \exists M \quad 」 0 \quad \exists ९ \forall \perp N \exists \supset \forall \exists d$ 


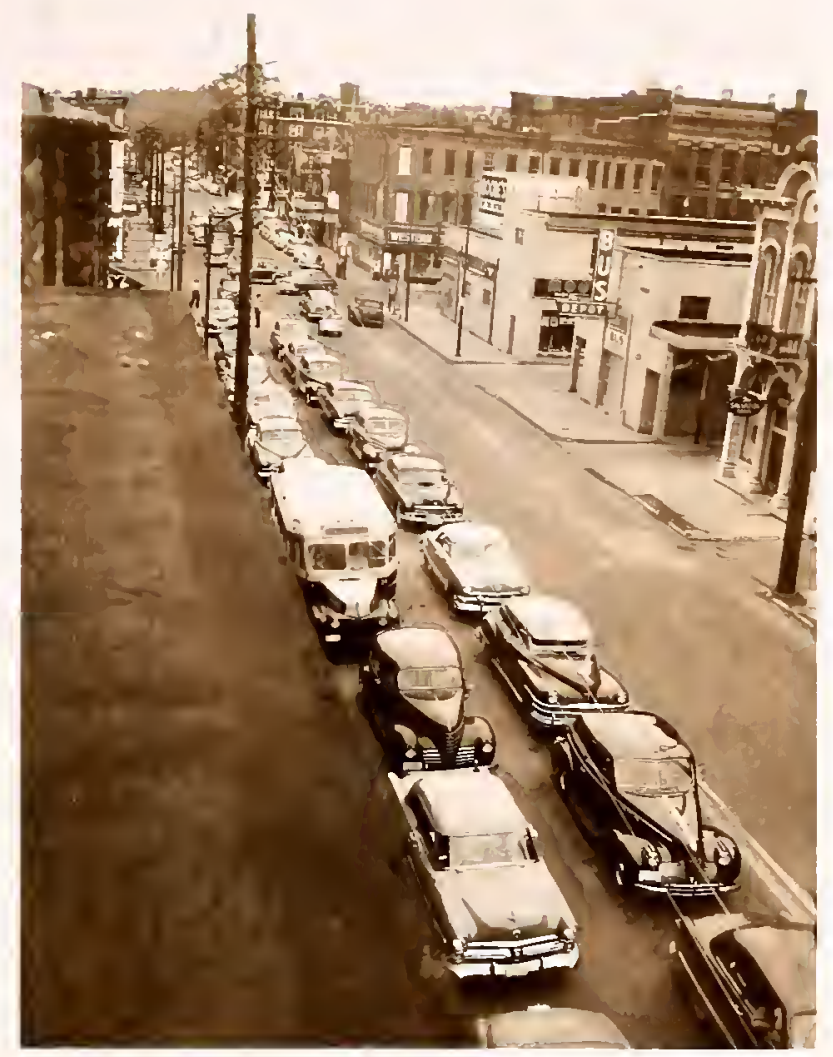

In urban areas peak traffic volume is reached during the 4 to 6 P. 


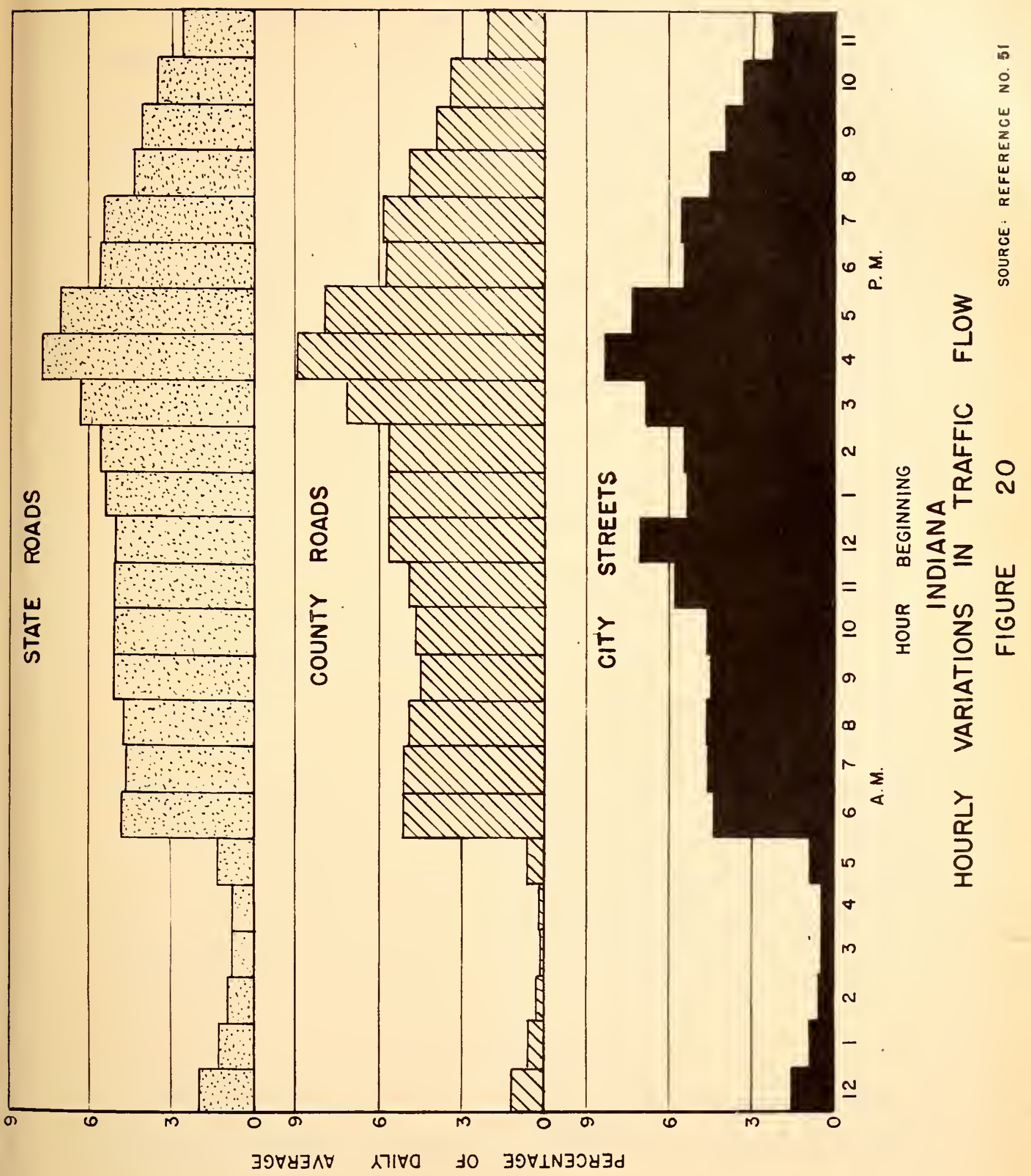


Where Friday is the eecond highesto

Hourly varsationa in traffic solumes during the day are much more pronounced then daily or seasoral veriationso Un city streets less then one-rifti of the total dafly trazel moves during the tenchour period between 9 porso and 7 a.m. The highsst folunga are from 4 pomo to 6 por. whon mogt people are returning home from work $(51)$. Luring that poriod traffic is as unch as 68 porcent above the average hourly volume and 16 times bigher than the rainirus arly norning hous volure (5i). Irforo mation regarding variations of traffic volurie causad oy those anc other factors is yitally laportant in determining the sxpocted traficic loads on all classes of highway.

Indiana ${ }^{\circ} \mathrm{s}$ roads and streets sorm a connected syaten which provddes routor to all parts of the state and adjoindng staces. Travel betweon the ifferent origfins and destinations produces taslous amounts of traffic on the aeveral classes of rosdway into which the aysters is divided, and In the eeveral geographical areas of the atrta.

A vary $2 a r^{\circ}$ proportion of the rural travel is carroled by a comparatively arall part of Indiang's rural road milcage. The gtates maintalned rural and urban highway systen of 10,600 miles, reprosenting

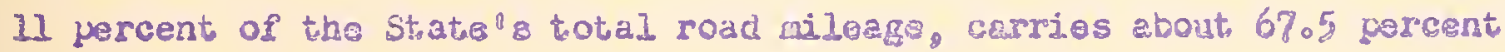
of the total travel in the state. valy 17.5 percent of the total travel occurs on the County hoad Systen of 76,000 3iles, which reprenents approxdmately 71 parcont of the total mileage $(40)$.

\section{Present and Future Travol}

The msgitude of the total traffic movement in Indiens is detero mined by threo factors: population, density of motor vehicle owneranip, 


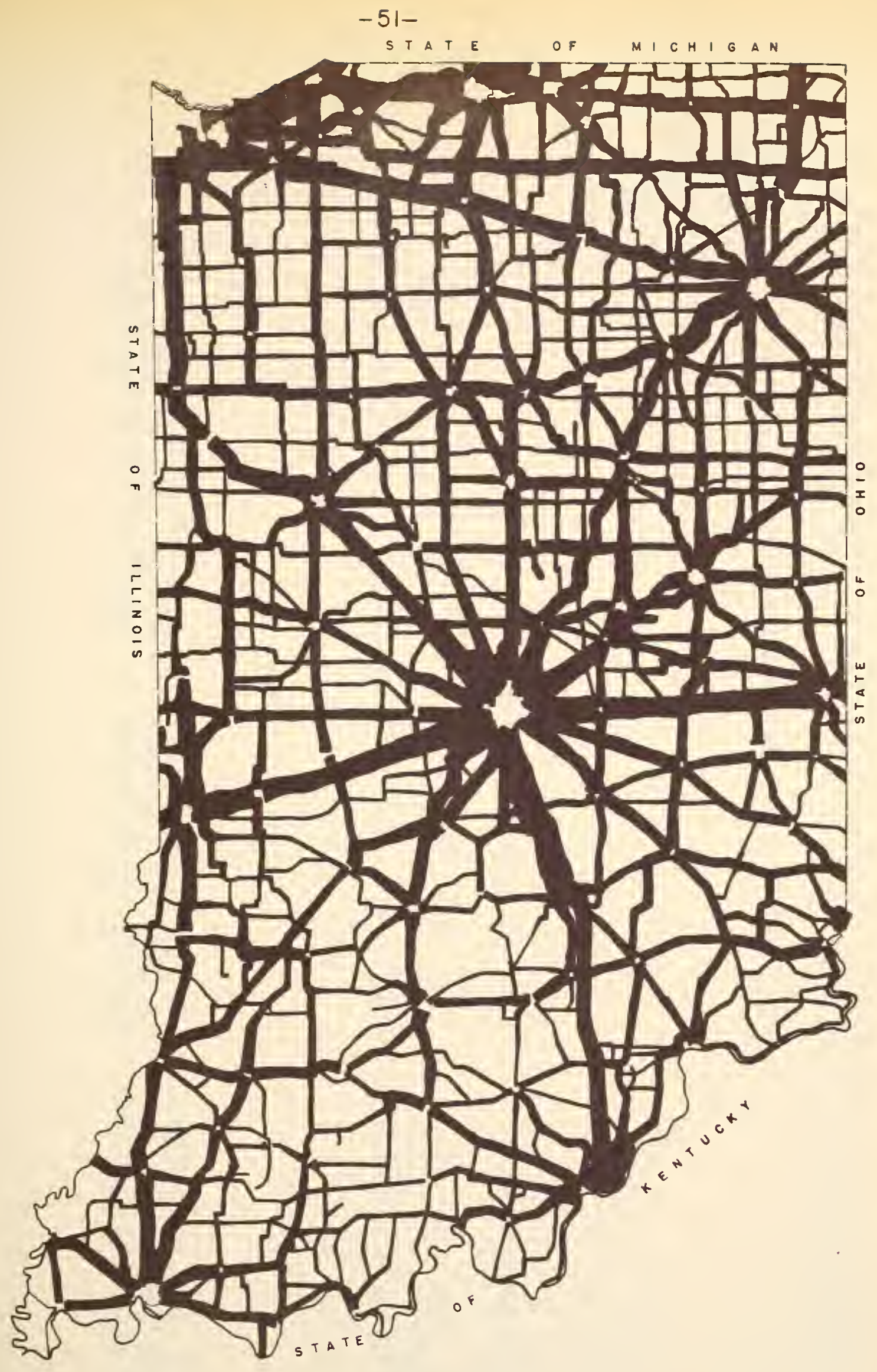

FLOW OF TRAFFIC ON

STATE HIGHWAY SYSTEM. 

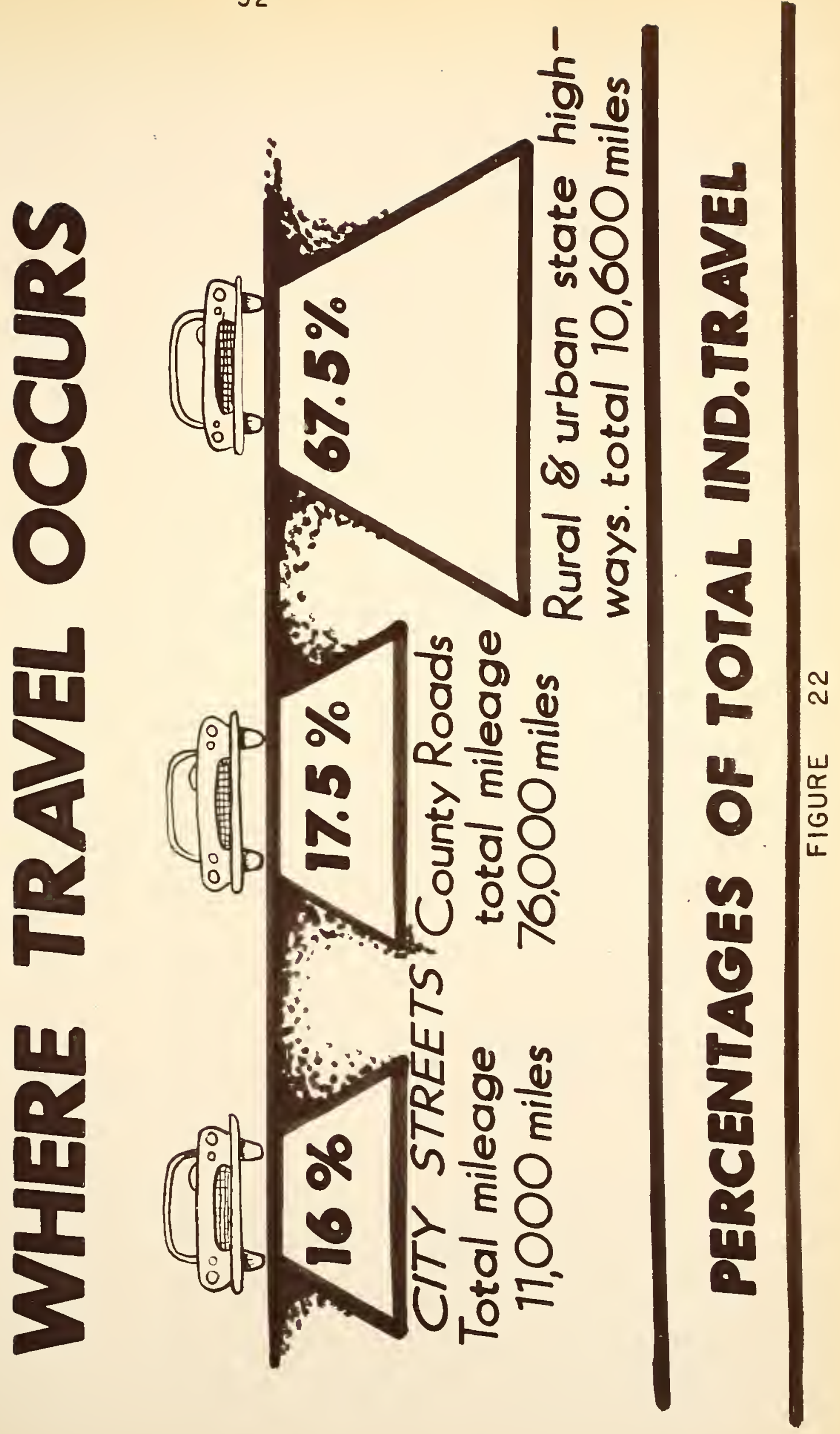

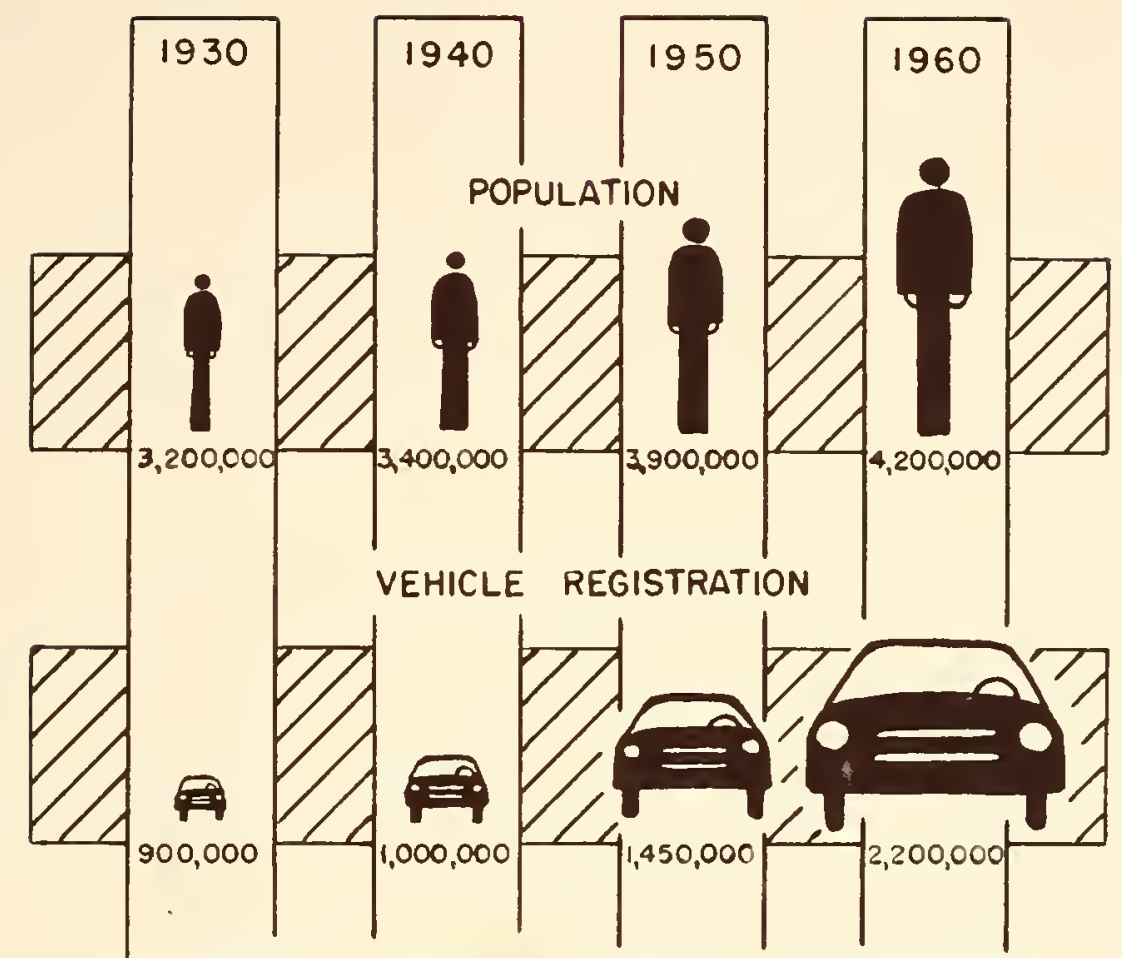

AVERAge gasoline used per Vehicle

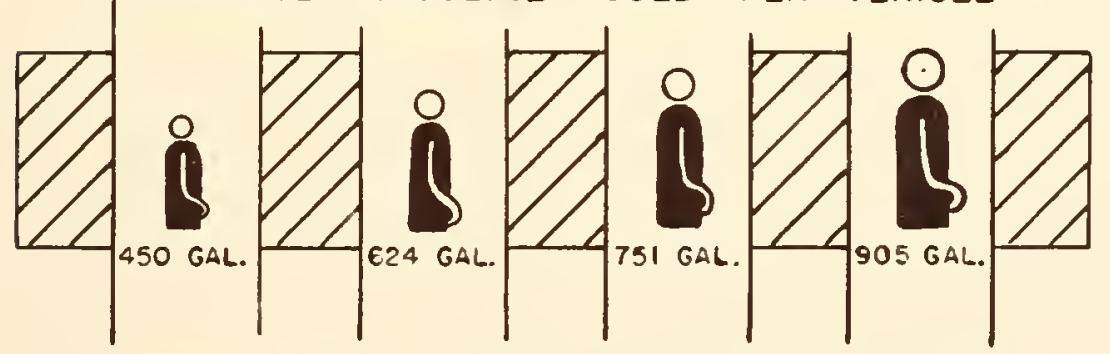

ANNUAL TOTAL TRAVEL IN VEHICLE MILES

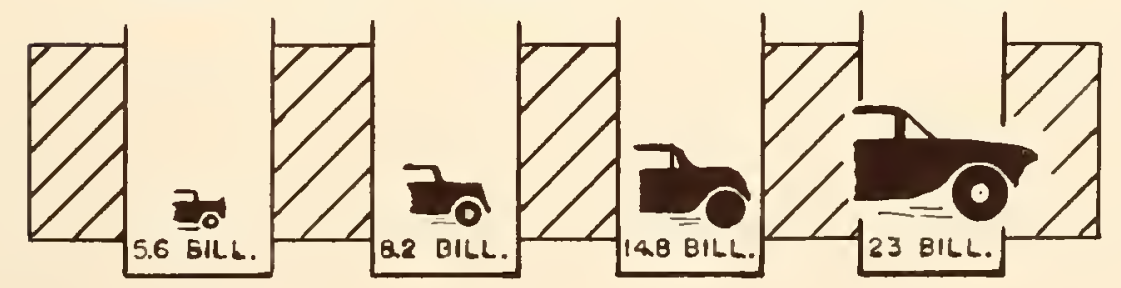

GROWTH OF FACTORS AFFECTING TRAVEL

ON INDIANA'S HIGHWAYS

FIGURE 23 
and milos driven annually by the averaje vehicle. As a group, these factors can be used to estinate the toial. zoluma os stateowide traffic for any given period.

Analyses of past and present variations in these basfc factor: revea Itrends wich can be projected into the future. Such projestione

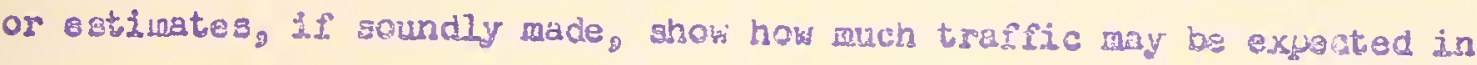

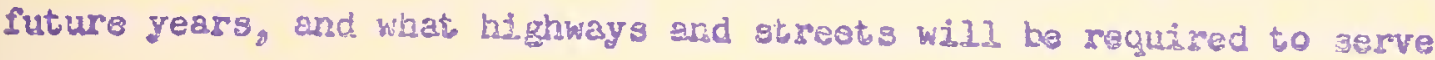
and accompodate this trafico for highuys, due to the iffe of highay gurfaces, estingter for 20 to 25 yaars in the future aro of particular value.

The 1950 census counted $3.934,224$ porasoss in the state, and it is eotimated that tho 1975 population will be betteon 5,200,000 and $5,900,000$. Since 1900 the pojulation of the United states hag nearly doubled. The population of Indiana has grown senzewnat slower, but jit is reasonale to azsume that tho ratos of increace of pojulation for Indians and the Unftod States will have the same ganoral trand during the projocted per2od to 1975. The grvatsat Increase has bean In urban areas. Indiana, today, has more than twico as many poojlo as a compars able average area of tire United States, but only about 87 percenì ea many as the bast jorth Central area of the Unised States (70)。

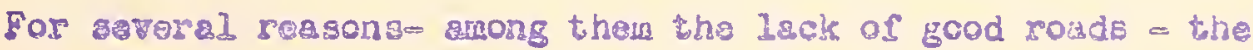

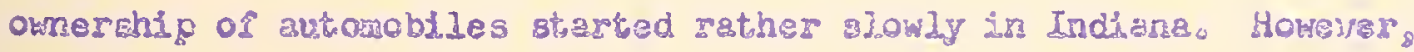
by 1930 the boom of the $20^{\circ} \mathrm{s}$ had increseed the number of notor vahicles owned In the state to 875,000 . Although thera ware desreasas churing the depression end forld has II, the uvtsard trand continued and by 1955 Indiana registration wes about $1,800,000$ vanicles. The number of pero sons per motor vehj.cle has been reduced from about 3.7 in 2935 to 2.25 in 1955. For the Iattor year tho comparable ratio In the Undted Statea Was 2.8。 


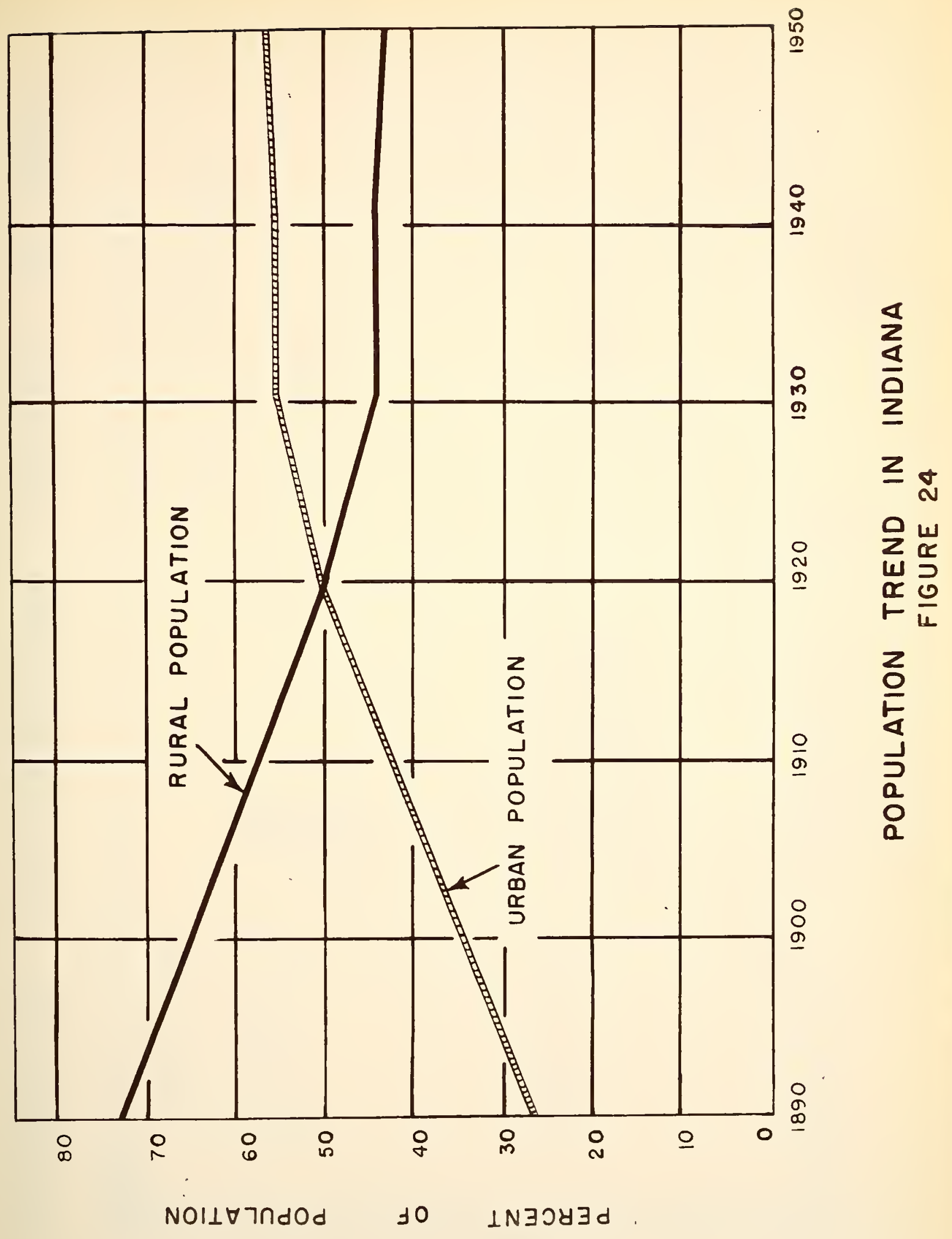




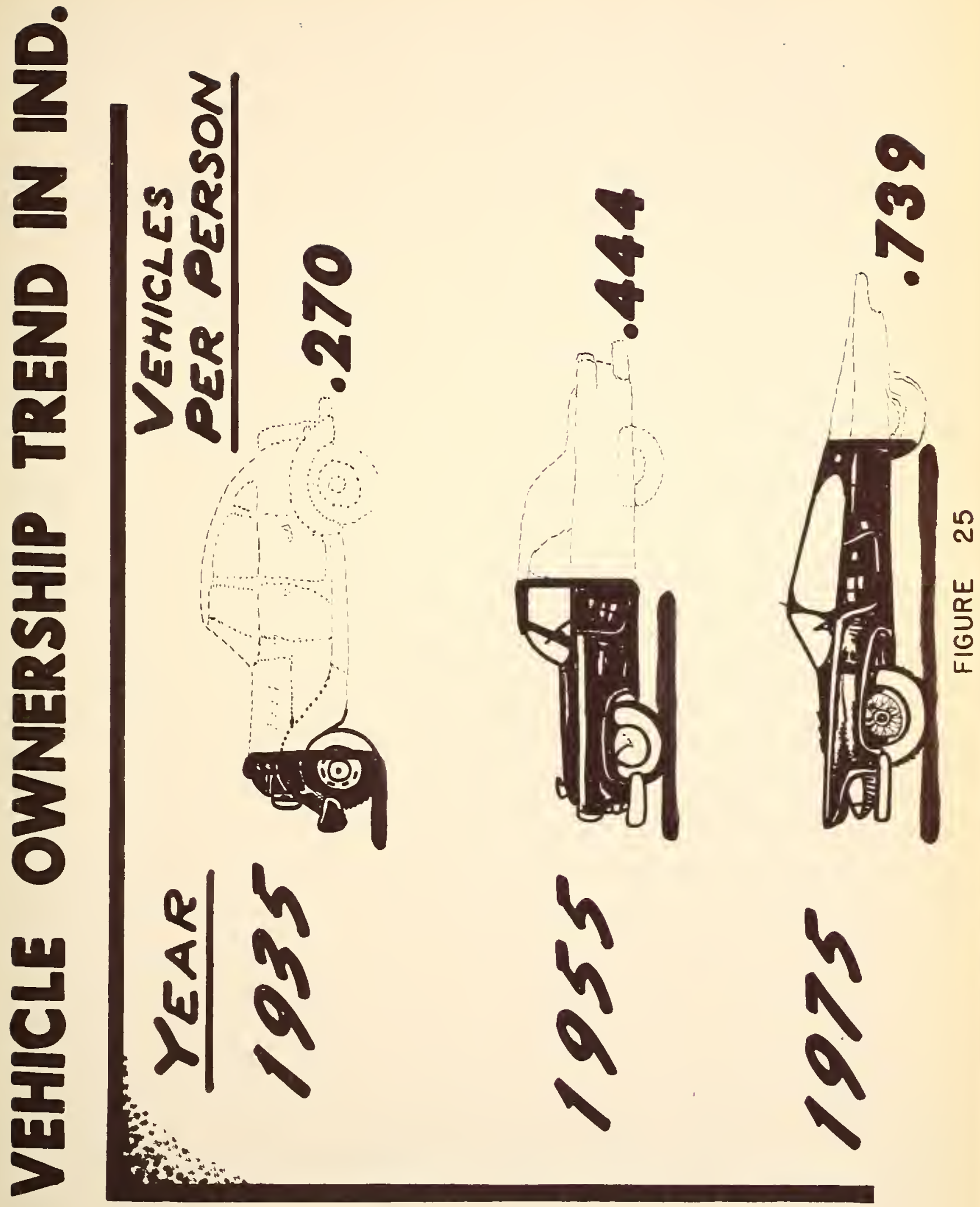


In view of the economic progress of Indiana and its people, and on the basis that highways and streets will be further improved, it $1 s$ predicted that motor vehicle ornsrship will continue to increase at an accelerating rate for the next 20 years. It is estimated, thorefore, that by 1975 the ratio of vehicle ownership will be nearly 1.35 parsons per vehicie. This estimate or ownership density indicates that there will be approxinatiely $3,380,000$ motor vehicles registered in the state in 1975 or almost double the 1955 total.

The average individual vehicle operator has diviven his car or truck an increasing distance each year. Estinates based on analyses of motor vehicle use data and on the notor fuel used annually for highway travel indicate that the average distance traveled by all venicles was about 10,000 miles in 1955 (20). The data of the last fev yoars indicate, however, that this figura is now nearly constant. Ithe averago travel for truck and trailer combinations, however. is increase ing. This incroasing traval by heavy vehiclos is important bocause the size, walght, and operating characieristics of those unfts creato special trafilc condtions and design requirements.

In this study an estimate of traffic was made from 1955 to 1975 for the stato Highway System. It was derived from the projecticn of growh trends as determined from the records of the fermenent counting 3tations in Indiana and is incicated by the lower curve on the accorspanjing traffic growth chart $(74)$. A projection derived from the three basic factors of traffic generation, - population, vehicle registration, and fuel consumpticn o gives the upper curve on the trafifie growth chart. For the purpose of this study, the lower curve will represent the average growth and the uppor will represent the upper limit of growth. 
Computations of the projected values for the lower curro indicato that in 1975 total highwag traffic in Indzana will bo approsimataly doublo that of 1955. This estinste foreshedows a tremendous expansion of the traffic load which the haghthays and sereets of Indiana will be required to carry in the years ahesdo 

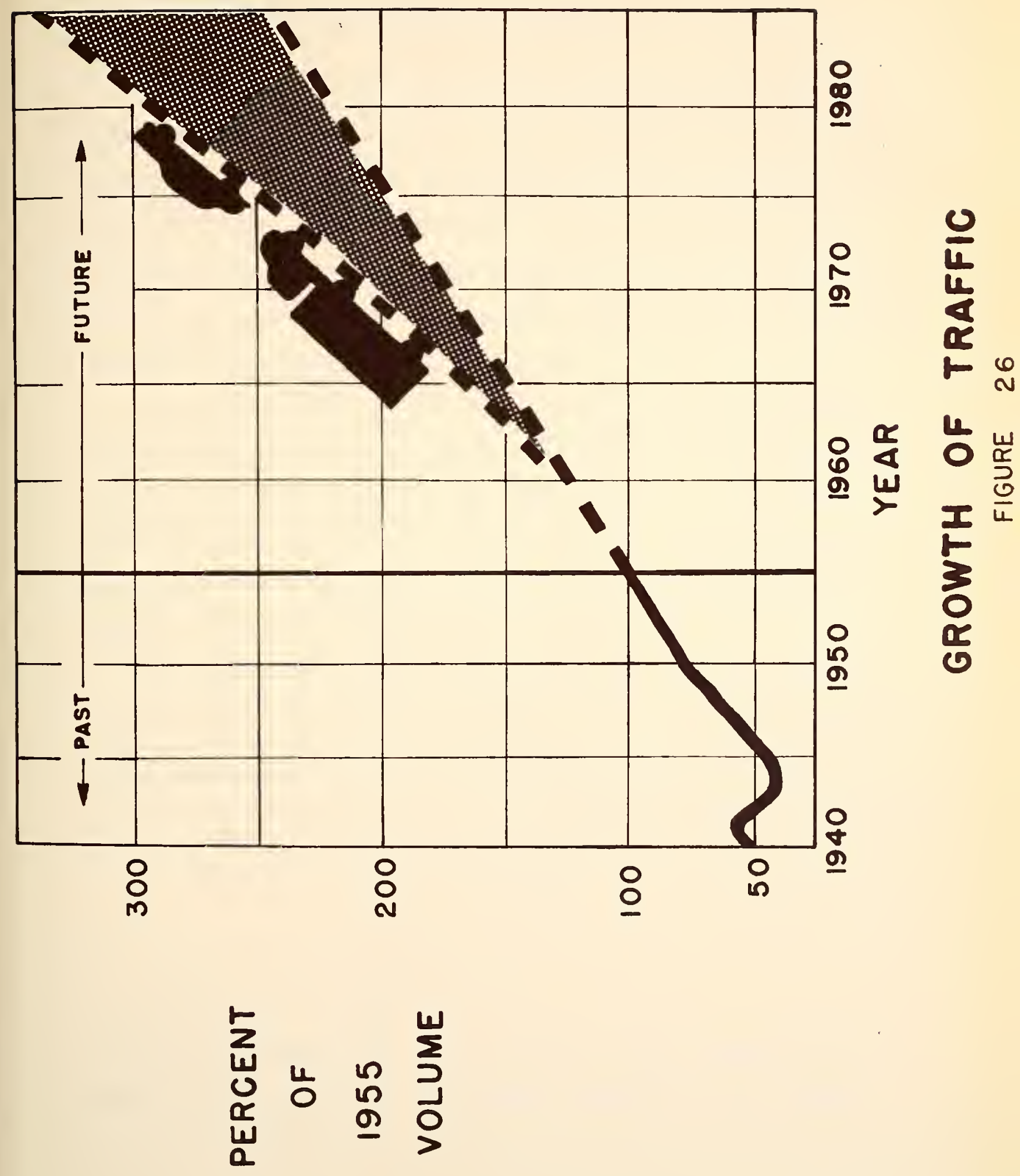


\section{Chagter IIJ \\ HIGHWAY CLSSSIFICAIIUN \\ Cjsiafichtion and Its Purooseg}

HLghway clagejifcation 28 of bosic importance in the propor devo elopnsant of Indians " roads and streets. Classifleation is the prosess of groupling poads and styests according to the desires and requiraments of trafic. Such systenatic grouplng is essential in dealing with problems of jurisdiction; flscal responsibillty: end the developinent of congtmetion, and waintgnance standards to permit uniform and Bconsulcal devolopwert of an offlcient alghky aysteq.

Urdarly clasaiflcation of highusys regults in economic bangfits to the highway user. The develowment of highway classifucations how gver, in faced with serjous problems and handicaps. In mant casas jightsy adinistictore exe not sware of the need of classification, and In meng other cases propar classiflcation is hinderod by political pressures and lack of undarsterdirg and information.

Soveral factora affecting traval chmsactaristics ware previcubly discussed which cause different psttorns of road and stroet usago. In general varlous traffic conditione generato diffarent, well-defined patiorns of travel which uauediy can bo classified into four groups (59):

1) Interstate interest

2) Statoside interest

3) Compunity interest

4) Local interest

Each group dewanda a special typo of service from tho highway becauso trafflc roquires that different demends be fulfliled in oach cass。 
Interstate highways nest provice an integroated system of roods over the ont1re United Statea, because they mast provide service of interest to the entire nation as woll ag to the individual stateg: Such a Bystan of highwaye raset also provide for sprefial serwases during national emergencios。

Highways of staie-wide interest provide facilities for truved betweon various areas of the state (59). In many respecte the travel requirements on this typo of highsay will be similar to those or the Interstate systom. It is rather difficult to maiso a definite distiaco tion batween thase two highwgy typss because they provida a similar guality of sorvice. Moro mileage of auch highways will be required than for interstato travel, however, and there 10 loger need for $1 \mathrm{~h}-$ tegration into a national notwork.

Highweys of ccrmanity interest are those fecilities which hasdle trips from one part of a conrunity to anothes part of the saide coja munity (59). It Includes combatior travel from large citios to mural aress, travel from farm to market and travel from farm to farm in difo ferent arsas of a comemuityo A cormuntty 18 usually limited to a dec finito arsa about ths size of a county。

Roads and stioets of Iocal interest proydde access to lando In the rural aree the local systan provider access to farms; while in an wrian area, It provides access to residential, connarcial, or industw rial propertyo

In addition to the primary travel function of the various tyges of highway, the highway also provides othor services (59). For example, a highway of state isterest may also provide sarvice to local and comanity travel. In the cities much of the comanity travel is 
carried on state highway extensions which pass through them。 Highweys of comunity interest also cargy much locs I traffic。

However, each of the basic types of highway deseribod carrdee traffic which is preaoninately one of the types of travel. How a highway is predominately used is usually the as slc factor in determin= ing highwiy clastification (59). Traffic volume, in itsolfo is not necessarily a determining factor; however, the volune of traffic asd other factors give additional information concerning the predominant use of the hichway.

The organization of highways into systems is a relativoly aimjle matter after the classification procedure has been completed. 'Shese systems can be essigned f1ecal support from the city, countyg or state jurisdictional unit depending upon the predominance of treffic interzsto Hach agency is best suited to handle it's own particular financing prow blems because it best understands the problems and thoir solution. Standards of design, however, should be selected for esch class of highway so as to assure uniform standards of aervice for all parts of a state.

\section{Existing Systoms in Indiana}

The more than 98,000 miles of roads and streets in Indsana are dirded Into three adrinistrative systems ostate, coutty and city $=$ created by legiolative action. There is, however, a slzeable degree of overlapping of functional uses of the highways in thoge systang. ospecially on the State Highway System.

State Highways

The loglslativo power that resulted in the Highway Act of 1919 establiahed tho legal framework for the State HIghway Sygtom. By 1920 
neurly 3200 miles of this aysten had bean established (13)。

The miloago atoadly increaesd unitl 1940 and has boan on a gradual Inciease since, emounting to only a fow miles each yoar, adsce that tine. Today the Stato Highwey System is over 10,600 inides in lesgth。 Noet of the rapid incresse in state highway mileage wes causad by the logical demends of freater yuartitios of tratific wiaking to travel more convendently to differant arsas of tho atato. Hany ajles of the state syatem ars now urban ostensions pagaing through clties, and many by-passes have been constructed around clties in the past 30 yaars. Many miles woro also added cecause countios desired to bo rolieved of soud which was a maintenance burclen or desired \& higher typs facility without disect expense to the countyo Over the yoass many miles of higivay heve poen added to the state syaten which grom s functional stendpoint, should not be these. it has baen estinuted that porhaps as many as 1,000 miles of highway are not required on the present stato systen; nost of theso roado primarily carty comunity= intorest trafilco

The Federal Asd Highway Act of 1944 yrovided for the eatabliahw ment of an Intaretato Sygtem of Highways which would connect major centers of population and estabijoh a strategic networy of highways for national defense. In 1955 the urthan axtensions of this syetem were established, thus comploting tho network. Indian ds regponsible for the construction of 3100 mtes of Interstate Highay including urban conatruction in Irdianapolis and the Calumst aros.

Fedorel statutes since 1916 hevo contwibuted to the eatablighent of a rural Stato Primary and a Stato Secondary Syaten, along with tho urban extensions to thoes highways throughout the state. The state 


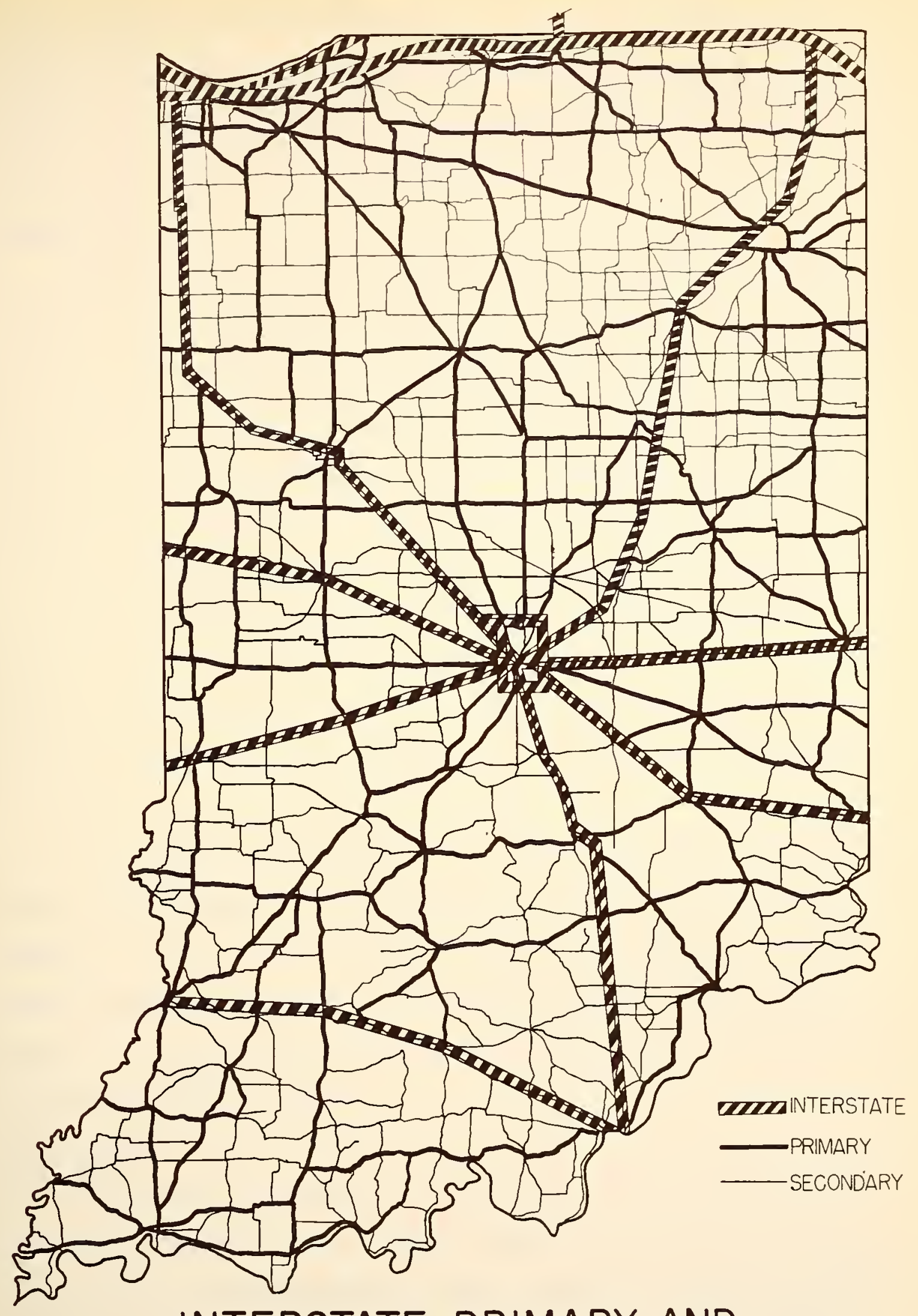

INTERSTATE, PRIMARY, AND

SECONDARY SYSTEMS 
trimaxy Sygtan* conalats of 3600 milsa of the nore important rural highwy roukes in the atata and the State secondary Syster consiats uf 5400 miles of tive 1098 inportant rural state hishways. Urban extersions to the rural systoms amount to ebout 500 miles.

\section{County Roads}

In gonsral, no attempt has been made by the countios in Indiasas ercopt Allen, Dubojs, and Jay Counties, to classjef ihsis roads in torws of functional daportance. Tho 1955 study in Allen Gounty, conducted by the joint Highway Kesaarch projact (7), clevsified county ruads into primary, acondery, and locel roed systems. whis atudy was performed to outine the procedures so that other counties could solvo tnedr road clasification problem on an objective and scientific basiso

Very few miles of the 76,400 miles on the county systems carry traffic in excess of $1_{2}, 000$ vehicles pow dajo post alleage carrise lege than 25 vehicles par day. lieny of the highly travglod coado carrylng Local traffic waro Incorporated into the state 3yster dinging the $1920^{\circ} 8$ and $30^{8} \varepsilon_{0}$

Some of the more imoortant county highways have boen olifiole for Federal Ald Socondary Funda since 1944. Uvar 10,000 biles of county highways sro prescnt Iy in the Foderal Ad Secondury Sybtema However, other than this clasification, tho countias have not developed and followed a mitable hishwy claseiflcation program. Tho urgent need for classtidication Lo obyouro

\section{City stroeto}

Thera are oyer 11,200 aldes of stregts in the incorporated cities and towns of Indiana (52). In emaller cities, most of the importinto city Etreets from tho standpoint. of usge have been classified function flly because they ccmorise the uroan extensions of the State Highway 


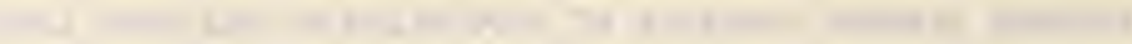

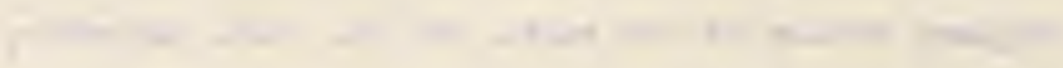
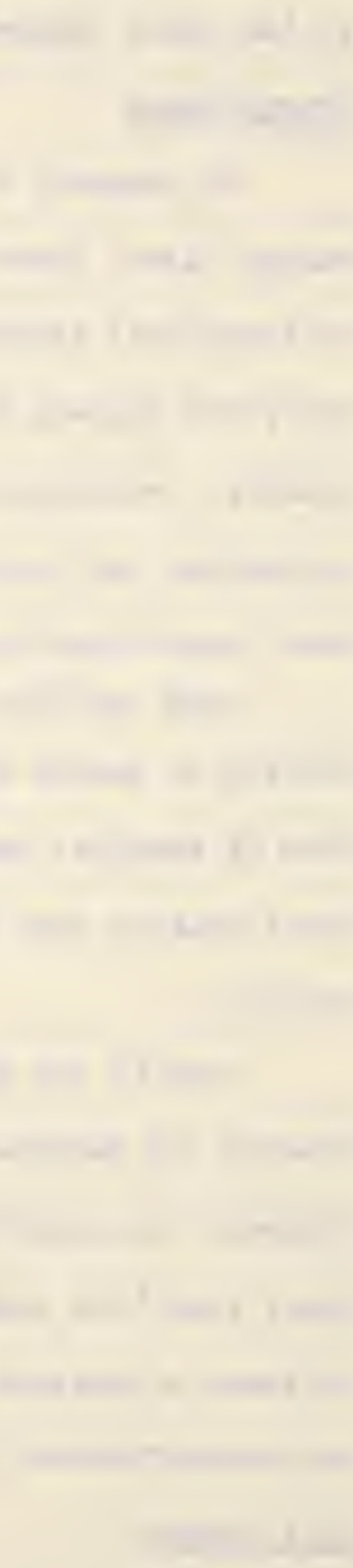

- 
Syatem. Of course, many of the 1mwortant streets in zarger citfea are also on the State System. However, many of the streats in larger cities which carry substantial amounts of traffic aro aot on the state byatero Several of the chties in Indiana have done an excelieai job of classifying their streets。 Some have adopted the findings of city planners in the establikhnent of nejor thoroughefare routes. However, meny cities have done little in osjanizing trigis street systens in a logical and orderly manner in eccordance with thalr functional use。

Many streets, espocially in larger cities, carry trafíc rolumes which are nearly equal to the trafíc carried an the urban- atato hivblwy extensions. These streets also must carry heavily lcaded vehicles and other special vahicles necosary for proper sorvice to the population of the cityc us the other hand, masy streets are used primerily for landeservice functions to serve those people in the hares winj ch sbut the streeto Some streets also have small bughnesses and industry abutting them in addition to residential proporibio

\section{Eow Clasification Cas be Dong}

Although tho present State Highray Systen is classified, there are many shortcomings in the present System. The Systom has expanded without adequate control and now raquires a thorough jeviewo sone Foade now on the stats System should be returned to county jurisulatiun bocause they predowinately asve communty-interest traffic。 Perhaps other roeds currentiy under county jurisdsction should be in the state Syetsm. In recont years scientific mothods, which do a better job of highway classification, have bean developed oy highway engineers and adrinistrators.

Classification of county roads and city streets is nore difficult 


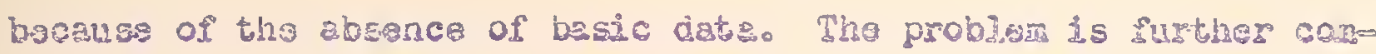
plicated by tha fallure of the couthes and citios of Indiana to doyt

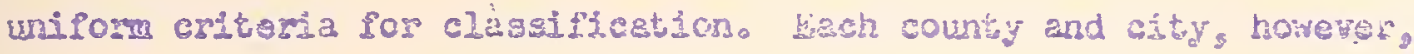
has speciflc probloms and degres which do not complebely conforis to an establizhed sat of rules for classifleatlcu.

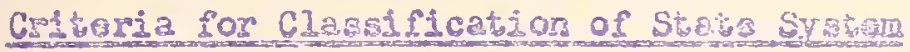

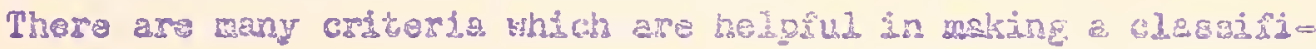

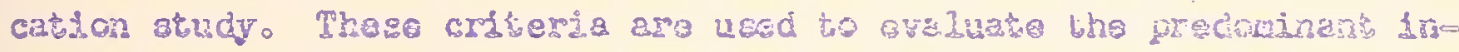

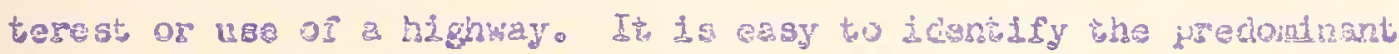

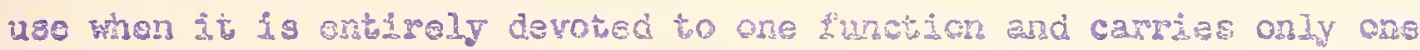

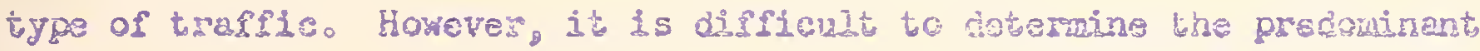
use when the highwy carise traffio with Tarious levols of Lateresto

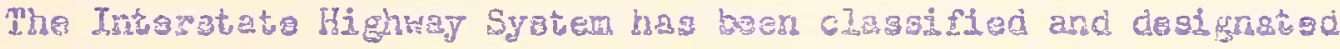

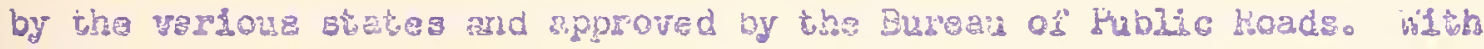

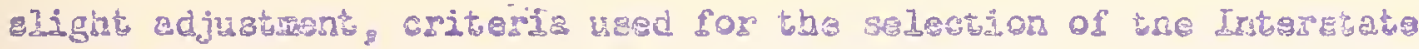
Highray Syatom cen also he used for the Stato Syatrm. A highway gystom of atatowide intarest should do tne following $(59$ )

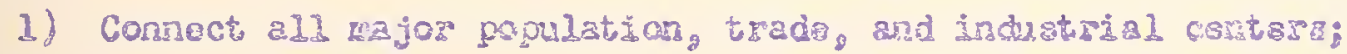

2) Connect major highwy of adjacent atstos and forn an inhegratued 3Fstare within the state;

3) Connet a11 seats of county governongh:

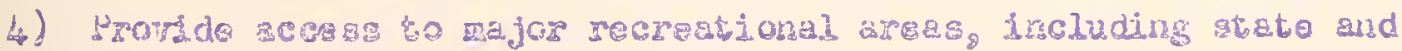
national pasis:

5) Provide accass to major state institutions;

6) Provide scress to rajor torminale of cthei trangertation facilities:

7) Have a volune of traffic on each highway that je sufficient to 
economically justify the inclusion as the highway vitinin the รyำณ?;

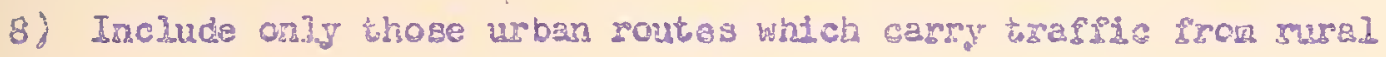

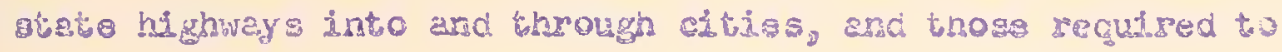

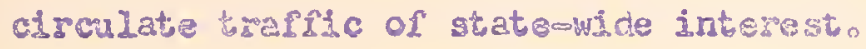

The highay ahould follow tho most economical and fismible goute betwegn cities or other aroas of attraction ln the rural areas. In

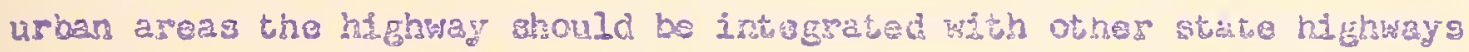

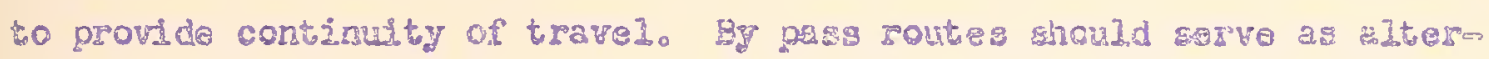

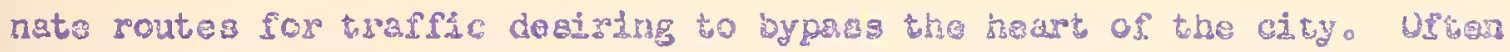

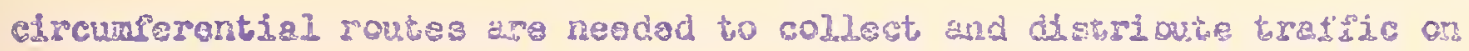

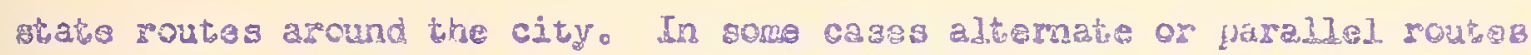
should be added to the ayster to provide addithongl capschty to sirve tho overglow of trefsico

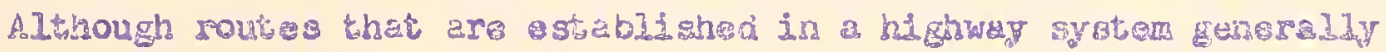
Barre the same trafile functionaliy for an Lnderinite pertod of tine, Lto js nocesamy to reclasaffy cons highways as condżona change. Economic expansion of agrculture and indugtry, rajgation of population, sono struction of now trangportaton facilities, and uasy other sactors

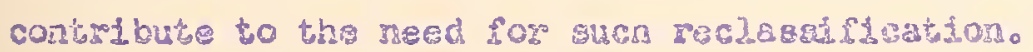

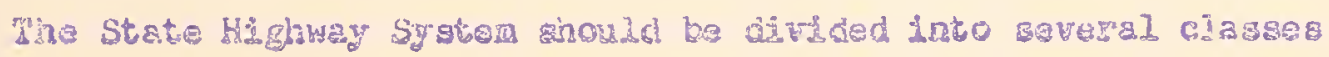

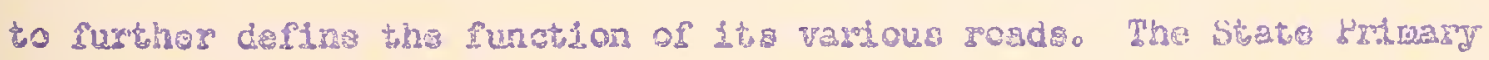
System should Lnclude long distance goutes connecting every purt of the

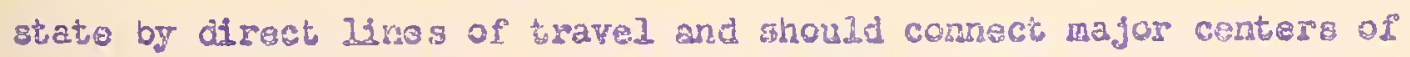
population and vashous rezional areas of tise atate. A primary routo alco reeds traffe to the Intergtate Syatora. 

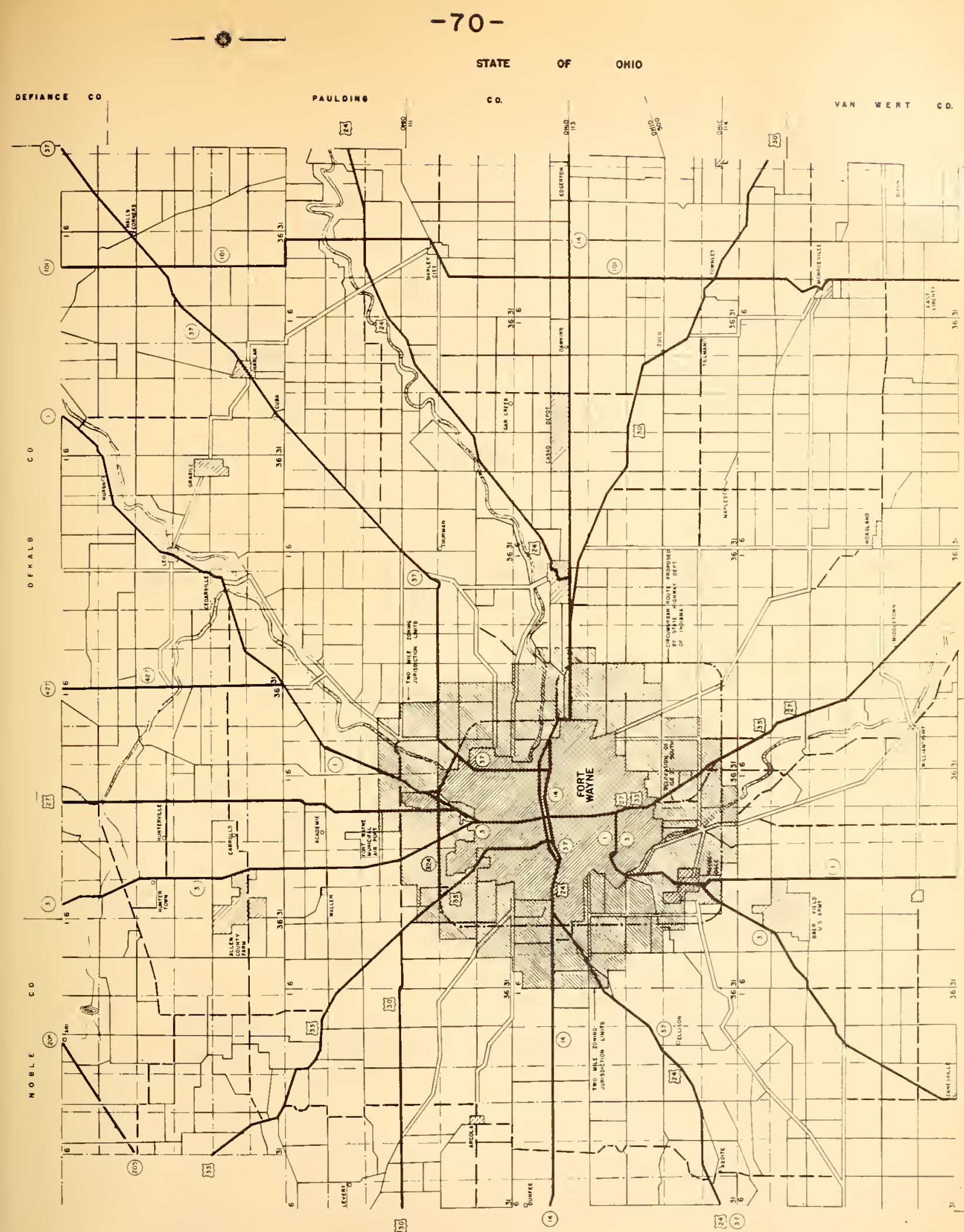

逐

()

anter eo.
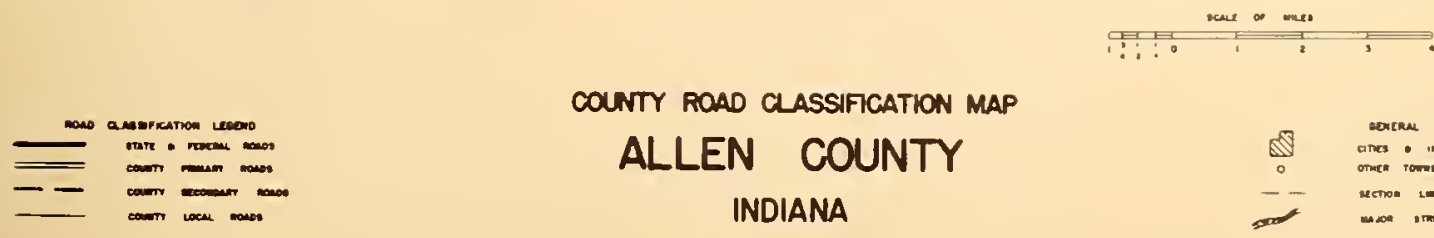

COUNTY ROAD CLASSIFIGATION MAP

ALLEN COUNTY

INDIANA

Dowt hionwaY Reseanch mosect

Punde unveneity

FIGURE 29

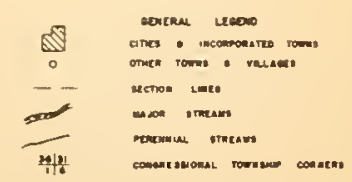




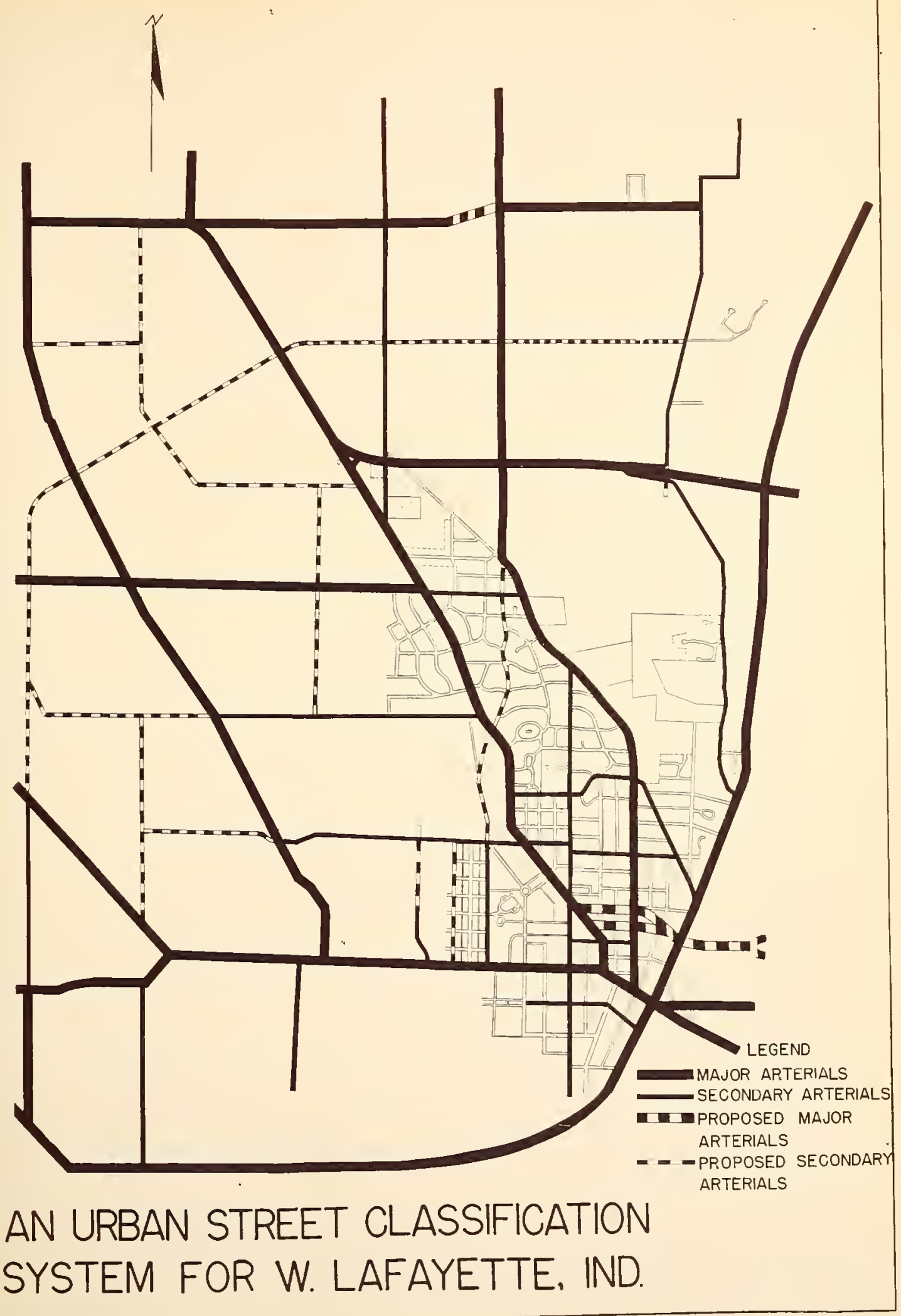

FIGURE 30 
The State Secondary System shovid feed tionfic to the rminery and. Intesatate Syeters and ehould conect sraller population canters, public Institutions, atate parks, ard recreational dreas. This dyetem dyo should bo used to kntegrate and coinect yystems of higher clissisticetion。 In some cases "gtub" secondary highweys showld be permithed if they provide access to state perts and institutasoso

The Urban Stato Highuy Syatem ahould form the thiscingison of the stiate System. In all. careg these urbar extenajons ahould be part of the cify arterial system out should be classiened as purt of tne stute Syslen because thaj prodoninarat use j.s of statemide interesto County Highivas

Gritoria for the selection of tae verious clusss of county highways can be developed fron the criterda for a stato Highay systeno The scope of these criteria must de raduced to countj ind

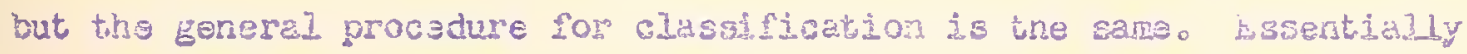
county roads should be ditided into three toneral classos: ruinerys Secondary, and Local Seryace $(7)$.

The Promary Sybten should be the wogt imgortant pouter in the County Sjaterlo Local industry, milk distributors, school buses, pestal

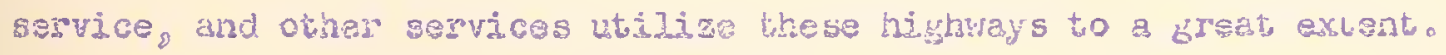

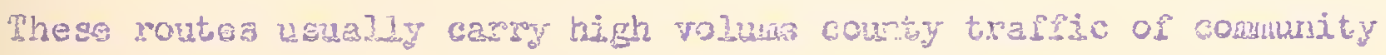

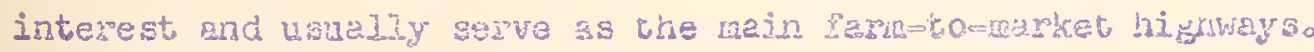

The Secondary System should act as feeder Foade to the prinary routes. These roads w11 also serve the counties as lailk, schoul bus, and postal routes. They will usualiy carry relarively lesg traffic wolume thar the Prinary Systexto

Tho Local Service System should serve prónerily locel property 
owners by providing them convenient access to their property。 'lraffic volume on these roads 13 amall and in many cases will be only a for cars por dayo These roads include the gredtest number of miles of roads and streets in Indiana, but provide the 2east uaago from tne stabdpoint of the number of vehicle miles traveled.

City straet.s

It 1s very diffcult to devise gororal princiules for the classio fication of city sireets because many complex problems are involvad. Each locality often has specific problems which imst be solred. However. some of the broad sopects of claseiflcation are discussed in the follow ing paragraphso

The micipal streets have oeen clasgifled into two general systems for this study, arterial and sosidertial. In practice the arterial system is subdivided into two groups - the Prinary arterial and the Sacondary Arterid. Generalidy, the arterial sybtem connecto focal points of interest wthin a clty and orovides for movesnat of trafic to and from different areas of the city and acrosa whe cityo The residential or local stregts primarily provide access to abutting property ongrs and serve as feedors to the arterial streets.

\section{Results of Ciassifleation Study}

Table I shows the results of a study of the actual mileage in each classification of the state systems ano the estinited mileage in oach classificetion of the county and city systems.

\section{Conclusions}

All of the roads and streets of Indtana need to be classifled on a functional basis. This is especially needed for the county and city 
nighways. Ure of the basic steps in the proper and eflicient acininietration of the highway gystem is adsquate clasaification. Some of the obvious advantages are es follows:

1) Classiffcation determines a foundation for the establisnment of longerange fiscal polficy:

2) Clessification establishes a basis for efficlent managenent and intorgorernmental coordination;

3) Highways aro integrated into a complete systera and are also grouped with those highways which ehould be under the garne jurisdiction becaus of the typo and demands of highwey zarvice:

4) Equitable distribution of higinway costs, according to tha service zendered is provided;

5) All highways requiring the same level of technical competence for design and conetruction ara groupad together;

6) Assignment of responsiblizty on various classes of roeds to the most appropriate agency fis made on a sound basts. 
Tablo \&

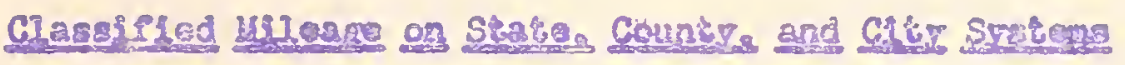

\section{Stato serton}

Interstato Syrtem

2. Earral

2. Urioan

Totel

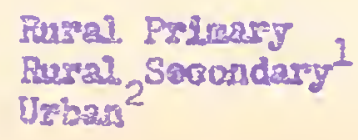

Trtes?
Existing M11enge

785

315

$$
1,100
$$

3,600

5,400

500

Councy Sroters

Primary

Secondaxy

Loas].

$$
\begin{array}{r}
9.750 \\
11,150 \\
55,500 \\
\hline
\end{array}
$$

Totra? $76_{g}: 000$

\section{cast Syator}

Arterial

Reg1dontal SGreots

Total

313200

TOTAL IN INDIALA HICARAY SYSTEA

$98_{2} 200$

1. Mon-FoderaI Aid highnay (130 mis.er) on the Stet/3 Sgrton have

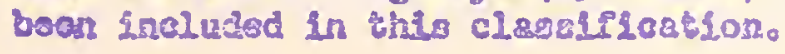

2. Ustha hishoge consiat of poutes through cisles having groates. than 3,500 population end byposses eround thoso elit10z. 


\section{Recommandation}

I. State, connty, and city hightrys should to classified on a furctional besis. Adequato clasalication may require initial clessificatich or reclaseification of highways. The end result, howeyer, showld be an integrated retrors of state, county, and city highways. Desirable mileage limitations chould be sstablished for the highar classiftections and authorization to chango the ciassification of e road is conditions warpant should be bassu or established criteria. 
Chapter IV

\section{SIANDARAS}

\section{How Standards Were Deterninod}

The hifbways of Indiuna have developed througn lmproved concepte of construction, reconatruction, and maintenanco. Trafilc voluwes yohicle size and reight, vehicle speeds, and vohiclo deaign havo also changed and the standards of construction and maintenance have been

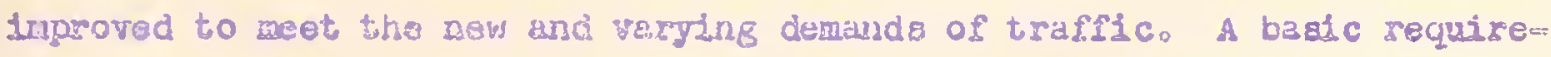
mant for meeting gresent and future damiads for hichways in Indiana is the establishnent of minimum standards of design for tho various clasaes of highways. The me met Include georetric and structural foctures that are economicil ard adequata for present and future traffic denandzo Fundamentally, highway standaras depend upon the level of service that traffic requires. The determination of the level of the standarda to be used requires the development of criteria by which the trafflc domand can be measured. Liginess from whivergities, tho bureau of Public Roads, the American Association of State Highway Ufficialsg Highway Fosearch Bozrd, the National Comaltiee on lisban Transportation, and county and municipal organizations have developed these critarla so that the best: mothods and practices for echioving economy, usefulnesg and Iongevity in highway improvements and mintenance are obtainedo Hasearch and practico in highway defartrents and private industry and the experience of highway onfineors have determined the ctandards that have been used in this study.

Standards for mural roads of various classes are flrmly established on a national basis. Unly recently, however, have urban stindards become of concern. The Hational Comnittee on Urban Transportation, which 

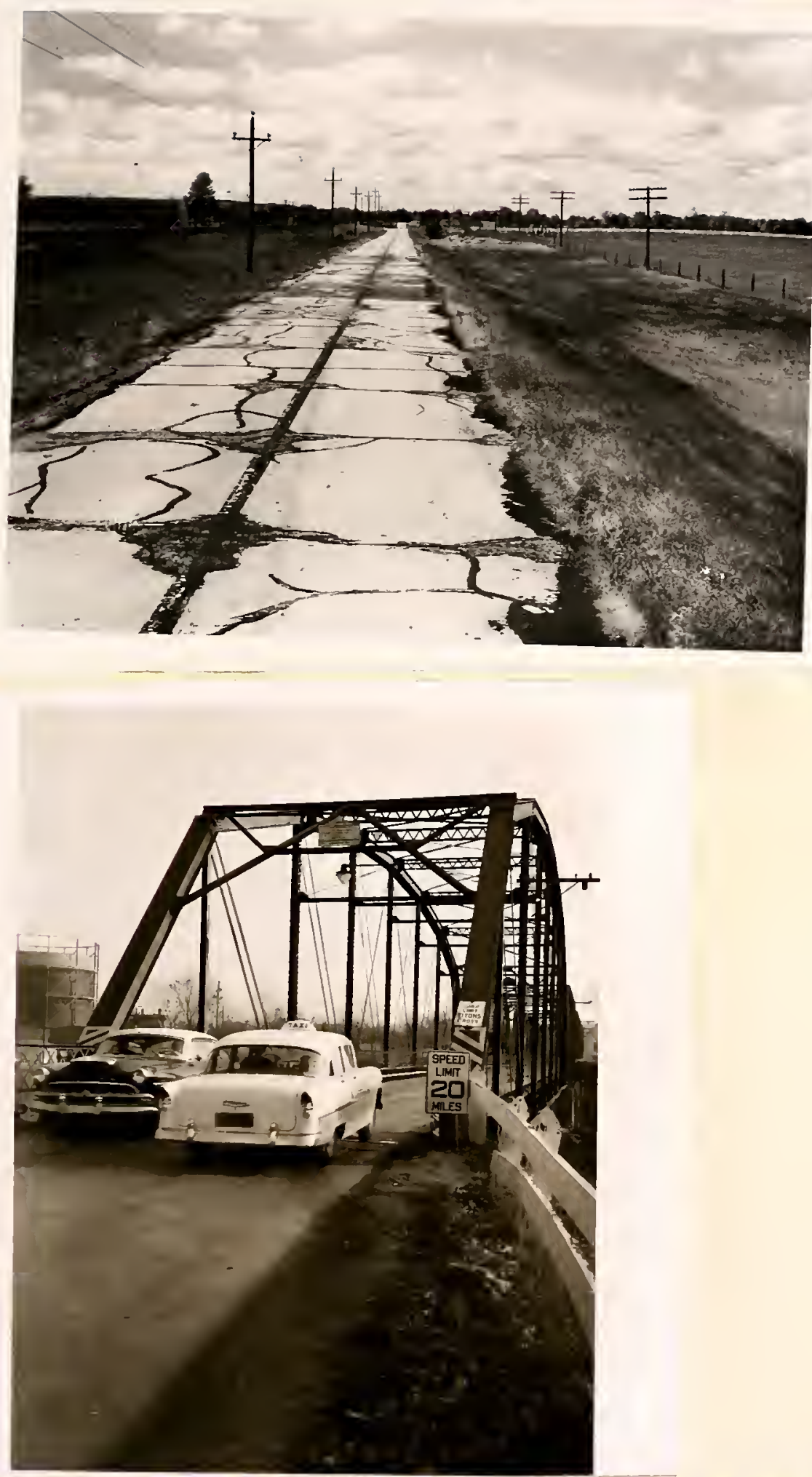

Oxoolete paranents and bridges such as thoso must bo replacod by modera racil1ties meotlng new construction ctandards. 

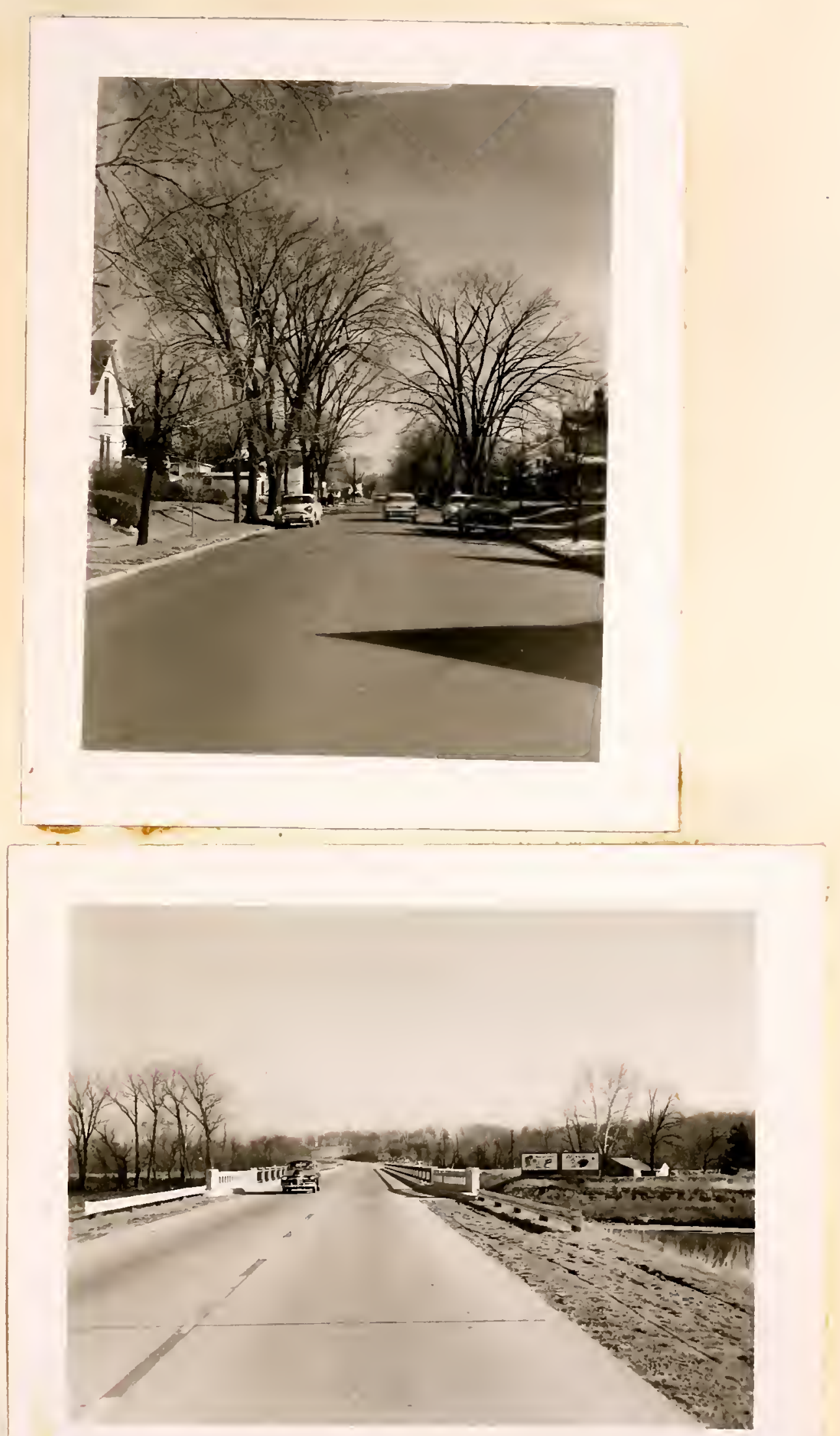

Adequate deglen stardards for streets, highizys, and tridges are a primary necessity if capacj.ty is to be ireredsed and accidents reaiucecio 
was recentify oryarized and is composed of enjineer's in privatog state and national agencies, is developtng urban standardso in the detor mination of standards for design of streets in this study, the host. available information from various engineering agencies was usech

Standerds for a given class of road ray change from year to year. As the demands of traffio changes, so does the quality of standards. Changos in motor vohicle characteristics and oporation, evaliadility of funds, and the supply of raw materials for highwey construction and maintenance have profound influence on highway design atandards.

The State Highway Departmont of Indiana generally rollows nationally recognized standardo for design, constmetion, and maintenance. In some cases, the standards of Indians axceed mininuu national recutrac ments.

Wany of the larjer cities of Indtana have established atandards for construction and design, but there is a leck of uniformity from ons city to another. In soms cities, many arterial streets become obsolete prematurely because they were oujlt to low geometric and structural standarde. Maintenance and rejair costs on these streets are often excessively high and the spparent savings in inftidal con= atruction costs are lost。

Design standards used by the counties of Indiana are not uniform and, In some csser, counties have not been consisteat in theix use when they professed to use them. In fact, gome counties do not have formalized road construction standards. Insdequate bridges, improper wdths of pavement and shoulders, inadequate rijhtwofoway and inadeciuate dralnage are some of the major deflciencies of highways in counties and cities. 


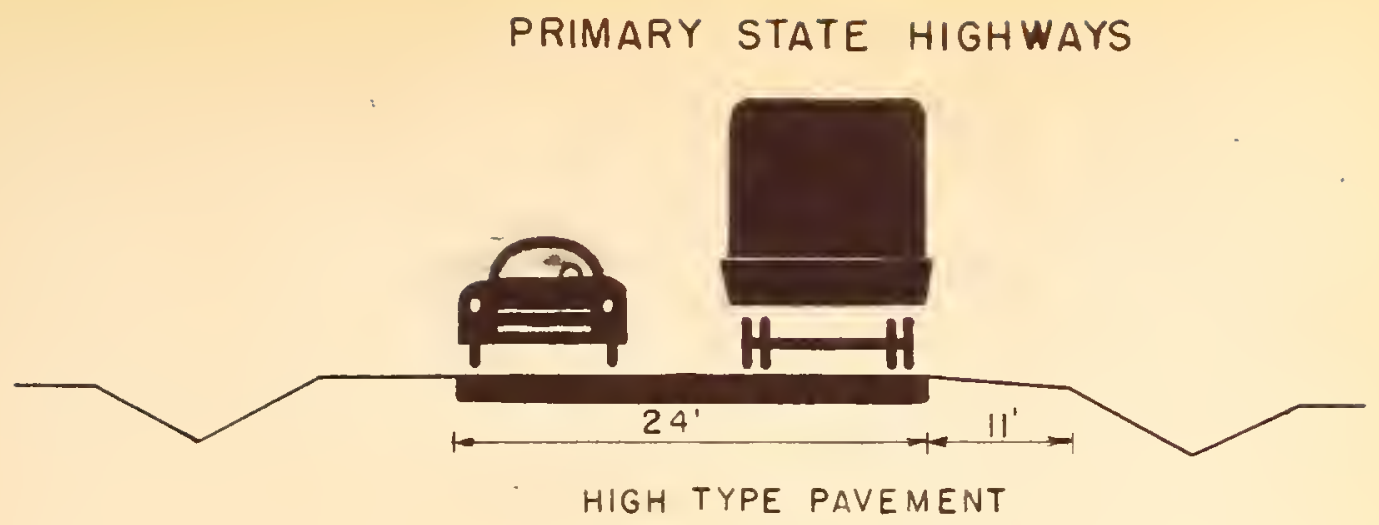

SECONDARY STATE HIGHWAYS

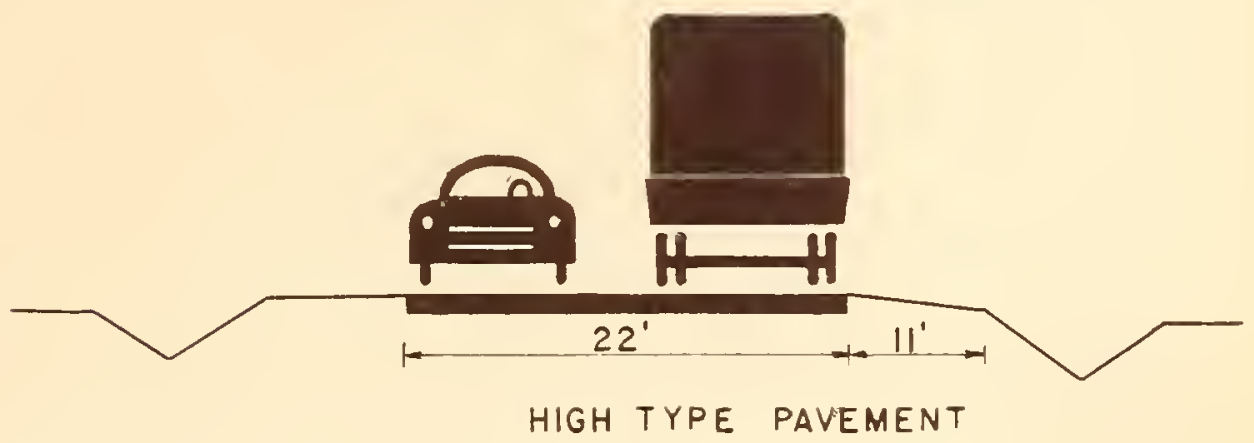

COUNTY PRIMARY ROADS

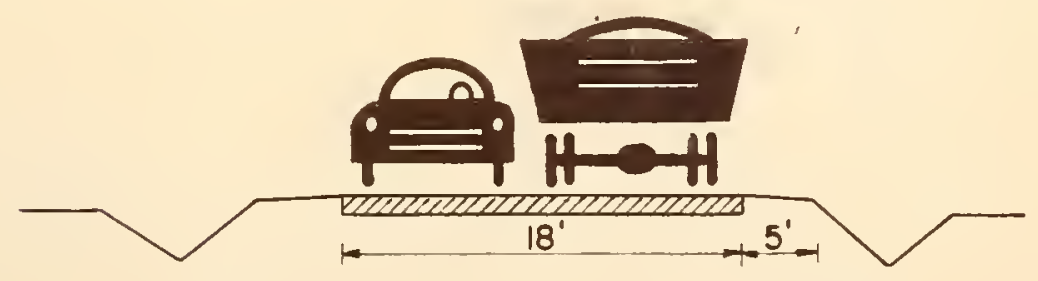

BITUMINOUS SURFACE TREATMENT

STANDARDS FOR NEW CONSTRUCTION

FIGURE 34 

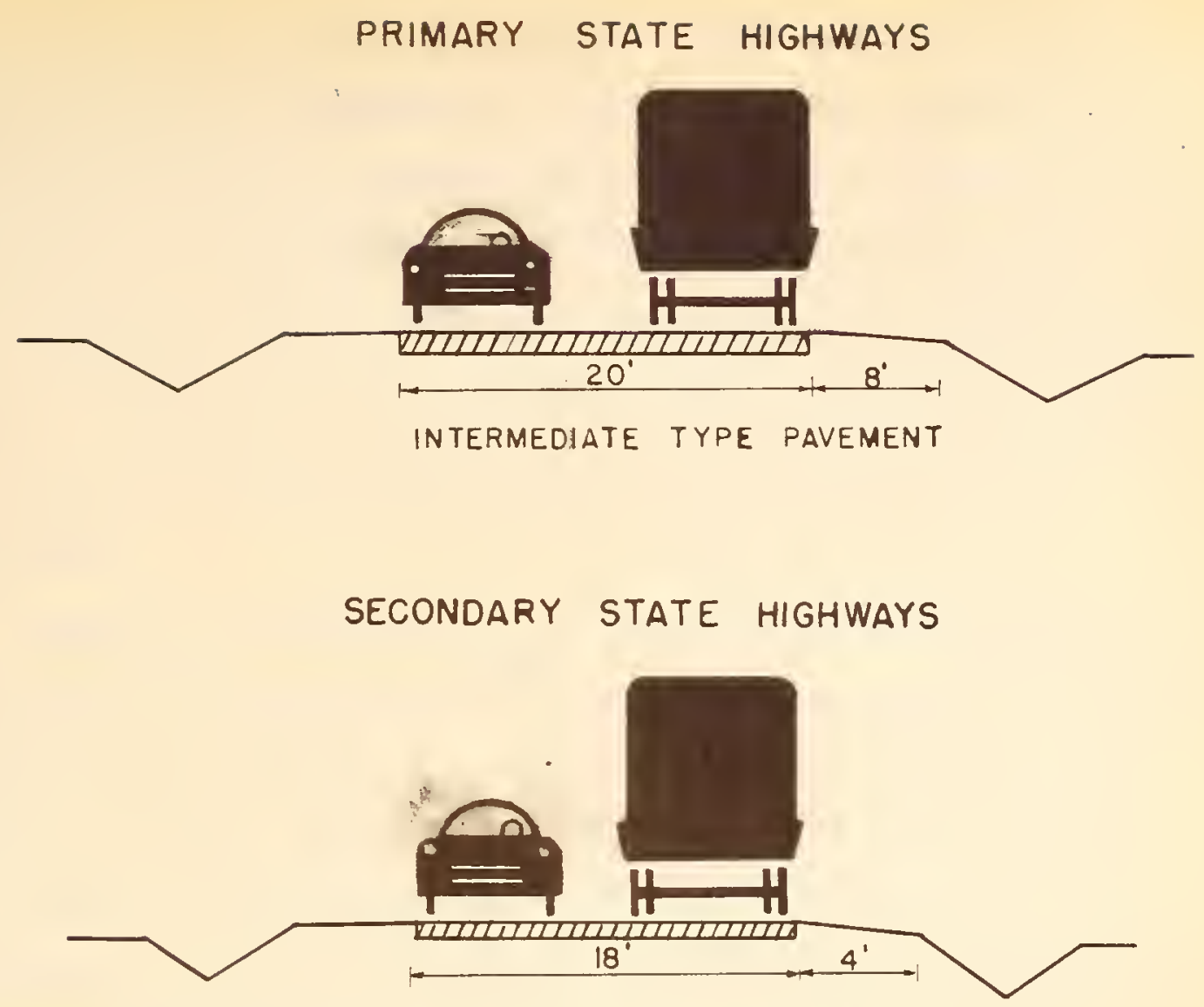

BITUMINOUS SURFACE TREATMENT

COUNTY PRIMARY ROADS

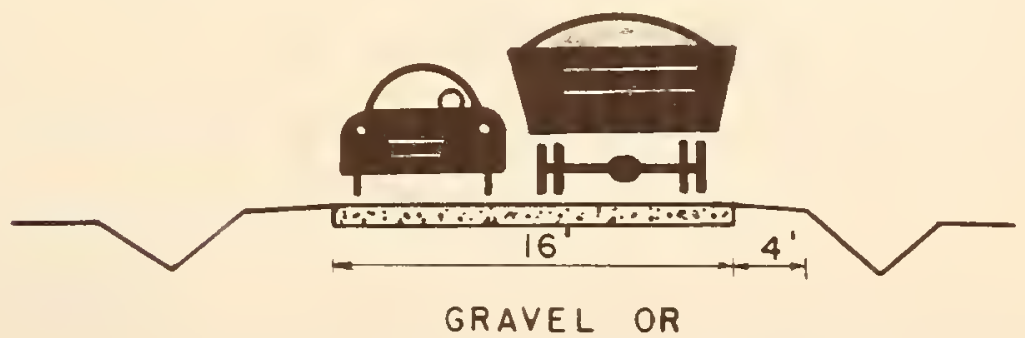

BITUMINOUS SURFACE TREATMENT

TOLERABLE STANDARDS

FIGURE 35 


\section{Study Standards}

Two sets of standards were used in apprateing the need for highway and bridge improvements in Indiana. vne set indicated the geonetric and structural features required for now construction. The second set describes conditions on present roads and streets which were conaldered to met the minimum requirenonts for tolerable traffic service. Any highway which did not meet theee mintrum atandarda was considered intolerable and wos deomed to bo in immediate need of improvemanto

Both sets of standards for the State syatem were developed by the study ataif in cooperstion with the Stato Highway Department of Indiana. Standards for uBo in evaluating county systeme were developed by the staff of the study - and from the iiterature, Giteris to evaluate city streets were developed, although with difflculty because of the Iocal nature of many of the problems involved in such a determination. New Construction Standards

Standarde required for new conetruction conform to the latest highway and Btreet design recominended by the American Astoctation of State Highway Orilcials (60 and 61). It was anticipated tnat construction practices and materlal specifications would be in accordance with mresent metnods. The effect of topography and solls of Indiana was considored in tho determination of etandard and tho total construction costs in the various areas in the atate.

Rural Stato HIghwaya

Tables 55, 51, and 38 ahow some of the sssential features of new construction that were considered for rural state highways。 Control of access, 2-lane versus 4 -lane roads, Erade separations for 
Table 2

Iyptcal Construction Standards

Por

Bural Interstate Highwsys

Element

Dasign Speed

Oporating Speed

Stopping Slight Distance

Maximum Curvature

Maximum Grade

Number of Lanea

Dosign Hour Volume

1975 Average Daily Trafflc

Average Hight-ofoway
Topographr (Flat, Holling, Hilly)

$70 \mathrm{MPH}$

50 to $55 \mathrm{MrH}$

725 Feet

$2^{\circ} 30^{\circ}$

$3 x$

4-lane Divided (6-lane livided)

2500

(3800)

Up to 20,000

$(20,000$ to 30,000$)$

300 Feet 


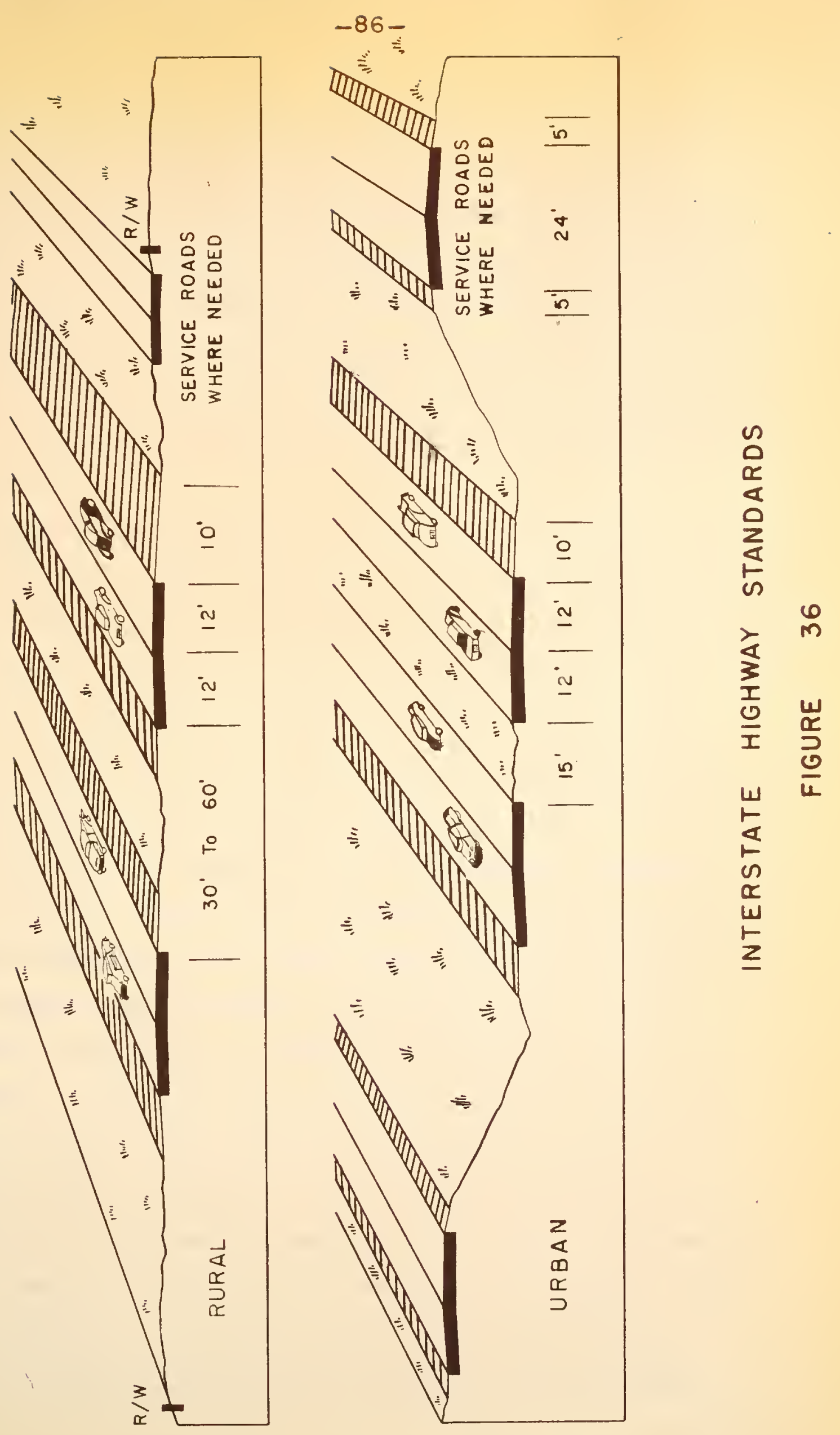


highways and railroads, and other features were considered in addition to the information indicated in the tables. The State System was divided into various classifications - Interstate, Primary, Secondary and Urban o and minimum design standards were established for each class.

New construction standards for the Primary System are quite similar to the standards for the Interstate System. The standards for the State Secondary System are much lower because the importance of these highways from the atandpoint of traffic carried is loss than on the Primary and Interstate highways.

The ability of highways to carry large volumes of traffic is controlled by several factors. The number of traffic lanes, grades, slight distances, percentage of trucks, operating speeds, and roadway clearances are some of the more important elements which affect capacity. All stato highways were investigated in terms of the ability to carry trafflc volumes. Some 2 -lane roade can carry as many as 5,000 vehicles per day, but usually roads carrying this much traffic require 4 -lane divided cone struction. Some 2-Iane highways cannot carry, because of a number of reducing factors, as many as 3,000 vehicles per day. The criteria used in these investigations were developed from information contained in the Highway Capacity Mamual published by the Bureau of fublic Roads (27). One of the major design features on the Interstate System is the requirement for complete control of access. In all cases intersections at grade with side roads and private driveways are not permitted. In this study, control of access on the Primary System has also been antici-. pated, but the control was not considered to be as rigid as the Interstate System. Some grade intersections with side roads were permitted. Prio vate driveway access was limited to present farm houses and private dwellings but additional access was not permitted。 On the Secondary 
Table 3

Tyoical Construction Standards Pural Primary Highwars

Elament

Design Speed

Operating Speed

Stopping Sight Distance

Maximum Curvature

Maximum Grade

Number of Lanes

2975 Aversge Dally Traffic

Minimum Right of Way
Topogrephy (Flat Rolling, Hillr)

$$
\begin{aligned}
& 60=70 \mathrm{MPH} \\
& 40=55 \mathrm{MPH} \\
& 475 \mathrm{Ft} \text {. to } 725 \mathrm{Ft} . \\
& 2030^{\circ}=4^{\circ} \\
& 3 \%=5 \% \\
& 2 \text { or } 4=\text { Lane Divided } \\
& \text { Below 5,000, (2-Lane) } \\
& \text { Above 5,000, (4-Lane Divided) } \\
& 100 \mathrm{Ft}, \quad(2 \text {-Lane); } \\
& 175 \text { Ft. (4-Lane Divided) }
\end{aligned}
$$


System, access to the highway was in goneral considered uncontrolled: however, some accese control will be necessary in those areas where extensive roadside development is antifipated.

While Indiana has a limited access law, full use of the law has not been made, and acceptance of this law by the genersl public has not been complete (2 and 3). The large Investment required to build needed facilities emphasizes the need of protecting the use of now highways by controlling access. Uncontrolled bullding on land adjacent to heavlly trayeled highways results in congestion, delay, and accidents. Ultimately, these roads become nothing but streets with ribbon business development on each side. It is the responsibility of the people of Indiana and highway engineers and administrators to see that control of access is adequately carried out and enforced.

The minimum standards for width of bridges on the state systems vary depending upon the length of the structure. The width for short spans is the roadway width (shoulder to shoulder width) minus 5 feot. For longer spans the width is the pavenent width, plus 6 foet, for the rural systems. All bridges are designed for a load designation of $H 20=$ S16.

County Roads

Because the traffic volumes carried on county highways are substantially lower than the traffic on the state systems, the required standards for new construction on County roads are not as high as for tho state systems. The more important design features for the county are shown in Table 4 .

In this study, these standsrds were used as a genersl guide for 


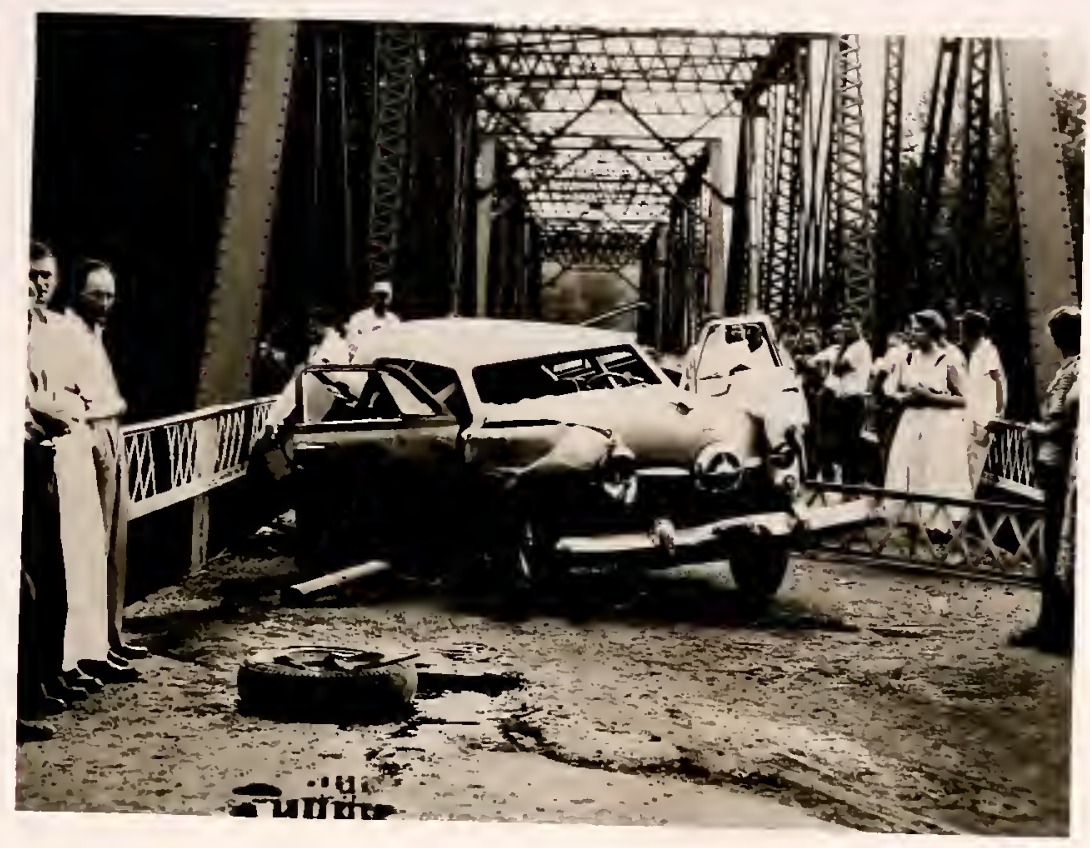

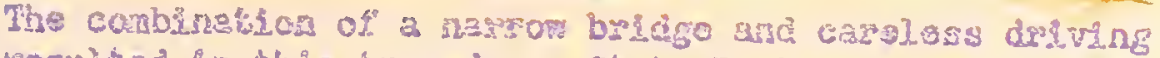

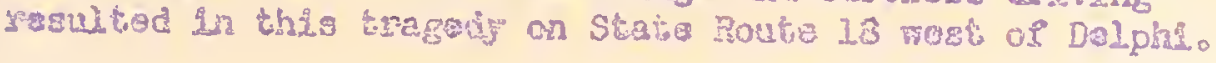

\section{F.}


Table 4

Trofcal Conetruction Standards for Countr MAphwars

\begin{tabular}{|c|c|c|c|c|c|}
\hline \multirow[b]{2}{*}{ Item } & \multicolumn{5}{|c|}{ Eotinated 2975 Average Da11 Traffic Volume } \\
\hline & $0 \rightarrow 50$ & $50-100$ & $100-400$ & $400=1000$ & $1000=0208$ \\
\hline Parenent Type & LОW & Low & $\begin{array}{l}\text { Intors } \\
\text { madiato }\end{array}$ & $\begin{array}{l}\text { Intor } \\
\text { modiato }\end{array}$ & $\begin{array}{l}\text { Inter } \\
\text { mediate }\end{array}$ \\
\hline Pavament Width & 181 & $28^{\circ}$ & $18^{8}$ & 200 & $22^{p}$ \\
\hline - Shoulder WIdth & $4^{8}$ & $4^{\circ}$ & $5^{\circ}$ & 68 & $8^{\circ}$ \\
\hline Horizontal Alignmant & $9^{\circ}-18^{\circ}$ & $9^{\circ}-28^{\circ}$ & $8^{\circ}=16^{\circ}$ & $7 a \rightarrow 4^{\circ}$ & $6^{0}-8^{\circ}$ \\
\hline Crado & $7-208$ & $7-10 \%$ & $5=10 \%$ & $5-9 \%$ & $6-7 \%$ \\
\hline Beldge WIdthe & $24^{\circ}$ & $244^{\circ}$ & $24^{\circ}$ & $28^{\circ}$ & Roedraye $5^{\circ}$ \\
\hline
\end{tabular}


proper construction. Hany other elements which are not indicated in Table 4 were considered in deternining the types of construction re quired. Only linited constmetion should be done on roads carrying less than 50 vehicles per day because most of these highways can be kept in adequate condition by proper maintenance. County roads often have adequate surfaces because road materials are readily available in Indiana but have serious deflciencles in pavement width, drainage, and alignnent. Design atandards for county roads caxrying more than 1,000 vehicles per day are similar to the minimum etandards for secondary state highways.

\section{City Strets}

Kinfmum requirements for newly constructed streets should not be less than an intermedlate type pavement with curb and gutter and proper drainage and this construction should be the responsibility of the land developer.

Many factors in a city's development have an influence on street widths. Among them are requirements for parking, existing right $=0$ m way widths, and the location of Industry, shopping, and residential aress. The cost of urban construction is especially difficult to determine because existing right-of =way widths, sidewalks, and driveways influence these costs. In this study where right=of way was restricted, improve ment was in general confined to the use of the present right -of oway. Problems of this nature are camon on overloaded city arterial atreets. Large cities in particular, have many miles of arterial streets which are now carrying traffic to the limit of their capacity. In mast cases other parallel streets in the city must be developed to carry these overloads and ease the congestion problem. 


\section{Tolerable Standards}

Tolerable standardo for the state systems were developed by englneers from the Jolnt Highway Feeearch Project and the State Higho way Department of Indiana. These standards were liberally applied to gections of highway and in many cases were only used as guides to good judgment.

Facts used with respect to highway conditions in capacity comput = ations for highways with tolerable conditions were different than those used to calculate capscities for roado built to minimum design atands ards. In general, lower operating speeds, steeper grades, more curving horizontal alignment, and less commercial traffic exist and the present capacity was deterained for these conditions.

Considerable atudy was necessary to develop tolerable standards for county highways. Each county has special problems of finance, topa graphy, and available materjals which affect demands of traffic service。 Table 5 shows some of the mure important criteria that were developed to determine tolerable roadis and bridges on the County Primary, Secondary, and Local Systems.

A minimum traffic volume of 200 vehicles per day was required for a bituminous surface. In general, all county roads on the Local System were considered tolerable if surfaced with a material which permits adequate service during all seasons of the year. $A$ fow local roads were consldered tolerable elthough they did not have all-weather surfaces。

County bridges were required to be in fair condition and at least 18 feet in width on the Primary and Secondary Systems. Safe load designation H-10 was required. 
Table 5

2018able Standarde

IOF

Countri Hisherse

Item

Surface Typa

Surdoue Widish

Shouldar Wldis

Mordzontal Allgragent

Gradisnto

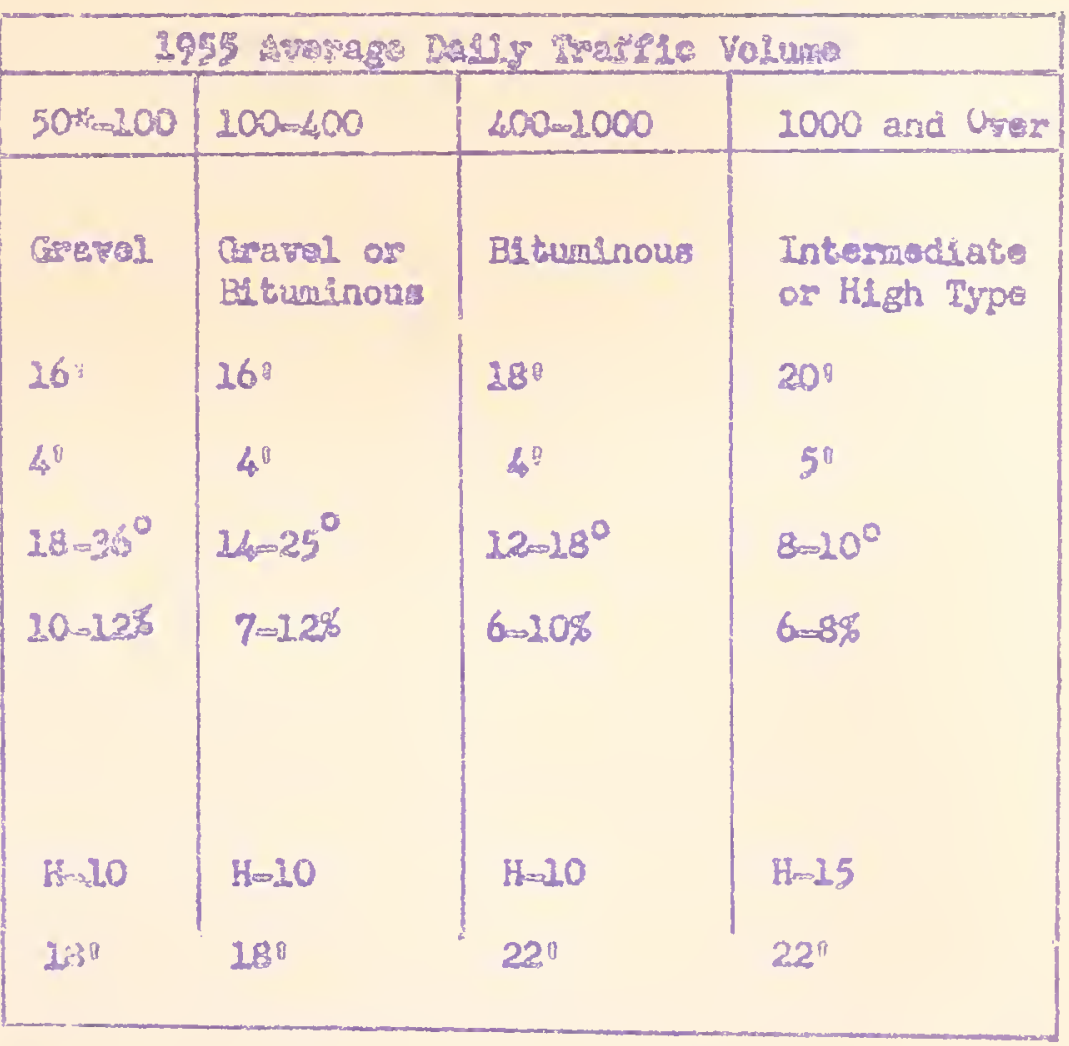

* Tolerabla standardo mere rot dereloped for roads carrying 208 a than 50 Fahlclor por deg becauss they aro not kpplicsblo. 
In this study the axtarial streta of cities were requiteo to carry traffec without axceeding practical capacity. If additional cepacity could be obtained by the remoral of parking or by the use of effective trafic operational procedures, these reasuras were uthured before reconstruction or widening the etreot was nscsssay. Tho payeo ment was required to be in adequats struciural condition with curba and guttore, sidewallis where needed, and proper gtom eewer dratizge. Formal tolerable standards, other than general conditione outinsd. were not determined because th was not possible to define gasudarda that would apply to each cityo

Because tolesable standaras fos resicential st3eets are a matter of local concern, these standards were also not fomally developoe.

The requirements for these strects were computed by a process of esto nation of overall needs on the total residential giveet mileage of tho sterte.

\section{Stzes ard hes ght}

Highwy design standards have changed becauge vehícles of evers increasing waight and size use the road The most noticesole end ino portant changes have been causad by hoavy, truck-trailer comblnations traveling upon the state systens. Prior to iforld was II there were 5 axles per 1,000 trucks exceeding 18,000 pounds traveling the highrat In Indiana but by 1955 this number had increased to 54 per 1,000 \& tencfold increase in $\psi_{4}$ years. The total number of repetitions of these heavy loads has also increased because of the increased uss of the hervy truck $(20,46)$.

The maximum alowable single axle load of 18,000 pornds in Indiana 


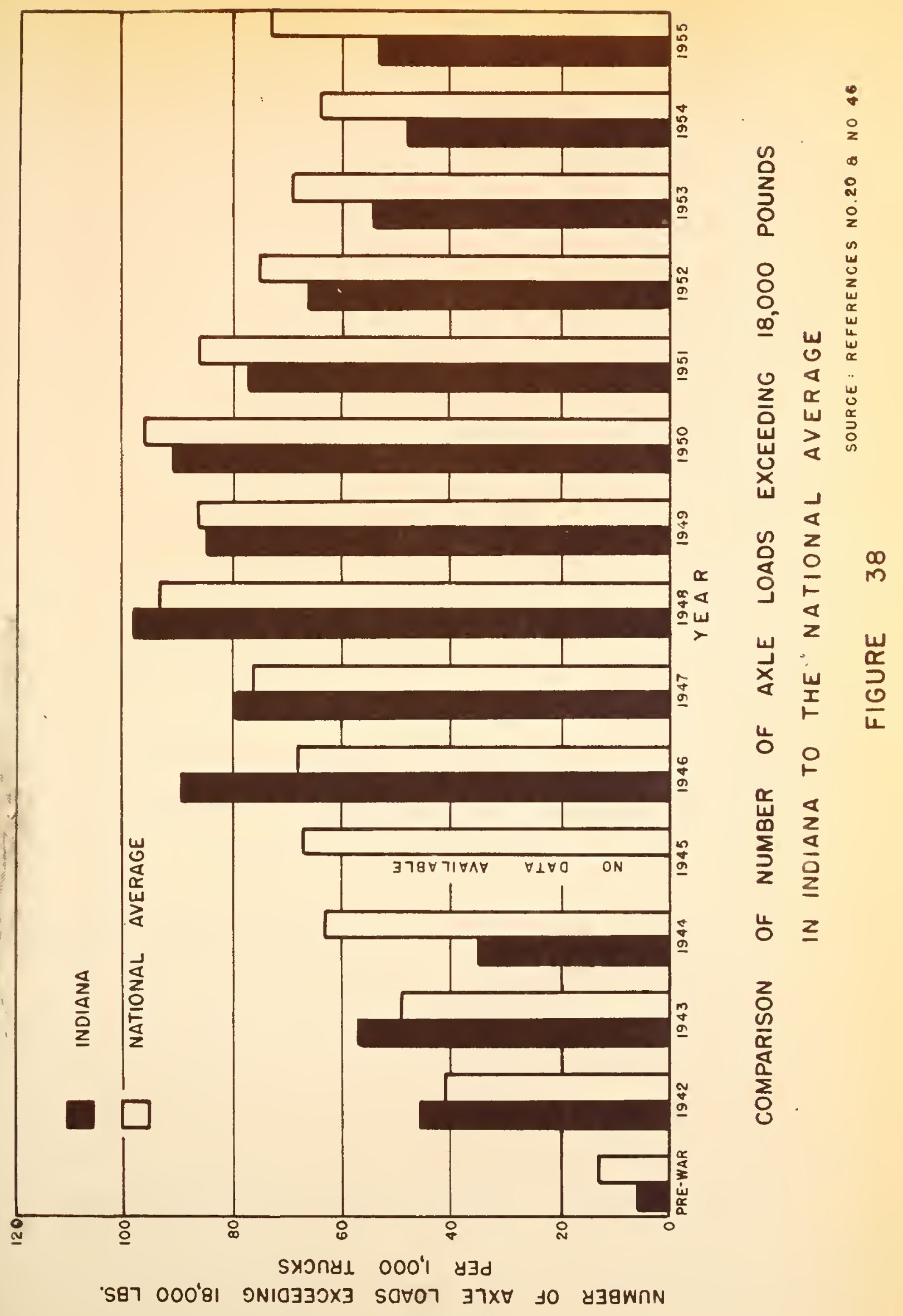


conforms to natioxal stindards as recommenced by the American Association of State Highway officials. Indiana law permits certain highways to be designatied as heavy duty highways whore the legal axle limit is 22,400 pourids. Ianden axjo loads are limited to 32,000 pounds per axle, except on designated heavy chuty highways where 36,000 pounds is the maximum legal load $(69)$.

The naxlmum legal gross load in Indiana is 72,000 pounds which approximates the raximur $20 a d$ recomended by the AASHU (69). Horever", total gross load s.s not directiy related to axle spacings or total length of truck unit. The AASHU ctandard reduces allowable fross loads depending upon the length of wheel bass. Tisis requifroment prevents hesvy concentration of 10ads within a ghort distance. More recenty contructed bridges and roads in Indferre cen support the increaced losis that have occurred in the past fek years; however, many of earljer origin are not capable of beaxing such weights. Cortain heavy duty highways may adequately support a 22,400 pound axle load without causing structural damage bit data are not avajlable to substantiate this pointo Performarce under evermincreasing heary truck traffic will give an answer to this question.

Regulation of Stre and ilsight

Because pavemonts and bridges are designed under specifle stando ards, it is necessary that the revisions in these standards be carefully controlled to prevent indiecriminant changes which vould result in premature functional and structural obsolescence of pavoments and bridges already constmeted. This is one reason why weight and size limititions on a vehicle must be kept reasonably constant, and that increases be 
mage only after carejul considexations of the econoric factors involvedo Table ó gives a comparison of the logal vehicle lintations in Indian with those recomnended by the Anertcan Bsgociation of State Haghwy ofiscials.

\section{Recormendations}

The design and characteristics of the vehiche changes quite rapidy; however, highways cannot, be econonicaliy changed as readily as the vehicle. If ghways, thorerore, mst be constructed to minimum stancards which anticipate iture demands of traffic. By this method the most eficicnt and economical use of the highway plant can be acm complishodo standards of constmetion, howover, need periodic revevt and possible revistor to keep pace with changing denands and needs of trafific。

It Is necessary that the state, county, and city jurisdictione cooperate In the development and adoption of mintman standards for the conetruction of their highways and streets. These standards should be based on the best ongineering prectice with a considaration of econonics and to compatible with the traific and safety requirement of each high-

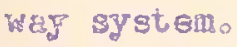

It 1 s recommonded that the present limited access law be wisely used to protect the major state highways from the strangulation of un= controlled roedside development. In order to insure the safe and economical movement of large volumes of traffic, limited access controls mat be applied vigorously whate they are apolicable. 
2able 6

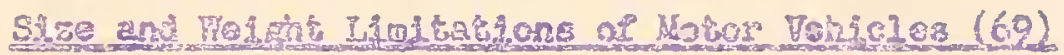

\begin{tabular}{|c|c|c|}
\hline $\cos x$ & Indiana) & Reccormended br A, $A_{0} S_{2} H_{2} C_{2}$ \\
\hline Whdth (Inches) & 96 & 96 \\
\hline HลI ght ( & 13.5 & 12.5 \\
\hline 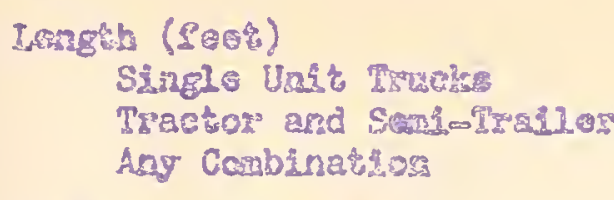 & $\begin{array}{l}35 \% \\
50 \\
50\end{array}$ & $\begin{array}{l}35 \\
50 \\
60\end{array}$ \\
\hline 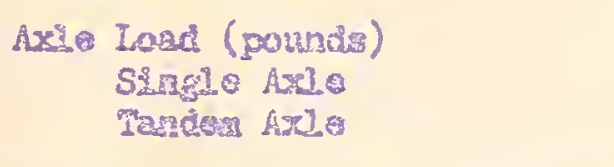 & $\begin{array}{l}18,000 \\
32_{3} 000\end{array}$ & $\begin{array}{l}1.8,000 \\
32,000\end{array}$ \\
\hline 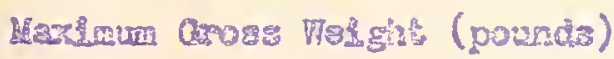 & $72_{8} 000$ & $71_{3} 900$ \\
\hline
\end{tabular}

* Bras allowed 49 zeat

* On arsfgnated hoaซy duty highzage 22,400 lbs.

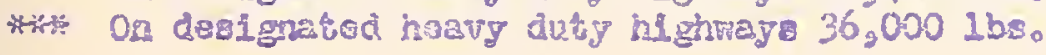



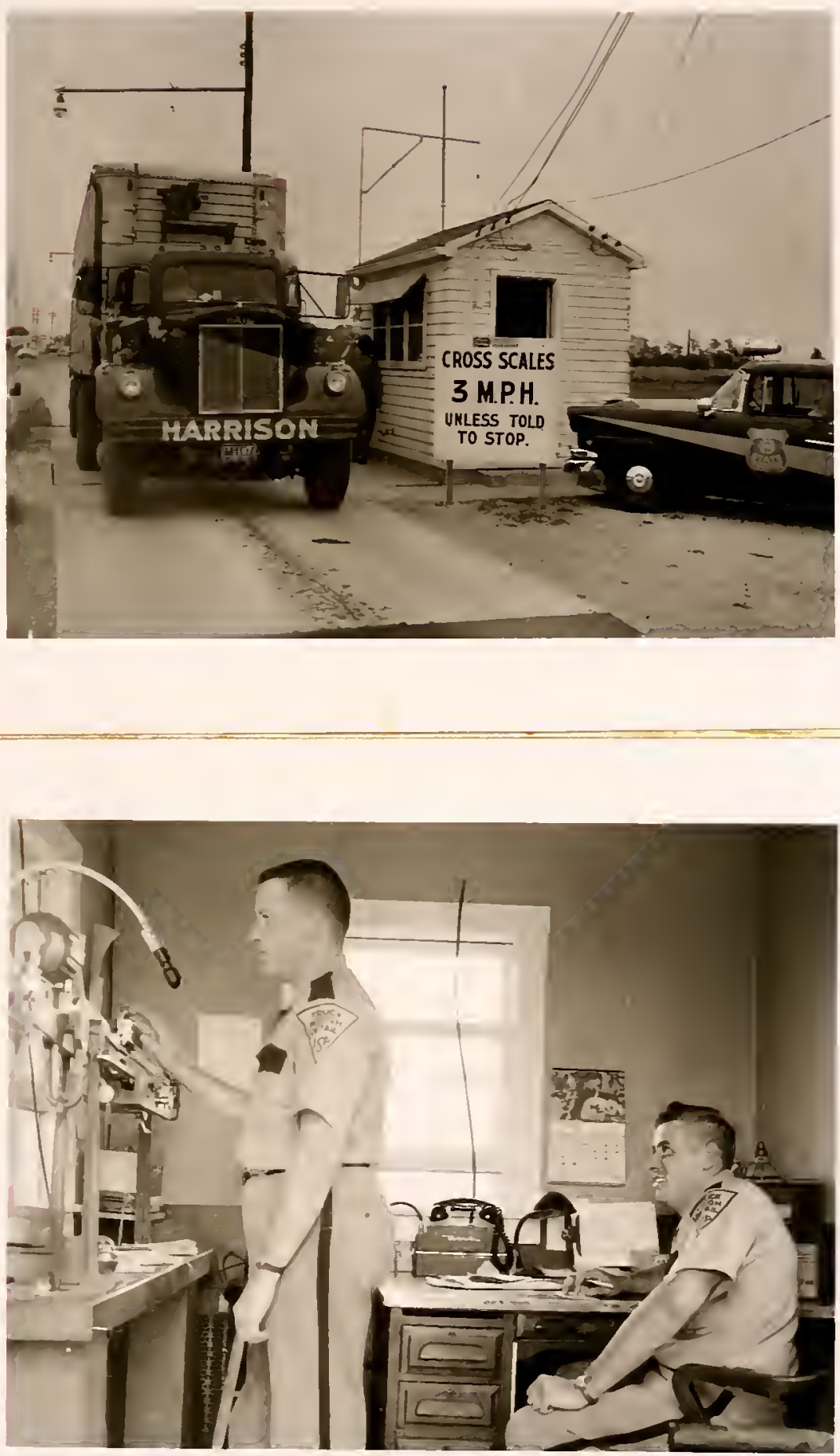

The control of 8120 and welght of rehlcles 10 ossentlal to protect the oros-incressing highay investront. One method of control it the roadsido meighing otation 
Chapter y

HITHUA.I UIMETRITUIS

Geners: Eackground

The field of highway traffic operatons is a relatively new branch of highway engineering. Not rany yeara ago tre motto of the cay was, "Get the highway out of the und." This concept has been changed by appreciable achievoment of that goal and the rapid growth of traffic in recent years. The motio today is "Get the highwey out of the mulde."

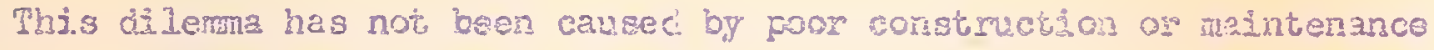
oractices, but by increased volunes of traffic o traffic which has out w grown old ard established street and road systems and results in conges tion and delay to yehicles and in numerous accidents.

In order to afficientiy utilize the olcer highway and to obtain maximum benefito from the now facilitis: the art and science of trafic engineering can be used to groat advantage. Bi inonasing the epfectiver

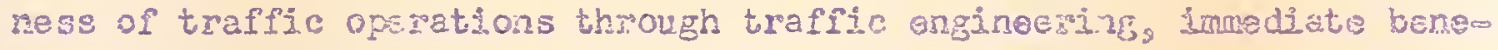
Ifto in improved efficiency and safety of traffic can be obtained。

The motorf st in traveling over rural highays expets to nove at a reasonatle speed and with confidence that oarking and gigning wil give him guidance to his dastinetion. In urban sreas the motozist ranto to drive without unnecessazy delay caused by inefficient morement of vehieles, He 2180 wants to find \& conpenient place to park within a reasonable distance of his point of destination and desires clear, concise signs to gujde him through urban areas to provide safe axrival at his desinination.

\section{State HIghway Sreter}

Kesponsibility for traffic opsrations on the maral and urban state systems is primarijy vested in the Trafic Bureau under the Construction 

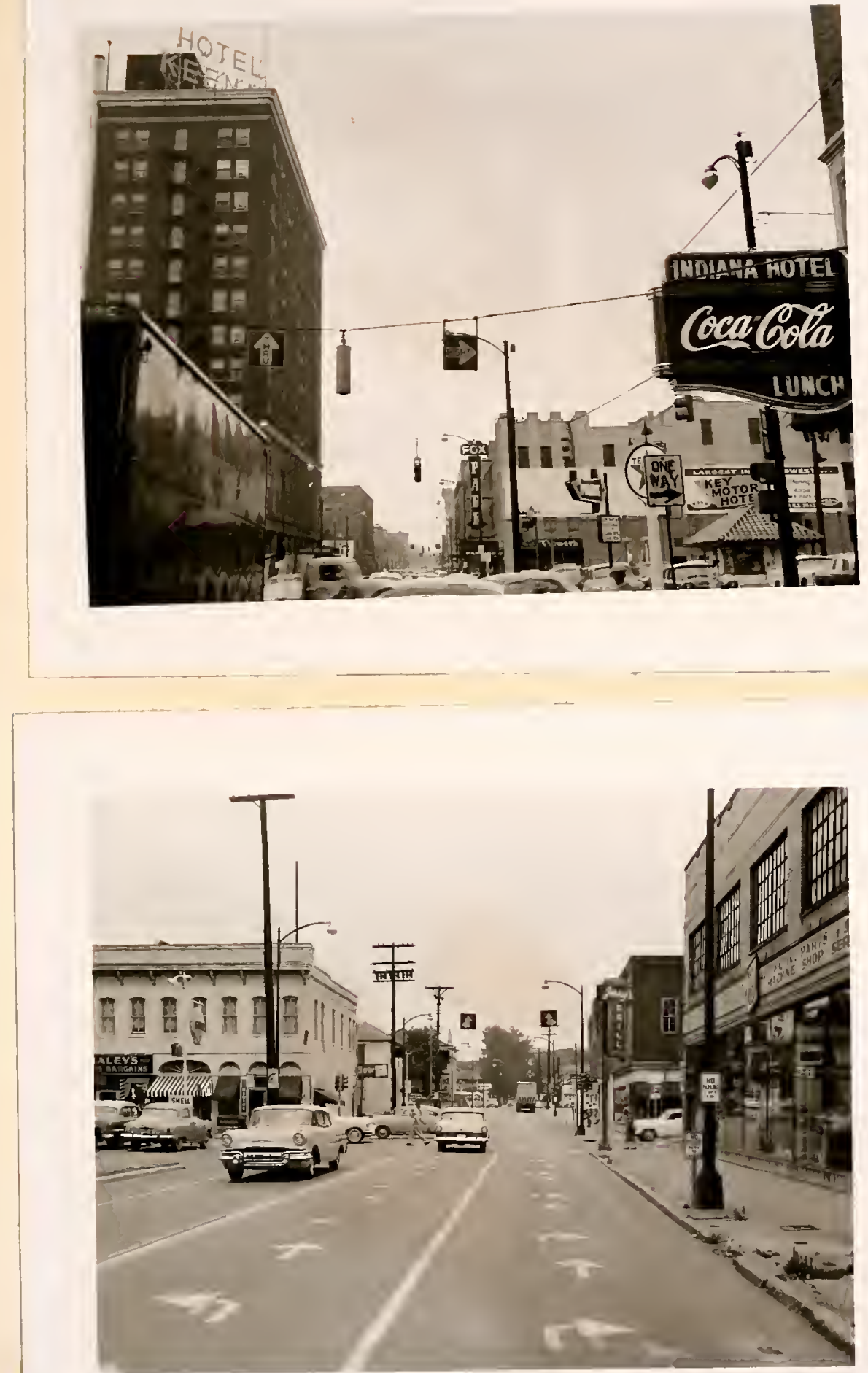

Overhead signs, which can be seen from a distance, are effective aids to drivers who are not familiar with a cityo 
and Maintenance Divisions o: whe State Highay Departmento The listrow politan Area Trafic Survey and the Highway Planning Survey Soctions also perform some traffe encinsering functions, madnly in the areag of data collection and traffic planning. Informal working relationships and cooperstion between thess sactions are maintalned.

\section{Deficlencles in Trasie Conigol}

In general, standards for tiaffic control devices in Indina are comparable to national standards and to practices in other stabes (47)。 However, there is need for correcting many deficiencies in the application of thase trafijc control derices. Location of signs can be improved, especialy thoge portaining to zoute markinge and drections of trevel. In many cases old signs do not conform to national standards and should be replaced as rapidly as posaible. More extensive use of reflectoriaed and overhead directional signs and of larger and legible signs should a.so be investigated.

Traffic signal tinjug on state highways is often not coordinated whth other traffic signels in nany cities. fis a result signals are operating independently of one anothes and promote undue congestion and delayo

\section{Model Traffic Organization}

- Because of the heavy volume of traffic carried by the state systems, it is essential that tiaffic operation functions be organized go that maximum efeiciency of operation can be accompliahedo It $1 \mathrm{~s}_{8}$ therefore, desirabie to integrate ossential traffic anginering funco tions to permit operationg and planning to be perforked most efficienty 


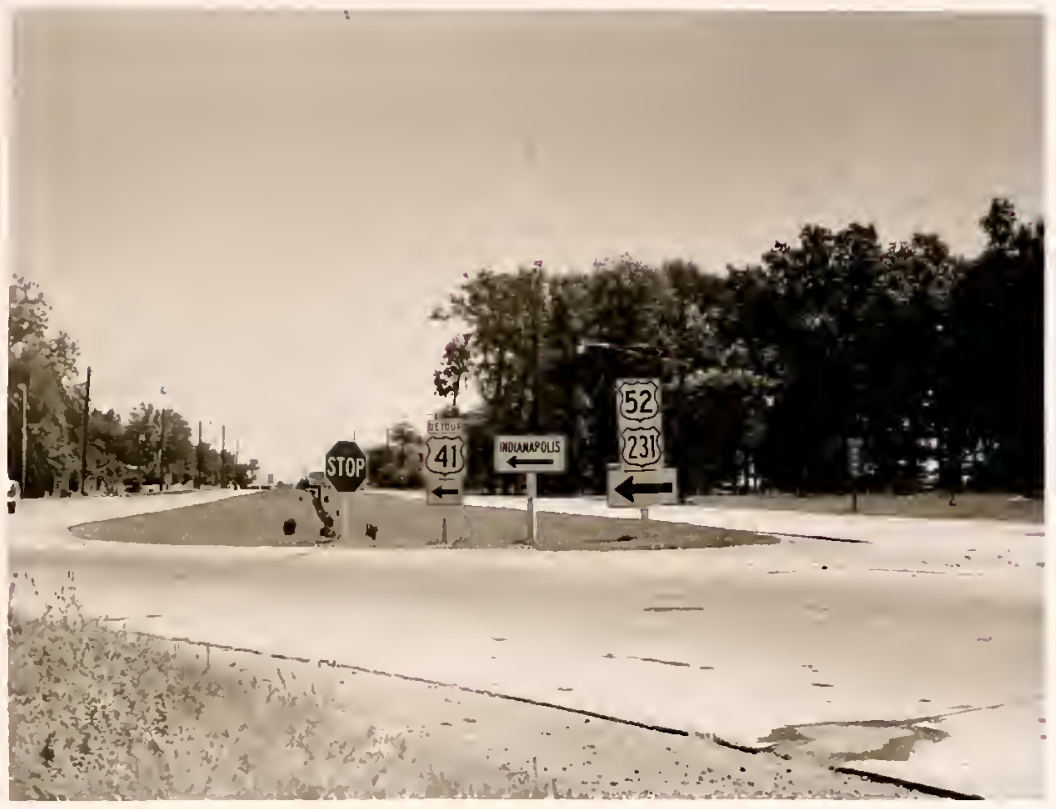

When outs=or =forn drivers are bethldered by a maze of route markers and sł.gns such ag these, hazards are increased and treafi: movenent becomes diso organized. 
The following functions are isential:

I. Traffic Operations Functionz。

E. Insuance of Ievions to Stata Hamel on Unifom Treffic Contral Devices.

b. Supertision of snstaliation and maintenance of treffic control deviceso

c. Spesd zoning and pesing control along state highways.

d. Aezident anelyess end study of hich-zcoldent locations.

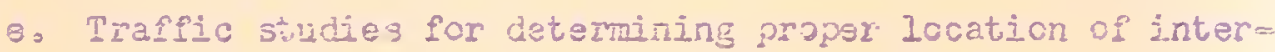
section contrils, and other conticol cevices.

f. Sizay of urbar sections of state highrsyg anc treficic problens on relatad citj street3.

8. Ald and advice on traffic probleras to cities and counties wich do not have traffic enginesra.

h. Redesizm of incersoctions, including channelization and illurination.

2. Trafic PlanzinE Functions.

2. Periodic collection of data on higrtays and bridges, treffic volures, speeds, and truck reightso

b. assembly of traffic data for proposed projects, with predictions for the future.

c. Zconcmic îeastbility studieo of alternates, and related siluies for rcute selectians.

d. Perlodic analyses of highwey needs, gufficiency rating and programing stujles。

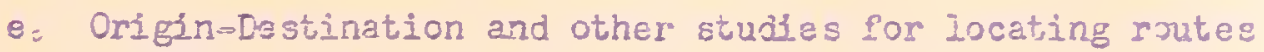
in metropolitan areas.

fo cher studies included in the scope of the stateridid highvay planning survey.

3. Trafflc DeEign Tunctionso

3. Review and 2dvise on design etandards from standpaint of traffic service.

b. Keview prellminary geometric design features of proposed projects, in cooporation with the design enfireel.3. 
So Revlew prolimi ary hảghway plans and advise cn signal design and other control devices for new projectso

cio Review partitis and plans fer Foadeide entrunces.

Stardards of porformance for the above functions should be estebIshed by The State Highney Departmento The engineer in charge of treffic In eech highwey district should recaive guidance fron a central ojfice. It rould be his rosponstbility, horever, to see that the treffic and claming oparationa in his district agree vith the standards detemined ty headquarterso

\section{Fycure Requirements}

To derelop a propar program of effective traffic operation and planning, it is necessazy to increase ongineering personnel in this area over tiose presently avaliable. Not only are additional personnel requised to carry the spiraling load of operationel functions, but albo adbiticnal personnel are jequired for a greatly needed end expanded aetivity in effective planning.

\section{StaterGity ReIationshios}

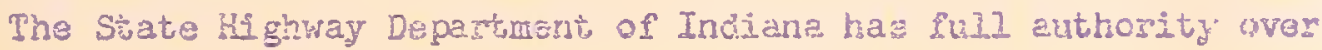
traffic controi devices on urban extensions of the state Highway system. As a result, cities have not indigerdminately installed traffie si.gnals as ofter heppens their anch controj. Is divided between city and state autholities. The state also has control over speed zenes establinhed through varlous imanctpalities on highways on the Urban state Syatera

In some cities, the state routes ranbie through the city over circut.tous zoutes which pess through congested business distro.ct.s. Relocation of thess routes to provide disect travel and byapass the 


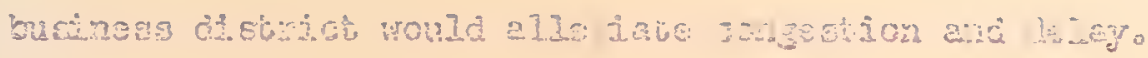

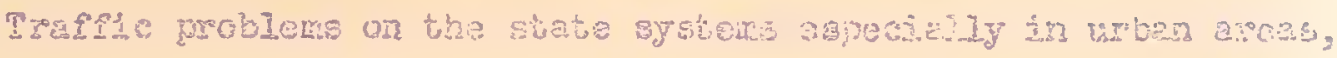

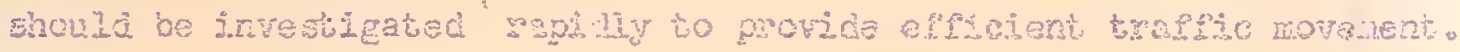

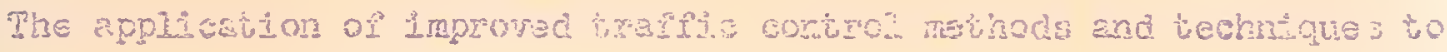

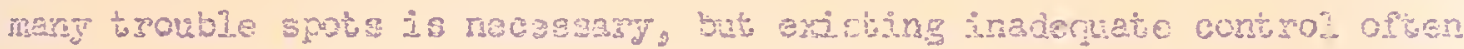
semains until the sibuation becones Intolezajo. Ingroved cooperation

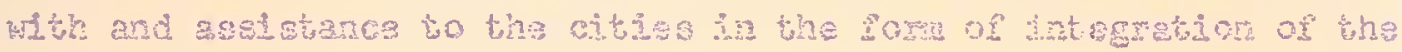

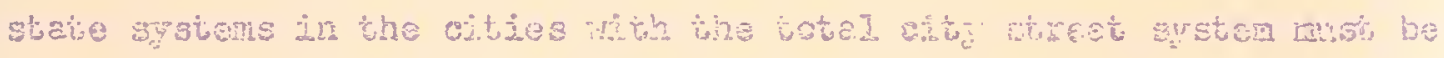

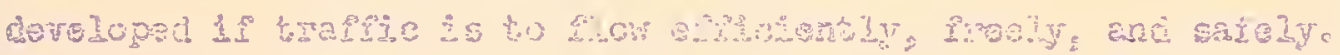

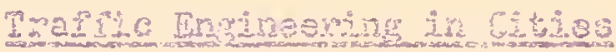

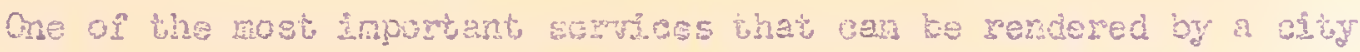

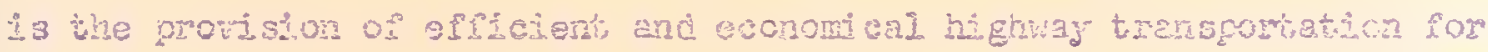

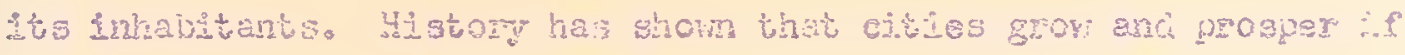

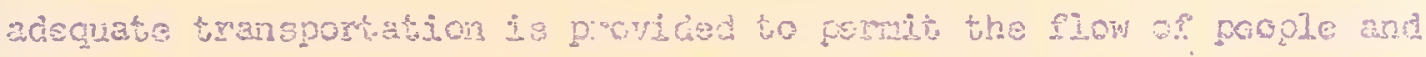

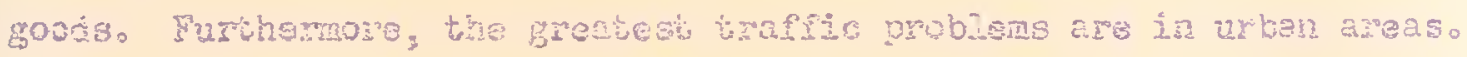
Thareiore, tref̂ic plaming snd oporation of the street syaten or a

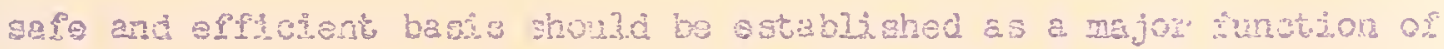
good cht govermingto

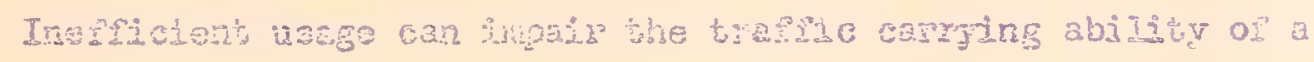

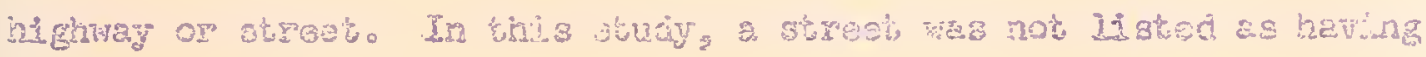

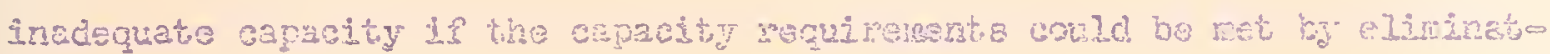

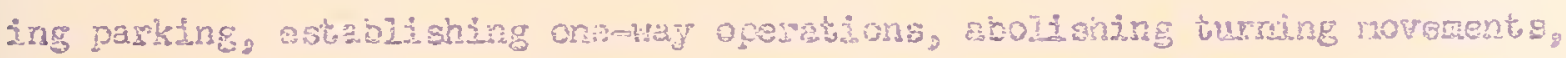

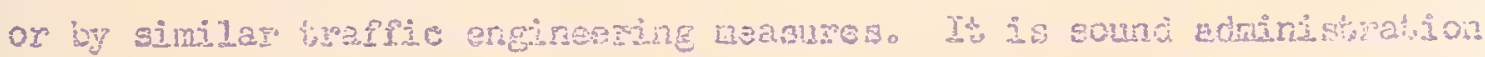

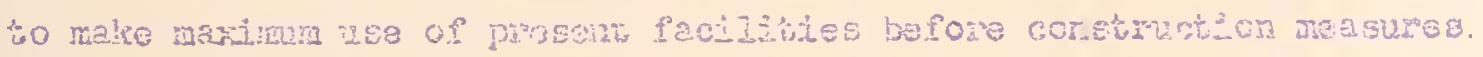
Exs corsidered.

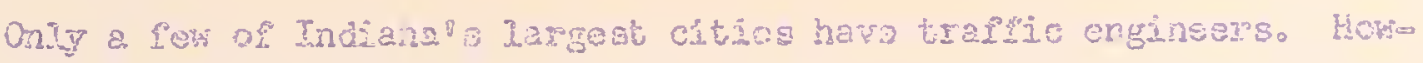

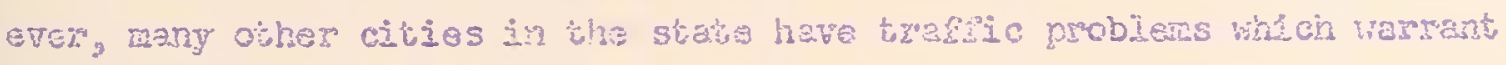


the full-time services of a traffic engineer. Many smaller cities do not need the services of a full-tine englneer, but could use ore on \& part-time basis. It is estimated that there should be the equivalent of at least two full-tine traffic engineers for each 100,000 people in a city. This estimate of the proper number of engineers indicates that many more professionally trained personnel are needed in the cities of Indiane.

The trafilc engineering divizion in a city should be pleced in an enginsering department or organized as a separate department of city government. In many cities, traffic enginsering duties are the ress ponsibility of a traffle offlcer who is usually a member of the local police force. In most of the mall cities such an arrangement rnay be adequat, but the asaigtance of state traffic engineering departments or other compotent iraffic engineering consultants should be obtained for the solution of mang problems.

More effective application of fundametal traffic engineering principles and practices is urgently needed in Indiana citieso work beyond maintaining and opexating traffic control devices is needed. Some of the necessary traffic englneering functions of an effective traffic enginsering department of a city are as follows:

1. Conduct traffic surveys and engineering investigations of traffic conditions and make recomondations for improversents or changes in present streets.

2. Conduct longorange studies to deteruine overalI transportation needs of the city.

3. Detormine the type and location of traffie control devices, including the maintenance of slgns, gignals, pavement markings, 
and other necessary controls.

4. Establish traffic mlas and regulations subject to the approval of the city council. Included are parking regulations, turno Ing controls, oneoway streets, arterial streets, traffic sige nal timing, pavement markings, loading mones, and other operao tional procadures necessary for safe and efflclent travel. Transit routes and unloading and leading zones should also be subject to the traific enginaer's euthority, especially as they affoct the solection of ore-way streets.

5. Determine present and future neads for offostreat parking facilities and reviow and approve such plans for design and location.

6. Review of othar miscellaneous activities which would affect traffic operations such as driveways, parking lots, subdiviaion layout, and shopping center location.

\section{Treffic Engineering in Counties}

Although the counity highway systeins do not carry the heavy cono centration of traffic that is found on the state and c1ty systems, many operational procedures can be adopted which will exvedite the movement of traffic and provide for afer and more efficient travel. Une of tho primary needs of the counties is a uniform roed marking and identifio cation system. At present only a few counties in the state have estabIlshed such an identification system.

Adequate marking of nospassing zones and centerline locations on the paved County Primary and Secondary Systoms is badly neededo Signing Is usually not adequate and oftan does not conform to accepted standardso 


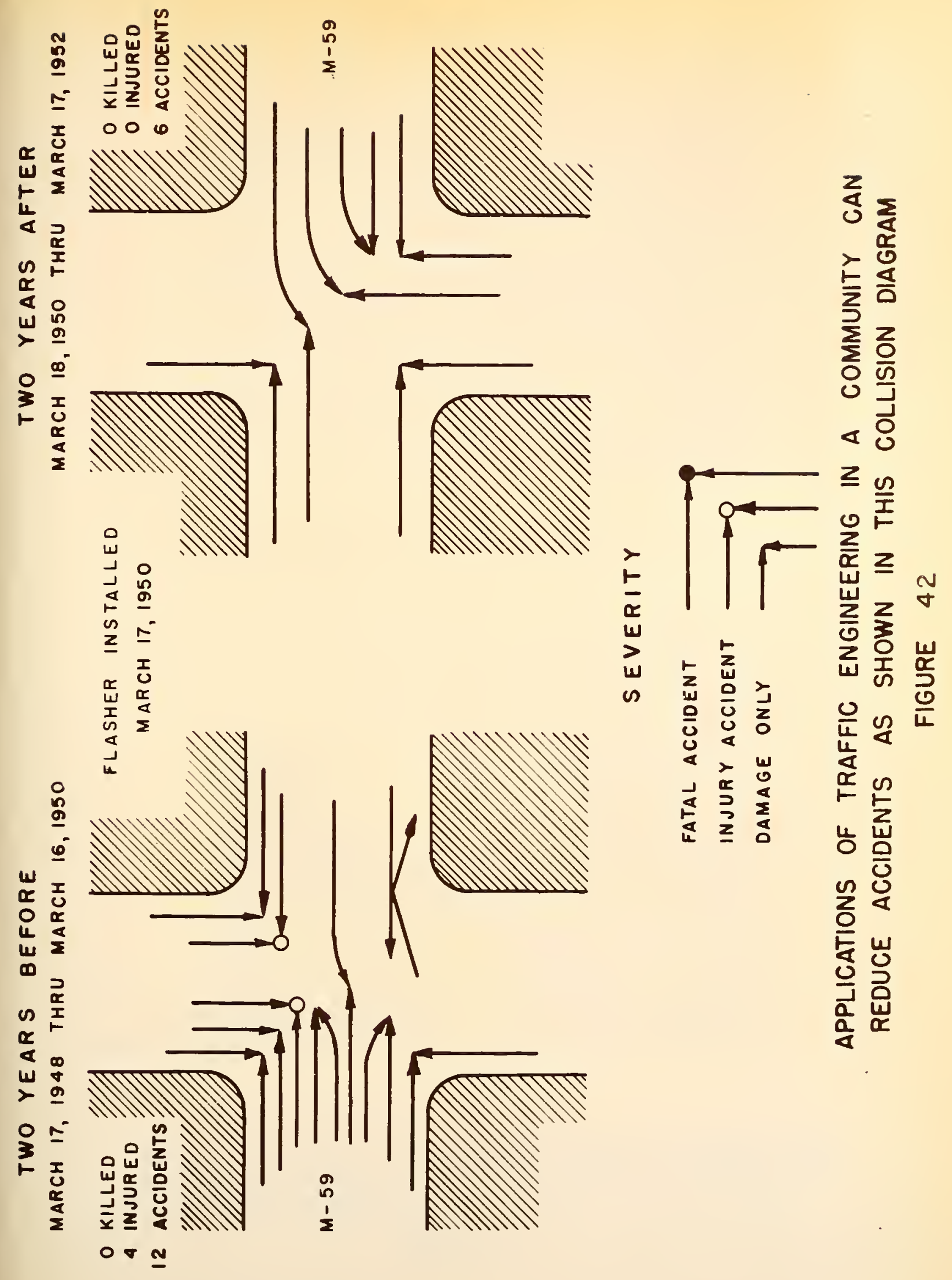



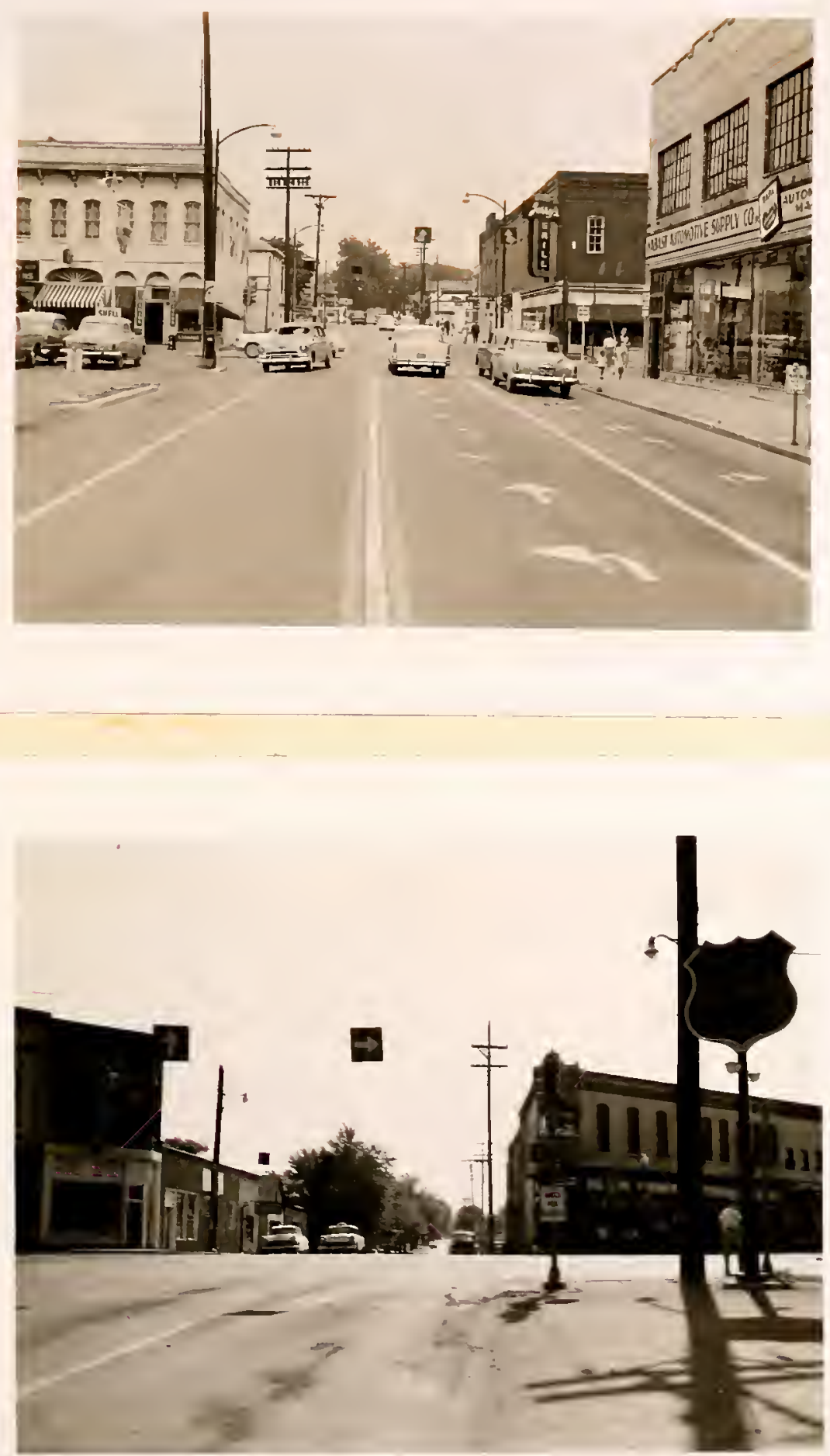

Relat1valy Lncrpchito inptovmonts, auch as properly losated

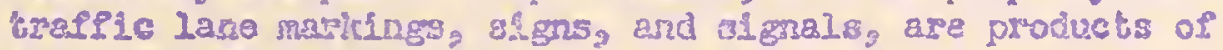
acund Traflic Engincoxing 


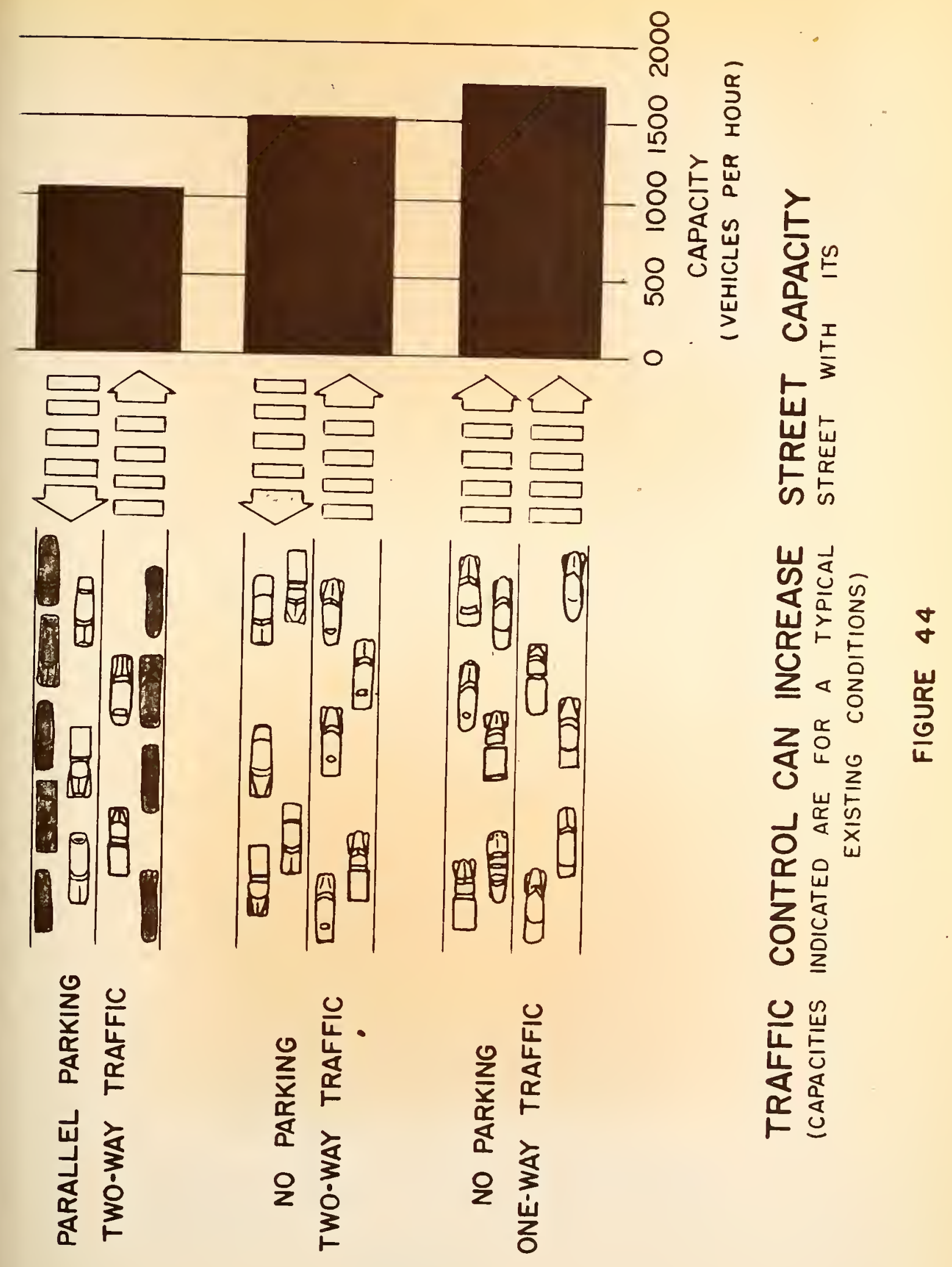



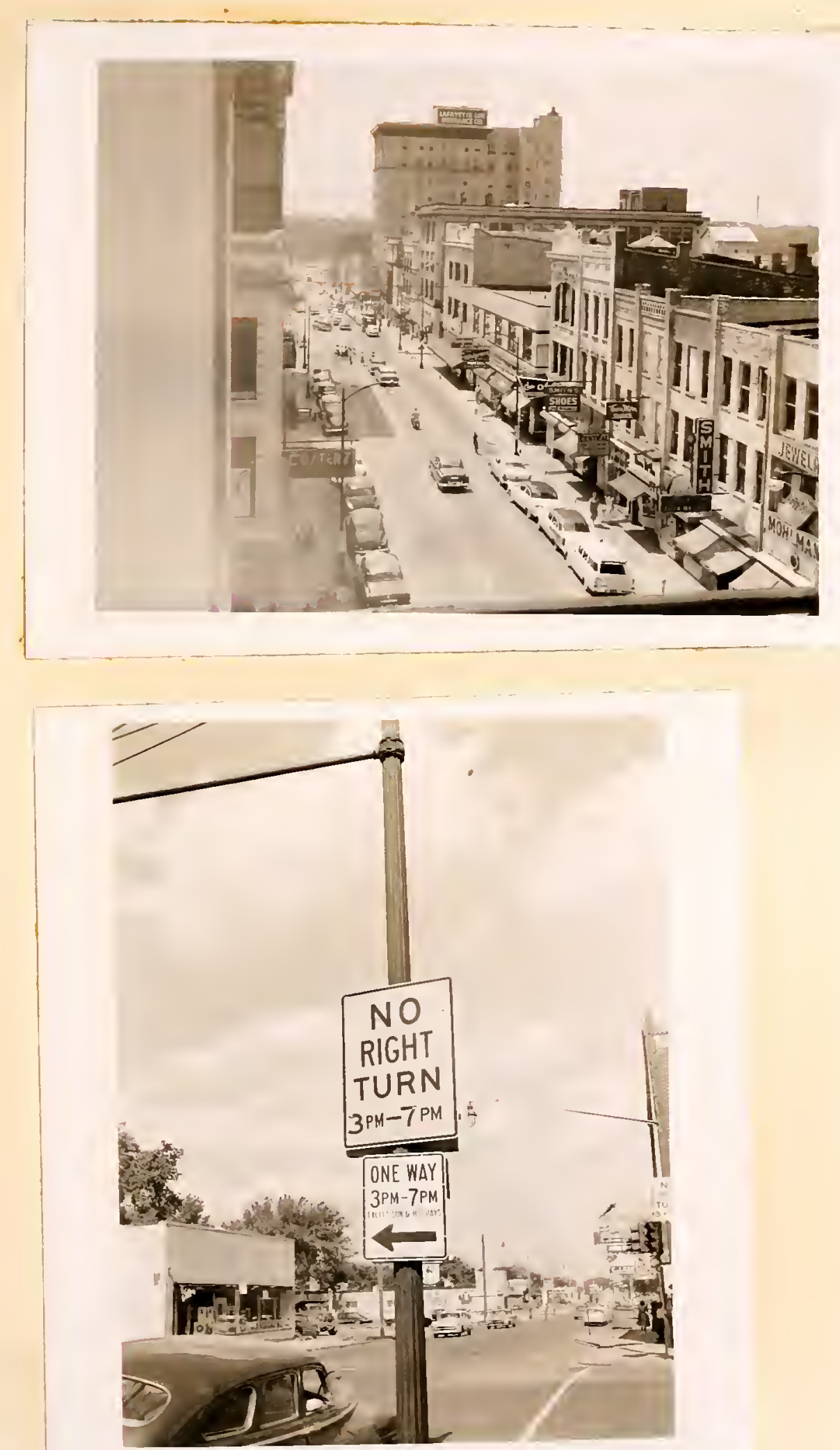

Properly unghed, oncmay gereots may lessen the problens of krenic congestion and de'ay in buey wabsan aroas 
In the proper development of traflic operations, the advice and counsel of a trafflc englneer should ba wisely ueed and standards of the State Highway Department of Indiana should be followed.

\section{Recommendations}

State Highway Department

The highway planning and traffic englneering activities of the State Highway Department should be irstegrated and expanded. An adequate budget should bo establiehed for this activity。

Merking and signing methods can be improved, especlally in the use of reflectorization and in the rapid replacement of signs which do not meet accopted standerdso Signing ir. urban areas should be improved to provide better route merkings through citieg. Iraffic signal control and timing and the establishment of direct routes byopassing uusiness districts should be investigatod. Bettor working rolationships should be established with the cities and colaties by the siate。

\section{Cities}

The larger cities in Indiana can relieve their traffic problems through the application of the pinciples uf traffic engineering. Additional qualffied personnel and adequate inudgets are required in this area. The smaller cities should investigate tile possibility of securing the part-time services of an experienced traffic engineer. Good city = county-state cooperation between the highway depariments can contribute greatly to tho solution of this problem.

\section{Counties}

The countles should establish uniform road identification programs. Marking and eigning on the County Primary and Secondary Systems 
should be improved. Many miles of heavily traveled County Patmary highways badly noed marking for centerlins and nompasing zones and proper signing. Good county-cityostate cooperation between the highway departrents is essential. 
Chapijer VI

SAPLTY

\section{Highway Accidants in Indiane}

The causer and prevention of accidents are the concern of every Inhabitant of the state. Trafric accidents and their effects have been exporienced by nearly every family and are the concern of many departo ments of govemment. In fact, it is one of the prinelpal concerns of highway and street departments, for these agencies are responsible for the safe and officient use of highway faclititis. In most cases rafety is built into not construction by uso of improved standards for many highway features such as width of pavemant, curvature, superelevation, and grades. Propar signs and markings also improve the safety conditions on the highways.

Other safety activities including the keeping of accident records, traffic low enforcement, drivor licensing, dritver control and training prograns, public education, and sefoty organization are the responsibility of governmental unit3. Each agency concemed with pronoting highway eafety is important. Improved highway safety will only result from the combined activities of three programs in which many agencies have a parto These programs are Engineering, Education, and Enforcement-the three I' $^{\prime}$ of hfghway safety. These programs must be supplemented by effoctivo legf slas tion action.

In 1955, 1,145 persons were kllied in traffic accidents on the roads and streets of Indlanam 258 in urban areas and 887 in rural areas (42). In addition, orer 37,000 persons were injured, many sererely。 Tho total economic loss for these accidents including the loss of wages, 


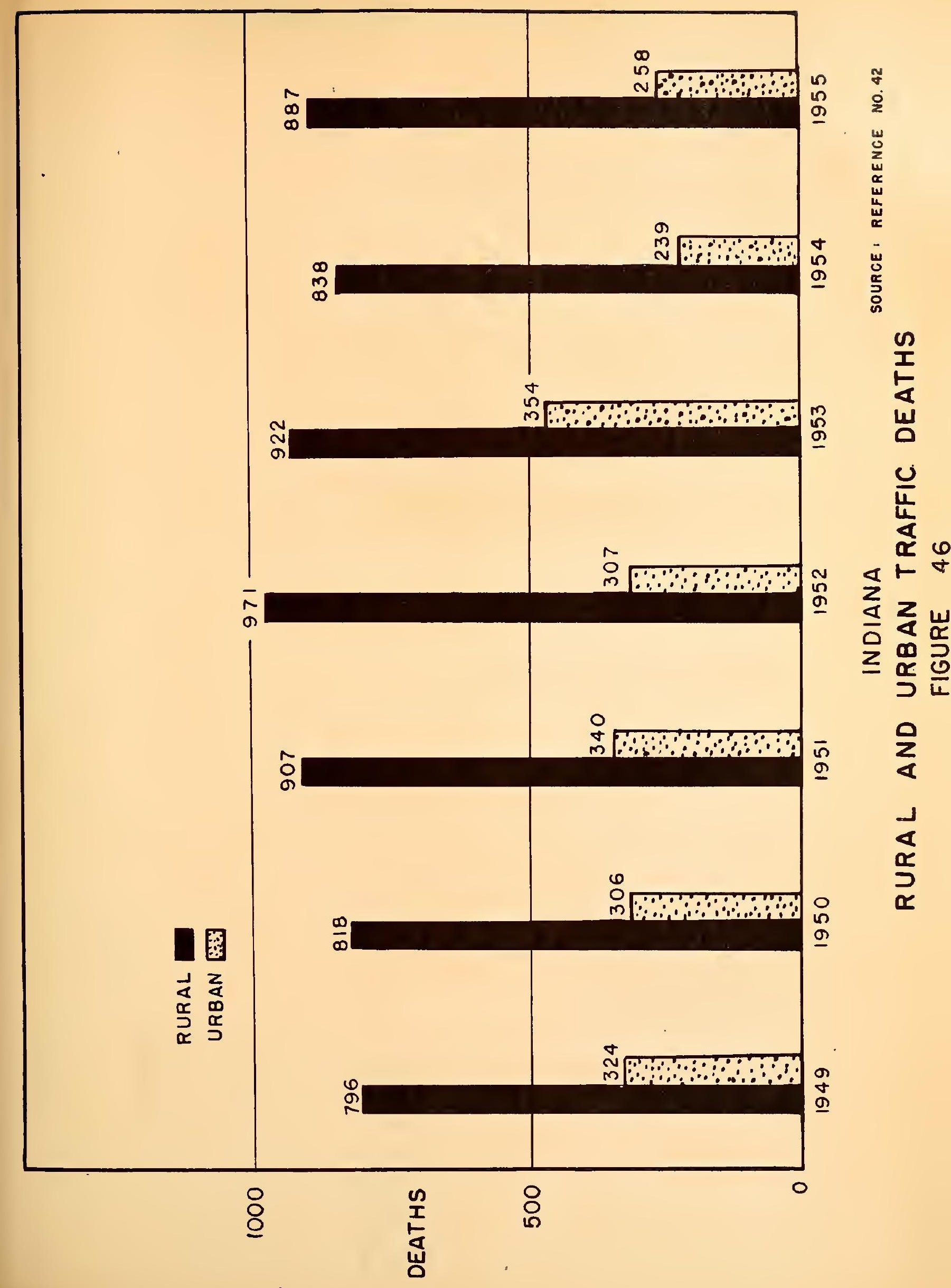


$-118-$

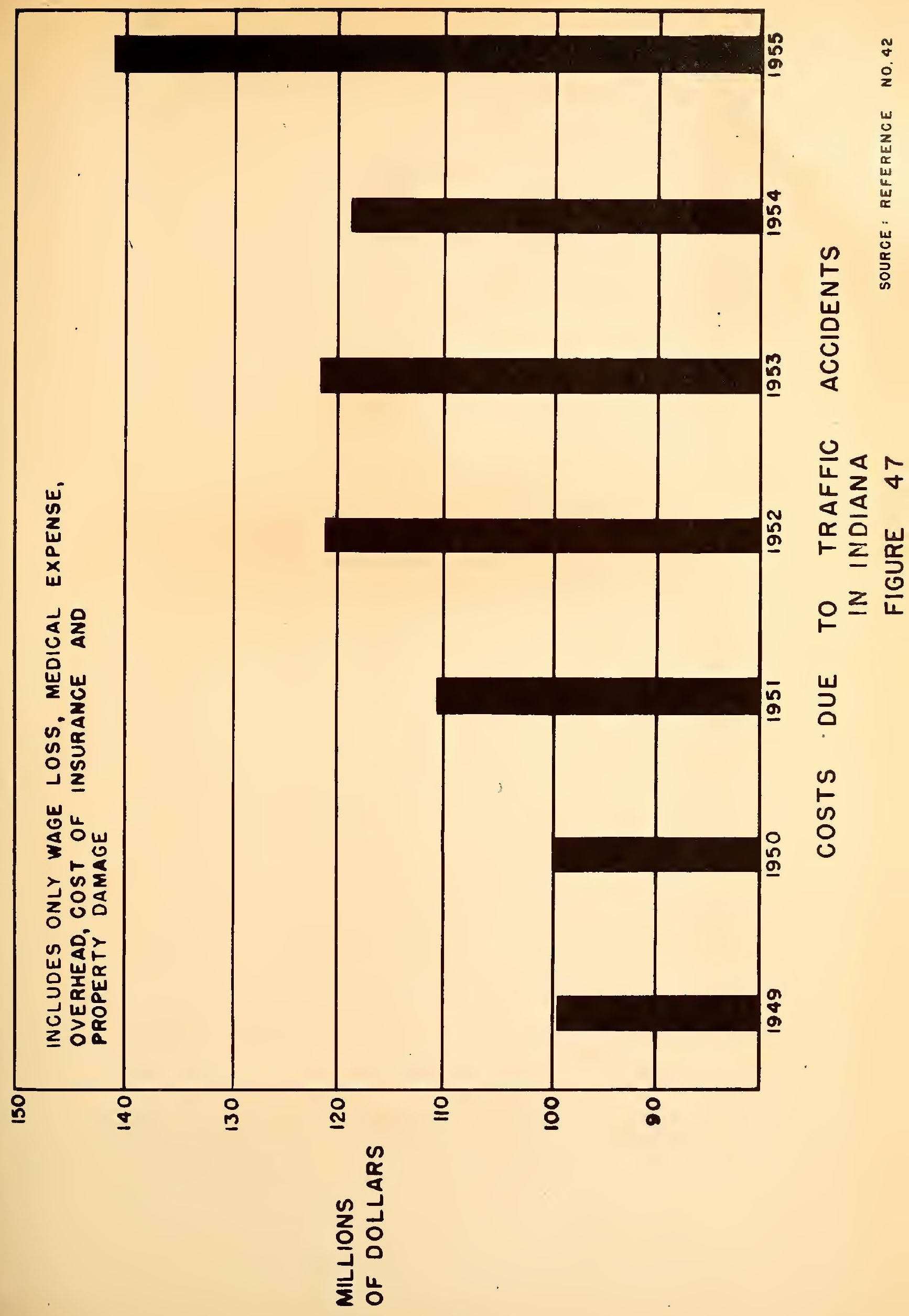


medical expenses, overhead, cost of insurance, and property damage exceeded 140 milizion (42)。The traffic fatality rate for 1955 in Indiana was 6,00 deaths per 100 million vehicle miles while the national ifgure was $6.4(42)$.

The death rate for Indiana has been decreasing during the past ten years but the total number of fatalitios remained nearly constant. The active programs in Indiana in the three $\mathrm{E}^{0} \mathrm{~s}$ of traffic safety are apparently inproving the highway accident dilema; however, a large amount of work remains to be done to further improve this situation. The time has not come when it is possible to say "the job is done." Ever increasing vigilance is still needed。

\section{Engineering}

Adequate highways are safer highways, and there is much evidence to prove this statoment. Mang things can be done to provide adequate highways through planning of future profects and effectsve operation of existing facilities through traific engineering。 Highway inadequacy and highway safety are closely related and elinination of deffciencies will do much to reduce accidents. It has been estimated that the proo posed interstate Syatem 111 reduce accident fatalities by 3500 lives annually in the United States and wl1l result in an annual economic savings of $\$ 350$ million $(62)$ 。

Modemization of inadequate highways can result in lower accident rates on all gystems of highways. In a recent study conducted in Connecticut estimates were made of the accidents that would have occur= red had the highways been constructed to modern design standards for the trafflc which they carried. In all cases the total estimated reduction 


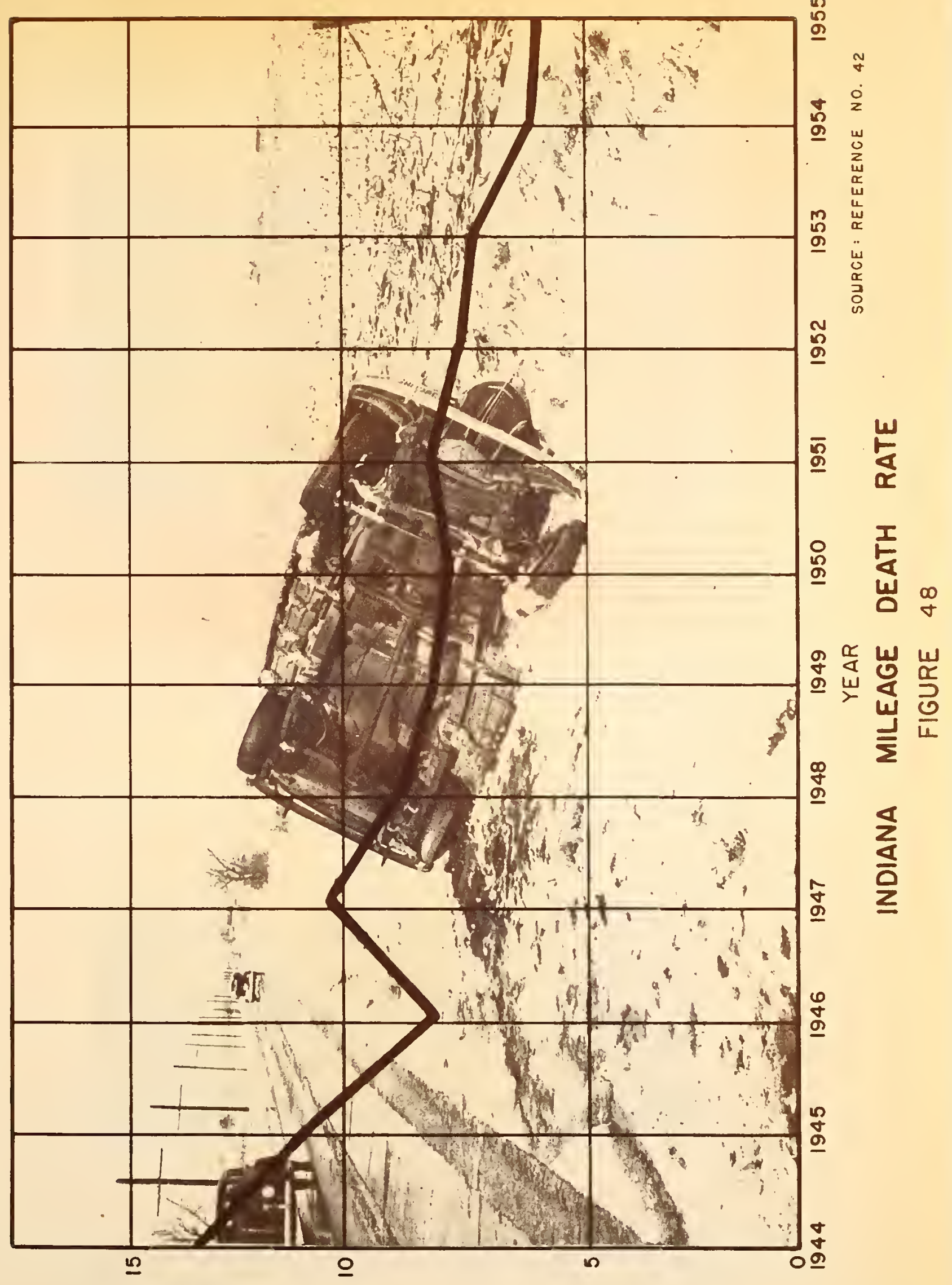

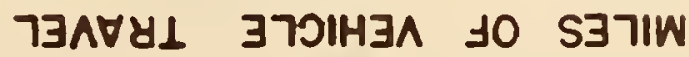



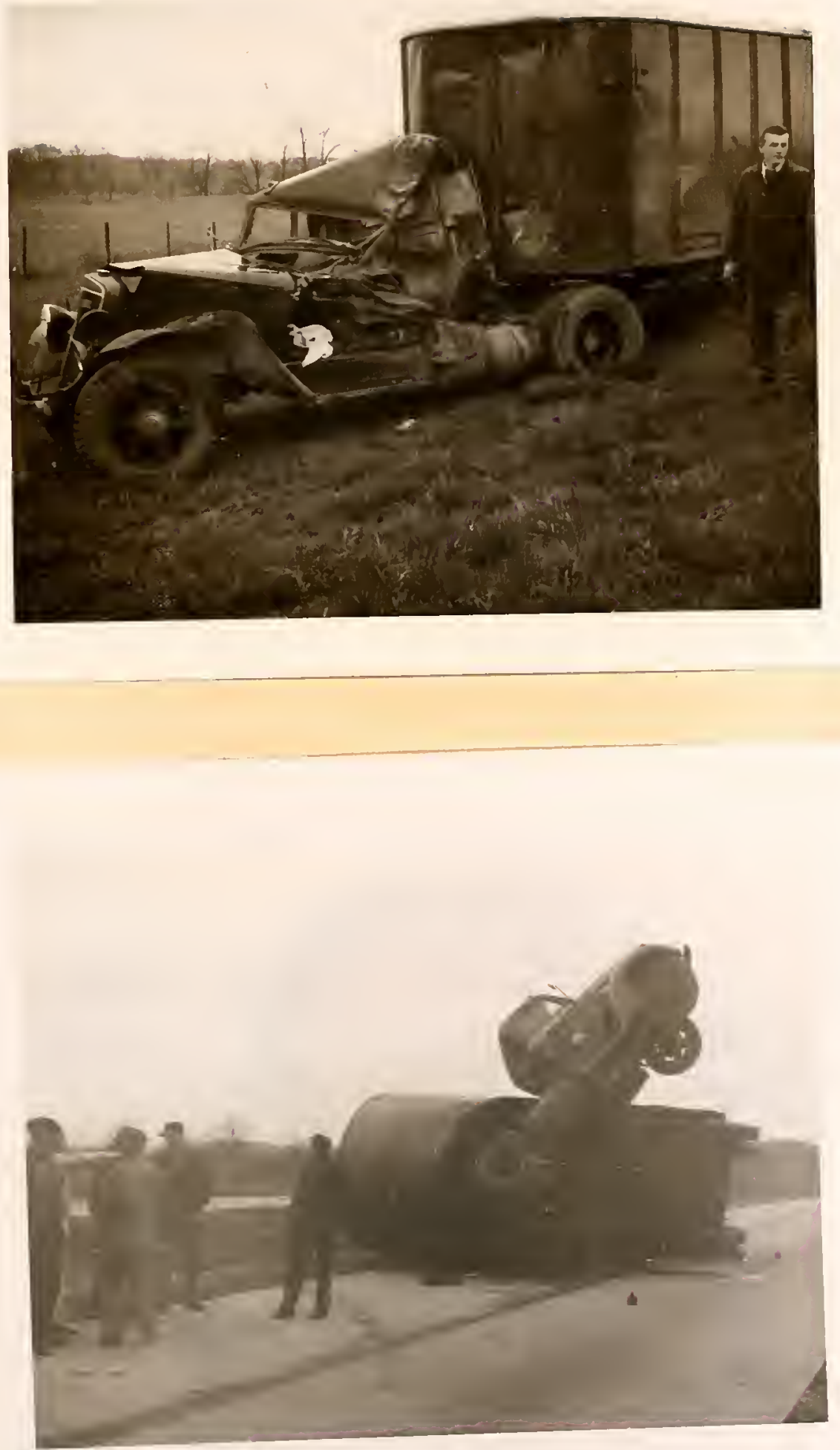

Huge econuric losses, deatis, Injurios, inconvenisnces, and frequent delays in movemant of cargo are the prices paid for zecidents. 

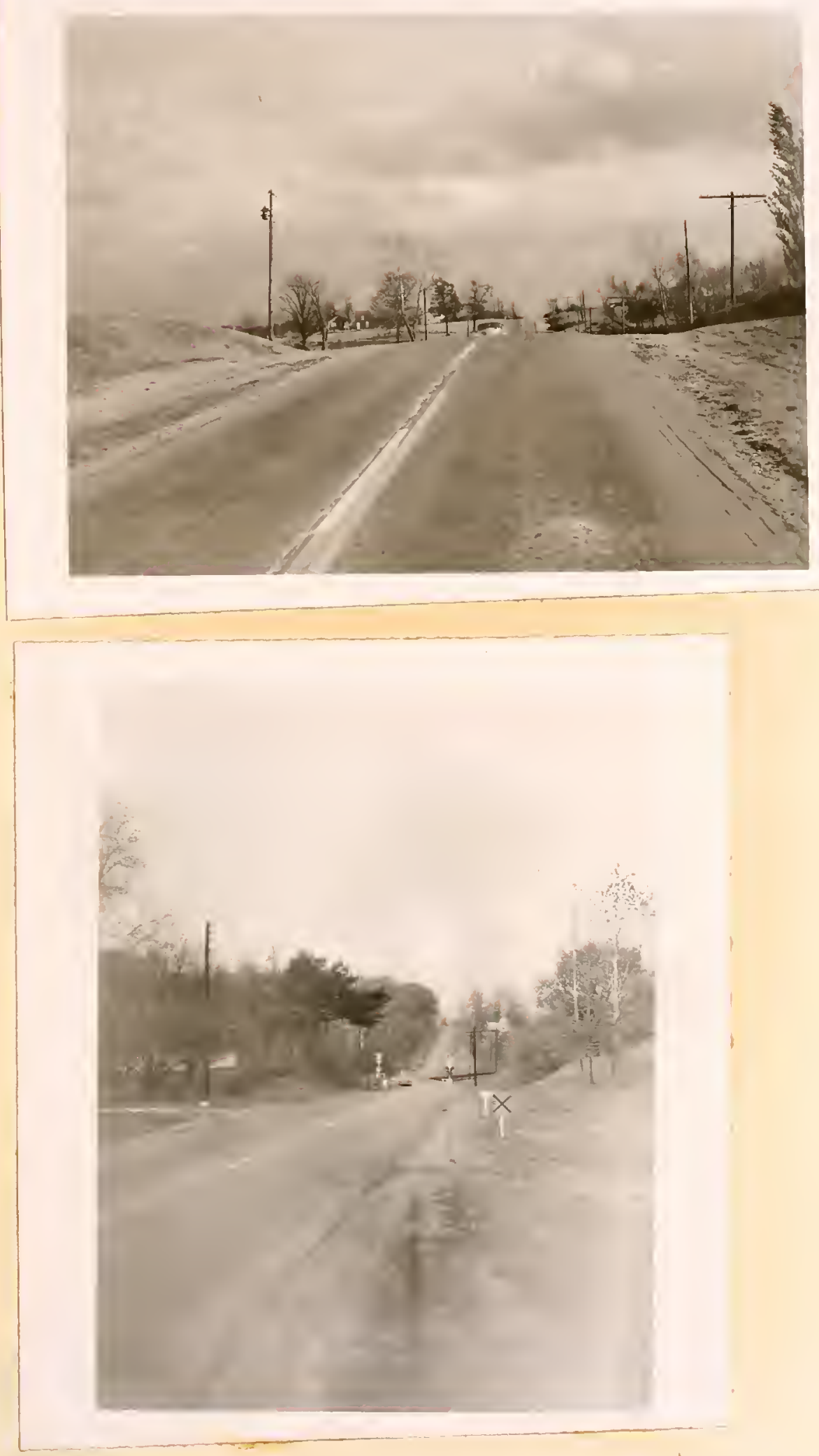

Inadequats alght distance and allgnment typtcal of garlier coustruction jactices restrict free and sefe moverent of venicles. 

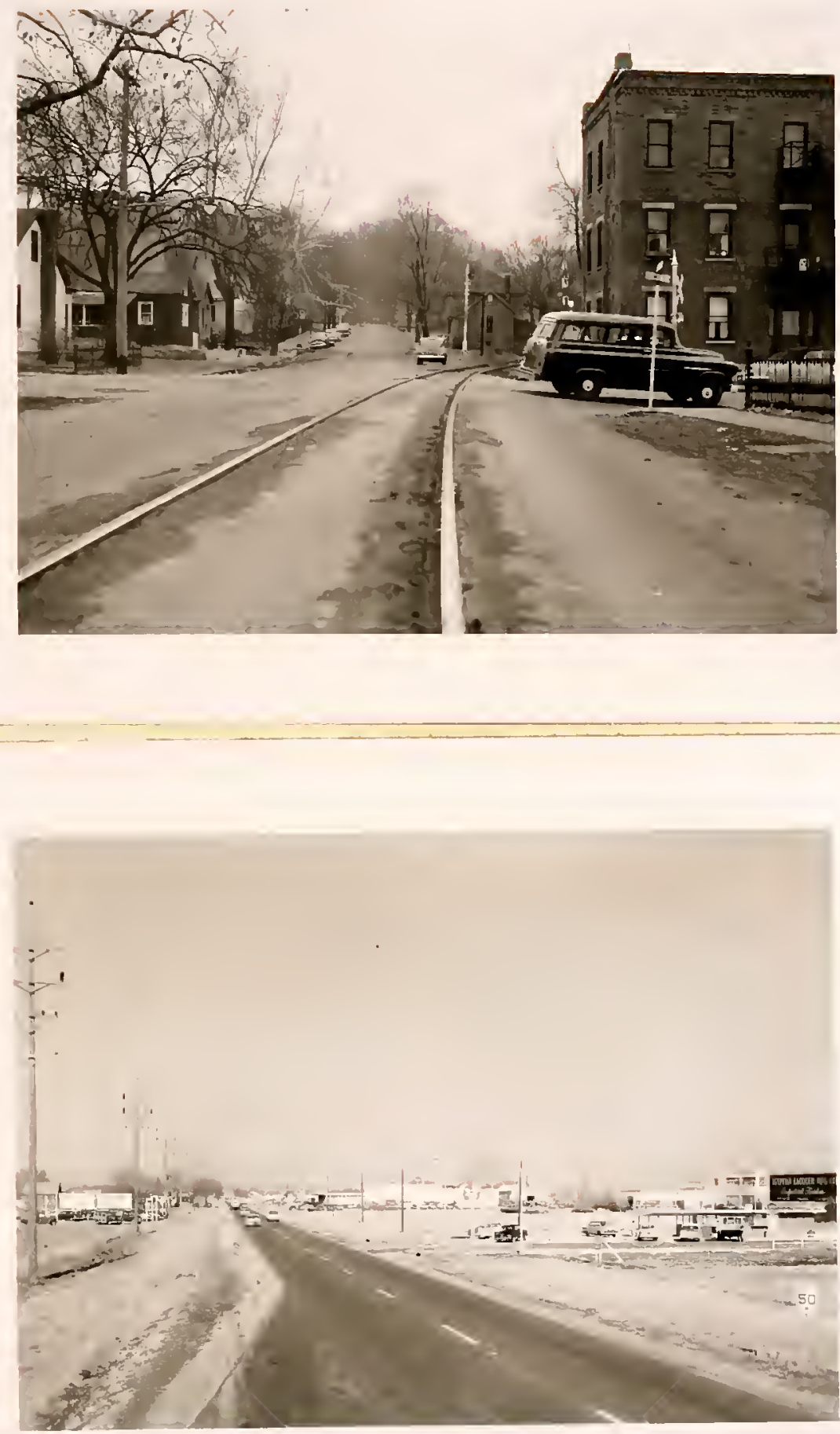

Two serious accilent souices are rajluad erosging

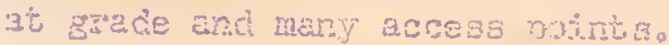


of traffic accldenta zonged from 20 percent for a non-controlled access faclity to almost 60 parcent for a controlled accsis highway on the state highney systen. As overa 11 reduction of 4.3 parcent of 811 accidents was ostirated for the rural and urban syotemo A similar roduct Ion in accidents can be expected on highways in Indians $1 i^{\circ}$ they are made adequate for traffic $(49)$.

Recont studies indicste that control of eccess has a definite Influonce upon accidents. The total accident pate for a nonocontrolled accsss facility is usually gevaral tims as higi as accident rates on controlled aceess highways. Fatality rates on four-lens divided highways with no control of access have been found to bo four times greater than fatslity rates os highirgys with full control of access (8). As expected, a substantial recuction of right angle collisions occurs on controlled access highways beceuse of the elimiuation of roadside con flict coused by grade intersections and private driveways (48)。 of course, the reduction in accident rates cannot be totally attributed to controlled access, but certainly the separation of highway and ratlroad Intorgations and elinination of private driveweys have considerable effect。

Highwogs with full control of accegs have reany benefits in addition to accldent peduction. Travel spoeds are highor and groater fuel economy 18 attained in urban areas where congestion and dolay 250 the groatost (8). Their congtruction in an urban area algo causes a reduction in accio dents on other clty gtreets because traffic is diverted from these streets to the xreersio

A1l hs ghway cannot and reod not be constructed to freeway standard8. Operational procedures such as propar marking and gigning, 
channelization, and stgnal installation are a few of the techniques that can also be usad to reduce accidents. In urban areas, almost. 50 percent of 211 traffic accidenis occur at intersections (1). Study and treatment of such high accident locations can help matorlally in reciuc= Ing the intersection accident rate.

\section{Education}

\section{Increasing Action Program Needed}

The seriousness of the traficic alety problem is recognized by various organizations and intereat groups through theis participation In highway safety progreme. On the national level the President's Highway Safety Conference and the Heitional Safety Councll and in Indiana the Governor's Traffic Safety Conritites, the State Police Department, and the State Highwerg Department are anong the rany organizations worke ing to improve highway sefety。

The importance of local interest in traffic safety is evident since most accidents occur within a short distance of the home (42)。 Accident statistics for Indiana in 1955 showed that 73 percent of all collisions and 65 percent of fatal collistons occurred within 25 miles of the residence of the people involyedo Only 14 percent of ali colIi gions and 19 percent of fatal colligions involved people with an outo of shate residence。

Traffic safoty is a community problem, and the effectiveness of its solution depends upon coimunity action. Soveral cities of the nation have developed succossîl plang for comuntty action. Experience of these communities has establtshed a euccessiul pattern for development of a traffic sefety plan. A group of interested public officials 
and community leaders usully initiate interesi in a trafific gafety program. A staff of professional people is alzo obtained to promois traffic safetyo. In the larger cities all of these ectivities are also the responsibility of the Traffic Diroctor of the Department of Iraffic Engineering。 In the ensil cities wthout a traffic engineer, such activities aro usully the rosponsibility of the Traffic officer. Central guidence of safety activities of the various munfipipilities are often provided by establiahing a gonera] acininistrator to coorcinato and In tograte the program on a staterda basis.

A complete tzafic survey and analyatis is an lmportant part of : successful progran of safety. In conjunction with the anaiysis of trafflc movemont, many gidies and activities may bo 1ncludod. Among than are:

1. Tho locations and types of traffic accidents;

2. Tho conformity of local traffic signs and signals with national. and state standards:

3. The conformity of Iocal trafife ordinances with the Model Treffic Oritnance (53):

4o Tho scopo of the trafisic safety program in eity achools;

5. The roed for ostabjishing a public rolationa unto

Education is such an jmportant pat of any successful trarfic safety program that all public information media o radio, television, newspapers, ard adverilsing o should be used. The educational program should bo initiated befors atternoting to solve the imnadiato safety prograns and befors any traffic andysis is mads. Public support is ubsolutely ossentis for the inisial grecoss and, noro 1inortant, tho future success of such a progxem. Active coxunity interest in traffe

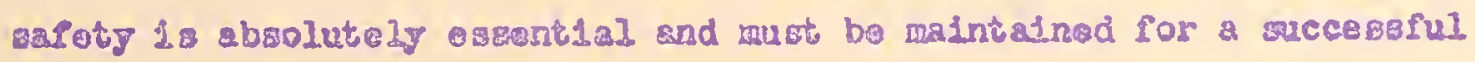
program to surstro. 


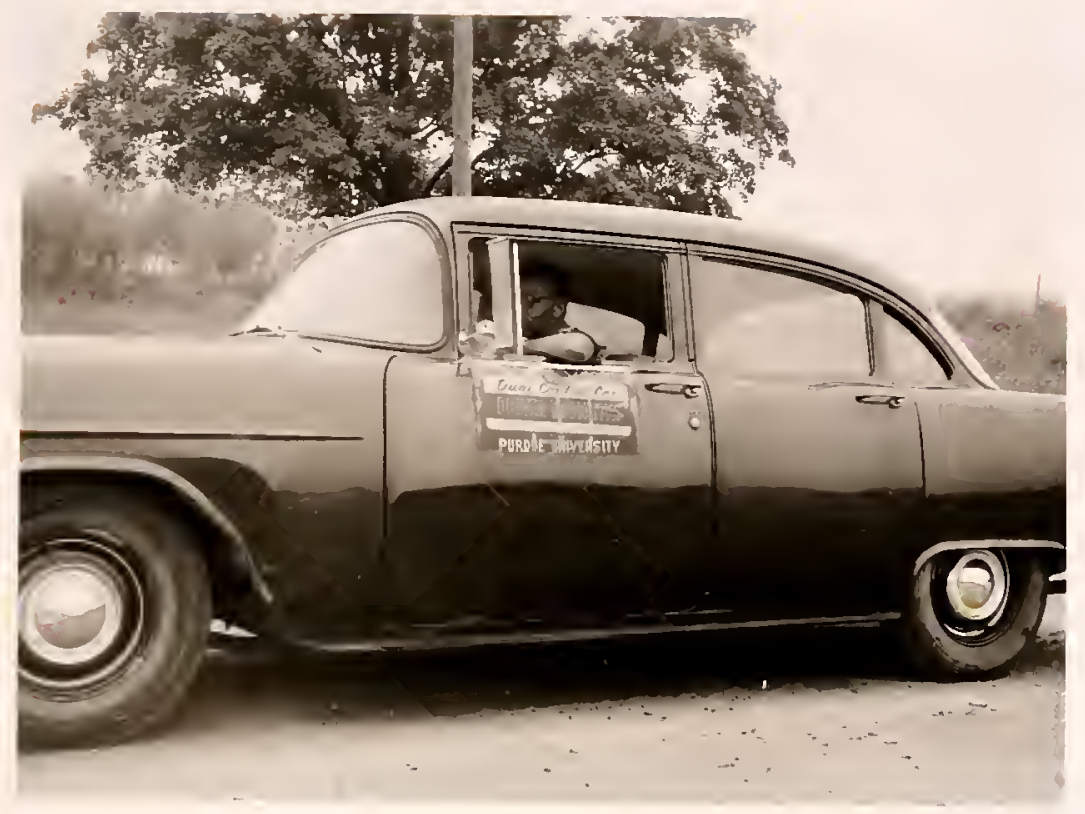

Wany Indiana high schools and colleges offer courses in. diriver education, but only a anall number of schools offer programs which approach the standards reconmended by the National Education Association.

Figure 52 
An analysis, of the results of driver trainting programs, indicates that adequate drives education conges reduce trafic accidents at least 50 percent. Nationwide, at least 6,000 high achools are now offering effectivo coursos in driver education, including bohindothew wheel practice driving (44). In 1955, driver education, including practice driving, was offered in 452 high schoola of Indiana (4h)。 Howover, only a and I number of the ge high achools offered prograss which approached the standerds recommended by the National didusatonsI. Association. Abeut 44 percent of the high schools did not offer driver education in any rorm $(44)$.

The total jearl" cost of an adeouate high school drivor training program in Indiana is estimated at $\$ 1,500,000$. Compared to the total economic loss resulting fron accidents each year, the cost of a driver ecication progran is a small invertment. The required money, however, poses a serious budget roquirement for school authorities. It is bew Lieved by many people that these funds should be secured from highway user sources instead of general school funds and plans have veen acto vanced whereby this money could be raised from traffic fines or driver Iicense fees.

\section{Enforcement}

Engineering and education, however, are not enough to reduce accidents. Adequate laws and enforcement are necessary to produce an effective trafic safety program. Numerous local cases show how effeco t1ve enforcoment reduces accidents and undoubtedly enforcement has contributed to the state and national trend of a lowering fatality rate. Good and unfform laws are absolutely essential for the advancement of 


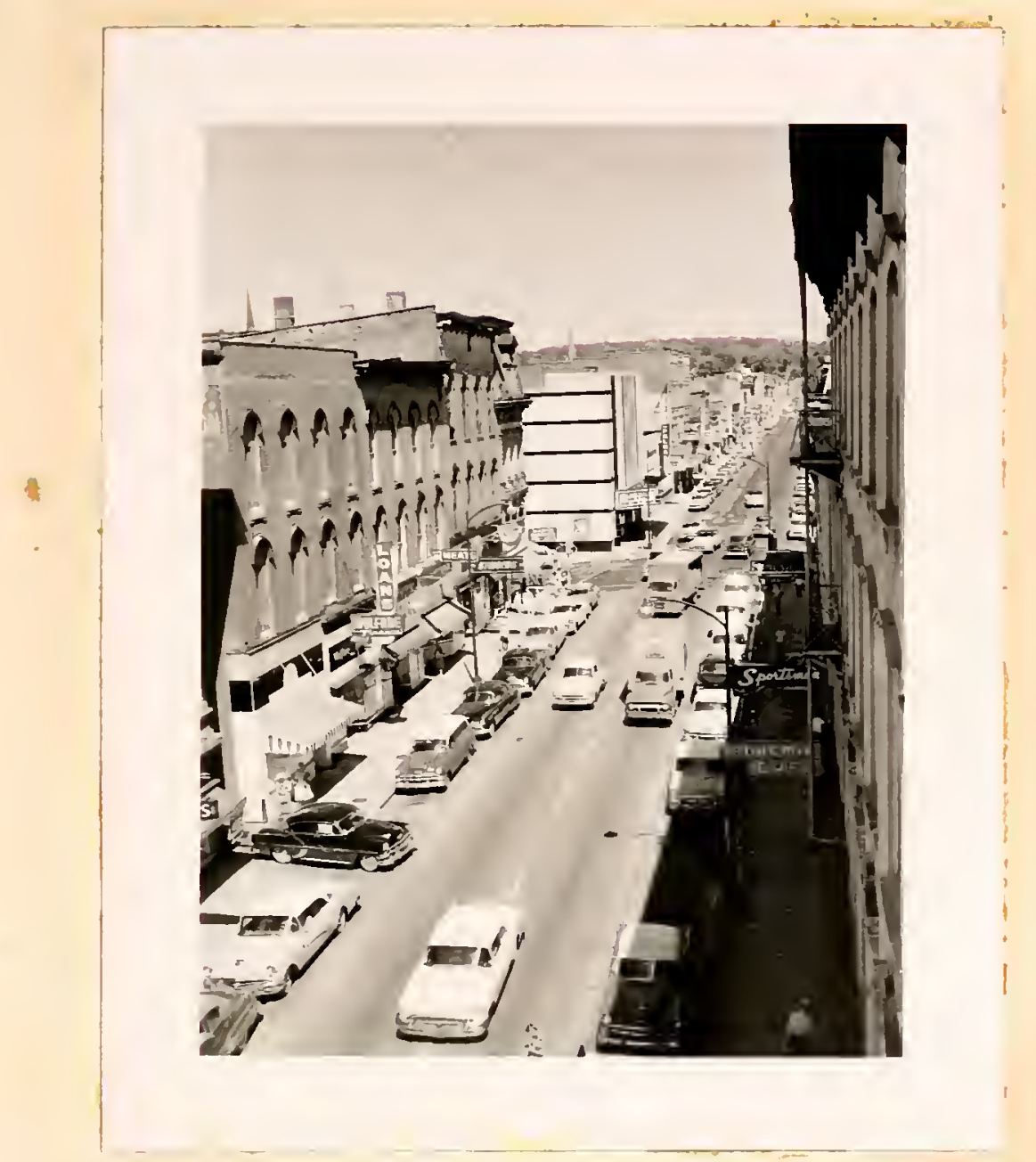

To be most effective, good traffic operationo must be supported by good law enforcement. The firgt truck in the left lane 18 double parked, eliminating one lane of traffie and causing congestion and possible accidenti。

Five 53 
safo and officient highway trensportaido. fccident recorde, driver Liconsing, hlgh school druber training, polfce and court activities, and intesogovernmestal cooperation should bs included.

In genereI, the laws of Indiesa covering mules of the road are in reasonablo conformity with the rules of the road of the Uniform Vehicle Code. For exanple, the state Highway Department designatos rôdways under its authority as "onempy" and deslgnates "no-pessing" zones。 In general, it exercises authordty over traffic cuntrol on urbar extensions of state highwajso

Mrny commurities in the state, hosever, have not adopted traffic Laws which canform to the Lodel Trafic Orcinance (5j). Esch eity should Invesilgato its preser; torafflc laws and make those revicions which are - necessary and consistent with state jaws. The best wy to get the job done is by informed comounity action. Adequato and unifom laws througho out the cities of the atate rould be an effoctivs step in the direction of inproved trafic sapety.

\section{Accident Records}

For many years Inciana has had a compulsorg accident reporting lawo This law has done much to jrovide adequate accident recordso Information for more efrective onforcenent activittes and also necsssary deta por propor traffic englneering noasures have bean obtaingd from theas iecordso An accident spot map is produced each prear by the State Hightay Departo notit for the rural atate systems from information obtained from these reports. Locations of satal and personal property or injuxy accidents. are shown. Intersections with poos accident experdence are shown and appropriate corrective measures can be mado. 

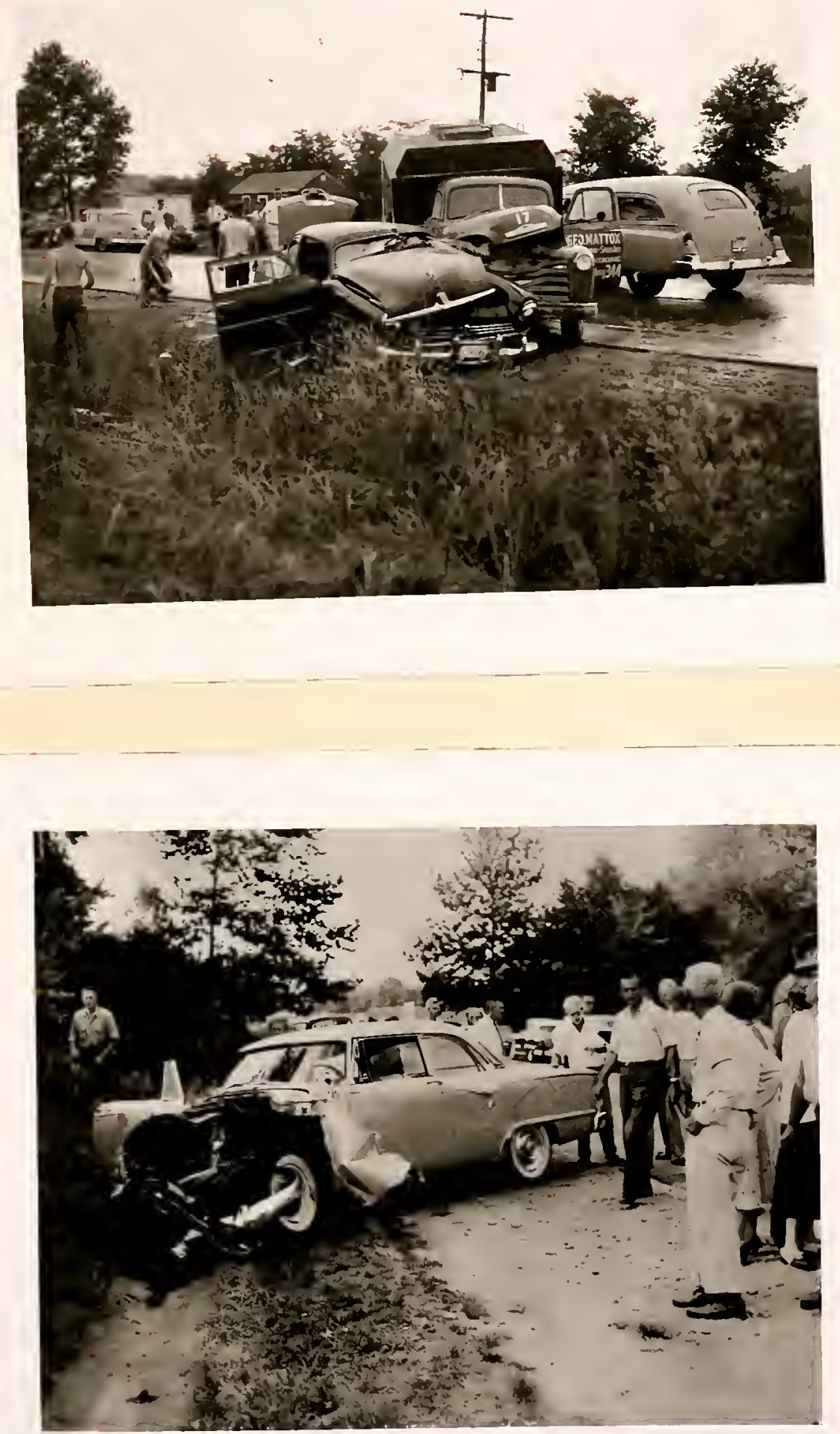

Inadequate highways take a severe toli. In 3 wes lost and property desirroyed. 
The use of accident records in enforcemert and engineering varies from city to city. Some cities effectively utilize accident reports in the dovelopment of spot meps to determine locations where enforcement ox traffic englneoring proceduro are required. Othars have Ignored the use of such raluable information and have little knowlesge of their accldent problen or 1ts solution.

Accident information on the county highway systems is very poor and county highway departments havo done Ifthie to utilizo available accident Information. Fatal accidents are reported but many personal psoperty accidents are never reported. Evidence indicates that the death rate is higher on this system than on rural state highways although apeeds and exposuro \&o occidents are lowsr.

\section{Susmmary}

The elimination of ingdequactes on highreys in Indiana will reduce accidents. Sone estimatos indicate that 40 percent of 3.11 accidents could be avolded if the highway grstems are Improved to modem design standarde (49)。 Control of access on the Interstate and Primary State Hgtays will bo the greatest contributor to a lower accident rate (48)。 Uncontrolled roadside development has undoubtedly caused many sectione of highway to have high accident rates.

A wellolnformed prblic can alleviate the increase in accidents and the resulting deaths and economic 108ses. A clearly defined program. should be established in each city and county so that information on irafflc safety is made available to 211 news media. Through coordinated planning and an efficlent cooperative program on the state and local level, action can bo materially increased. 
The beneIits of an adequate dpiver training program have bogn proved In many sitates. Cver oneothird of a milizion students were ono rolled in high school driver training courses throughout the nation in 1954 (44). However, this Iigure sepresents only a smeng portson of the potentiel drivers in the high school age group. Driver education proo grans should be establighed in more high schools and adequate funds should be provided to meet the needs of this prograra

An adequate enforcement program is also essential to a euccessful highway safety program. Uniform laws are essential to effective onforcemont and most cities nead to revise their traffic laws to conform with the Model Traffic Ordinance (53)。 Good accident records are recessary In an effective safoty progran and whon used in conjunction with traffic ongineering procedures will reduce accidents. Most counties and aities have not attgapted to kgep and utilize accident records。

The highwey safety problem is indeed dirficult. No ons soluticn can be obtained, and man, with his human limitations, will always havo accidents. Sheh can be done, however, to prevent many of there from occurring through adequate engineering, aducation, and enforcement. 
Chapter VII

HIGHT:AY NEEDS

State HLghway Appraisal

A mile by mile inventory of the state Highway Syatem was performed In the winter and spring of 1955. Such Information as type and condi= tion of road surface; types, condition, and thickness of pavement; ypo of soil; age of parement; sight distance; and degree of curvature fo: each section of highway was determined. Coinplete information on bridges and railroad crossings was also complledo This voluminous mass of data was punched on IBM cards to permit rapid and accurate tabulation and computation. Such information as highway capacity, accident rates, traffic and structural characteristics, and remaining surface Life was determined。

All the important geometric and structural elements of the higho way were then analyzed in relation to the present and future traffic demands. Tho inadequate elements for each section were determined by comparing tho present highway with the tolerable and design standards for the class of highway of which the section was a part. The sum of the needed improvements for all sections of highway, both urban and rural, represents the "total needs" for the State Primary, Secondary, and Urban Systems. The requirements of the Interstate System, however, vere dew termined by using data from a detalled analysis made by the State Highway Department. Complete information, a portion of which is shown on Figuro. 55, was tabulated concerning the geometric and structural characteristics of each section, including adequacy of protection at rafluoad crosings and bridge information. 


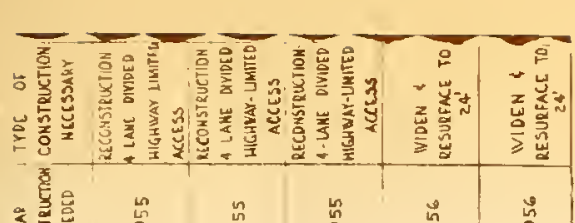

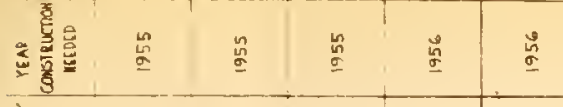

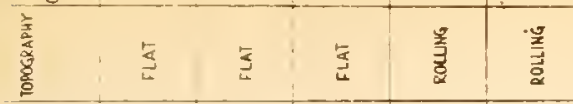

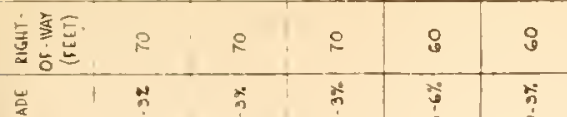

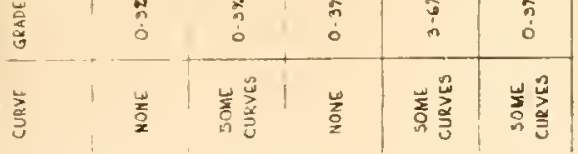

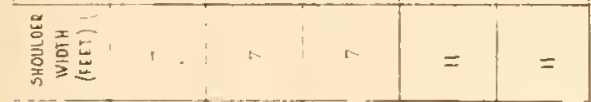

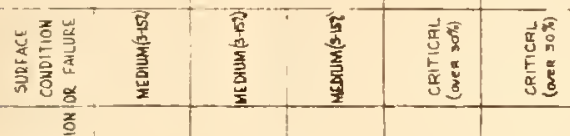

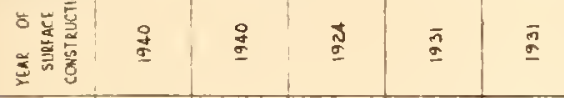

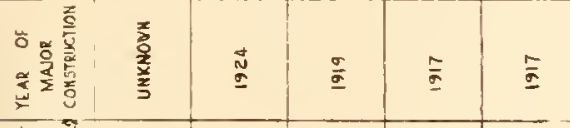

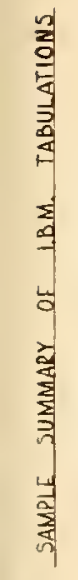

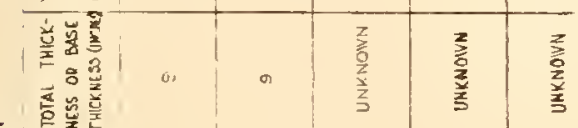
z을

일

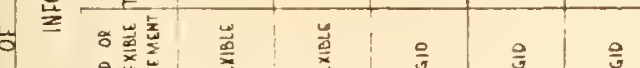

\begin{tabular}{|c|c|c|c|c|c|}
\hline 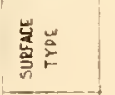 & $\begin{array}{l}\text { 意 } \\
\text { 尊 }\end{array}$ & 喜 & 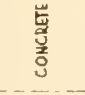 & $\begin{array}{l}\text { 苟 } \\
\text { 总 } \\
\end{array}$ & 崖 \\
\hline 旁 & 善 & 素 & 喜 & 竧 & $\stackrel{\underline{3}}{\underline{3}}$ \\
\hline 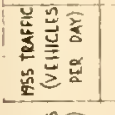 & $\begin{array}{l}8 \\
\text { N } \\
-\end{array}$ & \begin{tabular}{l}
8 \\
\multirow{9}{*}{} \\
$\simeq$
\end{tabular} & $\stackrel{8}{8}$ & $\stackrel{8}{4}$ & 亭 \\
\hline 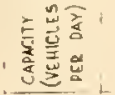 & $\varepsilon$ & 焉 & $\substack{\hat{i} \\
i=1 \\
i}$ & $\begin{array}{l}8 \\
4 \\
4 \\
0\end{array}$ & $\begin{array}{l}8 \\
\text { gे } \\
\end{array}$ \\
\hline 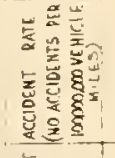 & $\underline{\Phi}$ & $\overline{\underline{\alpha}}$ & $\underline{\underline{\Phi}}$ & $\stackrel{n}{N}$ & $\frac{2}{N}$ \\
\hline 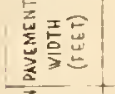 & $\approx$ & $\vec{v}$ & $\approx$ & o & \\
\hline 旁言壳 & $\stackrel{\sim}{\sim}$ & $\stackrel{n}{\circ}$ & $\hat{n}$ & : & $\bar{z}$ \\
\hline 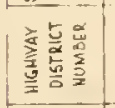 & 童 & 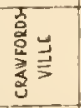 & 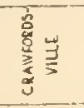 & 憘 & 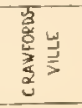 \\
\hline 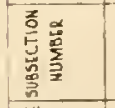 & - & - & $\sim$ & - & $\sim$ \\
\hline 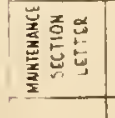 & $\overline{\dot{x}}$ & $\tilde{\ddot{x}}$ & $\tilde{\dot{x}}$ & \pm & $I$ \\
\hline 岁蓄 & F & $\begin{array}{l}7 \\
3\end{array}$ & $\begin{array}{l}7 \\
3 \\
3\end{array}$ & $\begin{array}{l}3 \\
a \\
0 \\
\end{array}$ & $\begin{array}{l}7 \\
*\end{array}$ \\
\hline
\end{tabular}

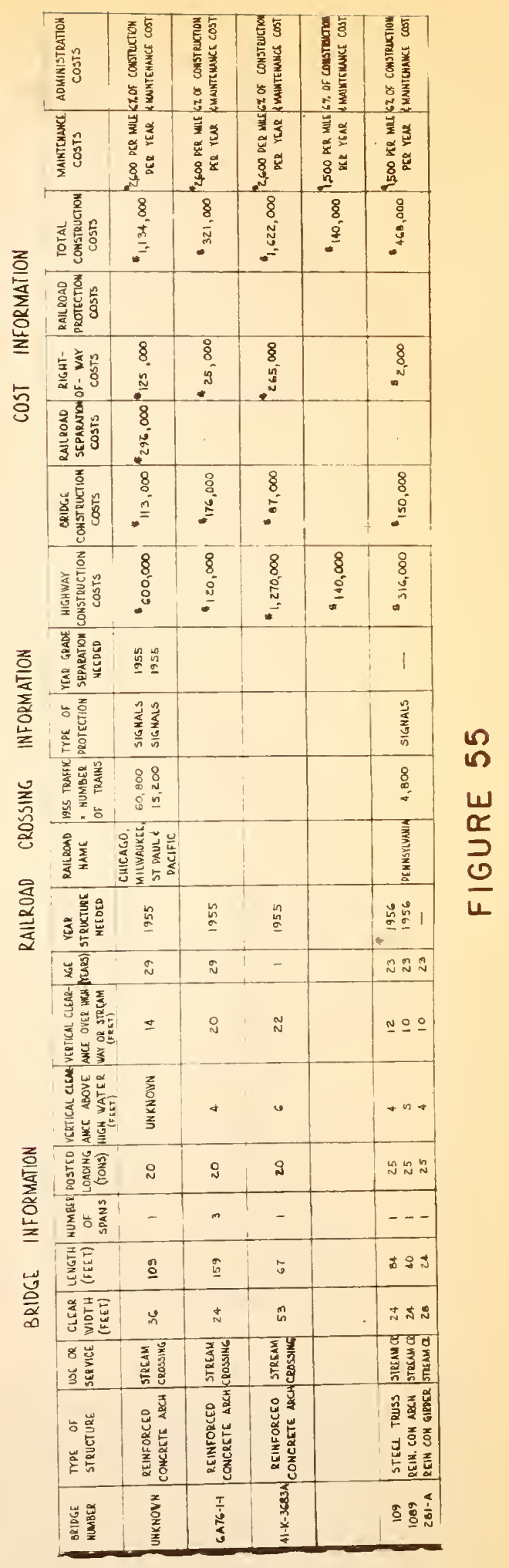




\section{County Highway and City Street Appral sal}

The requirements of counties and cities for roed and strest.imo provements were also determined. Time and financlal requjirements made it Impossible, however to make detailed inventory of the 87,600 miles of county roads and city streets. Furthernore, inadequate records of construction and maintenance and the failure of counties and cities to provlde long-range planning made impossible a completely objective appraisal of the deficiencies.

In order to obtain an estirate of county rosd inadequacies, data from two Indiana counties were used as a semple. In these counties, detailed information on road and bridge conditions was ovaluated, and the noeds were determined. A study of the requiremants for improvement of county roads in adjoining states as reported in their recent needs otudies also provided supplenental information helpful in making an estimate of the county highway picture.

The demand for city otreet improvements falls into two categories * those on streets that are urban extensions of the State Highway System and those on streets that are the complete responsibility of the cities。 The needed improvements for the urban extensions were determined as part of the state highway study. These improvements constitute a large portion of the state highway requirements becsuse most of the costly construction is in urban aress. Many miles of expressways are needed In Indianapolis, Fort Wagne, South Bend, and other metropolitan areas of the state.

The evaluation of other city streets was done by studing the not= work of streets in representative citios of several population classes. 
The percontage of street mileage in eaci of these cities that should be classified as arterial and local access streete was determined. The cost par mile of improving the streets of a typical city to adequate candition and of providing any additional capactty necessary was determined from studies of such Lmprevements made by engineering organizations for a fow cities, from estimates made by several city ongineering departments, and from egtimates made by state highway needs studies in nearby states.

The estimates for needed highway improvements for counties and cities were based on evidance that is not as complete as the information for state highways. It was not possible to obtain good information from counties and cities for this siudy and it will not be possible until botter data are developed by the counties and cities. The highway needs of countles and cities, however, are roported on the basis of a projection and/or expansion or the best information available.

\section{Cost Fitimates}

On the state highway systens, estimates were computed on the basis of unit prices for grading and drainage, surface and base, structures, and $\mathrm{x}$ ght $\mathrm{O}$ owsy. In most of the city stroct and county highway est1nates, the costs for various types of Improvements were computed on the basis of average unit cost per milo.

AlI costs ware based on the 1955 price levels for construction and maintenance. Bid prices for 1955 contracts on the State Highway System were obtained from the Indiane State Highway Department. Istimates of. costs for county and city construction and maintenance were obtained from a study of costs of improvements in counties and cities. In some 
ceses the cost gtudied were not for 1955 but were adjusted to the 1955 level. In all such caseg, the Bureau of Pubifc Roads cost Inder was usod to adjust these cost 8 . An adjugiment in the jearly needs for the future was not made because fluctuations in the level of costo cannot bo determined with accuracyo

\section{Noeded Improvements for the State Hi ghway System}

Although coly a emall porcentage of tho prosently deficient infleo age in Indlana is on the rural Etete highways and their urban exters Dions, correction of the deficiencies on the state systems requites 75 percont of the money needed to eliminate ald prevent doficlencies. Furthermore, the elimination of present inadequacies on the Intorstats Sratem requires 61 parcent of the total fonds needed for the state systems and 46 percent of the total funds noeded for all systens. The high cost of elininating inadegizate highway elements on the stata systems is because of the high concentration of traffic on these gystems and the resulting high construetion costs, especially on the urban sections.

\section{Inierstate System}

With the notable excepition of the toll road and \& fer miles of public highways in the Calunat ara, Indiana has very fow miles of highway winch roet the design standards required for the 1,100-aile In torstato System. This Sygtom, therefore, aust bo essentially "built iscm Beratch"。 It will be necessary to relocate or reconstruct nearly every. milo of the two-lane and fourolarse divided highways that presentiy are designated as the Interstato Syotemo Most fourolane divided highways on this Sygtem mas bo reconstructod becruse some geometric elenents 


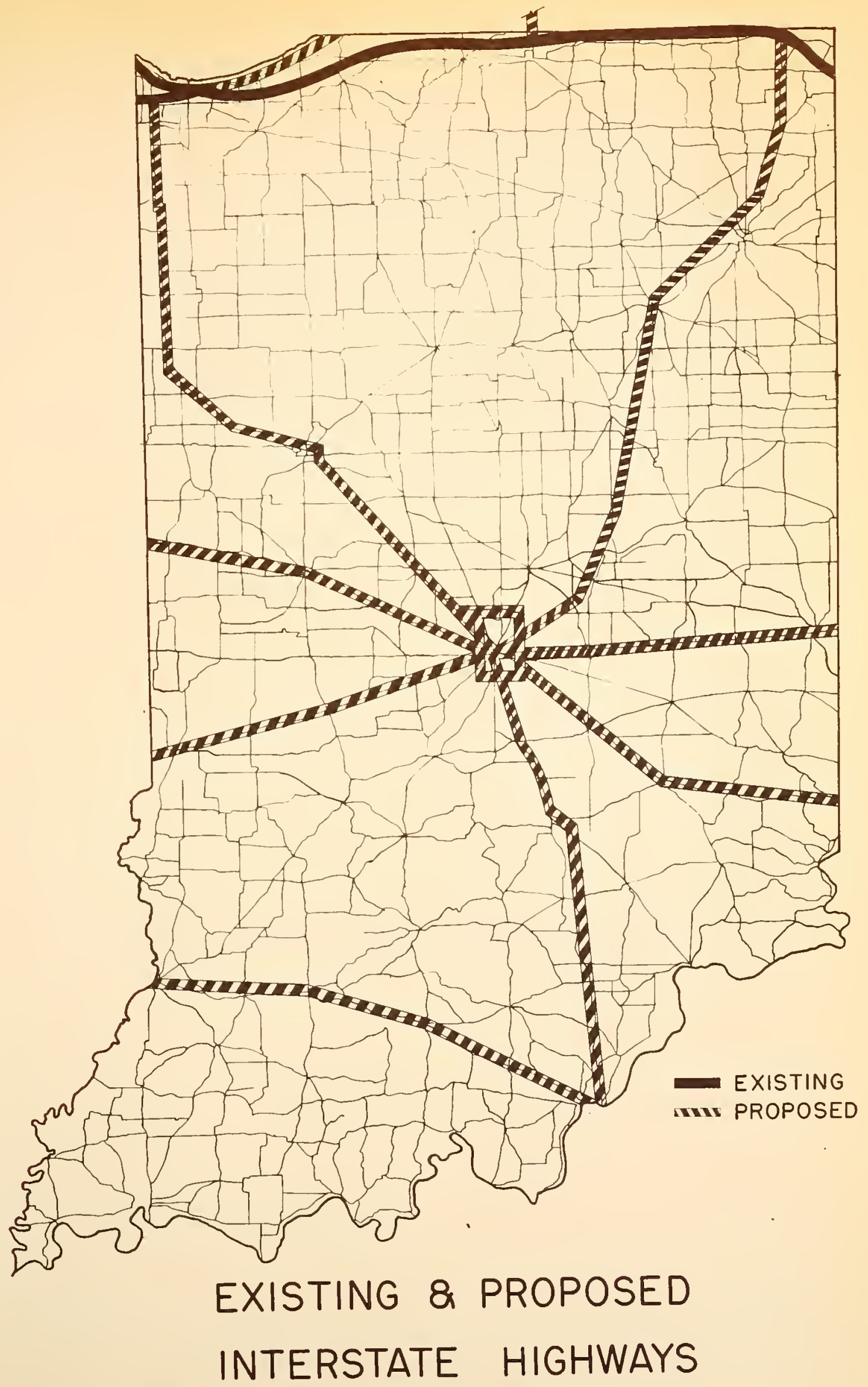

FIGURE 56 


\section{TABDS ?}

\section{Interstate Syster ificages and Costs}

\section{Mijeage Masting Iesign Stendards}

Location

Costomilitons Number of Miles

Rure] Urbans

Indiana Toll Road

Trositate Expressway

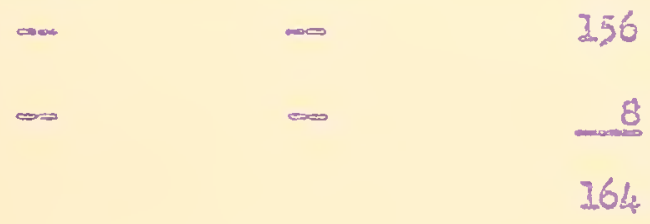

Me IEage Not Heatinf Dastgr Stardards

\begin{tabular}{|c|c|c|c|}
\hline Rexaircier of Systom & $\$ 783$ & 5274 & 936 \\
\hline potal & $\$ 783$ it & $27 \%$ & 1,100 \\
\hline
\end{tabular}

* Ravised costs as determined by Sectlon 108 (d) Strdy conoucted by State hizghroy Departrent of Indiana. 
are rot adaquate and none of this rileage has comploiely controlied access, Table 7 presonts the mileago which njets design standards, ard the cost of ihe present Iy naeced inprovements on tho renainder of tho Sytamo

Thers are 150 mileg of wobai and 766 miles of rusal mileage not meeting destron standards, and the urian mijeage accounts for 26 percext

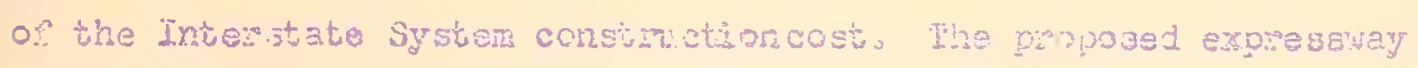

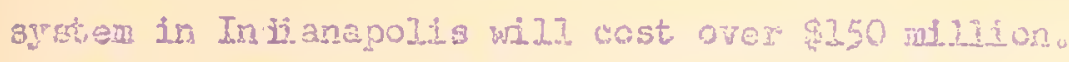

\section{Auzze Primary ard Secondary Higr Har}

Table 3 lists presenty reeded improvenents on the ruxal stato Primaxy and secondary Highway Sytams The costs ar"e also very high, but are less than the rvya. Irteratate Systen on a cost per mile ba:is.

Type of Defiukency and Worl Required

The deficiencies wilch mat:e the state highways intolerable have been clesaffed as capacity, atructurel, and a combination of capacity and structural. Table? shows the type and extent of sone of the current deficiencies, Many deficiencios on the Ironmary Systern are caused by inadequat capacity or siructurel inadequey thile those on the second: amy syatem as, as a general tule, structural deficiencieso one of the notable features show by these date $1 \mathrm{~s}$ the poos strictural sondition of the state systems. It can bo observed that. many miles of highray built in the early 1930"g now need resurfacing or reconginucton and that mang structu:cs, butilt chroing this era, are now functionally obsoletso

The cost per mile of correcting caracity deficiencies is severel tims the cost per wle of correcting structural deficiencies because 
TABLE 8

\section{Present Deficiencies and Costs of Irourovements}

\section{on Iural Stete Highrays}

Item

Total Miles in Sygtom

MIles Deficiont

Percent Dopicient

Doficlent structures (NOo)

Estimated Cost (Milions)

Roads

Total
雨192

$-62$

\section{Site Hrimary}

3.600

1,057

29

526

752

$\$ 146$

72

218
Tote1

9,000

2,832

31

1,278

$\$ 338$

134

4,72

* Does not include Interstito System 


\section{TABLE 9}

\section{Types of Prosent Deficiencies on}

\section{Rural State Highweys *}

Type of Doficiency

$$
\text { Capacity }
$$

Structurgl

Cepacity and Structural

Total

$\begin{array}{rc}\text { yijles } & \text { Percent } \\ 212 & 7 \\ 2,349 & 83 \\ 271 & 10 \\ 2,832 & 100\end{array}$

* Does not include Interstato Systen 
TABLE 10

Trpes of Present Construction Nesded and Costs on Rural State Highways *

\section{Type of Improvements}

Resurfacing

Widening and Besurşacing

Reconstruction

Relocatios

Siructures (Number 1278)

Total
H.Le

26

1,391

1,351

64

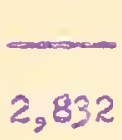

\section{Cost $=$ Hit1ions}

2

64

259

14

133

472
Percent of Total Cost 1 14. 54 3

$\frac{28}{28}$

100

* Does not include Interstate System 


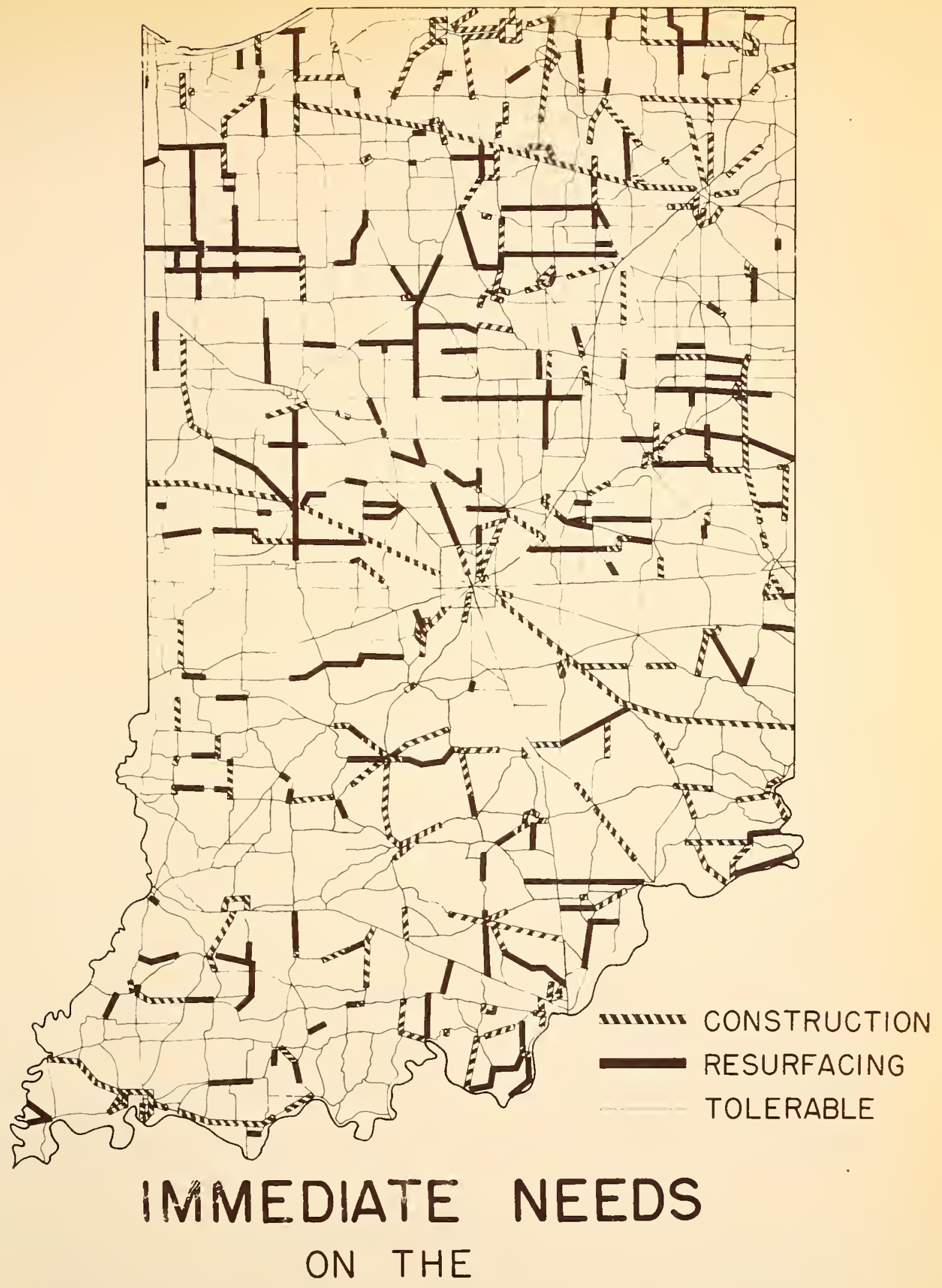

PRIMARY AND SECONDARY STATE SYSTEM 
mony of the capacity deficiencios require expensivo four-lane divided cnnetruction. Many of the structural deficiencies of the pavoment, on tho other hand, can be corrected by a now surface and baso or by seo arfacting。

The types of congtruction to renedy these deficiencies are given In Table 10. Reconstruction cortemplates using at laast part of the old roadbed for the improved roado In some cases, hovever, highwey cannot be locatod on the old aligmant because comirolisd access is requiredo Figures 58 and 59 indicats the existing needed improvenents on the rural Primary and Secendary Syutsms. Of the 2,832 miles needing Improvements, nearly 450 miles requixe four -1 ane divlded conturiction。

Defleiencies in 15 year

The lomediato correction of oxisting deficiencies on the rural state systems is Impossible; psinaps 10, 25, or 20 yeass are required, depending upon the oconory, fiseal policy, and the availabiltty of man power. Durlng this poriod of delay, odditional roads and structures will bocome doficient, and theso inadequaci.os rust be corrected as they aco crue if the antire syster is to be edequate at the end of the program period. Figure 59 show the location of these additional needs that will accrue over a poriod of 15 gears and Table 11 indicates the typo of needed improvements thet will accrue. Pable 12 shows how the noeded inaprovements which accrue during the 15 cyear period aro to be corrected.

\section{Urban Stato Hi ghways}

The solution to problens of htghway transportation in urban araas must bo bold and dectsive. Problems in those aroas aro critical; 


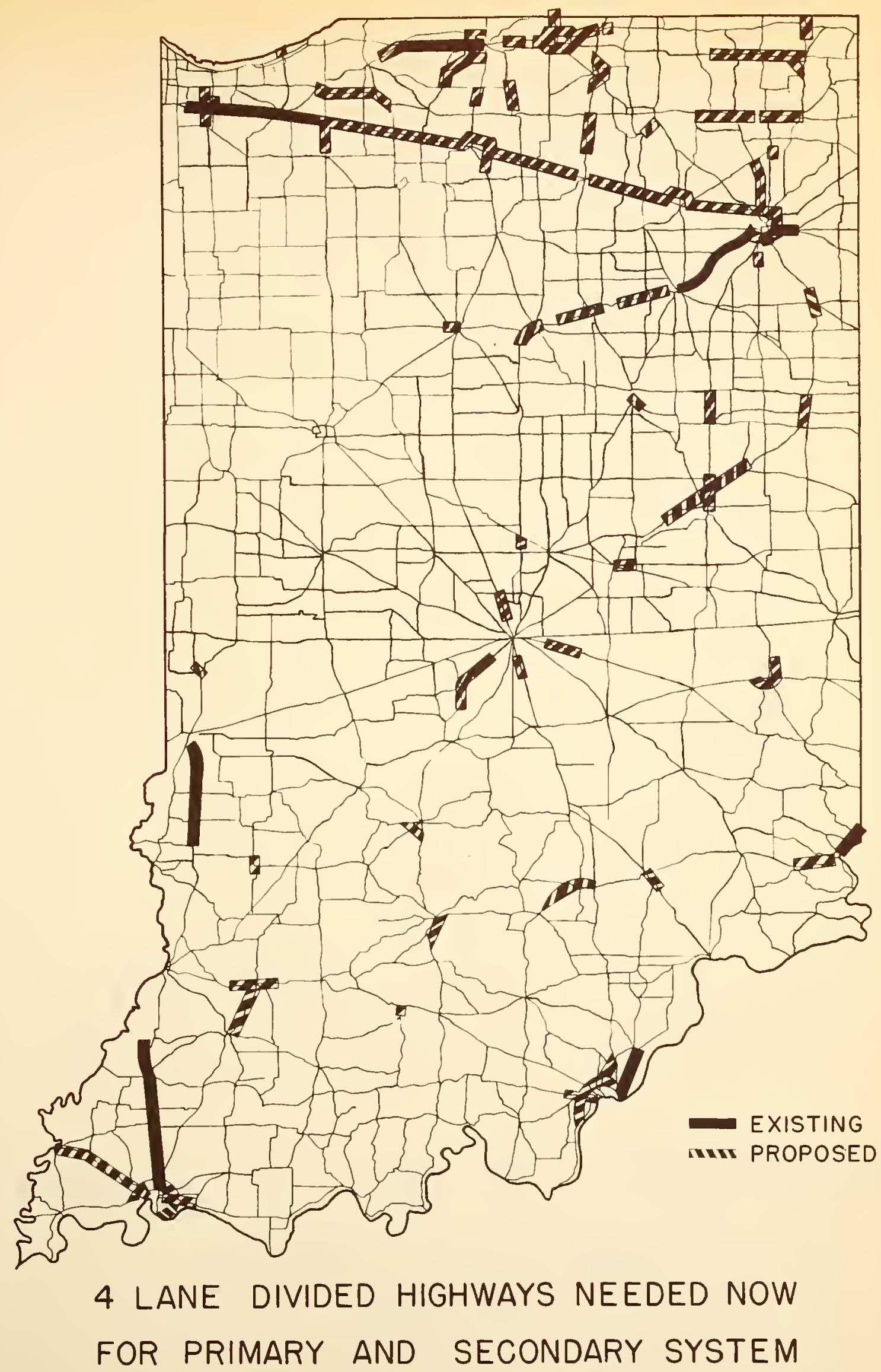

FIGURE 58 


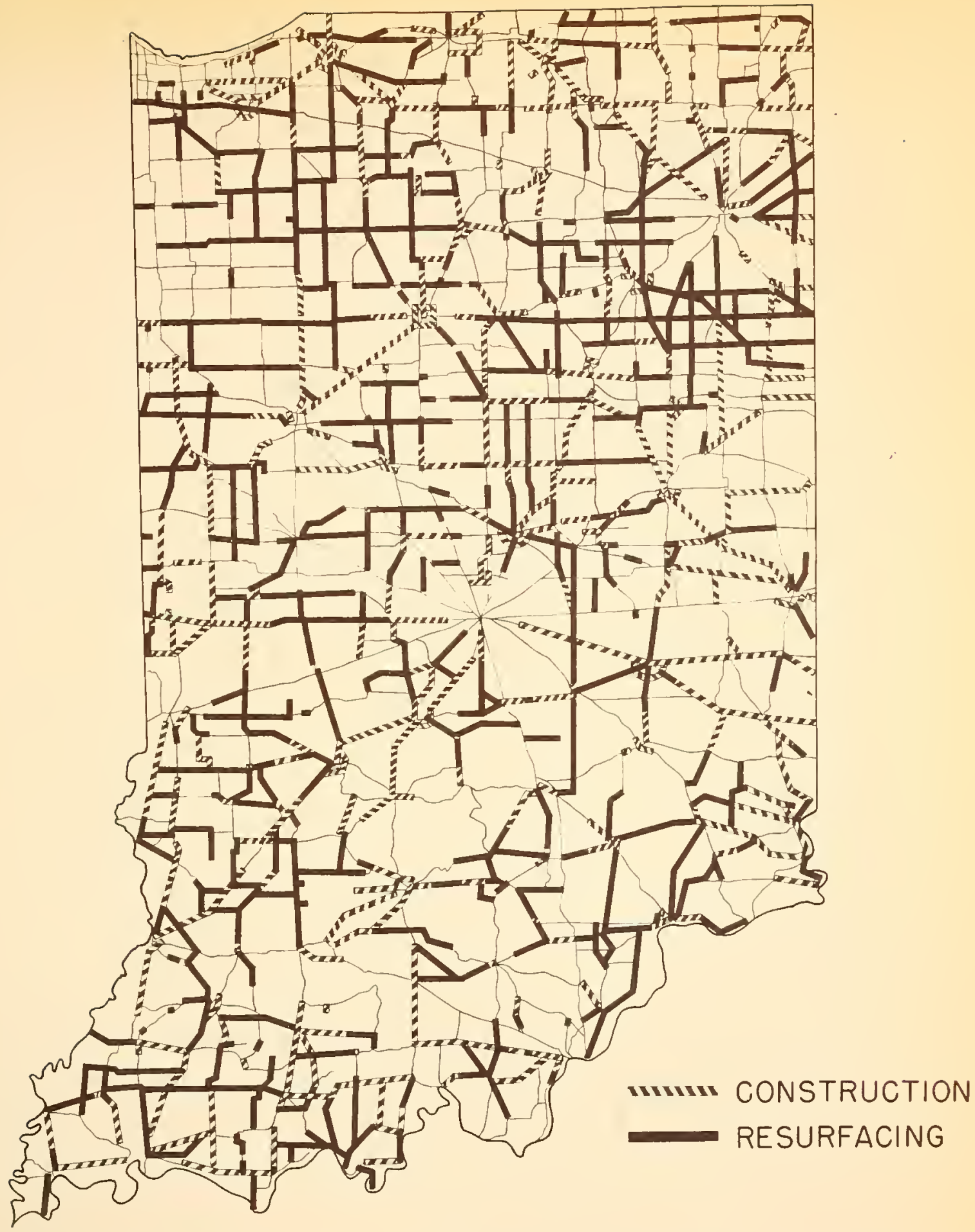

FUTURE NEEDS ON THE INDIANA

$$
\text { STATE } \text { FIGURE } 59
$$


TABIE 11

Futuie Deficiancios on Rral State Highway for a IS-IeEs Program

Typs of Defictencr

Capacity

Structura?

Capacity and Stracturai

Tota1
III 1 e.

604

4,965

$5 ! 2$

6,111
Percent

10

81

$-2$

100

* Doos not Include Interstate Syaten 
Typos o: Fulure Conshrugtion hioedad and Costs on Fure I. Stete Hs phravg Por a 35 yagr Propran *

Type of Imp: Gerents

WLdering and Kิ? surge

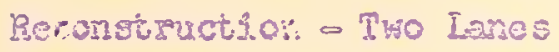

Reconstruction of Four Iraners

Structures (Numbsr 1023)

TotaI
$\$ 9.205$

$$
3_{5} 600
$$$$
1.379
$$$$
1.132
$$

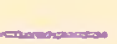

6,217
Cort - H H Hions 198

240

292

118

8

* Doos not include Intergtaie System 
congestion and delay are clogghing the Iifelfnes of each large city. In tho state。 The urban tranaportation problem is not confined to the uro ban extensions of the state systems in Large cities; it also concerns urban extensions and bypassas in other cormuntties. For this study, many of the state routes passing through comnunities having less then 5,000 population have been classifiea as urban routea.

Orer 350 miles of bypasses now aecod require raliti-lano dividad construction. The most criticel unban problens, houever, are in the large metropolitan areasn The work necssary to eliminato those defio ciencies is 1mportant because these streets sorve the hearleat trafic volumes, and the construction costs are extremeit higho whe dense dave elopwent, the high cosis of mightoof=wry, and the urgent sroed for exteno sive froeway construction realt in sverage costa per mile which are neny times higher than the cost per mile in mral areaso

Table 13 indicates the number of miles of urban construction that are present.ly aeeded and the cost ce these inprovements. The cost estimated in this table include the cost of freevay construction in soveral major citles. Those projocts have bsan proposed for severel years and are urgently needed. The $150 \mathrm{miles}$ of bypasees are required to relieve uroan congestion and provide for the through morerent of traffic。

\section{Tyes of Deflciencies and lozk Requi zed}

The trypes of deficiencies now present on the Urben State Highwy Sygtem are shom in table 40 Many miles of the structural inadequacy are pavements whose service life has boen exceeded and are in nsed of reconstruction. Such items as nerrous pavenont, unrestrictod parking, and heavy trafflc volumo aro causing rrany capacity deficiencies。 


\section{Presont DePicioncies ari Coses of Inprovements}

Oa Urober Stito Highraye *

\begin{tabular}{|c|c|c|c|c|}
\hline Ifem & $\begin{array}{l}\text { Y0501 } \\
14108\end{array}$ & $\begin{array}{c}\text { files } \\
\text { Deficient } \\
\text { es } \\
\text { Nesciss }\end{array}$ & $\begin{array}{l}\text { Pumbar of } \\
\text { Deficient } \\
\text { or Nreded } \\
\text { Structures }\end{array}$ & 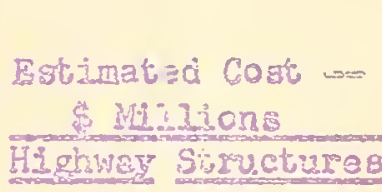 \\
\hline 3895 & 150 & 150 & 174 & $3 I$ \\
\hline
\end{tabular}

Othar Usbar Stata

Highways:

Cities: Popritao tios: $0=3500$

Cities: Populam tion $3,500 \rightarrow$ 500,000

Total
95

20

36

16

6

$217 \quad 327$

$4.55 \quad 357$

322

112

25

29

336

66

Hoes not include Interetat systes: 
TABIE 1

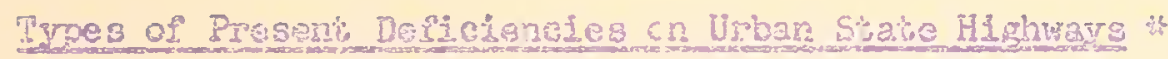

\section{Typo of Daficiency}

Capacity

Structural

Capacity and Stractelusel

Total
Mfis 3

$37 \%$

239

46

$35 \%$
Parcont $02^{2}$

Deficient Hif.

48

39

33

200

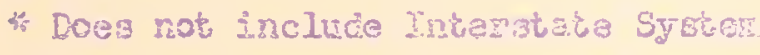




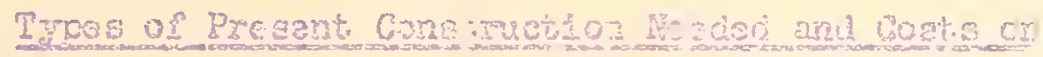
Ui:ban isabo Highese is

\begin{tabular}{|c|c|c|c|}
\hline Trps of Improvemert & 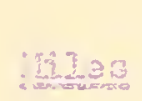 & Cost - M MIJOEE & $\begin{array}{l}\text { Esten: of } \\
\text { Potal cost }\end{array}$ \\
\hline Reswreging & $32: \div$ & 23 & 12 \\
\hline Pecongtruerion & 21 & $b$ & 3 \\
\hline Ner Constructzon & 212 & .08 & 53 \\
\hline Structurgs (Hasbas 322) & $\underset{\infty}{\infty}$ & 65 & $=2$ \\
\hline Total. & 357 & 202 & 200 \\
\hline
\end{tabular}

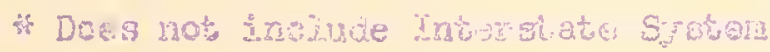


Tho finsncial denand thown ir tabio 15 do not incluce tro cost of

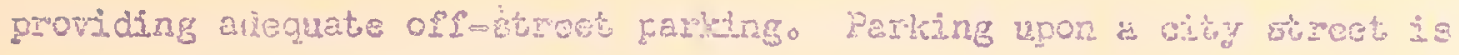

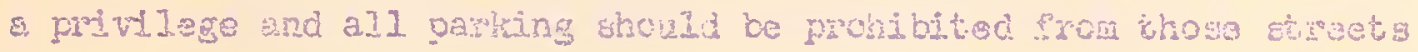
which do not bave alocrats capacity if proking is pemititedo In obiser

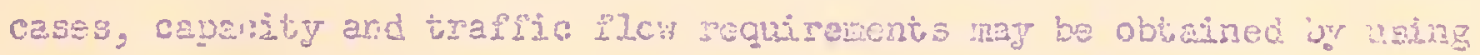

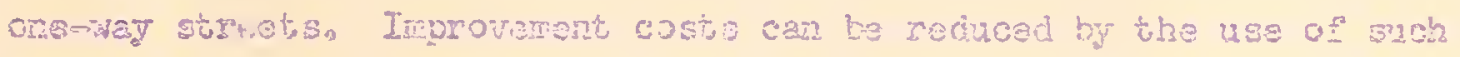

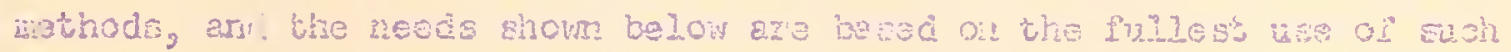

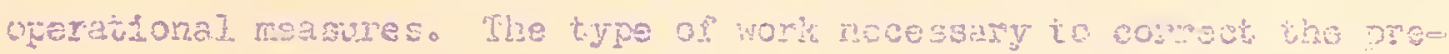
serit defichencies is a so shom in Table 350

Reconstruction, as usad in 3201035 gefers to worls required to

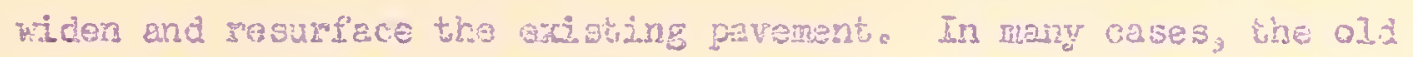

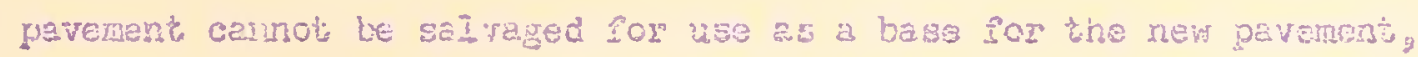
but must be romoved so that the ridered stroet can fit into aldewali gradag and fofogrepto Rekrofacing referg to projects which can be

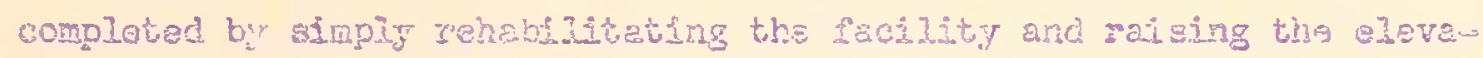

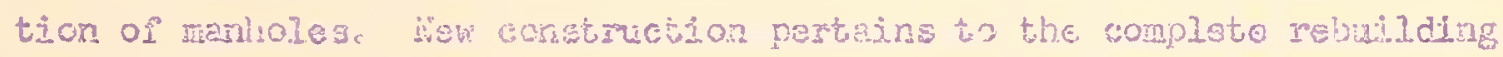

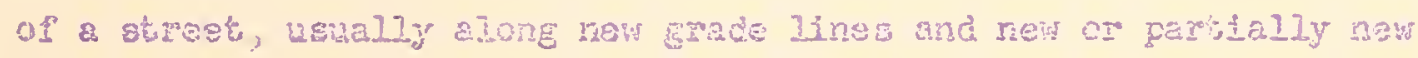
aligniento

\section{Deficiencies Aesring in 25 Yeers}

Toble It anows the coms of the future improvements noeded within 15 jears) fur the liman state Hagriegs and also the kinds oi deficiencies

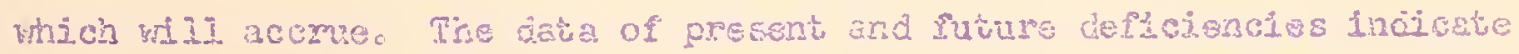
that about a porcent of the sctal cost of urban hightay improvenents

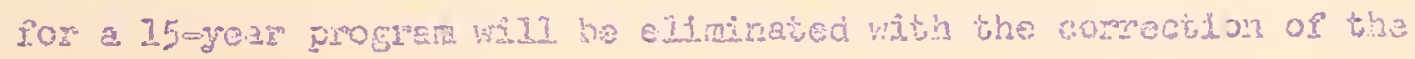

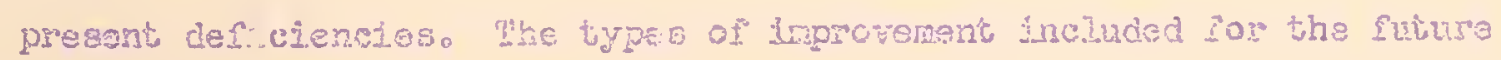
Sor" \& 15-yasr pariod are shown in Tiblo 270 


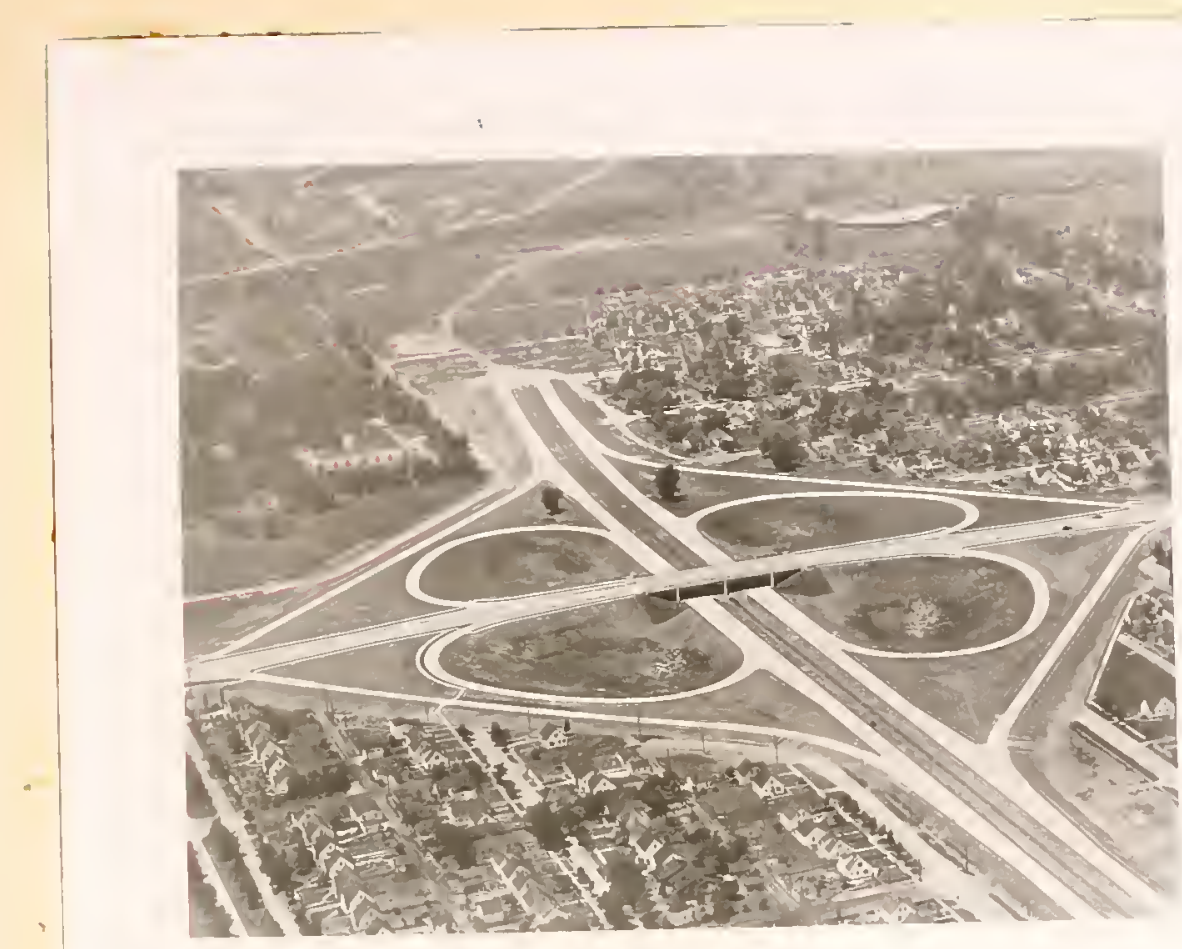

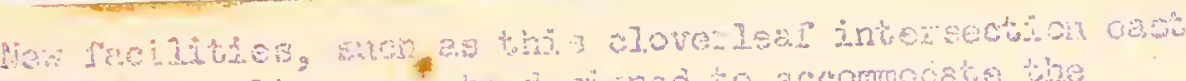

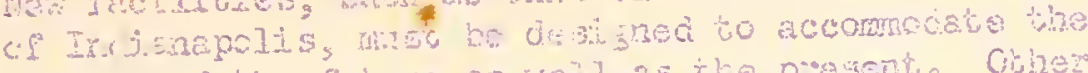

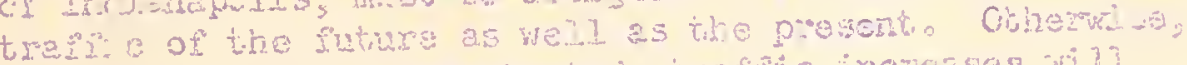

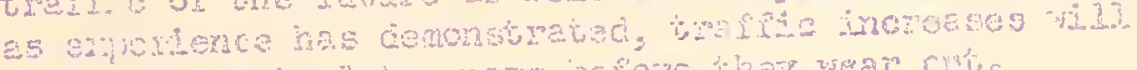

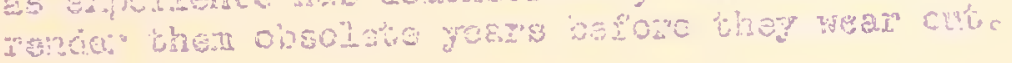




$$
=257=
$$

TABIE I6

Puture Deficiencies and Cosis on Urban State Hi ghways for a 150 lear Frogram

\begin{tabular}{|c|c|c|c|}
\hline Type of Deficiency & 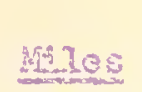 & $\operatorname{Cosi}-\sin 2710 \mathrm{~s}$ & $\begin{array}{l}\text { Yercent } \\
\text { Total Cost }\end{array}$ \\
\hline Copecity & 270 & 3.52 & 56 \\
\hline Structural & 330 & 88 & 32 \\
\hline $\begin{array}{l}\text { Capacity and } \\
\text { Structura I }\end{array}$ & 70 & 39 & 12 \\
\hline Tetal & 670 & 272 & 100 \\
\hline
\end{tabular}


TABIE 17

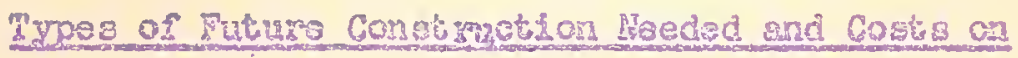

Urban State H Hinwys Por a 15 -Year Progxam

\begin{tabular}{|c|c|c|c|}
\hline Type of Improvement & Igi298 & Cosi - & $\begin{array}{l}\text { Parcent o? } \\
\text { Tosal Co: }\end{array}$ \\
\hline 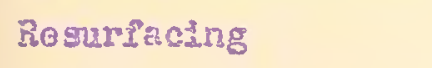 & 315 & 23 & 8 \\
\hline Reconstruction & 202 & 19 & 7 \\
\hline New Construction & 253 & 115 & 43 \\
\hline Susructures & $-\infty$ & 135 & 42 \\
\hline Total & 670 & 272 & 100 \\
\hline
\end{tabular}

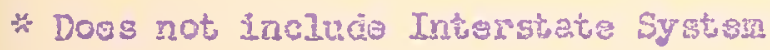




\section{Municipel Sireets}

The Improvements needad on city streets other than on urban extensions to state highways were also investigated. To obtain the total cost for oliminating a.l deficiencies in a given eity, it is necessary to add the cost for nesded runiclpal streets to the cost for the Urban State Highways In that city。

In many of the aljar citias the Urban State Highway extonsions represent the only esiablished systoms oi streets. Tharefore, the arterial and access street mileages discusaad here are thoge estimated during the course of the study by enalyating the street systems of meny cities of Indiana

The uso of proper trafic engineering techniques was assumed in order to reaifo full and efficient urillzation of the streets. In many cases on heavily traveled clty arterials, it wlll be necessary to prohibit parking and to provids offogreet parking to obtaln the necessary traffic eapacity。

\section{Improvoments Roquired on tho Arterial Streets}

Table 18 anows the deficiont mileage of cify arteria]. stroots. The coots are based primarliy on the monies required to eliminate deffeiencies determined from engineering studies of varfous cities in Indiana and from the average urbar inadequacies determined by needs studios in other states. Some of the deficiencies were caused by reasons other than 1nadequate capacity and poor structural condition. For exo emplo, sane arterlal etreete do not have propor drainage, curbs and gutters, and/or dewalks。 
Preggat Dericient Mileage and Costs on Arterial Streots *

$\begin{array}{lr}\text { Total Miles } & 2,624 \\ \text { Miles Deficient } & 656 \\ \text { Percent Deficient } & 26 \\ \text { Deficient Stmctures (Porcent) } & 25 \\ \text { Estimatsd Cost - \$ Millions: } & \\ \text { Streets } & 115 \\ \text { Structures } & 1,7 \\ \text { Total } & 162\end{array}$

* Does not include Urban State Haghways

TABLE 19

Types of Fresent Daficiencies on Arterial Streets *

Type of Deflaiency Miles Porcent of Deflctent Mileage

Capac1ty $\quad 276 \quad 42$

Structurel $321 \quad 49$

Capacity and Structural 59

Total $\quad 656 \quad 100$

* Doss not Include Urban State Highwaya

TABLE 20

Typas of Procent Construction Needed and Cosis on Arterial Streots *

Troe of Improvement Miles Cosi in Mlilions Percent Cost

Resurfacing

Reconstruction and

Hew Construction

Struetures

Total
466

190

$=$

656
2

1

113

47

162100

* Dooe not Include Urban State Highways 
Tai2lo 19 shows the approxinate distribution of the types of prosent deficiencies. The types of Lmprovenent necossary to overcome these dus ficiencies and the cost of correcting them are show in Teble 20.

\section{Fuise Deficiencies}

Tro mileago of arivial streote which will probably become deflciont within the next 15 years is chown in Table 22. The costs that aro indio eated include the cost of structuros. Maximu uss of operational improve monts was assuned in prolonging the ussful life of exs.sting stroets. Mlixs:= mun salvage value of existing city streets was also ascumsd when thess streets are to be improvedo 'fablo 22 gives a cummary of the estimated fork by typo of improvament needed to elzminate tho deficiency.

\section{Rosidential Streets}

Kiang miles of residentiol sirests do not have curbs and gutterg nor adequate drainage and sidewuliss. However, in nost cases, these deficiencies have not been considered as a direct highway need because the abutting property owners are usually responsible for the type of street in front of their homes. In addition, many cities requise that the land devaloper build streets and sidewalks to at least minimum acceptable standards before selling lots to prospective home ownexs. Usually these city अandards require streets with propsr surface, curbs and gutters, sidewalke, and storn sewers. The costs presented here are those required to maintain and Improve for the next 15 years residential streets that have been initially Iraproved to acceptable standarda by the property owners or the land developer.

Tabie 23 indicates the magnitude of some of the deficiencies that are present or that will accrue during the next 15 yearso Cost of 
TABLE 2I

Trpes of Future Dericiencies and Costs on Arterial Streets

\begin{tabular}{|c|c|c|c|}
\hline Type of Deficiency & Mlos & Cost - M Miltons & $\begin{array}{l}\text { Percent of } \\
\text { Total cost }\end{array}$ \\
\hline Capacity & 117 & 24 & 32 \\
\hline Structural & 176 & 38 & 50 \\
\hline Capacity and Structural & 22 & 13 & 18 \\
\hline Total & 315 & 75 & 100 \\
\hline
\end{tabular}

* Does not include Urban Stato Highrays

Types of Future Construction Needed on Artertal Streets *

\section{Type of Improvement}

Resurfacing

Reconstruction and New Constzuction

Total
Number of Miles

154

161

315

* Does not include Urban State Highways 
TABLE 23

Prosent and Future Irpprovenents and Costs on Residential Stroets

\section{fype of Injorovent}

Resurfacing

Reconstruction

Total
Miles

2,155

$\underline{2}, 975$

5,130

\section{Cost o Millions}

48

259

207 
structures 18 included in the inprovomerats 1ndicatod. The rato of improvement on residential streets kill vary by commuty because these streets must be improved to a large extent by local funds, including property assessments and othar local sources of revenue.

\section{County Highways}

All roads except gtate highways and city streets are under county Juriadiction in Indiana. Kost of the counties, however, have not estabIished a system of classifying their highways. Therefore, in this study, county highways have been classilied into three groups - Primary, Secondary, and Local Service - and they are treated in this report as estabo Iished systerae ( 7 )。

The greatest need for inprovernent on county highways is on the Primary and Secondary Systems; these highways carry the largest volumes of traffic. Although a great proportion of the county road mileage has 2.11-weather surfaces, many of the structures on these systems are inadequate for modem traffic。 They are neither wide enough nor strong enough. A great many gêructural and functional deficiencies also exist on these county roads.

In Table 24, the mileage and cost of the work required to elininate the present deficiencies and those expected within the next 15 years are shown for the county Primary and Secondary Systems.

Highways in the Local Service System are mainly concerned with provlding adequate transportation for people who abut the highway。 In most cases, all that is required to eliminate deficiencies is to improve 
TABIE 24

Present and Future Improvements and Costs

on County Primary and Secondery Syotems

$\begin{array}{lccc}\text { Type of Improvement } & \text { Mijies } & \text { Cost }-\$ \text { Hilions } & \begin{array}{c}\text { Percent of } \\ \text { Total Cost }\end{array} \\ \text { Resurfacing } & 9,971 & 121 & 32 \\ \text { Reconstruction } & 13,862 & 240 & 64 \\ \text { New Construction } & -477 & -17 & -4 \\ \quad \text { Total } & 24,320 & 372 & 100\end{array}$


and proporiy maintain the ariating roadiay end replace the Inalequate gtimuctures。

Vory littlo major road construction was contemplated on the local road sysitem. Those counties contalning growing urben areas should require that the now roads in saburbs bo developed to adequate standards by the land developer. Those improversnts are not included in total construction costs for local rords gince they axe primarily a responsiblo lity of individugl property owners or land developerso Sone constructions however, is antickpated on this system. It will be the typo of congtruct tion that is required to keep the present system serviceable for the owall volume of traffic that uses these roado. The cost of the present and future work required on the Local Service Syrstem is indicated in Table 25. 
TABLE 25

Frosent and Future Ingrovernents and Costs on County Local Service Systems

\section{Type of Improvement}

Resurx̂acing

Reconstruction

New Construction

Total

\section{Cost - Mi M110ns}

71

87

$-3$

16.1
Percent of Total Cost 44 54

2 100 


\section{Se dection of a Progrars}

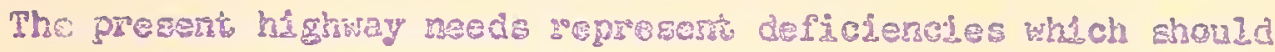

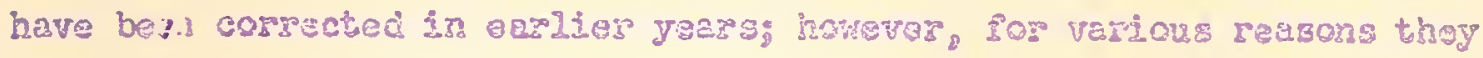

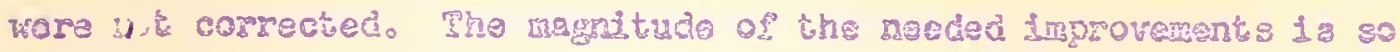

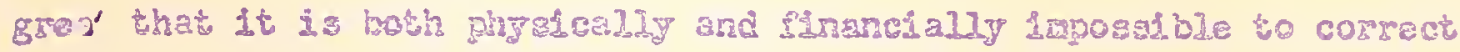

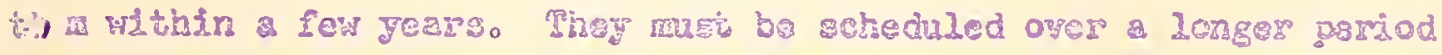

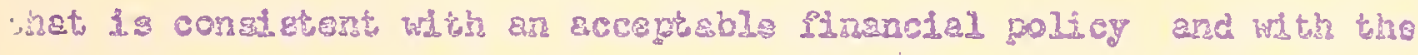
arazlabilfty of angineswing and conctumbion manpowor.

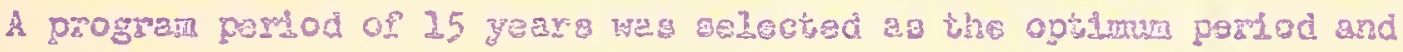

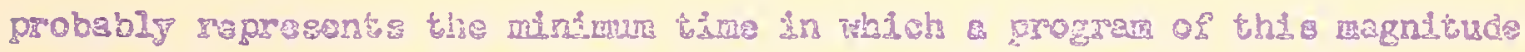

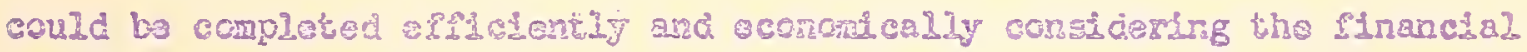

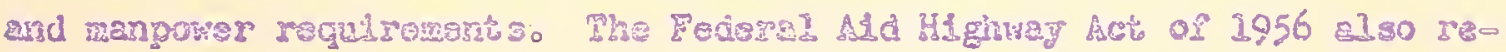
qูaม⿱

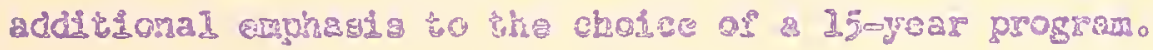

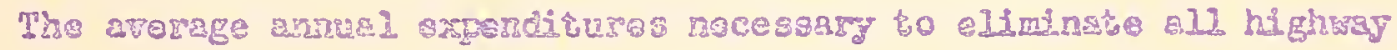

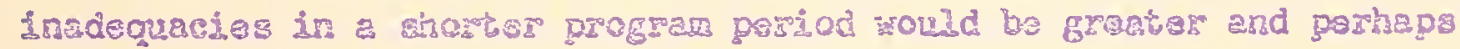
bayono the reverus gapactsy of Indiana. The shortas the progran pertod,

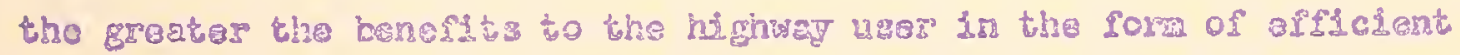
operation of his eutomobile, tine savings, raduced acclents, and othor bonefsts. On the other hard, 2 longer program fersod remite in a maller

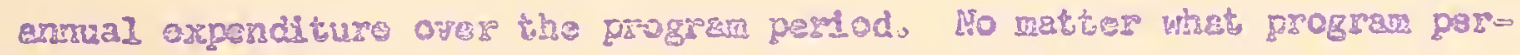

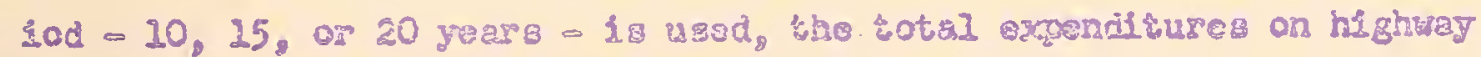

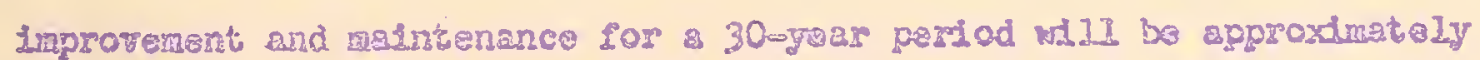
the eame (25). This fact indicates that fros a long rengo visupolnt a 
10-ycar program would not cost mose than a 20-year program and would yloid additional beneritg to the highweg user.

\section{Types of Niseded Irpsorements}

The followng improvements were considered in the devalopment of the costs for a 15-year prograg in this study:

1. Imedicto Improverents Naeded - The present defictencies.

2. Future Bequirenents - The roods that ars now adequete but that ulli wear out whthin the program period. and neod replacement.

3. Replacements Heeded - Improvements necessary before expected Ufo is attained。

4. Stopogsp RequLrements = Improvementg of a terporarg nature to presentiy inadequato roadg to rake thom useable unt1l inadequaclos can bo eliminated.

5. Meintenance - The proasrvation of the inyestment, operational cout 3 , ard hightay housakeeping。

6. Adrainigtration = Errgirseering superviglon and business management。

\section{Iresodiate Inproverents Nsedad}

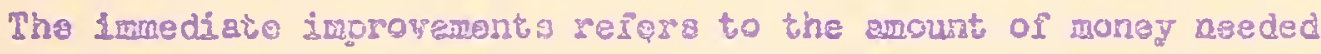
to inprove all inedequate highwy', bridges, and raflroad crosging to tolerable or degign etandards. This term refers explicitly 60 those Inadequactes of the highroy systers of Indiana that have accurulated becsuge of the ever-increasing gap botween an adequate and an inadequato highway aystom. 


\section{Future Regul rements}

Although 70 percent of the mileaje on all systera is inadequato now, many miles of presently adequate highways will become deficlent bafor, completion of the 25 -year program. Roads vear out or become Insiequate, In a capacity sense, due to the increasing volumes of t:affic。 The accrual of these deficiencies during the program poriod represents a Iarge portion of the total costo

\section{Replacements Needed}

Replacenents aro results of inadequacies which develop on improved sections of highway before they are anticipated. For example, although the arerage service Iffo of a structure is 50 years, a few stmetures will be adequate for only 10 years while others may be adequate for 75 years. A new bridge could be destroyed by a 1200 , or a relatively now section of highway may need more traffic lanes because of an unexpected Increase of vehicular travel, perhaps caused by the construction of an Industry along the new highway. The number and cost of such improvements, which will become inadequate within the program period, have been detero mined by probability computations. Over a short period of time replaca. ment costs for a highway system are small, but they increase progressively as the program period is increased. The replacenent costs for the 15-year program for the gtata highway systems are shown in Table 26.

\section{Stop=Cap Requirements}

At an accolerated rate of construction, it : 111 be necessary to delay many improvenont projects for several years because there is a 
TABLE 26

Stop-gap and Roplacement Cost 8 for State Hi ghwey Systems.

\section{5 -Year Program}

Interstate System

Hoplacement

Stopogap

Pura). Primary and Secondary and Urban

Replacement

Stopagap
Cost

(3) $19,004,000$

$95,130,000$

$33,210,000$

$159,880_{8} 000$ 
trenendous backlog of required improvements. Some of thoe日 deleyed in $\rightarrow$ proverents will require tomporady congtruction to permit traffic to safelg use the highwy. This additidonal condiriction is called the stopogap requirements. The cosi of these improvaments wes found to be approximately nthe percent of the totel construction coets on the atate highway aystems the city aroterial gystems, and the ccunty highwy aystems for the 15-yeas program. Stop=gap costs for regidential stregst and local Servics roads wers not conaidered becauss 1mprovemst projects on these syberms could be postponed without uridu hardship to the relatively few highey users. Table 26 Indicates the stopogap cost8 on the state highway gystems for the 15-yoar program.

\section{Naintenance}

Ef fective maintenancs of highwsy faclitiles is agsential so that uninterrupted traffic gargice can be provided. Anelysis of cost records of highway maintsnance is diffleult becense these are mumercus mainten ance functions and many of these functions are not clearly geperated from constinction activitieg。 Waintenence cost 8 , so used in this report for etate, county, and city highway gystersa, do not include the cost of botternonts, anch 8 s the sost of constructs on of lokitypo surfeces and other itoms which aro capital 1mprovements.

State Highway Maintenance

Roadway and structure uBatnisnence on tho rural state highways ghould bo improved。 ht prosento funds fo: proper maintenance of many miles of highway aro dispargad in orcer to spread ayallable funds over the stato gystens. 
Naintenance cost records of the state Highway Department noro ved as a baso for ext1mating the cost of adequate melntenance on the present and future systans. Msintenance costs on the future systar will increase because many arles of four-lene divided highwgy and higho type, two-lane highway will be contructed. The average maintenance costs for vartous classifications are show in teble 27 .

\section{County Road Maintensnco}

Cogt information in the counties of Indiana ie insdequate. How over, costs for adequato malnteriancs vore detemined on the basio of arerage costs for labor, agterisls, and oparating expenses. A aumnary of malnterance cosis used in this study is show In Table 28. Included in these sotimates are sufficient funds for roplacement of gravel, and patching and sealing of bicurinous paversents.

\section{C1ty Street Kajntenance}

C1.ty street cost records Iike county highway cost records, ars not adequate for estimating raintenence costs. The few records kept by certain citios vary considerably and tho absanco of a uniform inathod accounting mekes it difficult to asolgn equitable coetso Unit costs for maintenance were deterinined, howover, from ayailable information for artorlal and Iocal access gtreet systoms and ero shown In Tablo 29.

Adolinistration

Adrinf atrative and ovarhead costs wero included in the amount for maintenance. Among the adrinitutrative costs are charges for rext 
TABLE 27

Estimated Annual Costs Per Mile

for Adequate State Highway Maintenance

Surface Typo

Systern

$\frac{\text { High }}{\text { Inltiple Lane Two-Lane }}$ Low

Interstate

Bural

$\$ 3500$

Urban

4500

Primary

Bural

2200

$\$ 1500$

$\$ 1700$

$\$ 2000$

\section{Secondary}

Rural

2200

1400

1600

1500

Urban

3000

3000

2500

3000 


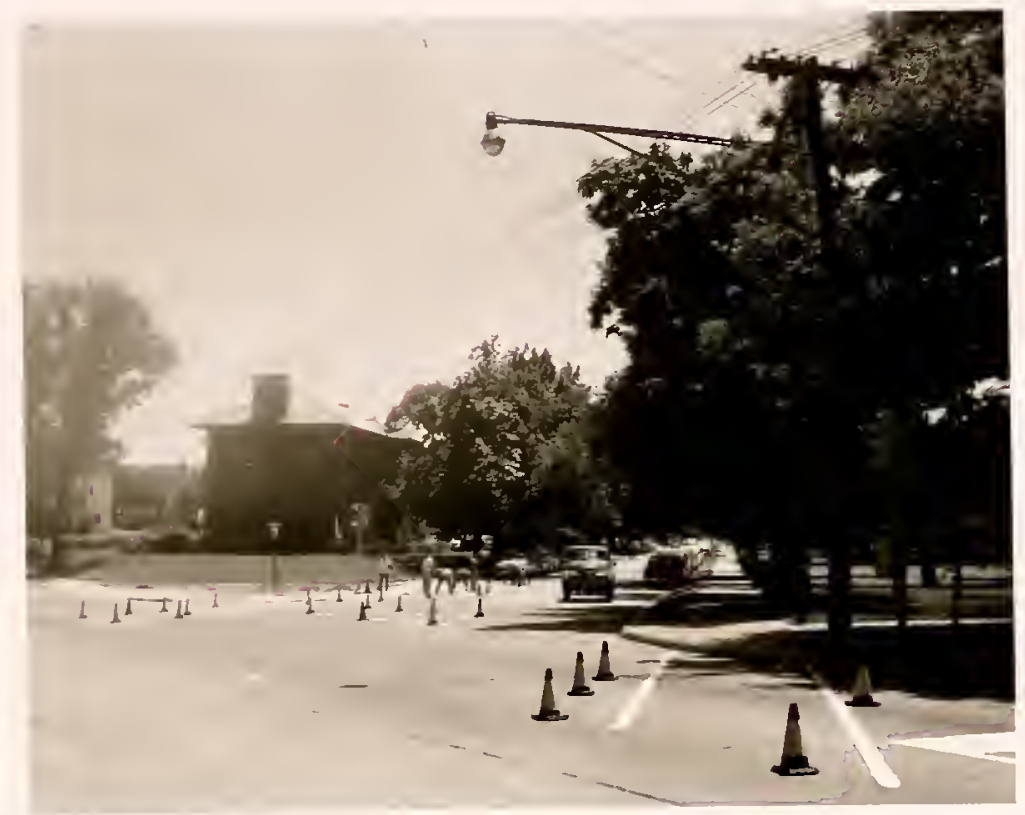

Included in maintensnce is the constant renel:a? of paverent, markings and other operationai aid.

Figure 61 
Estimated Annual Costs Por kifle

For Adequate County Highwsy Maintenanco

\begin{tabular}{lc} 
County Systerd & Dollars \\
\hline Primary & 850 \\
Secondary & 500 \\
Local Service: & \\
Improved & 275 \\
Unimproved & 50
\end{tabular}

TABLE 29

Estimated Annual Costs Per Mile

For Adequate City Street Manienance

System

Doliars

Artorial 2300

Residential. Streets 1060 
and upksep of highway offices; salaries sor adminietrative ataffa, clerks, and typista; costs of plans and blueprint roproduction; and office supplies。

\section{The Program}

The program for this study is presented in the form of average annual costs and total costs for a 15-year progrean. Programs for other periods of time were considered but will not be presented for ressons already explained. The progras prosented shows the distzibution of costs according to the classification of tho atsio, county, and city highray systems。

Because of the large backlog of needed improvement a, a large por = t1on of the program tim will bo spant in correcting these deficlencies. Any future inadequacies which develop during this tine, of ccurso, must bo delayod until the backlog of deficiencies ase corrected. It may also be desirable to select different programs for differmb systems, such as an accelerated program on the mejor eygtems. However, worthy of consideration is the fact thet longer program pertods on any syatem post pone for many yoars improvements badly seeded nowo

\section{Stsate Highway Progran}

The annual progran costs for the rural and urban state highways are sumarized in Table 30. In this and the following tables, costis of stop=geps and replacements are includod in the cost of future improverant3. Adrinigtrative costs are included In the maintenance costs。 In the progren outlined, 48 percent of the total cost is required to corract exdating deificiencles, 39 percent is to provido for needs that will eccrue within 15 years, and 13 percent is for maintenance。 
Cost of a 25 lear Program on the State Highway Sybiems

\section{Typer of Highwgy}

Rural Interstate Highway ${ }^{*}$

Erigting Needs

Future Bloeds

MaIntenance Needs

Sub Total (Rural Interstate)
Total Cost

Average Ansual Cost

\section{Urban Interstate Highways *}

Exi sting Needis

Future Needs

Maintenance Nseds

Sub Total (Uivbas Intexatate)

Total Interstace (Rural and Urban)
\$ $274,483,000$

$58,754,000$

$26,570.000$

$359,807,000$

$\$ 1,271,156,000$
अ $18,299,000$

$3,917,0000$

$1.771,000$

(3) $23,987,000$

每 $84,74,3,000$

\section{Pural State Highvays (Primary and Secondary)}

Exd bsing Needs

Future Needs

MaIntenance Needs

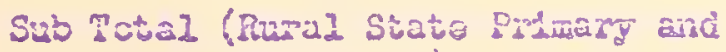
Secondasty
$471,888,000$ $984,991,000$ $289.706,000$

$\$ 1,746,585,000$ $\dot{8}$

$31,459,000$ $65,666,000$ $19,314,000$

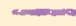

4. $116,439,000$

\section{Urban State Highways}

\section{Existing Neodo}

Future Neede

Mafintenenco Hesds

Sub Total (Urian)

Total (Rural PrJmary and Secondary Usban)

Total Intorgtate and State Higtway (Rural and Urban)
(5) $201,642,000$ $327,736,000$

$64,882,000$

$\$ 594,267,000$

$\$ 2,340,852,000$

\$. 156,056,000

$\$ 3,612,008,000 \div 240,799,000$

* Costs reviled to valuss obrained from Section 108(d) Study conducted by SHDI。 


\section{County Road Progray}

Improvement and maintenence of the 76,000 miles of county lighmays to acceptablo standardo will cost $\$ 66$ million por year for 15 roars. Heeds, of course, are not unformit dstributed throughout the atata. Heavily poprlated countios whth extenslvo rosd nileagos near urban aress have greatas noeds than thos countios of a prodoninatoly rural nature. Tablo 31 aumarizes the costs of a 250yoar linproverent progran on the county gysteris.

Of the total cost for tho 15 oyoar program, 54 parcent 1 w for cono struction and 46 porcens is for mainionance. When compared with the State Highway Syetom costs, tho percontage required for maintenance 1 a much higher on the county oystem. This is tyue bocauso rnost of the mileage on the county gyatera has an unstabilized surface and roquires proper porlodic maintonence to be kept in an adequate condition.

\section{City Street Frogram.}

Beaed on the axtertal syston selected for those cities which did not have clessified strot systers and aleo on the clasaifled gtreet systems in existerce in a fow of tho largor citieg, tho coses for a 15-year atret improveraent program choan In Table 32 vore obtainedo Hong of tha cost for arterial streto in citiea are State HIghwy Syriem costs and aro not included in this table. In some caaso, portions of the suta Hifhway S7gtom should be ramoved from the endler cjtjes by mene op adequate bypaseos end the present otrests should bocone the respongibility of the cities larolvod. 
toxpe of Highwey

Primary and Secondary Systems

Existing Nasds

Future Needs

Mainienance Needa

Sub Total (Primary and Secondary)
Total Cost Annual Cost

\section{Local Serrice System}

Existing Needs

Future Heeds

Maintenance Needs

Sub Toial. (Local. Service Roads.

TotaI
$\$ 105,001,000 \div 7,000,000$ $56,493,000 \quad 3,766,000$ $222,786,000 \quad 14,852,000$

$\because 384,280,000 \quad 25,618,000$

(1) $990,790,000$ i $66,052,000$ 
Cost of a 25 year Program on the City Street Systems

\section{Type of Highway}

Arterial Streets

Exs.sting Needs

Euture Neods

Maintenance Needs

Sub Total (Arterial Streets)
Total Cost

Averaze

Armuel Cost si $10,788,000$ $5,003,000$ $5,984,000$ * $21,775,000$

\section{Residential Streets}

Existing Needs

Future Needs

Maintenance Ifeeds

Sub Total (Residential Streets)

Total (Arterial and Residential)

\begin{tabular}{|c|c|}
\hline $\begin{array}{r}109,740,000 \\
97,080,000 \\
116,490,000 \\
\end{array}$ & $\begin{array}{r}7,316,000 \\
6,472,000 \\
7.766,000 \\
\end{array}$ \\
\hline $323,310,000$ & $\$ 21,554$ \\
\hline 935. & 43 \\
\hline
\end{tabular}


MILLION

DOLLARS

PER YEAR

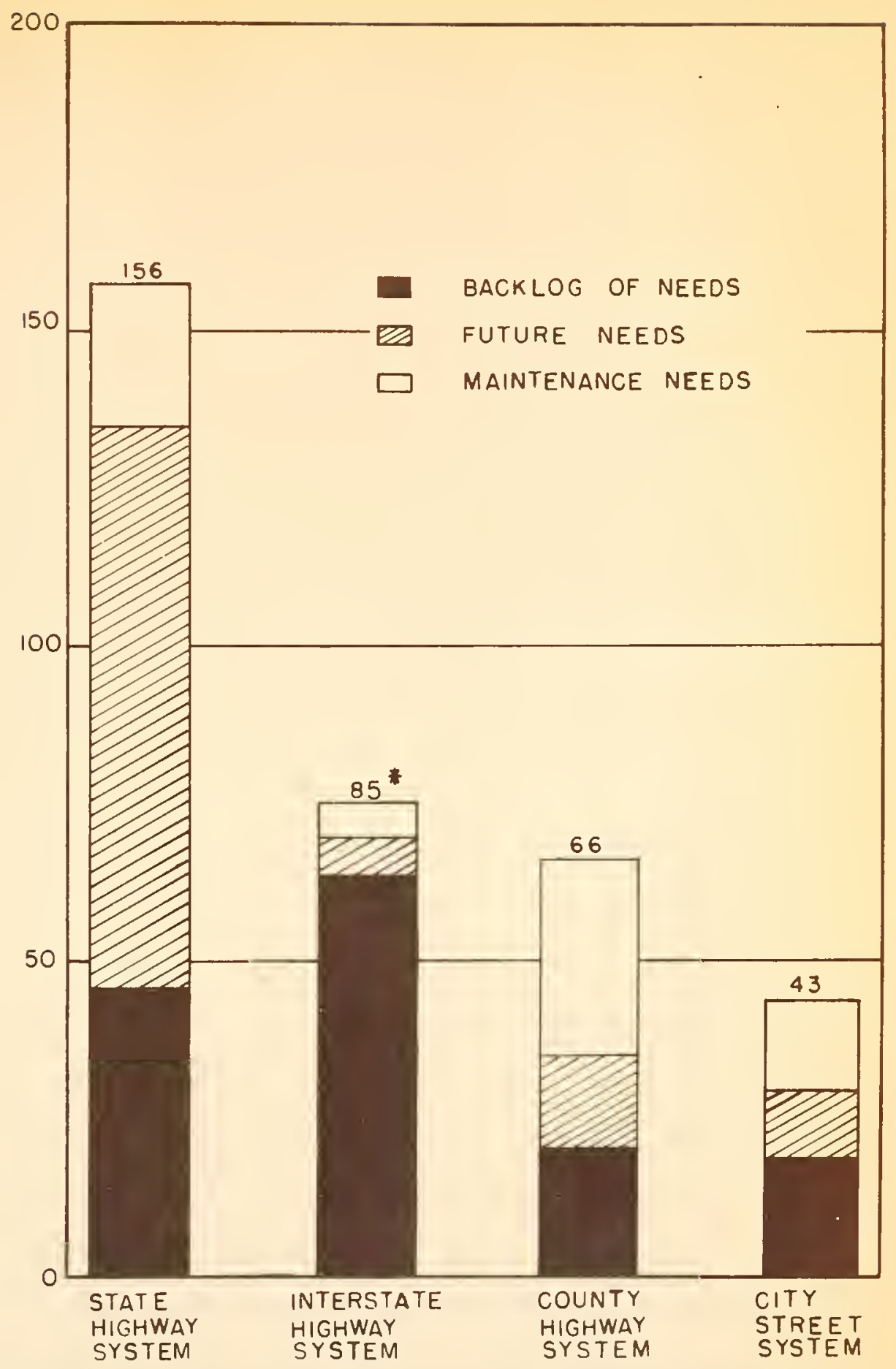

ANNUAL AVERAGE COST FOR 15 YEAR PROGRAM

* corrected to costs obtained from section $108(0)$ study 


\section{Rasultis of a 15-Yoar Program}

\section{State Syatemg}

It wss essumed in this otudy that the daficiensies of each highos way system (state, county, and clty) would be corrected to a level that would give adequate service, coneidering tho classification of sach road or street and the arount of traffic undeb uses $1 t$, by the ond of a 25-year improvement progran. The gtatus of the Intergtate System would be as ahown in Table 33 .

It should be noted that on the rural system meny miles of four lane divided highways are necessary to complete this progrem. All mural mileage of the Intergtate System must be at least follane divided construction and Innted accsss. For economic reasons it will bo necessary to robuild this entire systen except those perts included Ix the Indiana Toll Road and the exieting portion of the Triestato Expressway。

The change in status on the rural Primary and Secondary Highway Syatens for a 15-year program is given in Table 340 The degreo of improvement on this gyster is obvious. The number of miles of peved two-lane highwage will be decreased from 85 percent to 72 percent of the mileage in the two gystems, and the number of miles of four=lene divided highway will be increased from a percent to 18 parcent. Beo cause much of the maral motor vehicle travel will occur on these system. beneflte to highway users will be great.

It is estimated that the number of miles of bypasses around urban areas will ba increased by orer 200 mileg. Many milea of Urban State Highway extensions will also be widenod, resurfacod, or rebuilto The lexger urban areas throughout the state wili have Ireoway gystems 


\section{Fresent and Future Stacus of the Interstate Sjotem}

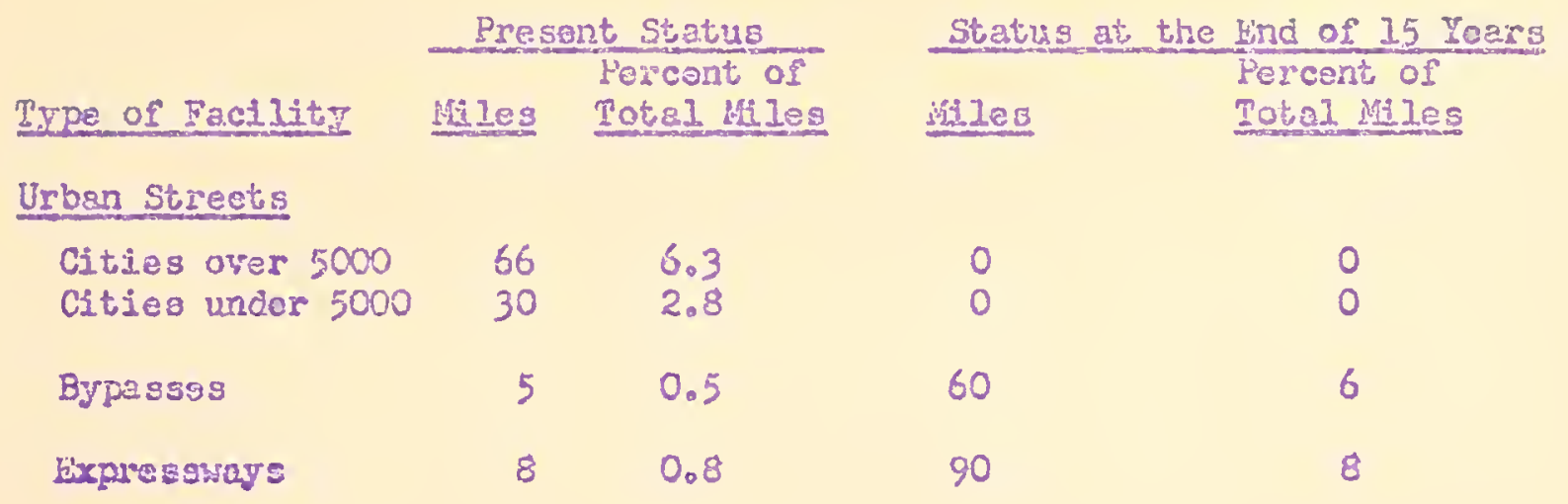

Fưral

\begin{tabular}{|c|c|c|c|c|}
\hline Paved Twoolane & 700 & 66.6 & 0 & 0 \\
\hline Faved Fourentano & 242 & 23.0 & 950 & 86 \\
\hline Total. & 1,051 & 100.0 & 1,200 & 100 \\
\hline
\end{tabular}


Present and Future Status of the State

\section{Bural Primary and Secondary Srstems}

\begin{tabular}{|c|c|c|c|c|}
\hline & \multicolumn{2}{|c|}{ Present Status } & \multicolumn{2}{|c|}{ Statug at End of 15 - Iear Progran } \\
\hline Type of Facility & Mije & $\begin{array}{l}\text { Percent of } \\
\text { Total jalles }\end{array}$ & MiIes & $\begin{array}{l}\text { Percent of } \\
\text { Total ifiles }\end{array}$ \\
\hline Gravel & 65 & 1 & 0 & 0 \\
\hline $\begin{array}{l}\text { Intermediato } \\
\text { Favement }\end{array}$ & 935 & 10 & 935 & 10 \\
\hline Paved tho-Lane & 7,820 & 85 & 6,965 & 72 \\
\hline Peyed Fourolano & 390 & -4 & 1,200 & 28 \\
\hline Total & 9,200 & 100 & 9,600 & 100 \\
\hline
\end{tabular}


s

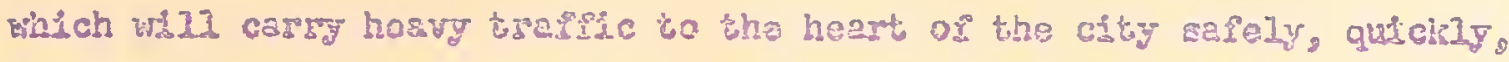

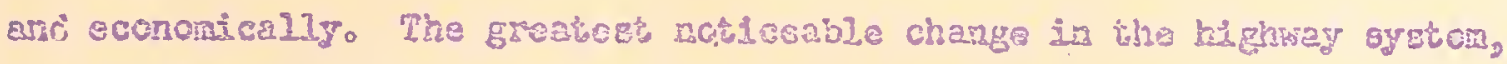

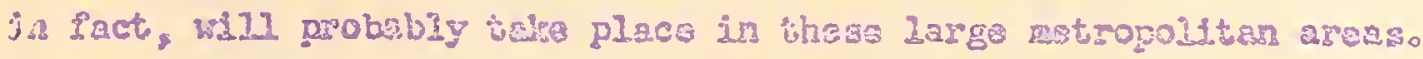

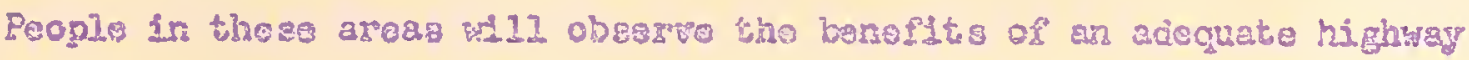
23 thoy drive to work, alrop, attond church, and parform other daily

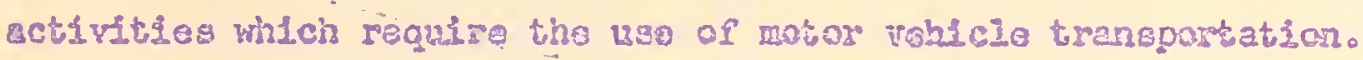

\section{Count Hi Hivey Sygiser}

A great pertion of tho Prangy and Secondery Systems ton the

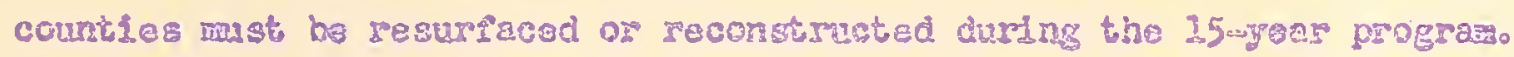

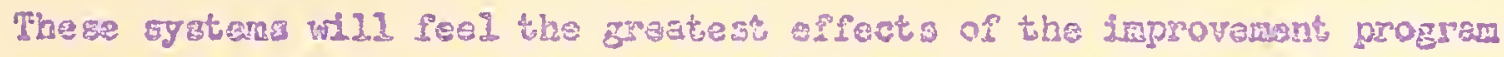

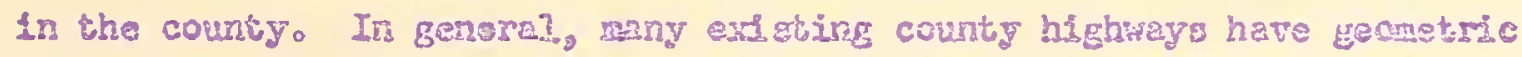

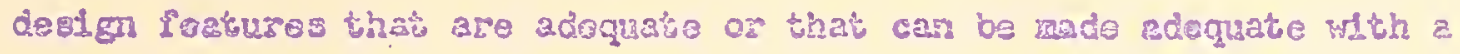

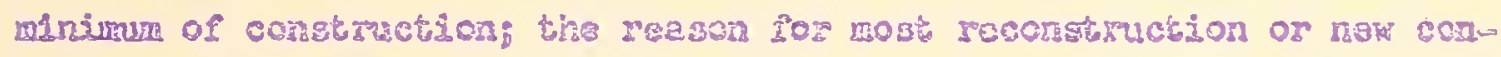

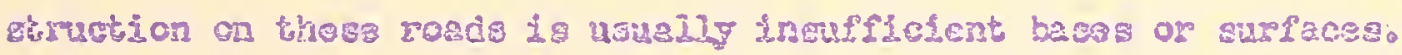

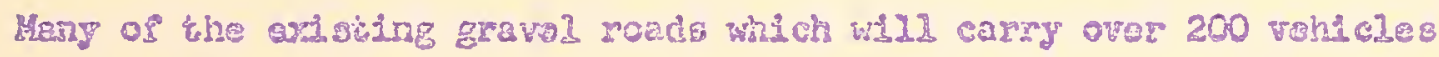

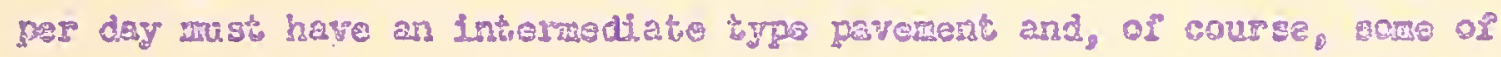

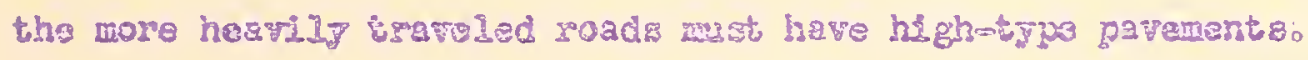

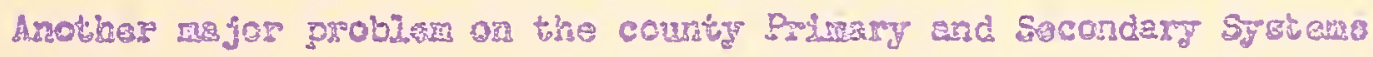

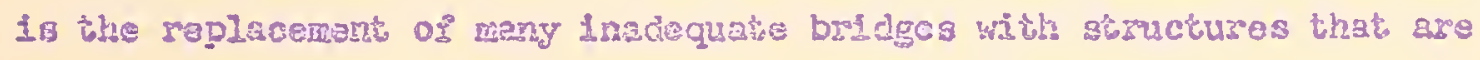

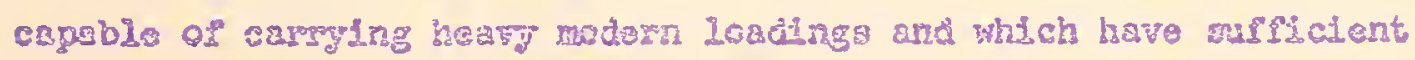

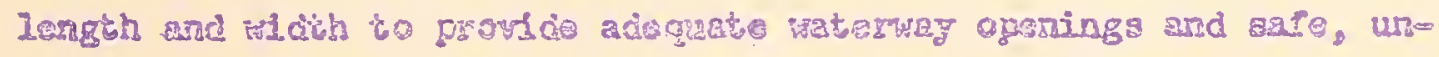

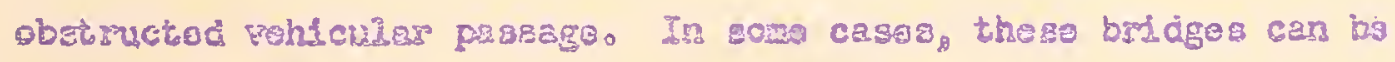

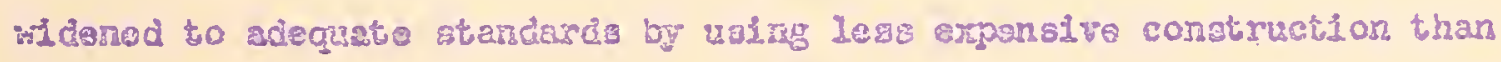
hould be requited for compieto zeplacersat.

The Local Service system will rensin ossentially ac it is today except for replacomsnt of insdequato structures and rebuilding of Ln adsquete roado. shost of tho monoy that vill be epent on this sgatem 


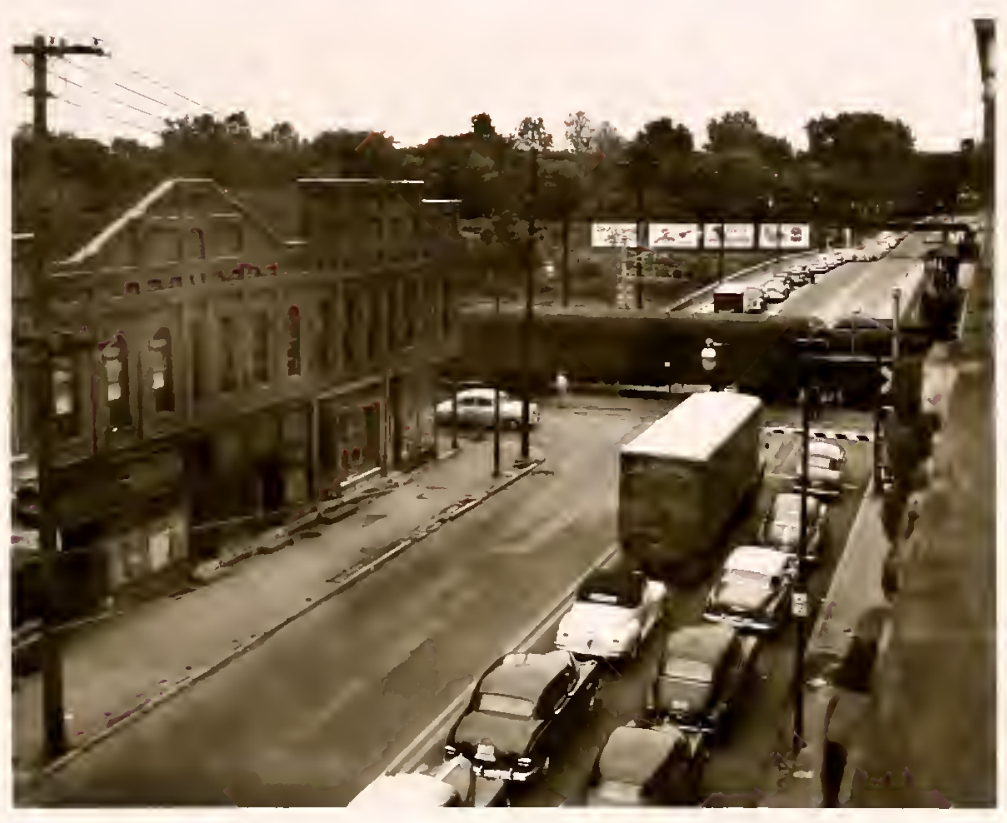

Botilenecki causing lengthy delay mut bo elininatod or by passado 
wll be wsd for adequate maintenance. In general, the lowest surfac? type should be gravel, crushed stone, or some stabilized road sur'ace. In countses in which large urban areas are located, the prow ilem of the Local Service Syeten will be complicated by the continual expension of the city suburos into the rurel areas. These now highways will provide an additional maintenanco and cost probien to the counties.

\section{City Street Systen}

Tho large citios of the stato are fuced with a serious problem in the elfmination of present and future deficiencies within the noxt 15 years. Freewey and major thoroughfare construction is necossary or some city arterials in addition to the proposed for the State Highway Syeted. A 1954 comprohengive traffic survey roport for the city of Indianapolis out Ines an extensive improvenent program on the artarial systen of the city which would greatly benerit the highway usex。 IhIs progran would bo accomplisined by providing sireets of adequate wadth and surface for the movenent of traffic with a minimum of delago In the amgllar cities wuch of the city arterial syster is provided by the State Syator. For thia reason the smaller citles do not have the astm joue problems that ere found in large cities. However, these cities do have problems on their arteriais, and a laxge amount of improvement is still necessarty

Beceuse the initial construction of new residential streets is the responsibilfty of the land deteloper, the construction standards for thear streets depend upon local laws and regulations concerning platîng and city planning. In many cities these standards are adequate and enco forced. When the improvernent program ends, these new streets and all 
existing streets sirould bave adjquato surfaces, curbs and gutters, sidewalks, and drainege. Tirege streots will then provide adequate service for reaidential traffic and also contribute to a wellodeveloped neighborhood that a wholesome saciety neediso

Tho parking probiem in most cities is bsconing more serlovs each Zeas and there is 1 tuth Indication of any relief unless bold and dacioive ection is takerso Although parking improverents have not boan included in this report, adequate, off-atreet parking garages and lots should be constructed 1 in the next 15 jears to more fully solve the highwey transporicion croblem. Texminal parking facillties must be developec at the same rate or perhaps even faster than highway improve ments. The urban tiansportation problem will be only partially solved if the problem of adequate parking is lgnored or a half hearted solu:= tion 18 attempitecio

\section{Priorities}

The anount and cost of the work required on the roads and streets of Indena raike it imperative that priorities of improvemant bo deter mined and followed in the deveicpmert of highway facilities. This tool. of planning will insure that the rost urgent and jmportant work will be completed as rapldzy as possible and will place the entire program on a logical and systematic basis.

The fact that roeds and streets are classified into different sy. stens places highrays on some degree of priorityo In most lnstances a highway on the Interstete System nould have more urgent need of Improvement than a county road. Each systen, however, Includes many miles of deficient highway for which a detailed method is needed to determine 


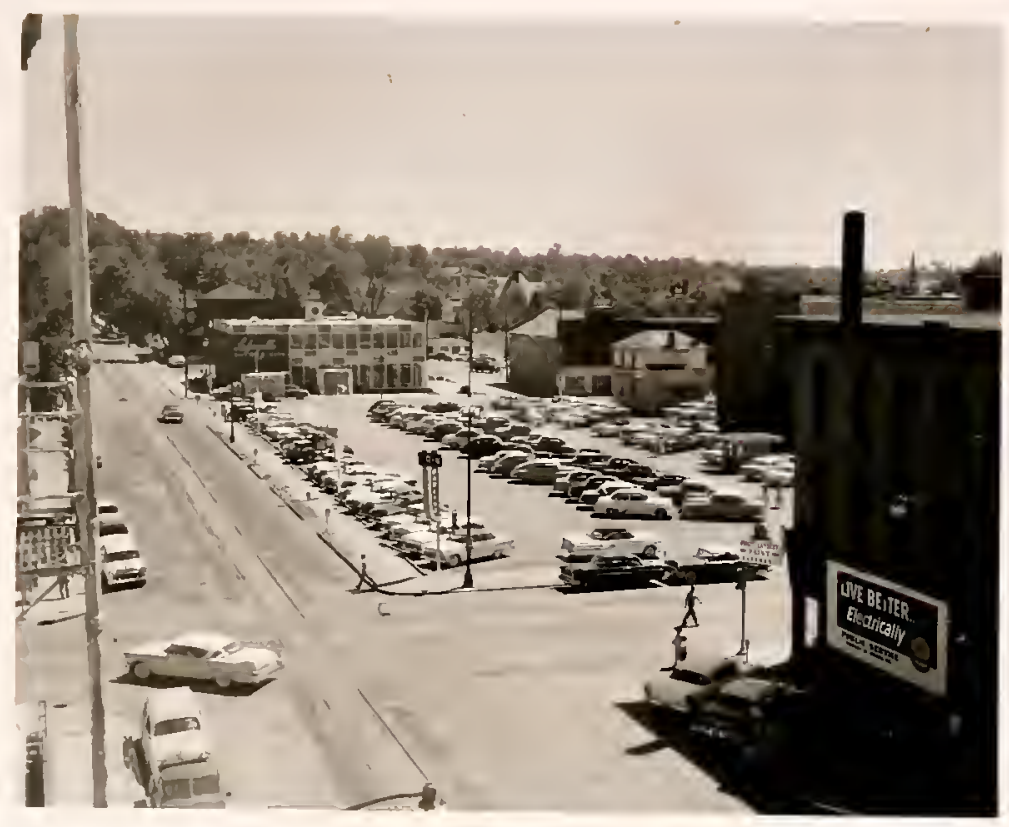

Adequate of fostreet parking faclitiles ore neaded to halp solvo the highway transportation problemo

Fuguse 64 
the prisity of individual project $\sigma_{0}$

Controls on the classification of highway systems are usually tho reais of leglslative action. However, the developant of annual project prijuties is the disect concern of the highway adninistration in each 'Arisaiction. Therafora, with proper classification of the road system, oach furisdiction should establish itg own project prioritLos by developing a logical evaluation system for ingrovement.

Project priorities can be developed by measuring the sorvice a highwsy perforss and the adaguacy of the highway to provide that sertice, GeneraIIy service 13 measured on the stato system by comparing traffic volume and capact.ty. On the county systems, sorvice is masured by existence of mail, mill, and other service routes, as well as traffic volumo. Adequacy of the highway to sorve trafflc is generally measured by the relative condition of parement; ahoulders; drainage; and geo motric design features such as pevement width, shoulder width, restricted aight distance, and horizontel and vertical alignment. Accident expezo Ience has also been used to measure adequacy of service。

Peiorities can be determined by these yarasticks, but other crio terle should also be used. It is desirable that highways be improved In an orderly manne: so a whole soute os section of a route is uniformly inproved. It would be unwise for safety reasons to retain a few miles of two-lane highway betiveen sections of fourelane divided highways. In addition, federal aid apportionments to each highway system must be considered. Technical difflculties in the preparation of surveys and plans, the procurement of right-of-way, the awarding of contracts, and unforsseeable emergencies guch as floods, may influence priority rating programs. In the development of annual programs, all of theso 
factors mugt be considered and whighed whth sound judgment by adminiso trators to avold pitialls and imyossible situationso

\section{Sufoiciency Patins:}

Sufflctency rating procedures heve been developed in resent years to ass ut in the determination of construction priosities (37). The have proved to be a valuable too. in gelecting projects for annul prograns. In the ae procedures, ach section of nighway is comparec. With accepted ideal standerds of esryice, safety, and structural cono dition. Any condition which cloes not mect these Icieal standards is given a rating which is a percentage of the deal rating; the worse the convition the lows the rating. Annual review and revision of thase ratsngs and the selestion of those projects with the lowest rat Inigs keepa the prograr gearad to the most urgently neaded improvementso The Stats Highway Department of Indiana has not adopted a suffichency rating prowedure. If e. logical prograning method is to ke eso tablfehed, a sufficiency zothrg procedure or other effective noinoc. Iust be adopted. Such procedures should also be used for county hIgh= ways and runichpol sireetso. The resuits would bo as valuable to local adninistrators as to state aduinf.strators。 
The leve? opment of highydy from bhe tinc of Indiana"s ctatohocd

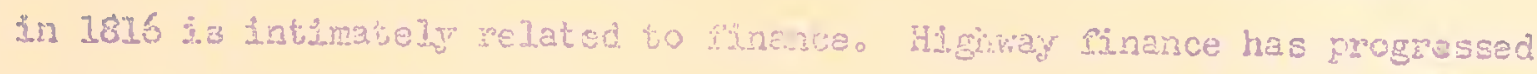

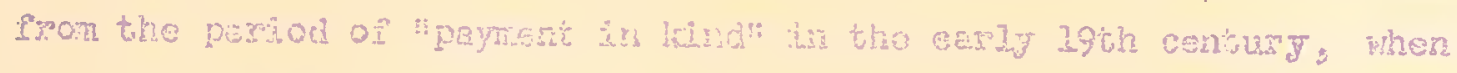

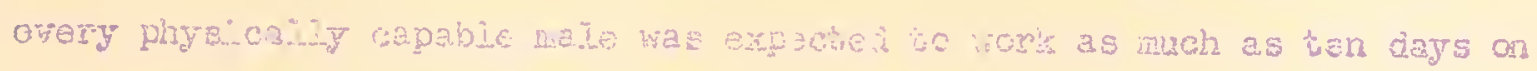

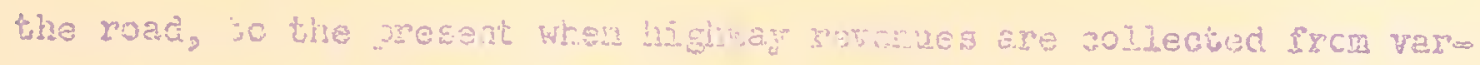
ious souri: $(13)$

The folloning discussior. Will not remand a particulas method of highway finknce or fom of allccation of the cost to the nishway

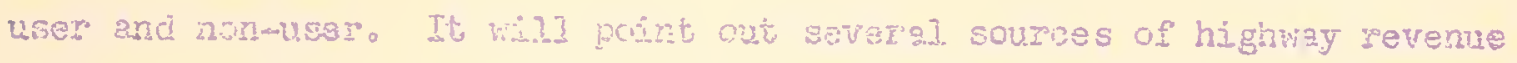
that have besn used in thes past and thoss that are now being usedo

Ir 1792 the Covernent sf the Northest iexnitory authorized tho annual apoointment of responstbo inoviduals to suparvise road hork in each tomrhip. Under the sygtem estabiashed, every physically capable male citizm orer 15 ysars os age vas required to vork ten days per year

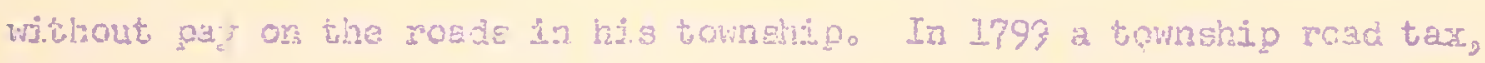
to de assassed parsone who dic not perforn actual york on the road, was authorized. These pratices continued for nore than a century

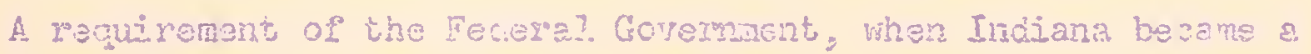
state, porded that five perent of the net procesde from the sale of proble lands in Trdiena sinculc. be zeaerved for the eonstruction of roads and canali, Threorilibs of these reserved funds vere given to the now state govenmert for axpencitures on projects within Indiana while the remaining iwo-fifths were used by the Faderal Govemment for the con= stmetion of the llational Poad (now U. So 40). Noney received from the 
"three percent furd" for rain yars constiuted the only aid to the

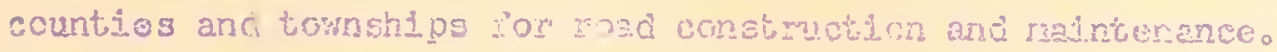

From statehocd to abou, 1550, the wrians Iogfolature used a "spectal act" to finance the constrution of highways A state Corn Missioner Wes apolnted to distributo the "three percent fund to the countes, and m severà pecisicre ha the slature nade grante from

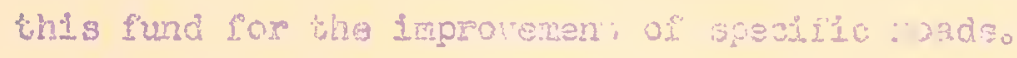

In 1835, the Inteme1 Tmproversent. Ac. provided money, obtaired

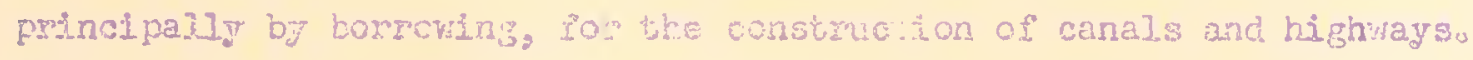
Tris venturo in cond financing did not prose financielly successful and the state becare buxdened with a debe which could not be pajdo

As a zesut of these finangiel fainues, the state constitution provided, when revised in $1831_{2}$ thet no law shall authorize a debt to we contracted on tahalf of the ctate axcept in extronely limín condi

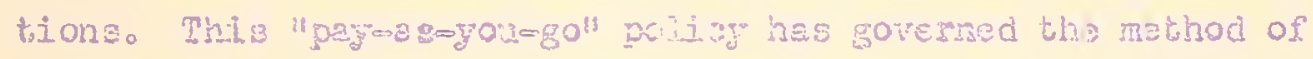
financing the highweys of Incicusa to the present tine

\section{Grouth of Noderg Hohway ganneing}

The dewajopent of the motor vonicle canged great changes is highvay financingo Sulor to the development ot the motor vehicle, aighway funds came Pron local property tautiono As the motor vahicle grew In Importance, the major soures of highway furcs shifted ifrom a tax on

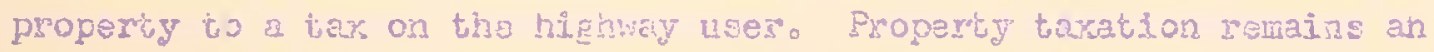
inportent source of highry gevenuc to cities, but lto inpontance to countoies as a sowes of highway devenue hat diminished greatily in recent year9. Furds from the property tax have not been used on the state gysters since 1825 . In perent jears rotor fuel taxes and regis= tration foes have supplled most of tha highway fundso Federal efd 


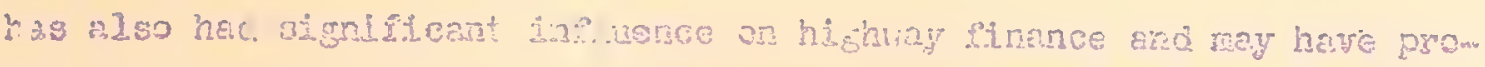
found influence in the fluth?

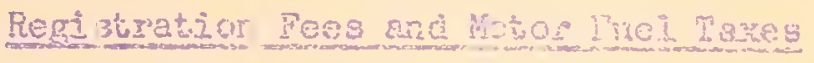

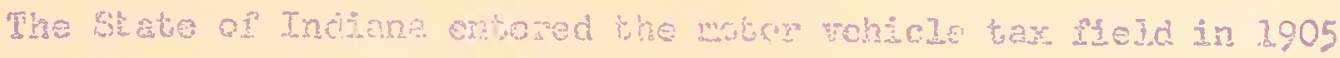

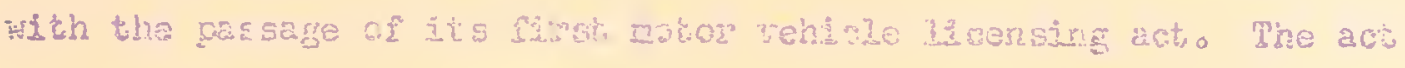

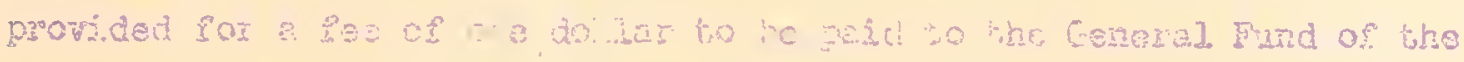

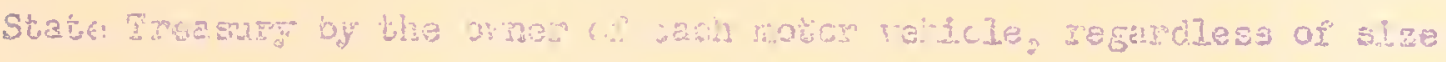

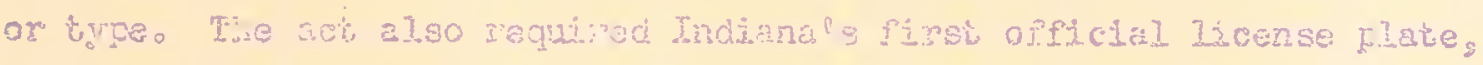
a cireular disk two lrahes 1r. distotero

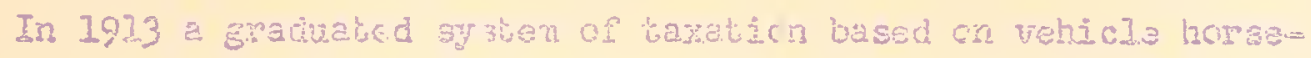

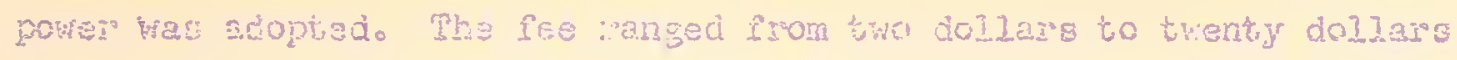

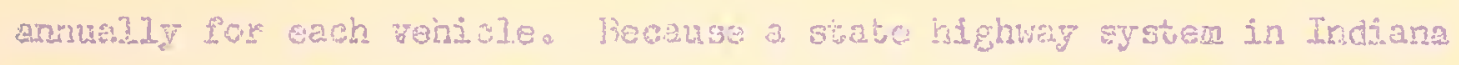
Was not esteblighed at that hns tre entife reyenue, Iess the cort of supplies, operation, and amincetration, fies apporticred to the coun-

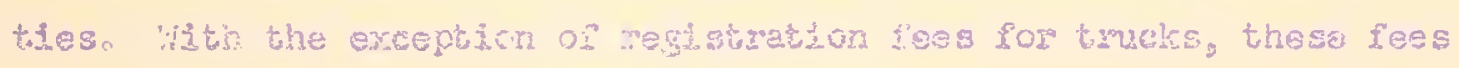
remained the same unti 1923.

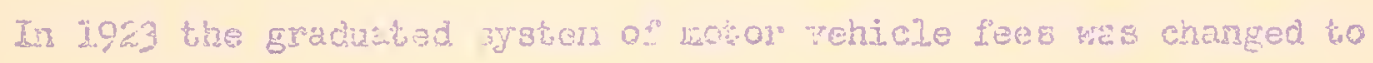

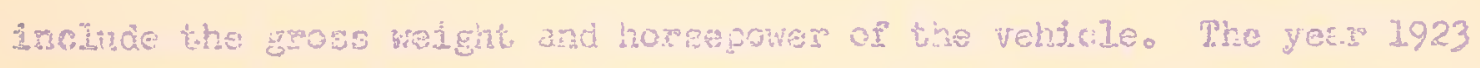

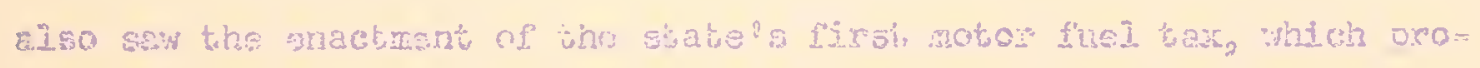

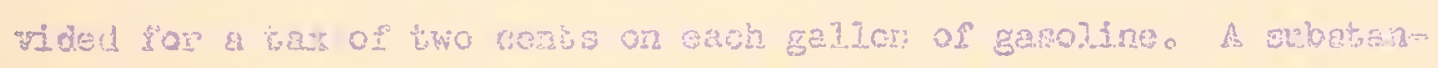

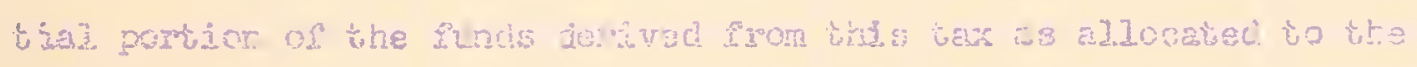

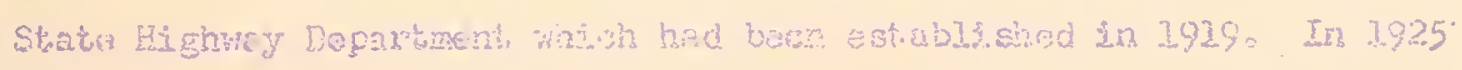

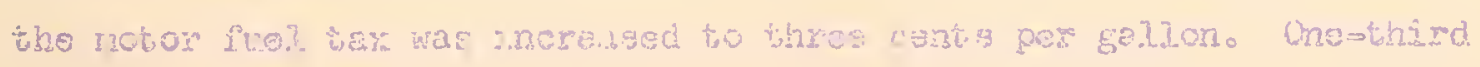

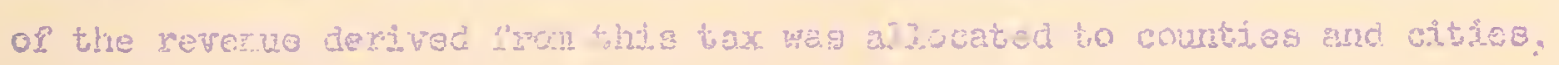

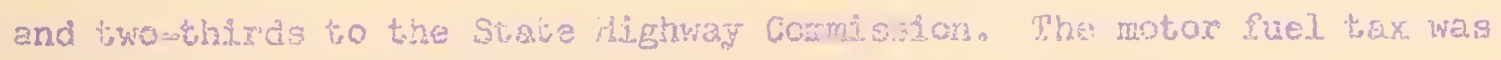
increased to four cants per gुllon in 1929. Three-founths of the sevenue derived from thi.e tar wes allocatce to the state Haghry 


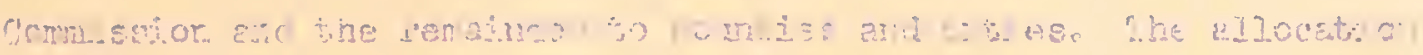

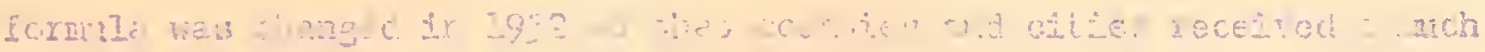

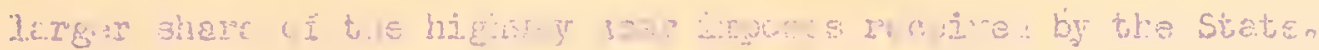

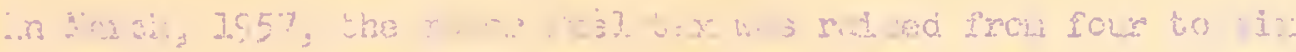

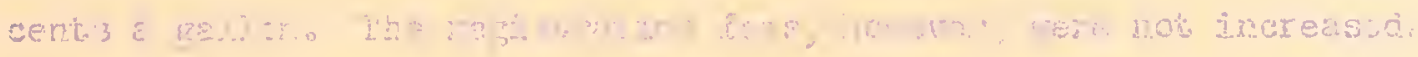

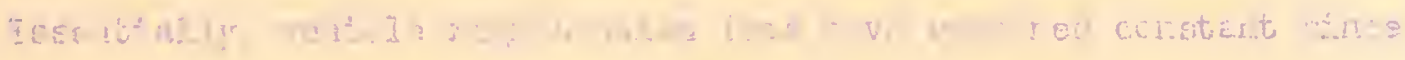

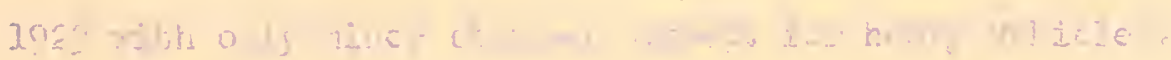

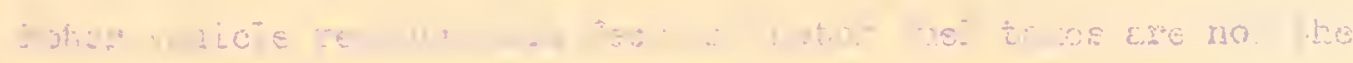

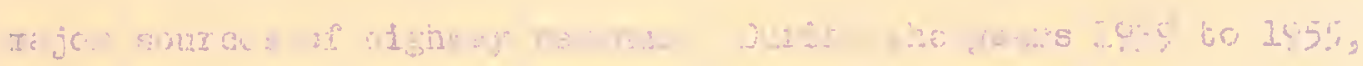

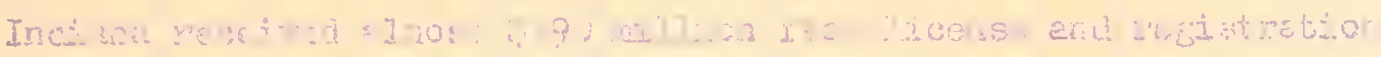

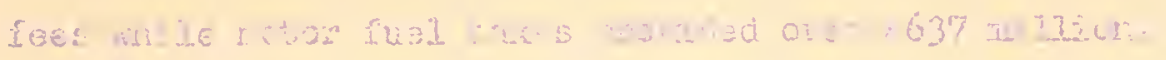

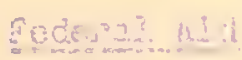

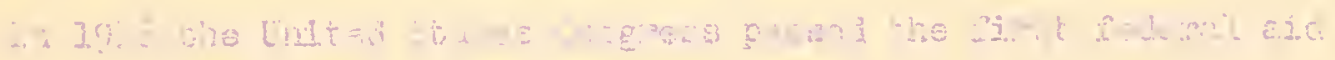

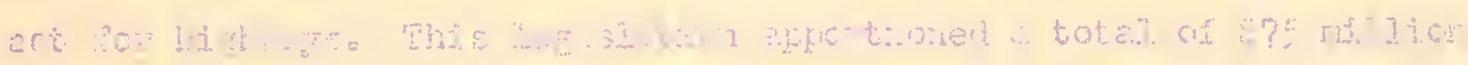

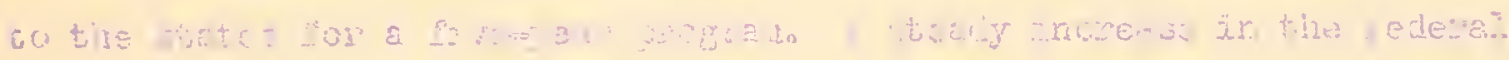
azd $1 \dot{1}$ - a

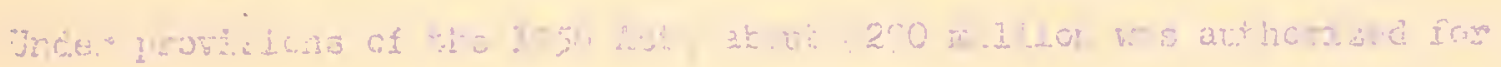

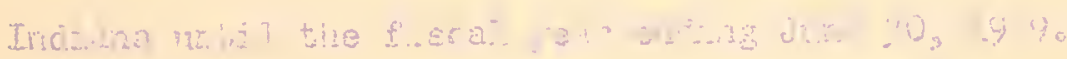

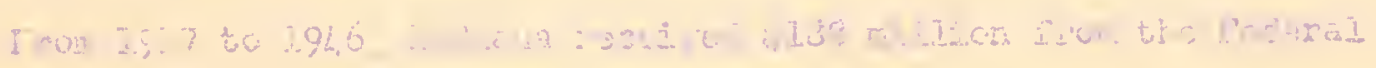

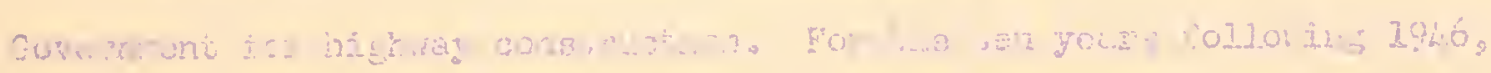

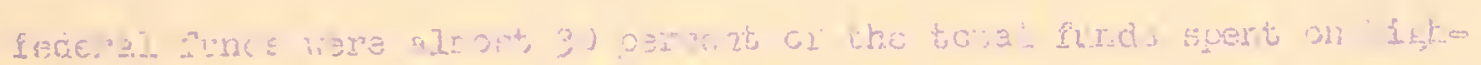

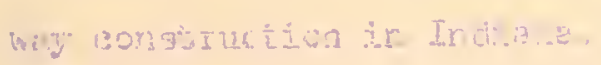

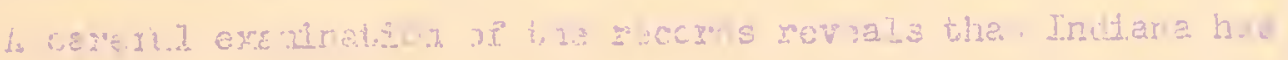

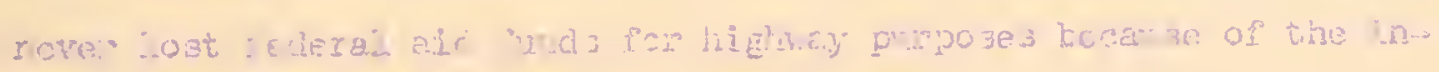

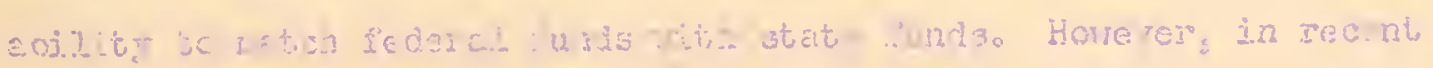

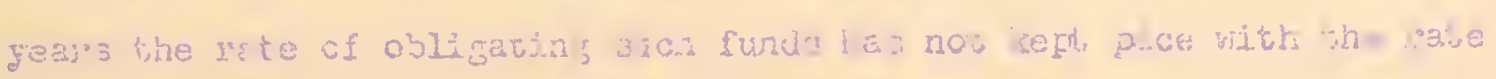




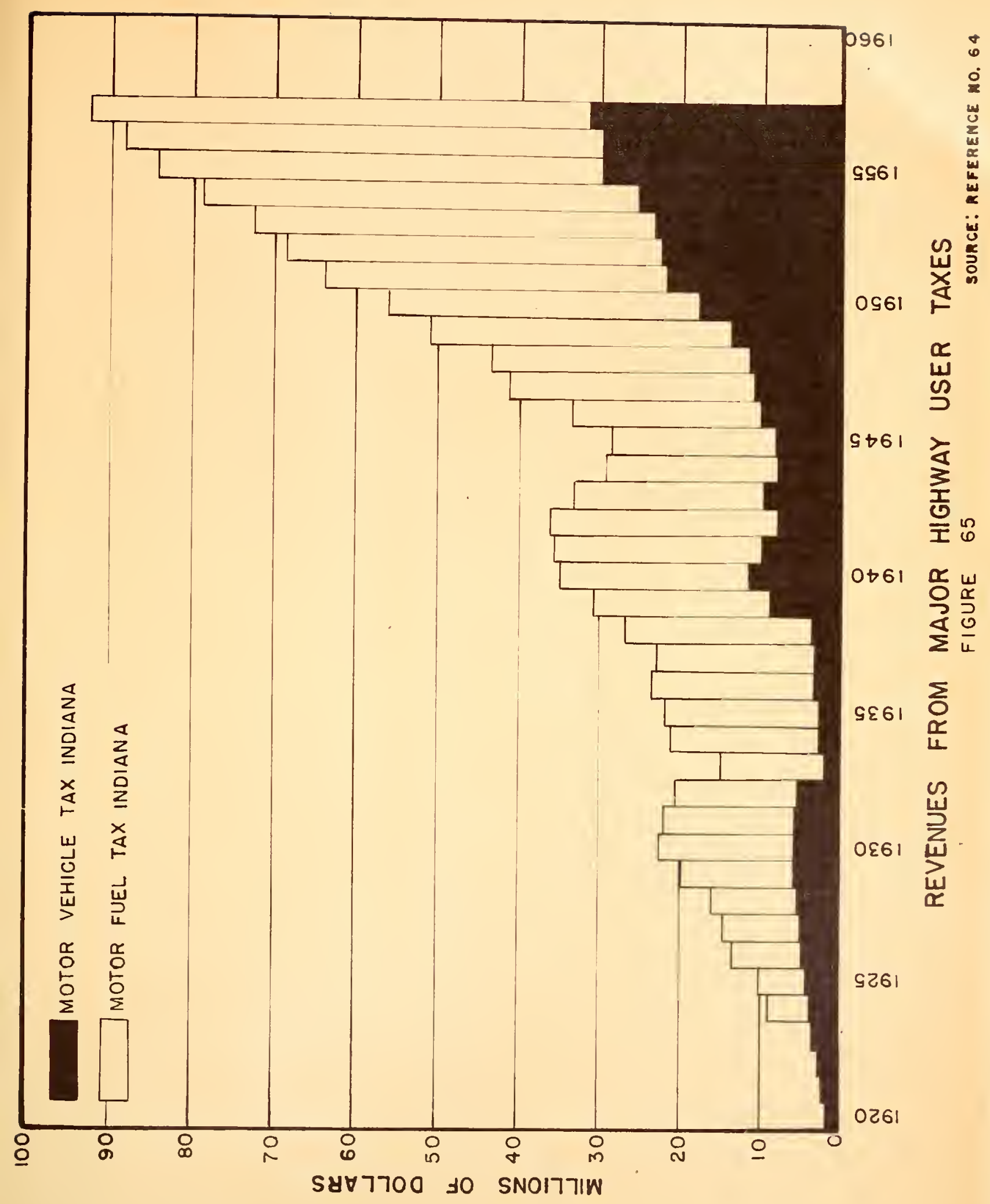




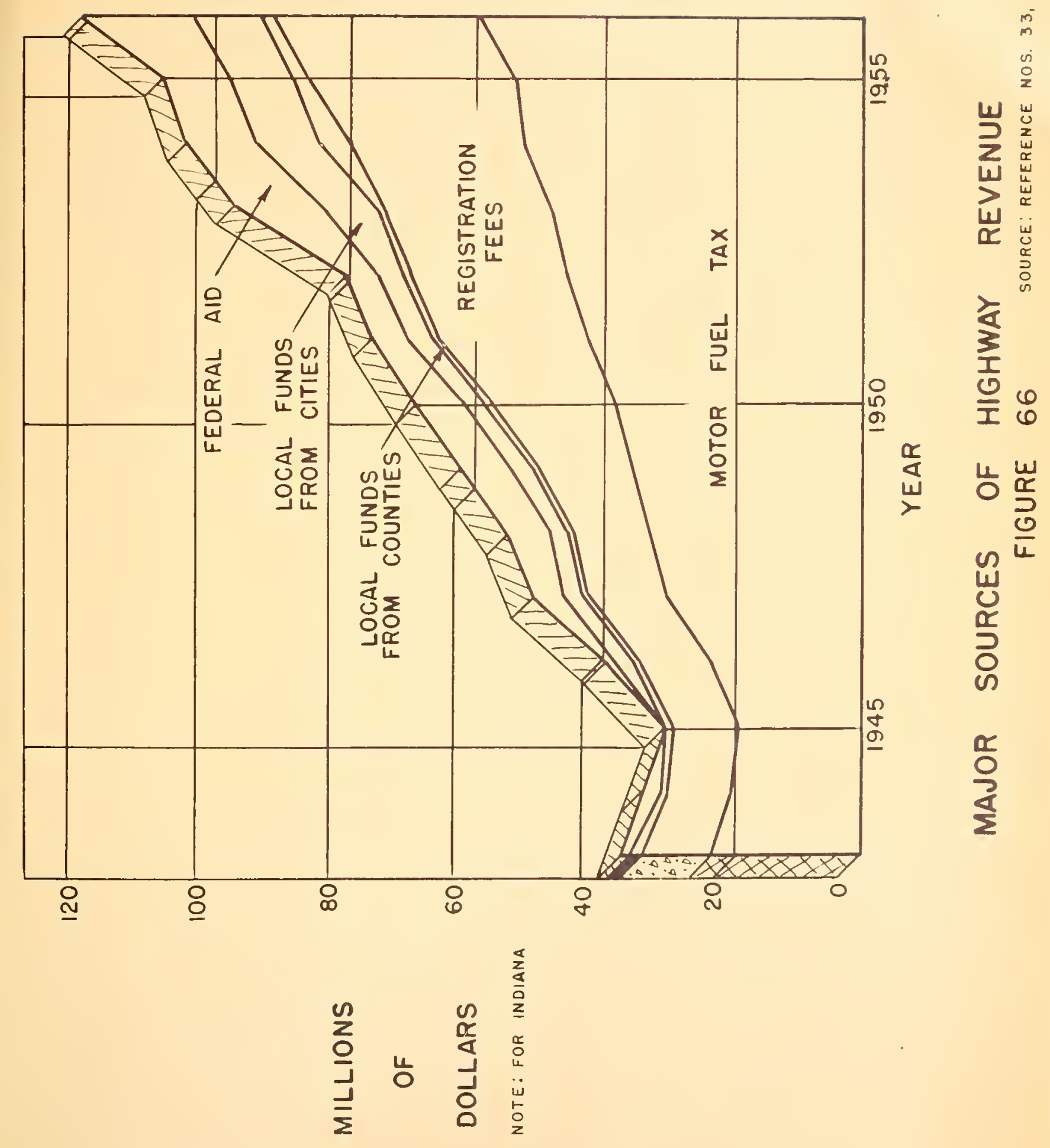




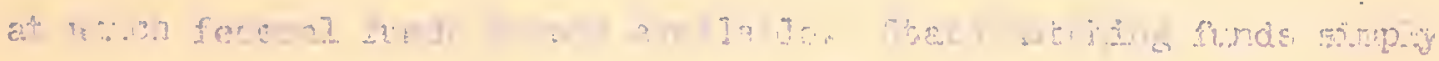

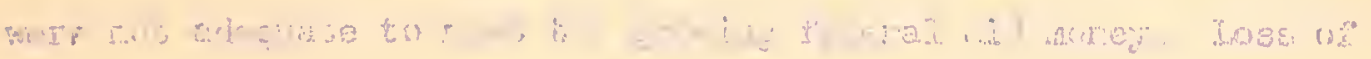

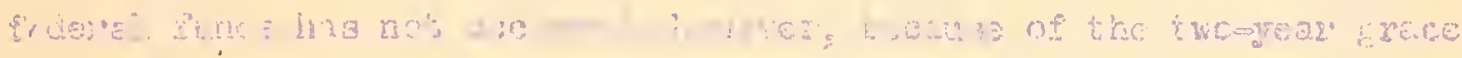

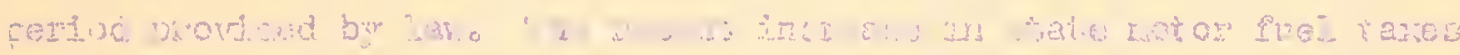

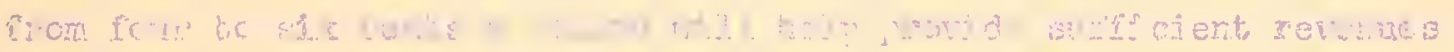

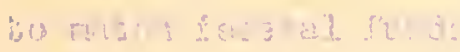

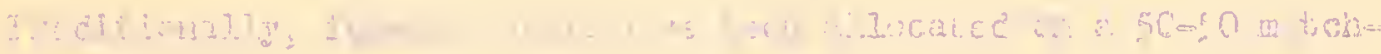

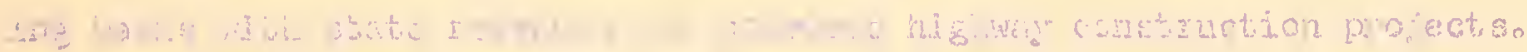

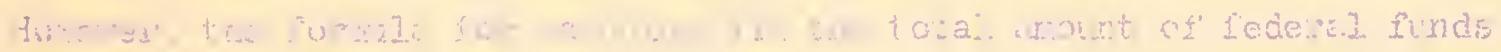

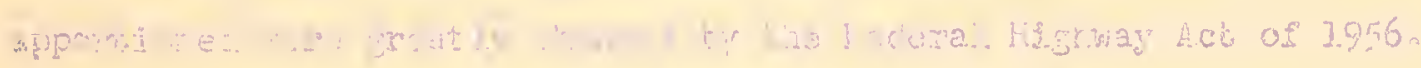

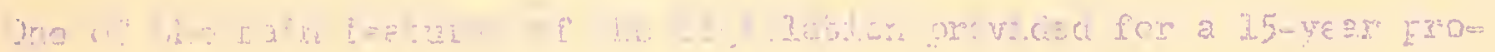

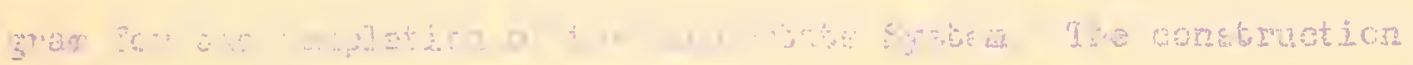

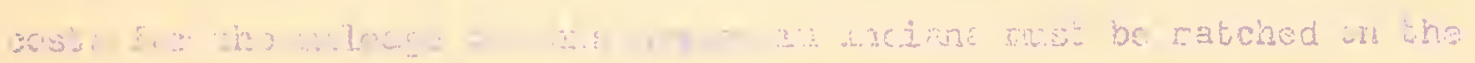

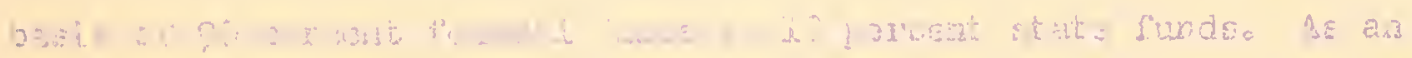

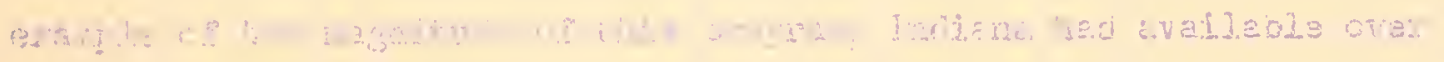

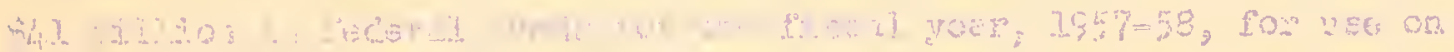

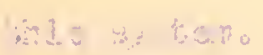

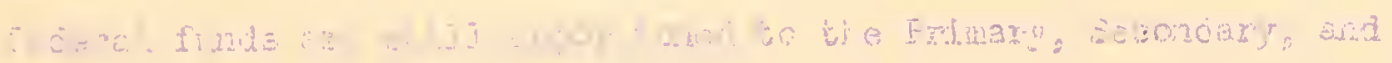

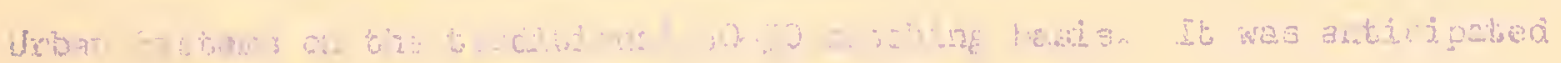

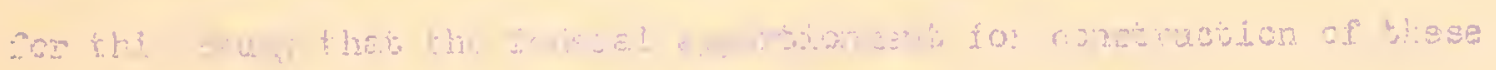

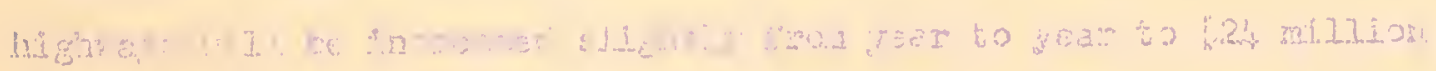

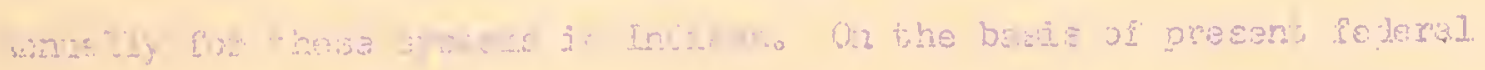

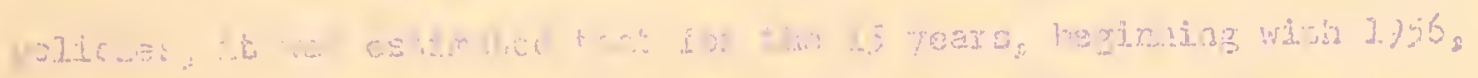
-0.

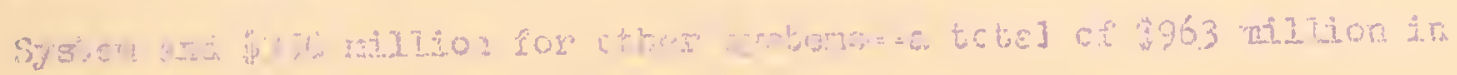

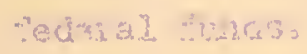




\section{Property Taxation}

The importance of property taxation as a source of highway revenue has declined during the pat 30 years. In 1955 only seven percent of the total county revenues for highways came from property taxation or other local sources, and most of these funds were derived from a cum lative brldge levy. AII funds for county highway construction and maintenance came from the Motor Vehicle Highway Accounto

Property taxation and special assessments have always been an Important source of revenues for the cities. In 1955 nearly 44 percent of the total street funds wes obtained from these sources and the remaining anount was derived from the Motor Vehicle Highway Account。

Funds from property taxation have not bean used on the state systems since 1925. AII of the state revenues presently used on these systoms are obtained from the Motor Vehicle Highway Account.

\section{Motor Vahicle Highway Account}

In 1937 the State Legislature established the "Motor Vehicle Higho way Account" as \& furd of the State. Receipts from recistration fees, motor fuel tare and funds from miscellaneous sources are credited to this eccount. Funds from this account are distributed by the state Auditor to the cities and counties and to the state Highway Department. The distribution of these funds has been changed by the State Legislature in the years 194\%, 1943, 1947, and finally in 1949. At the present time, the net amount of this fund, after deduction of administrative costs and appropriations for the Division of Public Safety and for the State Police Department, is distributed as follows: 
For the fiscal year ending June 30,1955 , the cities received 12.7 million, the counties 27.1 million and the State Highway Depertment s/4 409 millton from this Account.

\section{Funds Diotributed in 1955}

State

The total funds available for hlghway purposes on the state systems are derived from monies distributed from the Notor Vehicle Highway Account and federal aid. Federal aid fund allocation is divided between the Interstate, Primary, Secondary, and Urban systems. The total made available in 1955 to the state systems from the Hotor Vehicle Highway Account and federal aid was \$56 million (64)。

\section{Counties}

County highway funds are derlved mainly from the Motor Vehicle Highway Account. Since 1944, federal aid funds have also been made available to counties for use on approved Federal Aid Secondary High ways。 In 1955 funds from local sources -property tax levy for use only on bridges- amounted to less than 10 percent of the total revenue for highway construction and maintenance. "lotal funds made avallable in 1955 from all sourcss amounced to 30.7 million (33).

\section{Cities}

The princlpal source of revenue for the city street system is the distribution from the Motor Vehicle Highway Account. Local sources of revenue, however, are responsible for an appreciable portion of funds for the clty streets。 Local funds in 1955 amounted to approximately \$O millon, and the funds derived from the Motor Vehicle Highway Account 
for that year were $\$ 12.7$ inllion. Funds from all sources for city street construction and maintenance were epproximately 24 milizion (34)。

\section{Expenditure of Highwey Funds}

Highway funds are spent for three highway functionse-construction, maintenance, and administration. The distribution of funds for these highway functions vary between highway agencies. Difference in traffic, the extent and condition of the highway network, and the past and present funds available result in widely different expenditures on the various highway systems。

The accompanying chart indicates the construction and maintenance expenditures for 194601953 on the state, county, and city systems (75)。 Administration expenditures are included in the construction and mains tonance costs. Expenditures for the state systems are primarily for construction, and expenditures for county roads and city streets are primarily for maintenance. It is a fact, however, that some of the costs that were classified as maintenance were construction, because past accounting methods have included some construction expenditures with maintenance costs.

\section{Other Factors in Highway Finance}

Highways are constructed, maintained, and administered by using equipment, labor and materials and are affected by inflation of costs. Since 1939 costs of highway work have risen steadily because of economic conditions during the war and post-war ora. According to a highway.construction cost Index developea by the Bureau of Public Roads, the highway dollar in 1955 purchased only 79 percent as much as it did in 1946 and only about half as much as it did in 1932 . 


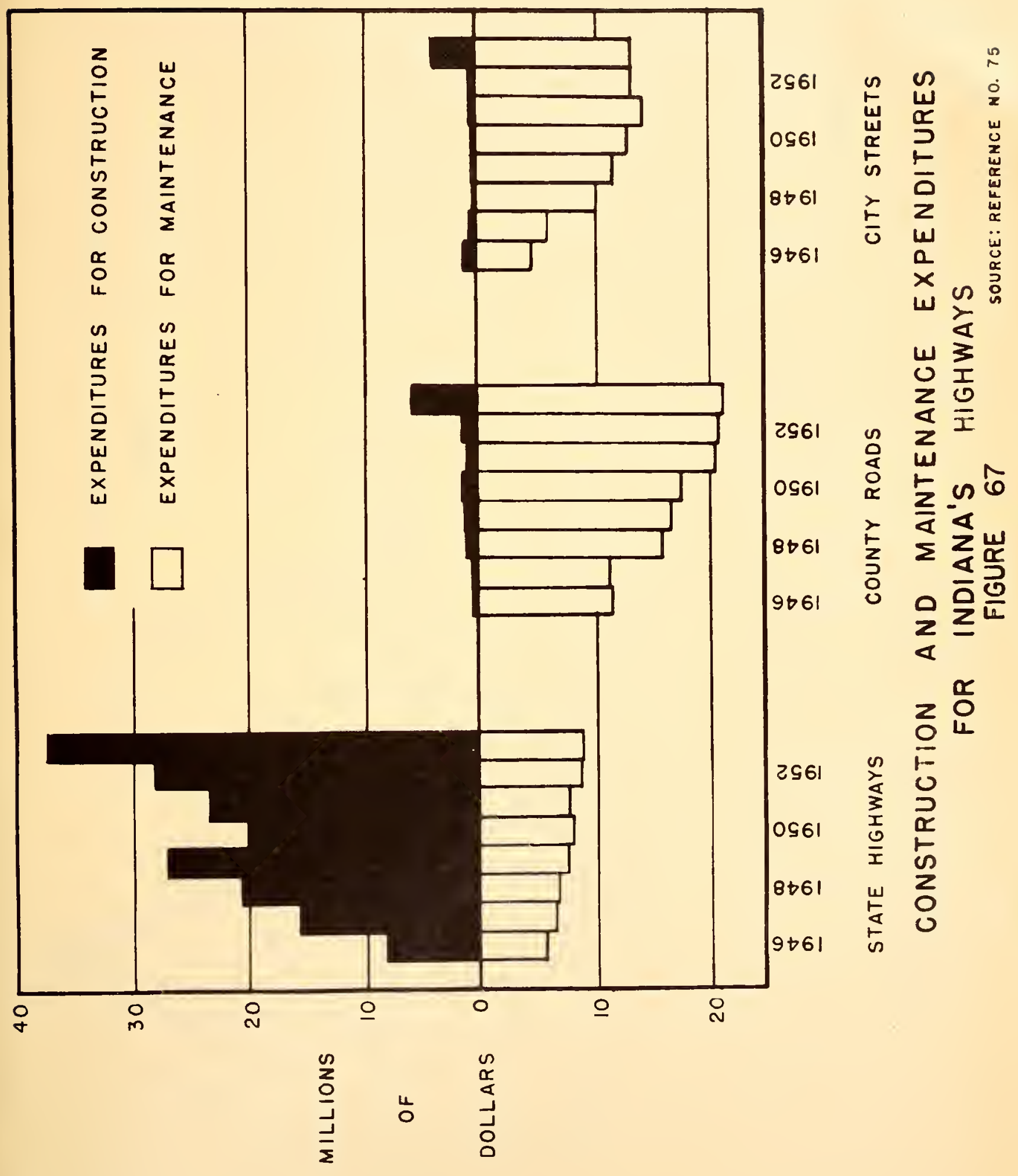


Other conditions of. najor importance affect the cost of highway conjtructione Standards of highrey constmuction have contirially in rieased, and it is possible that they Nij increase in the fut iro. Certainly the availability of funds will greatiy influence the 1 . te of structurel obsolescence of the highnay. Frotection of the highway in

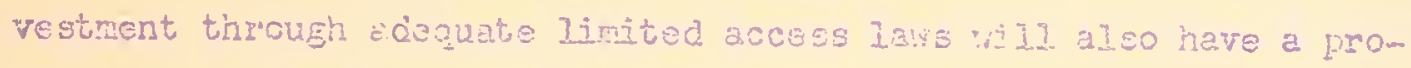
rounced influence on preventing functonzj oweolaccerce. Al1 of these itsm have an effect on the uitimete highiag costo

\section{Adeguacy of Our Presant Fiseal Fogram}

The passage of the Federal Ad inghvay Act of 1950 and the $2 n=$ crease in siate notor fuel tazes early in 1957 vilil resul'c in wore dollars Por bighwy construction and raincenance in indana. whe projection of the revenues from local sources, the wotor Vehicle highway Account, and estinated income from federaz aid uill rot, however, viela suricienc funds in tho next 15 years to eliminatse el. of the higiway deficiuncies。

\section{$\operatorname{Con} 13 \sin 0: 2$}

The highway riscal policies used in Indizne ase the reaults of exporience and attitudes that devaloped in expanding che state from a frontier widerness to an industrial and agricultural center of the midust, The trend in hjghray finance is that the highway ugero, through vahicle and motor fuel taxeg, is providing increastig revenue por highe vays. In 1955 the highway user provjded nearly 86 percent of the total highway funds, excluding Federal Afd, avalable for highway improvenent In the sitate. 


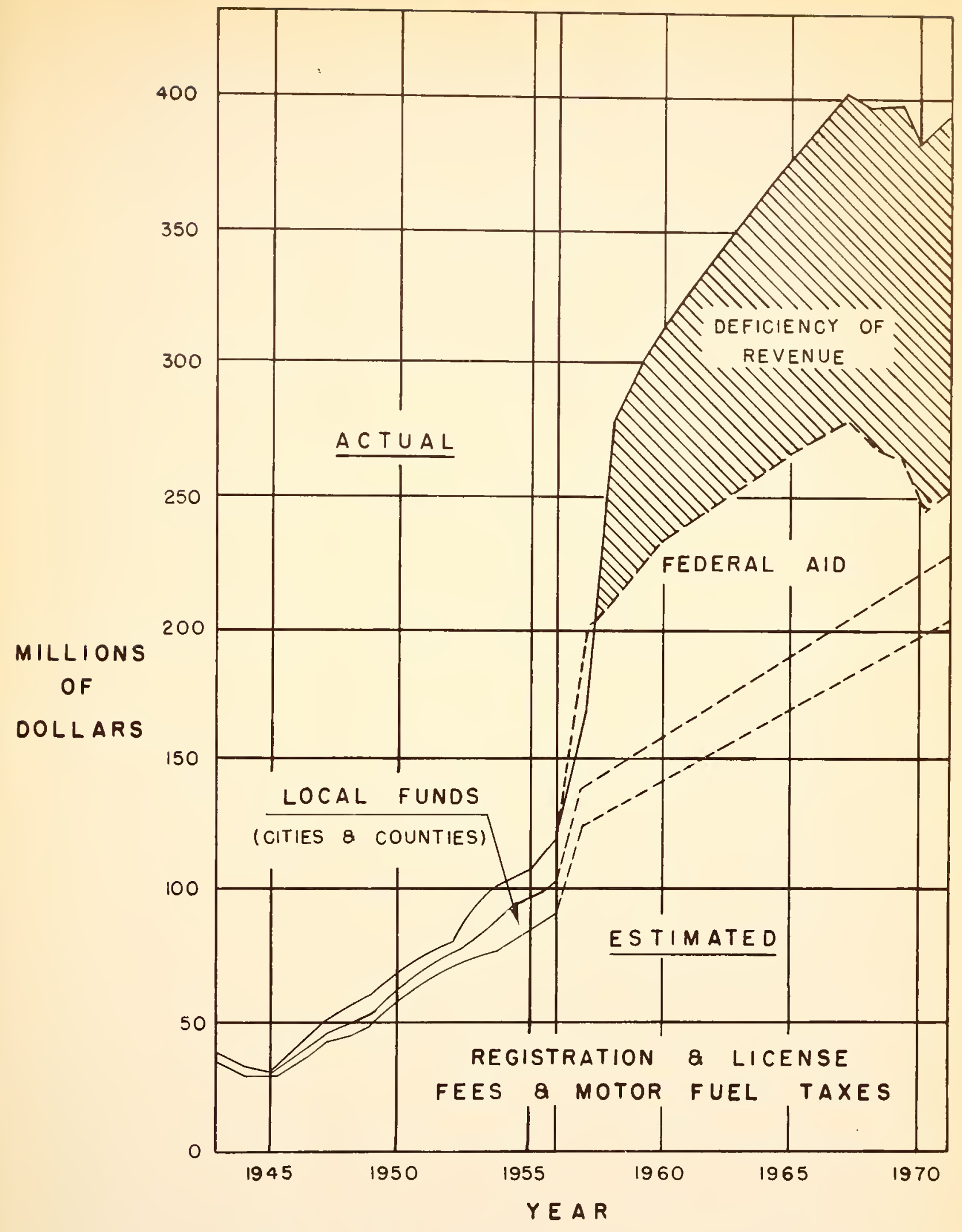

Estimated REVENUES \& NEEDS 
Alshough Congress has incrcased Fedora?. Hod to Indiand and the General Assemoly hasincreased motor fuel taxes, money to eliminate 212 deficiercies wthin 25 years wil not be available under the fiscal polfcies: 
1. Accident acts, 1955 Fittion, Mationa? Satety Counct.

2. Acts of 1945. Indiana GeneraI Asgembly, dith SeseIor, Chaptor 245, Boolwalter Corpany. Indlanapolis: Indiana.

3. Acts of 2953. Indiana Genera]. Assembly. 89th Segston: Chapter 297 BookweIter Conpany, Indianapolis, Indiana.

4. Annul Inventories ano Priorities for tho fighway pogran,

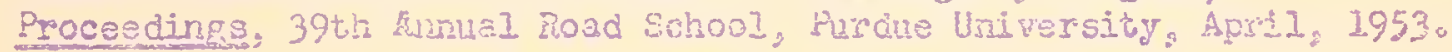

5. Anual Report. Interstate Comerce Commission.

6. Automobile Facts and Floures, 36th Edition, Antomobile hanufacturers Associaticn, 2956 .

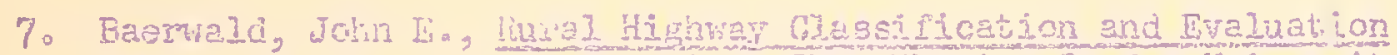

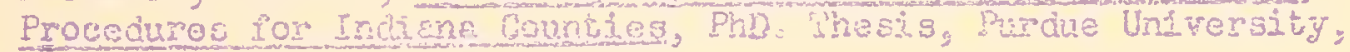

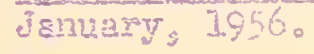

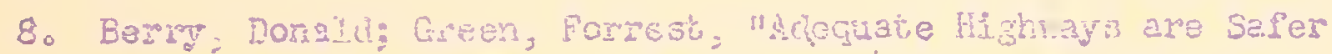

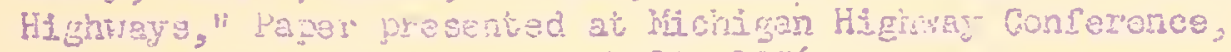
Grand Rapids, Michigan, Mareh 13, 1956.

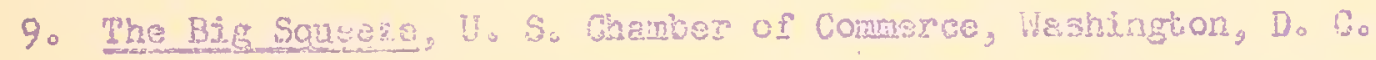

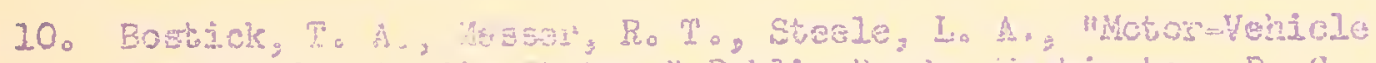

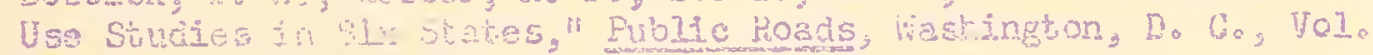

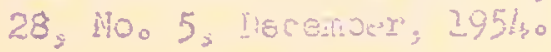

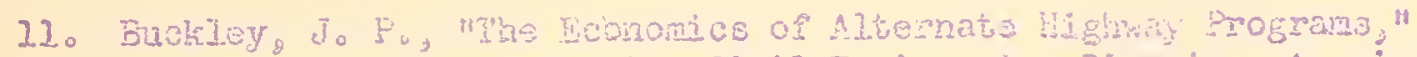

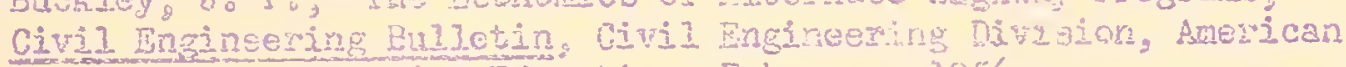

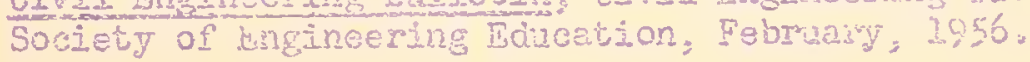

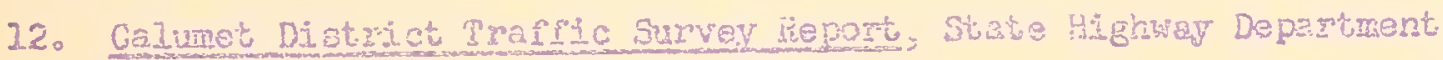
0 Indiana, 1953 .

13. Campbell, Gorton Eog "History of Highwey Rimance in Indiang," Purdue Univeresty (Unpubished).

14. Classificaton of ILlinois Highways, Dopartment of Eublic Works and Duiddings of the sute of IIlinojs, Narch, 2951.

15. "Conducting Long-Fenge Highway Needs Studies" Public Eoaco. Decerber, 194.8.

16. Count Road Harsgenent, National Association of County Ingtreerig, Wishington, $D_{6} C_{0}$

17. Covauli, Do Ua, Branhare, so Ko, Michael, Ho L, "Progress Report on

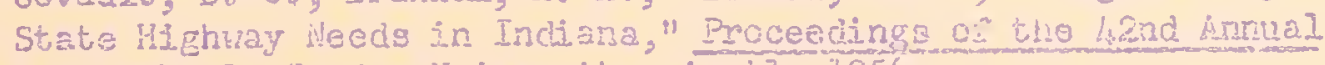
Road 5cioo], Purcue Iniversity, Aptil, 1956. 


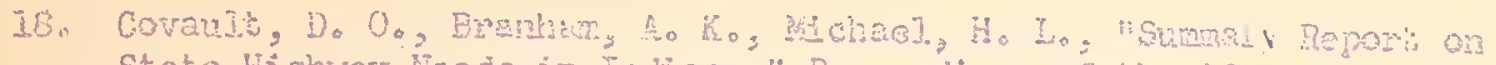

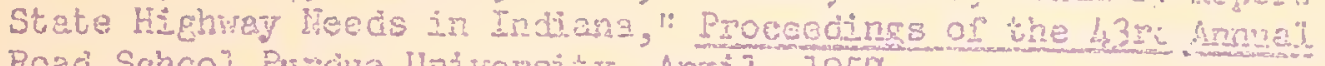

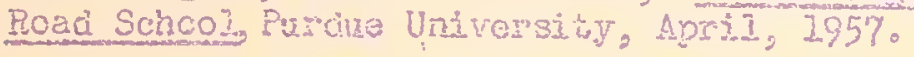

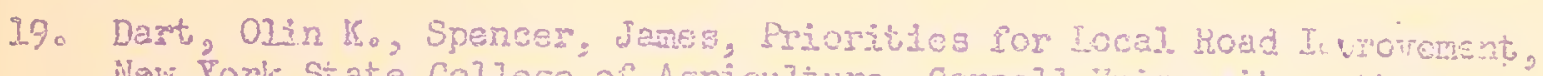
Nev York State College of Agriculiure, Comeln Univority -lhosa, Hew York, SeDhmber: $195 \%$

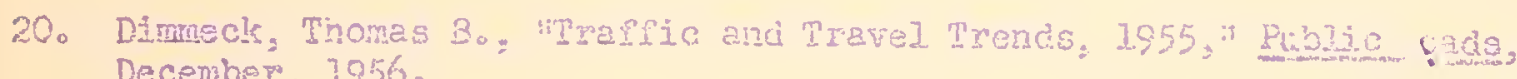
December, 1956 .

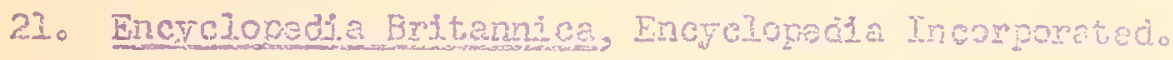

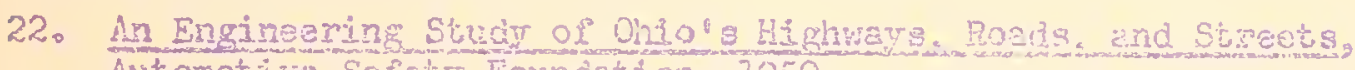
Autonotive safoty Founcation, 2950.

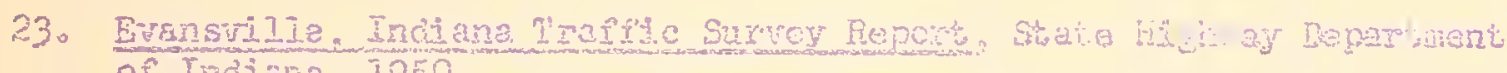
of Indisa, 1950

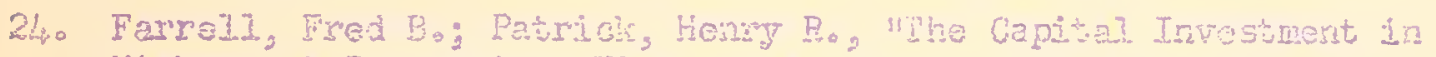
Highays," Procaedings, Highway Research Board, Vashingtan, Do So 1953.

25. Farel], Fred Bo, HTrs Investnent Analysis Appoach to Eatrating Highiay Needs," Prooesuines. Higlivgy Fosearch Board, Vol. $35,1956$.

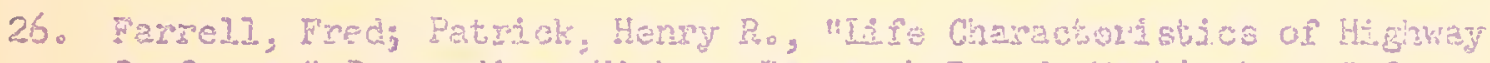

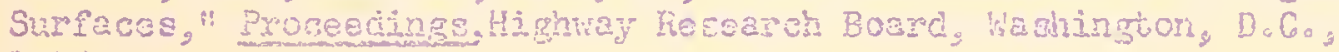
1948 .

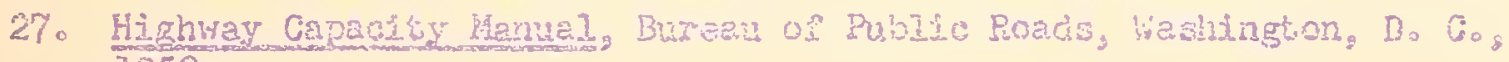
7950。

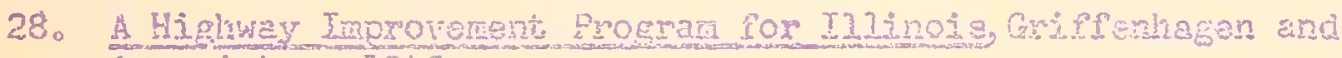
Associatos, $18 / 8$.

29. "Righway Needs Cost Lstinsbes: A Stroogtur," Hijghway Regearch

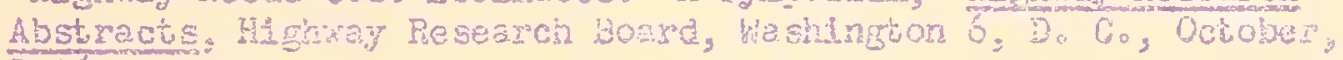
1956 .

30. Mighway Piar fat For kavie, Inciens, Stats HIghay Departrent of Lisciana: 1946.

31. "Highray Practice in the United States of America," U. S. Hublic Rosds Adwintstration, Wasington, Do Co, 394.9

32. A Hz rhway Progzan for Kentuciry, Automotive Safolg Foundation, 1955.

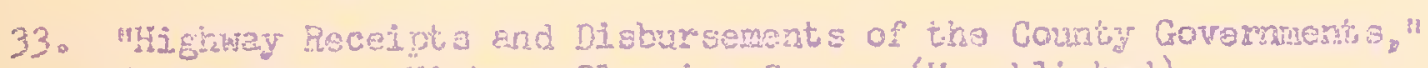
Indiena State th ghway Planuing Sugvey (Unpublished). 


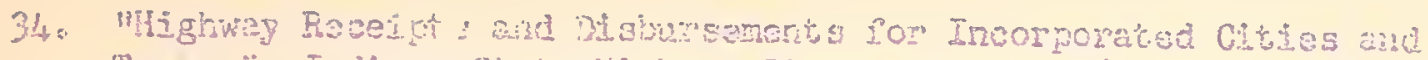
Tokns: Indana State tii gindy Plenning sumey (Unpubitshed)。

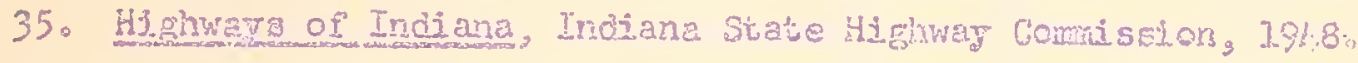

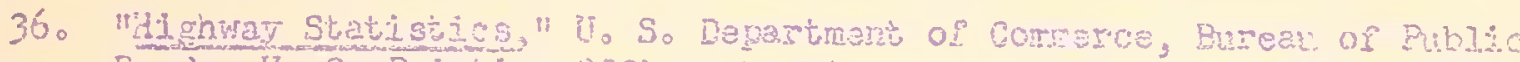

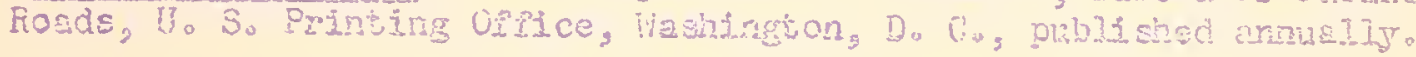

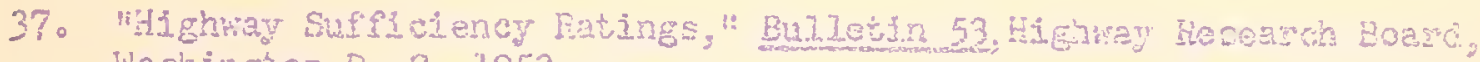
Wasington, D. 60, 1953。

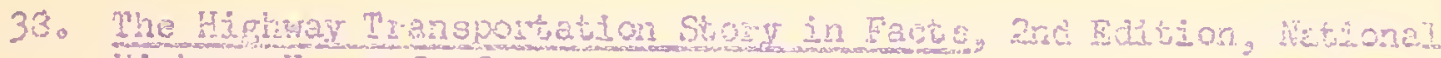
Highry Usorg Consesence.

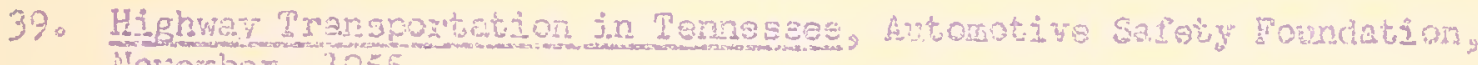
ivverbor, 2955

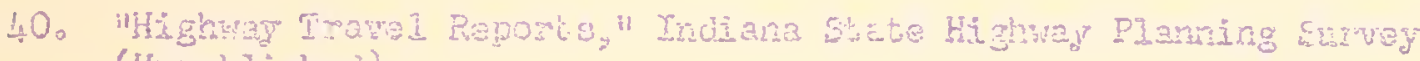
('npitalisued)

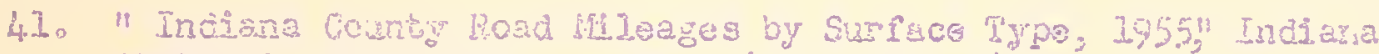
Stato jighray Planning survey (Unpiblished)

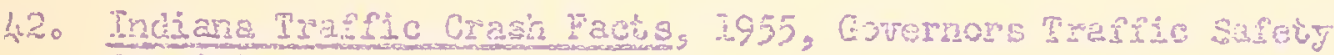
Comittee.

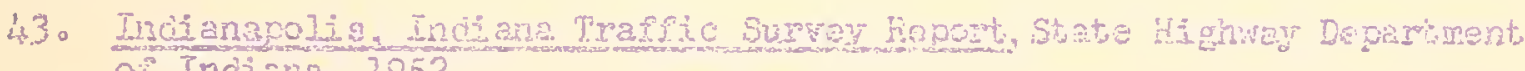
of Indirie, 3952 .

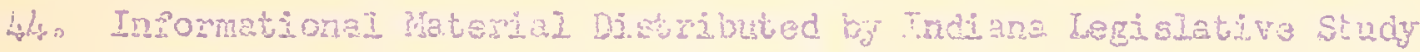

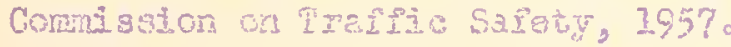

45. Lsuatuc, $\ddot{n}$, Laxa,

Frinceton liniversty fresa

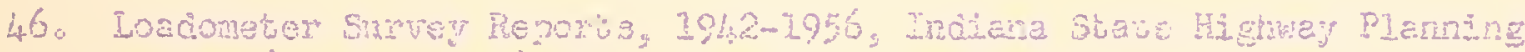
Survey (Unpuliz shea).

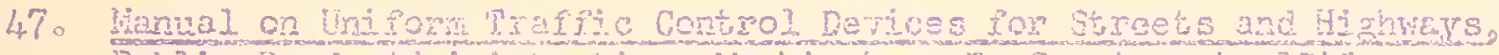

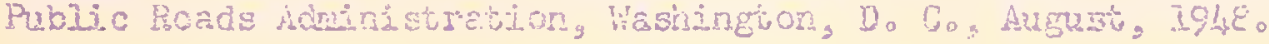

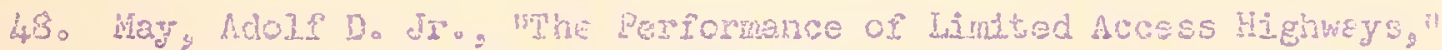
Procerdings of Highnay Bosearch Board, 195\%

49. McDoneId, jo Wo, MRolation Betuen Number of Accidents and Iraffic

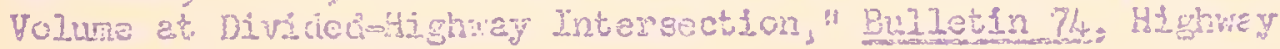
Research Bogrd, 1953 .

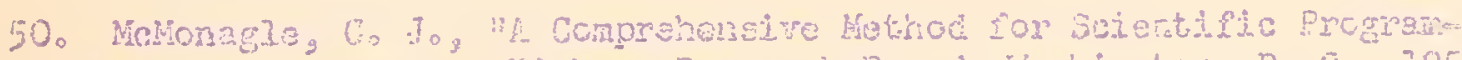

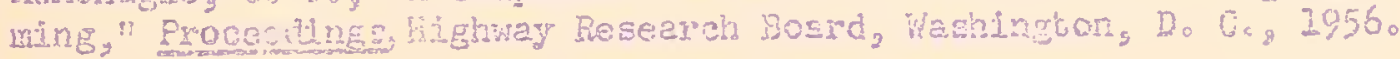




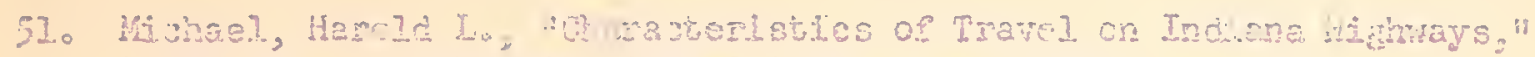
Frocosdinga of the loth dmunel Purcius Road Sohool, JuIy, 1954.

52. "Hileages of Stroets in Incorporatod Cities and Totns in Indiana, 1955, "Indiane State Highway Planning Survey (Unpublished).

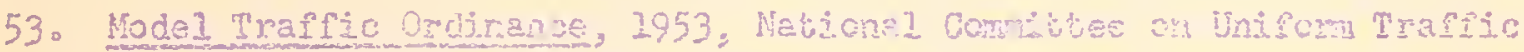
Lewis and Ordineinces, weshington. Do Co

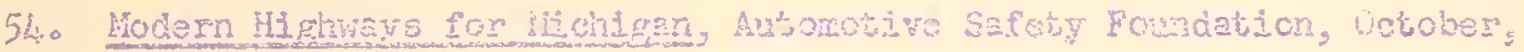
1955.

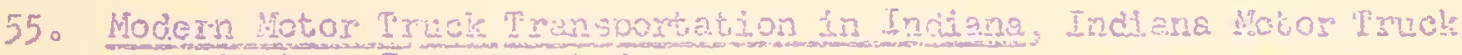
As30ciation, Incorporatcdo

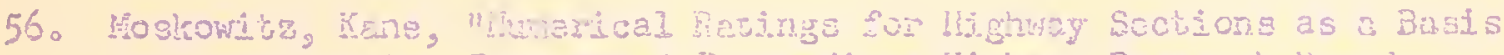

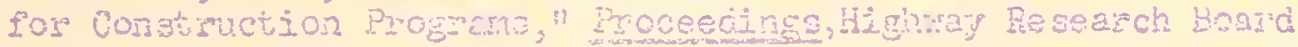
Hashington, Do Co, 1947 。

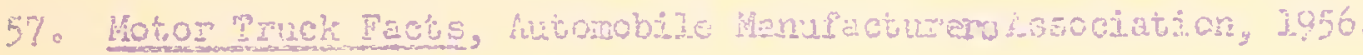

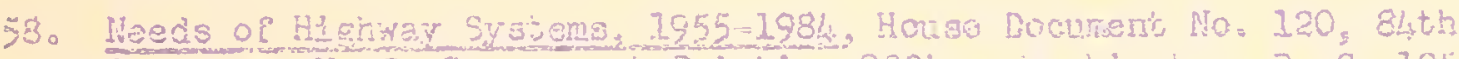
Congres3, U. S. Govemmert Printing Depice, washington, Do Cog 19550

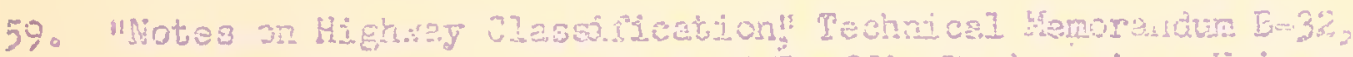

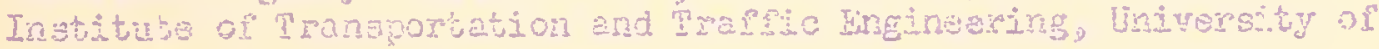
Celiforais, Cot. 7 , 1955 .

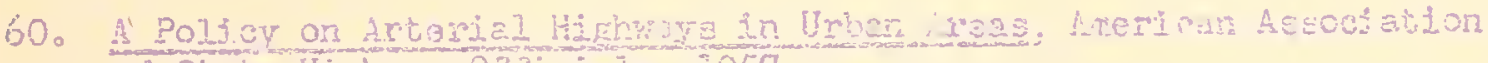
Ot Stat Hishey oficieis; 1957 。

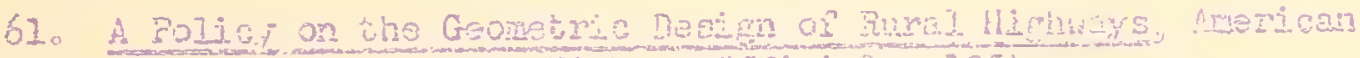

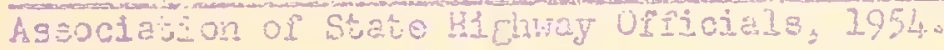

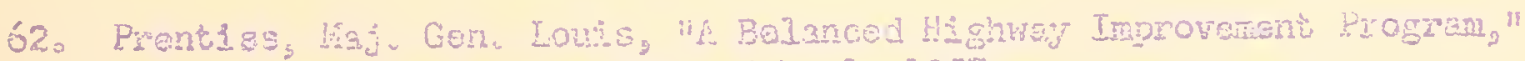

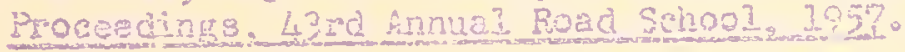

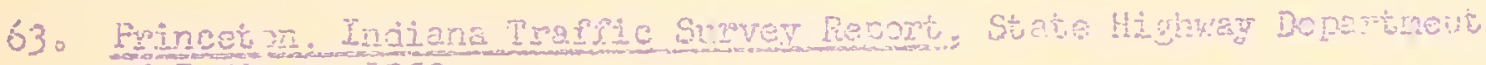
of Indiane; 19530

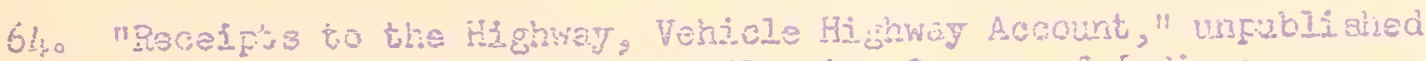
roports by the State Highwar Planding Sirvey of Indiena

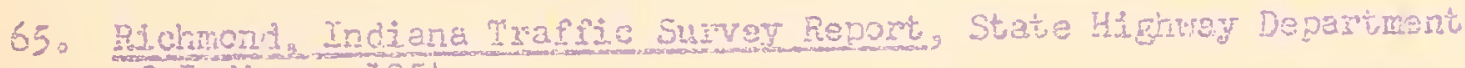
ô Indiana, 19540

66. REederel, Go ko, The Unifon Cost Ascounting Sygten Used in tho Courties of the stato of Uashington. "Scper presented at the 5 th

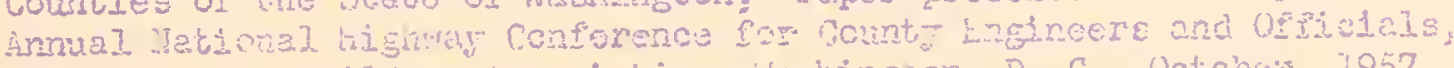

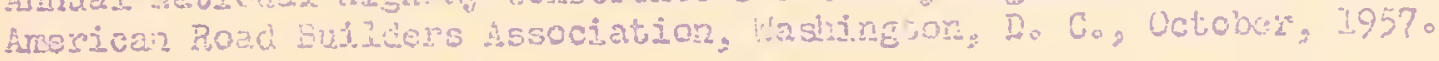


67. "Road Spgton Lesignatjon:" Technded Hamorandun B-30, Institute of

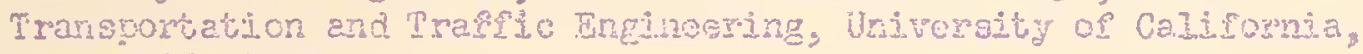
August 10, $29550^{\circ}$

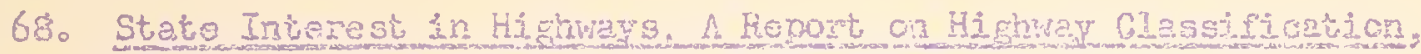

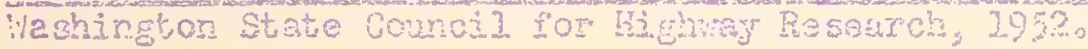

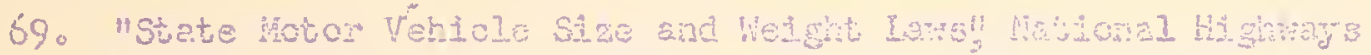

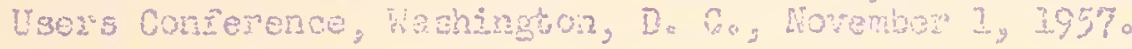

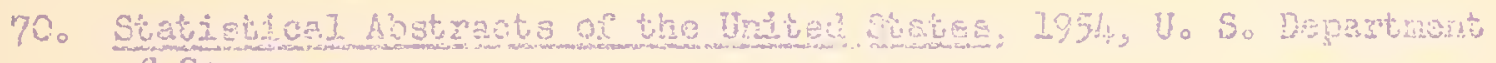
ot Comerce.

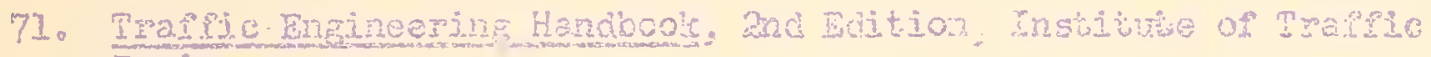
Engineris:

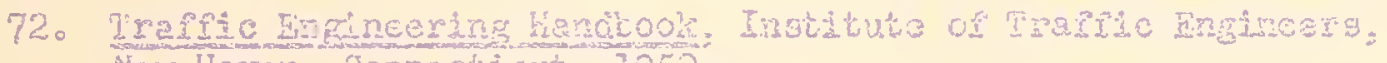

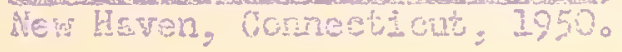

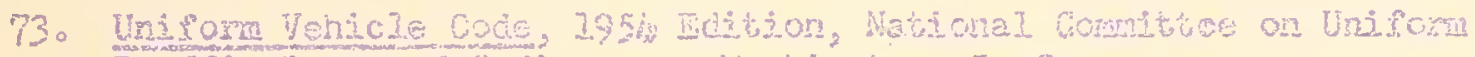
Trafic Levis and Wedramos, hashington, Do Go

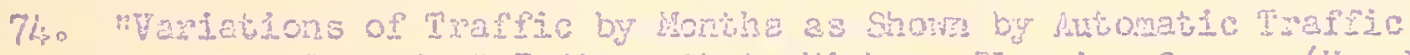

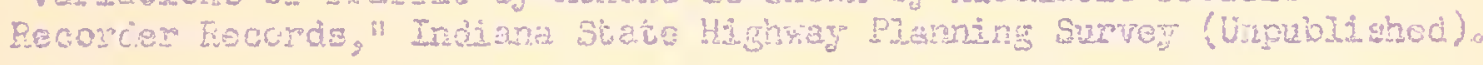

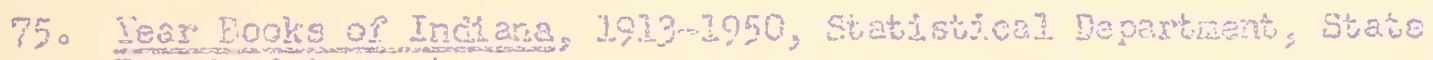

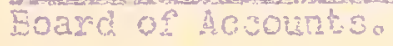


